\author{
Valeria Ruoppolo
}

\title{
Patologia Comparada de Cetáceos e Pinípedes
}

São Paulo

- 2003 - 


\section{Valeria Ruoppolo}

\section{Patologia Comparada de Cetáceos e Pinípedes}

Dissertação apresentada para obtenção do título de Mestre junto à Faculdade de Medicina Veterinária e Zootecnia da Universidade de São Paulo.

Departamento:

Patologia

Área de concentração:

Patologia Experimental e Comparada

Orientador:

Prof. Dr. José Luiz Catão-Dias

São Paulo

- 2003 - 
Autorizo a reprodução parcial ou total desta obra, para fins acadêmicos, desde que citada a fonte.

DADOS INTERNACIONAIS DE CATALOGAÇÃO-NA-PUBLICAÇÃO

(Biblioteca da Faculdade de Medicina Veterinária e Zootecnia da Universidade de São Paulo)

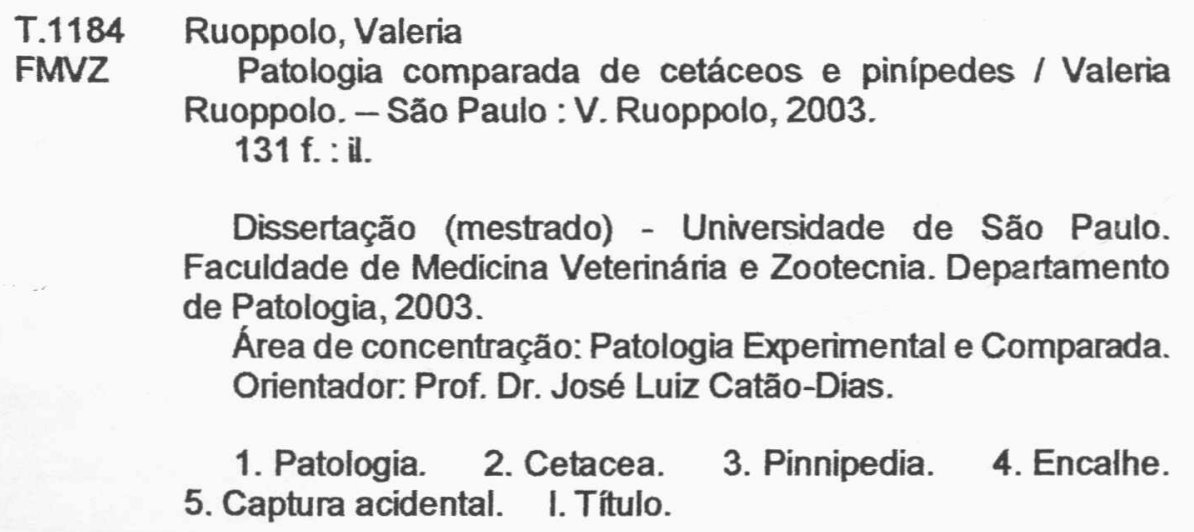

Dissertação (mestrado) - Universidade de São Paulo. Faculdade de Medicina Veterinária e Zootecnia. Departamento de Patologia, 2003.

Área de concentração: Patologia Experimental e Comparada. Orientador: Prof. Dr. José Luiz Catão-Dias.
1. Patologia. 2. Cetacea.
3. Pinnipedia.
4. Encalhe.

5. Captura acidental. I. Título. 


\section{FOLHA DE APROVAÇÃO}

Nome do autor: RUOPPOLO, Valeria

Título: Patologia comparada de cetáceos e pinipedes

Dissertação apresentada à Faculdade de Medicina Veterinária e Zootecnia da Universidade de São Paulo para obtenção do título de Mestre em Patologia

Aprovado em: $04,04,03$

\section{Banca Examinadora}

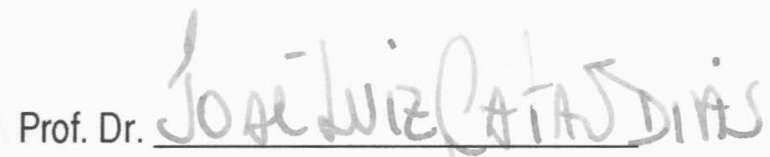

Julgamento: $\mathrm{ApROVHCA}$

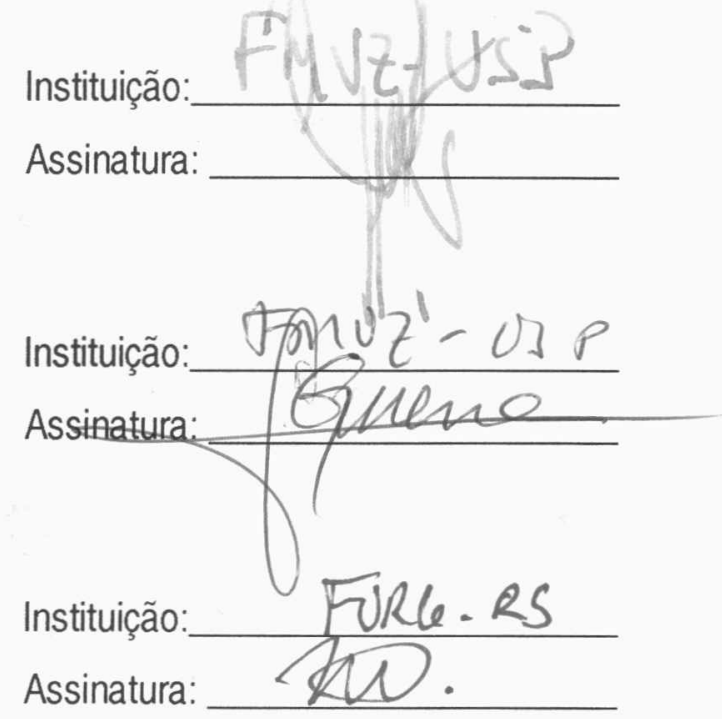

Prof. Dr. Mrâice Muellet Julgamento: APROUADA Assinatura: 
Toda a minha dedicação e amor à possibilidade de, com o meu trabalho, melhorar a saúde dos animais. 


\section{AGRADECIMENTOS}

Ao nosso sábio e mais querido orientador Prof. Dr. José Luiz Catão-Dias o meu mais profundo reconhecimento pela orientação, confiança, compreensão, paciência, amizade, estímulo e críticas sempre construtivas. Seu exemplo de dignidade e serenidade sempre foram motivo para nossa admiração. Obrigada por aceitar o desafio.

A toda minha pequena família, especialmente à minha mãe, La Teresa Bosch, por ter apoiado incansavelmente minhas decisões. Aos meus tios/padrinhos agradeço a possibilidade que me deram de estudar e de ser alguém hoje, por mais que eu tenha escolhido começar "atirando sardinhas"...

A Juliana Marigo, Carolina Bertozzi e Julio Reynoso, meus anjos que caíram do céu. Sem a doçura de vocês todo este caminho teria parecido muito árduo. Obrigada por estarem sempre presentes com palavras amigas, ombros e ouvidos. Obrigada por permitirem que eu cresça ao seu lado. Dju e Carol, tem muié que é ômi, e a gente vai lo0000000000000000onge!!

Agradeço a todos os grupos de estudo e pesquisadores que enviaram amostras e despenderam seu tempo, sem os quais não teria sido possivel a realização deste trabalho e 0 desenvolvimento do banco de tecidos: Laboratório de Mamíferos Marinhos MORG - FURG (Eduardo Secchi, Manuela Bassoi, Luciano Dalla Rosa, Dra. Mônica Muelbert); Centro de Recuperação de Animais Marinhos (CRAM-MORG/FURG) (Rodolfo P. "Neneco" da Silva e Andréa Adornes, obrigada pela dedicação na colheita e ainda por terem "vestido a camisa"!); Grupo de Estudos de Mamíferos Aquáticos do Rio Grande do Sul (GEMARS CECLIMAR/UFRGS) (agradeço a todos, especialmente depois do empurrãozinho do $\lg .$. ); Projeto Atlantis, IB-USP (Marcos César de O. Santos); Centro de Estudos de Encalhes de Mamíferos Marinhos (CEEMAM); Aquário Municipal de Santos (Andréa Maranho); FUNDAMAR (Shirley Pacheco de Souza); Projeto BioPesca (a todas nós!! Inclusive a Érica Barbosa e a Janaína Ribeiro); Fundação Parque Zoológico de São Paulo (Dr. Marcelo Vaz Guimarães e Dr. Daniel L. Fedullo); Centro de Estudos do Mar (CEM-UFPR) e IPeC (Dr. Fernando C. W. Rosas e Márcia Regina de Oliveira); Museu de Zoologia da USP (Alessandra Higa e Dr. Mário Rollo Jr.); Centro Golfinho Rotador (José Martins da Silva Jr.); Universidad Nacional de Mar del Plata CONICET/Argentina (Dr. Ricardo Bastida e Laura Rivero); Projeto MAQUA - UERJ; Aquário de Ubatuba (Renato Velloso da Silveira);

Aos colegas e companheiros de todas as horas do VPT: Emerson Mota, Marcelo Bittencourt Contieri e "Katiola" Kimura ("Os resistentes da Pato!!" Obrigada pelo companheirismo, discussões e ensinamentos); Flávia Regina Miranda (a estagiária mais eficiente que o grupo de 
"silvestress" teve durante o tempo que passei no LAPCOM!!); Ana Paula Garate (obrigada pelos cortes feitos no criostato); Sílvia Nery Godoy (obrigada pela foto dos ovários policísticos); Sabrina Epiphanio; Luciana Neves Torres; Cris Myiaji Kolesnikovas; Ana "Titi" Vianna; "Tita" Freiberger (obrigada pela companhia e todos os ensinamentos na Antártica); Lílian Sá; Cláudia "Berimbau" do Nascimento (VRA- obrigada pela colheita de material em FN, e ainda pela força sempre!!). E da Dju não preciso nem falar...

Aos funcionários do Laboratório de Histopatologia do VPT: Cláudio Arroyo, Luciano Antas Bugalho e Marguiti Isaura Soares da Silva pelo processamento das amostras e paciência nos momentos de "emergência".

Aos técnicos Raimundo Nonato Maciel e Edson Luiz de Souza pela ajuda durante as necrópsias realizadas no VPT e encaminhamento das carcaças ao motorista do Museu de Zoologia da USP. Obrigada também à D. Romeika Fabrício do Nascimento.

Ao chefe do Departamento Prof. Dr. Benjamin Eurico Malucelli e a todos os professores do VPT, em especial ao Dr. Guerra por ter me dado o meu primeiro estágio na USP (em 94!!), obrigada por me mostrar a beleza da Patologia.

À Ariela Setzer e Carlos Zago pelo corte e ajuda na leitura das primeiras amostras que ingressaram ao RPC. Ao Marco Aurélio Gattamorta pelo processamento dos cultivos microbiológicos e à Juliana Marigo pela identificação dos parasitos. À Nathalia Saito pela ajuda com as amostras do Banco de Tecidos e com a guerra contra as tabelas do Excel.

À Fernanda Marvulo do VPS pela disposição em testar a amostra na busca de Brucella.

Ao Marcos César de O. Santos pela ajuda no rascunho do projeto.

Ao Dr. Ricardo Bastida por haver dado minha primeira chance como profissional.

À Fundación Mundo Marino e "Pappo" Rodriguez Heredia pela amizade e coração de manteiga. À Viviana Quse e Laura Rivero pelos ensinamentos durante as todas as necrópsias realizadas no meu período na Argentina. Obrigada pela amizade de sempre.

A Fundação de Apoio à Pesquisa do Estado de São Paulo (FAPESP) pelo apoio financeiro indispensável ao projeto (processo 99/12335-8). 


\section{RESUMO}

RUOPPOLO, V. Patologia comparada de cetáceos e pinípedes. [Comparative pathology of cetaceans and pinnipeds]. 2003. 131f. Dissertação (Mestrado em Patologia Experimental e Comparada) - Faculdade de Medicina Veterinária e Zootecnia, Universidade de São Paulo, São Paulo, 2003.

O conhecimento das causas de morbidade e mortalidade dos mamíferos aquáticos pertencentes à ordem Cetacea e subordem Pinnipedia no Brasil é escasso. Este trabalho teve por objetivo caracterizar as principais causas que contribuem para a morte destes animais, incluindo dentre outras as enfermidades infecciosas, parasitárias, traumáticas, metabólicas e nutricionais. Foram analisadas amostras provenientes de necropsias de 110 indivíduos oriundos de encalhes naturais e capturas acidentais em redes de pesca ocorridos na costa sul e sudeste do Brasil. Ocasionalmente, amostras de cetáceos e pinípedes provenientes de centros de reabilitação, zoológicos, aquários e oceanários também foram analisadas. As amostras consistiram de fragmentos de 1 a $2 \mathrm{~cm}^{3}$ dos órgãos principais acondicionados em formalina a 10\%. As afecções foram diagnosticadas através de exames anatomopatológicos, associados, quando possível a resultados microbiológicos e parasitológicos. Dos diagnósticos finais elucidados para os cetáceos $88,6 \%$ (70/79) tiveram a morte relacionada com o sistema respiratório, 3,8\% (3/79) de origem metabólica, 2,5\% (2/79) de etiologia infecciosa, 1,3\% (1/79) com origem traumática antropogênica e em 3,8\% (3/79) foi indeterminada. Nos pinípedes as causas de morte também estiveram relacionadas principalmente com 0 trato respiratório $(48,5 \%-15 / 31)$. A morte decorrente de outras causas incluiu: $29,1 \%$ (9/31) de causas metabólicas; 3,2\% (1/31) nutricional; 3,2\% (1/31) digestivo; 3,2\% (1/31) urinário; 3,2\% (1/31) físico; 3,2\% (1/31) síndrome, colapso; $3,2 \%$ (1/31) vandalismo; 3,2\% (1/31) indeterminado. A análise parasitológica foi realizada em $15,4 \%$ (17/110) dos casos e a bacteriologia em 10,9\% (12/110) dos casos. As interpretações anatomopatológicas foram associadas aos demais resultados, quando presentes, e então analisados conforme informações recentes de literatura relativas ao assunto. As amostras utilizadas na realização deste projeto complementam o banco de tecidos de animais selvagens mantido pelo Laboratório de Patologia Comparada de Animais Selvagens da FMVZ, formando dessa forma o primeiro acervo de tecidos de mamíferos marinhos disponível no Brasil. Os resultados alcançados neste estudo reforçam a necessidade da abordagem multidisciplinar dos animais encalhados e também dos capturados acidentalmente em redes de pesca, buscando informações que possam colaborar para uma maior compreensão dos processos patológicos que os acometem e os predispõe à morte.

Palavras-chave: Cetacea. Pinnipedia. Patologia. Encalhe. Captura acidental. 


\begin{abstract}
RUOPPOLO, V. Comparative pathology of cetaceans and pinnipeds. [Patologia comparada de cetáceos e pinípedes]. 2003. 131f. Dissertação (Mestrado em Patologia Experimental e Comparada) - Faculdade de Medicina Veterinária e Zootecnia, Universidade de São Paulo, São Paulo, 2003.

The known causes of morbidity and mortality of aquatic mammals belonging to the Order Cetacea and Suborder Pinnipedia in Brazil is limited. The aim of this work was to characterize the main processes that contribute to or cause the death of these animals, and included investigating infectious, parasitic, traumatic, metabolic and nutritional diseases. Samples coming from 110 fresh animals were analyzed, including individuals from strandings and incidentally caught in fishing nets along the south and southeastern coasts of Brazil. Circumstantially, carcasses coming from zoological collections, aquariums and rehabilitation centers were also included. The samples consisted of fragments of $1-2 \mathrm{~cm}^{3}$ taken of the main organs and fixed in $10 \%$ formalin. All the tissues have been processed according to routine histological procedures and analyzed under light microscopy. Diseases were diagnosed through anatomopathologic examinations, associated, whenever possible, with microbiologic and parasitologic results and then compared to related bibliography. Final results, mentioning the cause of the death, included: cetaceans: $88,6 \%$ (70/79) had lesions associated with the respiratory tract; $3,8 \%(3 / 79)$ of metabolic origin, $2,5 \%$ (2/79) of infectious etiology, 1,3\% (1/79) were human related injuries, and $3,8 \%(3 / 79)$ of the cases were undetermined. For the pinnipeds the main cause of death was also related to the respiratory tract $(48,5 \%$ - 15/31). The causes of death implicated in the other cases included: 29,1\% (9/31) metabolical causes; 3,2\% (1/31) nutritional origin; 3,2\% (1/31) digestive causes; $3,2 \%$ (1/31) urinary tract; 3,2\% (1/31) physical causes; 3,2\% (1/31) syndrome; 3,2\% (1/31) human related injuries; $3,2 \%$ (1/31) were undetermined. Parasitological analyses were performed in $15,4 \%(17 / 110)$ of the cases and bacteriology in 10,9\% (12/110). The samples utilized in this project were stored to create a tissue bank for further studies. The results achieved in this work reinforce the need for a multidisciplinary view of stranded and by-caught animals, searching for information that can collaborate to better understand the pathologic processes affecting marine mammals and predisposing their death.
\end{abstract}

Key words: Cetacea. Pinnipedia. Pathology. Stranding. By-catch. 


\section{LISTA DE FIGURAS}

Figura 1. Animal disposto para a necróspia no VPT. Stenella frontalis - Caso No. 46. 66

Figura 2. Lesões cortantes provocadas pelo enrredamento. Stenella frontalis - Caso No. 47 66

Figura 3. Animal disposto para a necróspia no VPT. Observar as marcas de rede no rostro, cabeça, e cicatriz no centro do melão. Observa-se ainda opacidade no cristalino. Pontoporia blainvillei - Caso No. 98.

Figura 4. Pulmão de aspecto marmorizado, apresentando enfisema, edema e congestão.

Pneumonia aspirativa. Arctocephalus tropicalis - Caso No. 107.

Figura 5. Cistos ovarianos. Pontoporia blainvillei - Caso №. 34 66

Figura 6. Nefromegalia de aspecto nodular cístico in situ. Nota-se ainda a glândula supra-renal, o baço e baços acessórios. Steno bredanensis - Caso No. 38.

Figura 7. Detalhe do rim policístico. Observar a pouca quantidade de parênquima funcional. Steno bredanensis - Caso No. 38.

Figura 8. Formações cutâneas verrucosas na comissura labial. Steno bredanensis - Caso No. 38

Figura 9. Corte histológico da formação ilustrada na Figura 8. Notar a estrutura característica de lesão papilomatosa. Steno bredanensis - Caso No. 38 (H.E., 40x).

Figura 10. Pênis, notar formações cutâneas nodulares. Material fixado em formalina 10\%. Tursiops truncatus - Caso №. 7

Figura 11. Pênis, visão microscópica das formações cutâneas ilustradas na Figura 10. Observar hiperplasia de tecido linfóide (seta). Tursiops truncatus - Caso No. 7 (H.E., 40x).

Figura 12. Pulmão, abscedação. Tursiops truncatus - Caso No. 7. .70

Figuras 13a e b. Detalhes do corte apresentado na Figura 12, notar parasita nematóide no centro do abscesso. Tursiops truncatus - Caso No. 7 (H.E., 20 e 100x).

Figura 14. Pulmão, notar alterações comumente encontradas nos casos de captura acidental: congestão (1) e edema (2). Pontoporia blainvillei - Caso No. 34 (H.E., 100x)...

Figura 15. Pulmão, detalhe da Figura 14. Congestão (1) e edema (2). Pontoporia blainvillei Caso No. 34 (H.E., 200x).

Figura 16. Fígado, observar local de perfuração do objeto contundente, notar fibroplasia. Pontoporia blainvillei - Caso No. 98 (Tricrômico de Masson, 20x)..... 
Figura 17. Fígado, detalhe da Figura 16. Pontoporia blainvillei - Caso No. 98 (Tricrômico de Masson, 40x)......

Figura 18. Fígado, mesma região ilustrada nas Figuras 16 e 17, positiva para hemossiderose. Pontoporia blainvillei - Caso No. 98 (Perls, 40x).

Figura 19. Fígado, notar hiperplasia ductal exuberante. Pontoporia blainvillei Caso No. 98 (H.E., 40x)

Figura 20. Pulmão, pneumonia, intersticial, crônica, difusa, severa com calcificação distrófica (seta) e carneificação do parênquima (1). Otaria flavescens Caso No. 44 (H.E., 40x).

Figura 21. Pulmão, detalhe da Figura 20. Confirmação da fibroplasia. Otaria flavescens -

Caso No. 44 (Tricrômico de Masson, 100x).

Figura 22. Notar fibrose cardíaca. Arctocephalus tropicalis - Caso №. 107.

Figura 23. Coração, coloração positiva para fibroplasia. Arctocephalus tropicalis Caso No. 107 (Tricrômico de Masson, 20x).

Figura 24. Pulmão, pneumonia aspirativa. Observar material particulado nos espaços aéreos (seta). Pontoporia blainvillei - Caso No. 48 (H.E., 100x)

Figura 25. Pulmão, detalhe da Figura 24. Observar material particulado nos espaços aéreos (seta). Pontoporia blainvillei - Caso No. 48 (H.E., 400x).

Figura 26. Pulmão, broncopneumonia, purulenta, difusa, moderada a severa.

Notar grande quantidade de eosinófilos (seta). Sotalia fluviatilis -

Caso No. 43 (H.E., 100x)

Figura 27. Pulmão, notar Metastrongilidae no espaço alveolar. Sotalia fluviatilis Caso No. 8 (H.E., 40x).

Figura 28. Linfonodo, linfadenite, eosinofílica, difusa, moderada a severa. Notar recrutamento maciço de eosinófilos em direção ao pulmão (setas).

Sotalia fluviatilis - Caso No. 43 (H.E., 40x)

Figura 29. Detalhe indicado na Figura 28. Linfonodo, observar grande quantidade de eosinófilos (setas). Sotalia fluviatilis - Caso No. 43 (H.E., 100x).

Figura 30. Metastrongilidae e larvas no parênquima pulmonar. Arctocephalus australis Caso No. 82 (H.E., 40x) .76

Figura 31. Detalhe indicado na Figura 30. Arctocephalus australis - Caso No. 82 (H.E., 200x)... .76

Figura 32. Pulmão, vista geral do órgão apresentando pneumonia, crônica, granulomatosa induzida por cristais de colesterol. Notar pleuropneumonia, crônica, difusa.

Pontoporia blainvillei - Caso No. 98 (H.E., 20x) 
Figura 33. Pulmão, pneumonia, crônica, granulomatosa induzida por cristais de colesterol. Notar formação de células gigantes (seta) Pontoporia blainvillei - Caso No. 98 (H.E., 100x)

Figuras 34a e b. Fígado, observar degeneração macro e microgoticular severa.

Pontoporia blaivillei - Caso No. 90 (H.E., 100 e 200x).

Figuras 35a e b. Fígado, confirmação do acúmulo de lipídios. Pontoporia blaivillei -

Caso No. 90 (Sudan Black, 40 e 100x).

Figuras 36a e b. Rim, observar acúmulo de lipídios no túbulos contorcidos proximais.

Stenella longirostris - Caso No. 27 (H.E., 40 e 400x).

Figuras 37a e b. Rim, confirmação do acúmulo de lipídios. Stenella longirostris - Caso No. 27

(Sudan Black, 40 e 200x)

Figura 38. Baço, esplenite, parasitária. Notar ovos de parasitas trematóides (setas)

e a formação de células gigantes. Steno bredanensis - Caso No. 38 (H.E., 200x).

Figura 39. Medula cervical, meningomielite, etiologia indeterminada. Observar a grande quantidade de células mononucleares (seta). Stenella clymene Caso No. 88 (H.E., 100x). .78

Figura 40. Retirada do encéfalo através de pequena janela feita na região posterior do crânio. Pontoporia blainvillei..

Figura 41. Baço, hiperplasia linfóide reativa. Stenella clymene - Caso No. 88 (H.E., 40x).

Figura 42. Rim, glomerulonefrite membranosa. Notar espessamento da membrana do tufo glomerular. Arctocephalus tropicalis - Caso No. 20 (H.E., 200x).

Figura 43. Rim, constatação da glomerulonefrite membranosa. Arctocephalus tropicalis Caso No. 20 (PAS, 200x). 80

Figura 44. Intestino, microabscessos criptais. Pontoporia blainvillei - Caso No. 48 (H.E., 100 x).........80

Figura 45. Intestino, detalhe da Figura 44. Pontoporia blainvillei - Caso No. 48 (H.E., 400 x)..... 80

Figura 46. Pulmão, vasculite fibrinóide. Pontoporia blainvillei - Caso No. 34 (H.E., 200x)... .80

Figura 47. Baço, esplenite, aguda, moderada.Notar linfocitólise centro-folicular. Arctocephalus tropicalis - Caso No. 55 (H.E., 40x). 


\section{LISTA DE GRÁFICOS}

Gráfico 1. Representação dos diagnósticos finais principais que determinaram as causas de morte que afetaram cetáceos, dispostos de acordo com a sistematização proposta por Montali (1991), apresentada no ANEXO II. Sudeste e sul do Brasil, 1997 - 2002

Gráfico 2. Representação dos diagnósticos finais principais que determinaram as causas de morte que afetaram pinípedes, dispostos de acordo com a sistematização proposta por Montali (1991), apresentada no ANEXO II.

Sudeste e sul do Brasil, 1997 - 2002. . .45 


\section{LISTA DE TABELAS}

Tabela 1. Correlação das várias identificações empregadas ao material disponível em função da espécie, origem e cadastramento junto aos Laboratórios de Patologia Comparada de Animais Silvestres e de Histologia, indexados pelo "Caso No.". Sudeste e sul do Brasil, 1997 - 2002.

Tabela 2. Distribuição das principais alterações macroscópicas observadas em cetáceos e pinípedes necropsiados junto ao LAPCOM e por terceiros $\left(^{*}\right)$, em função do Caso No. Sudeste e sul do Brasil, 1997 - 2002.

Tabela 3. Distribuição dos caracteres individuais, exames laboratoriais realizados, diagnósticos morfológicos principais e causas de morte observados em cetáceos em função do Caso No. Sudeste e sul do Brasil, 1997 - 2002.

Tabela 4. Distribuição dos caracteres individuais, exames laboratoriais realizados, diagnósticos morfológicos principais e causas de morte observados em pinípedes em função do Caso No. Sudeste e sul do Brasil, 1997 - 2002

Tabela 5. Distribuição dos cetáceos analisados histologicamente, dispostos a partir da espécie e número de animais analisados. Sudeste e sul do Brasil, 1997 $-2002$.

Tabela 6. Distribuição dos pinípedes analisados histologicamente, dispostos a partir da espécie e número de animais analisados. Sudeste e sul do Brasil, 1997 - 2002

Tabela 7. Distribuição dos resultados de exames microbiológicos realizados em cetáceos e pinípedes necropsiados junto ao LAPCOM e por terceiros, em função do Caso No. Sudeste do Brasil, 1997 - 2002.

Tabela 8. Distribuição dos animais submetidos à análise parasitológica, dispostos a partir da espécie e número de animais analisados. Sudeste do Brasil, 1997 - 2002.

Tabela 9. Distribuição dos resultados parasitológicos observados em órgãos de cetáceos e pinípede analisados pela pós-graduanda Juliana Marigo, em função do Caso No. e da espécie animal. Sudeste do Brasil, 1997 - 2002.

Tabela 10. Correlação dos casos da espécie Pontoporia blainvillei que apresentaram quadros mórbidos anteriores à morte por captura acidental, distribuídos pelo Caso No. e afecção encontrada. Sudeste e sul do Brasil, 1997 - 2002. 


\section{LISTA DE ESPÉCIES E NOMES POPULARES}

As espécies foram classificadas de acordo com IBAMA (2001) e Jefferson (1993).

Cetácea

Balaenoptera acutorostrata: baleia-minke-anã

Delphinapterus leucas: beluga

Delphinus capensis: golfinho-comum-de-bico-longo

Eubalaena australis: baleia-franca-do-sul

Kogia breviceps: cachalote-pigmeu

Kogia simus: cachalote-anão

Megaptera novaeangliae: jubarte

Phocoena phocoena: boto-do-porto, marsopa-do-porto

Physeter macrocephalus: cachalote

Pontoporia blainvillei: franciscana, toninha

Sotalia fluviatilis: boto-cinza, tucuxi

Stenella clymene: golfinho-de-climene

Stenella coeruleoalba: golfinho-estriado, golfinho-listrado

Stenella frontalis: golfinho-pintado-do-atlântico

Stenella longirostris: golfinho-rotador

Steno bredanensis: golfinho-de-dentes-rugosos

Tursiops truncatus: golfinho-nariz-de-garrafa

\section{Pinnipedia}

Arctocephalus australis: lobo-marinho-do-sul

Arctocephalus tropicalis: lobo-marinho-subantártico

Arctocephalus gazella: lobo-marinho-antártico

Callorhinus ursinus: lobo-marinho-do-norte

Eumetopias jubatus: leão-marinho-de-Steller

Erignathus barbatus: foca-barbada

Hydrurga leptonyx: foca-leopardo

Leptonychotes weddellii: foca-de-weddell

Lobodon carcinophagus: foca-caranguejeira

Otaria flavescens: leão-marinho-do-sul

Phoca hispida: foca-anelada

Phoca vitulina: foca-do-porto

Zalophus californianus: leão-marinho-da-califórnia 


\section{SUMÁRIO}

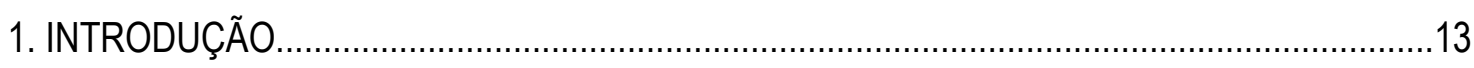

2. OBJETIVOS

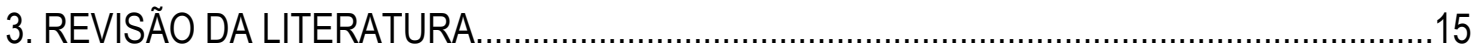

3.1 Aspectos da História Natural de Cetáceos e Pinípedes.....................................................15

3.2 Aspectos anatômicos macro e microscópicos de cetáceos e pinípedes...............................17

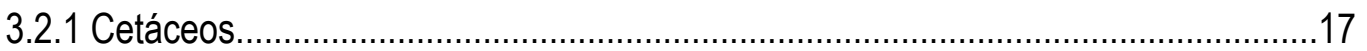

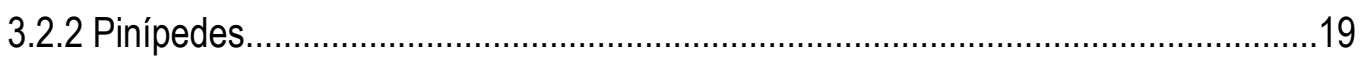

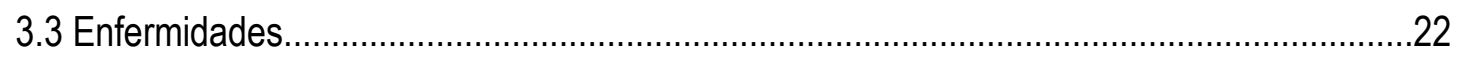

3.3.1 Enfermidades infecciosas ou infecto-parasitárias.................................................22

3.3.1.1 Enfermidades bacterianas.................................................................. 22

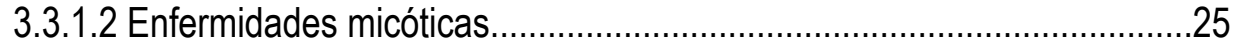

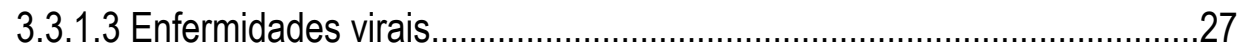

3.3.1.4 Enfermidades parasitárias..................................................................29

3.3.2 Doenças metabólicas, tóxicas e neoplásicas.......................................................30

3.3.3 Outras causas de mortalidade............................................................................

4. MATERIAL E MÉTODO

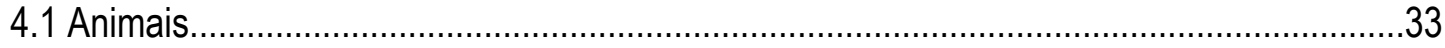

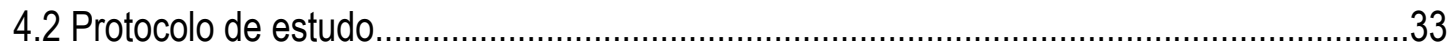

4.2.1 Informações clínicas e de manejo..........................................................................33

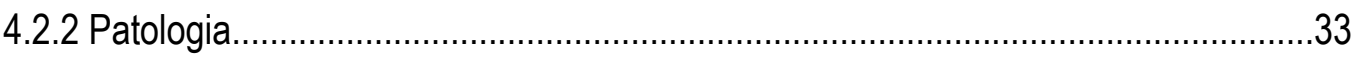

4.2.2.1 Análise necroscópica.........................................................................33

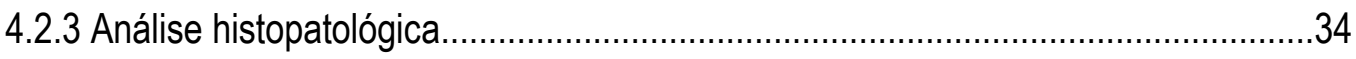

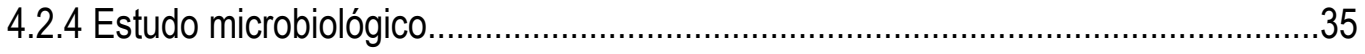

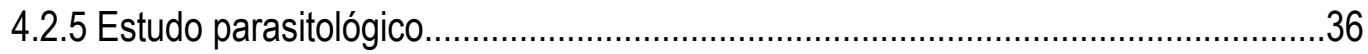

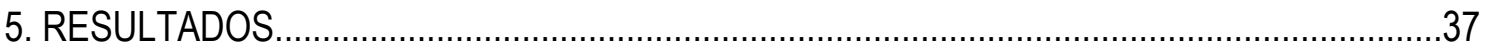

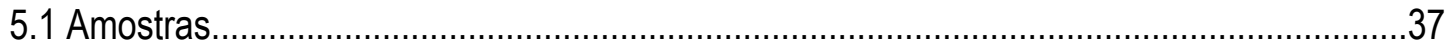

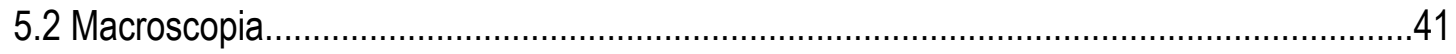

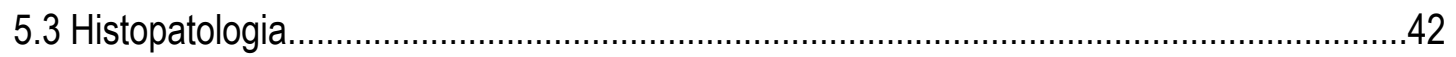

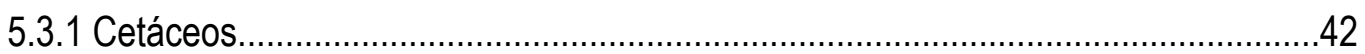

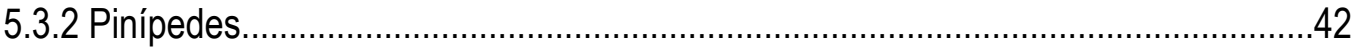


5.4 Causas de morte

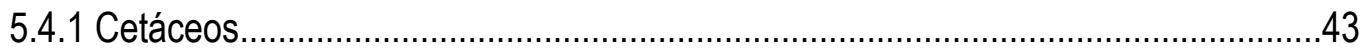

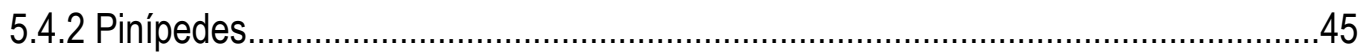

5.5

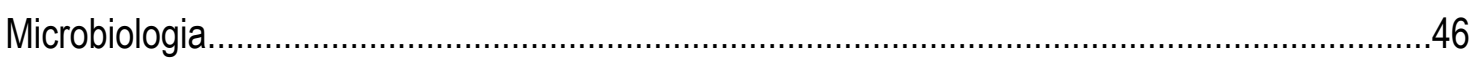

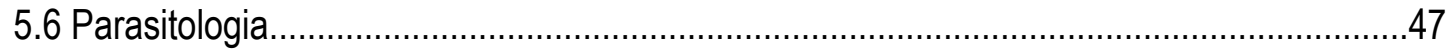

6. DISCUSSÃO

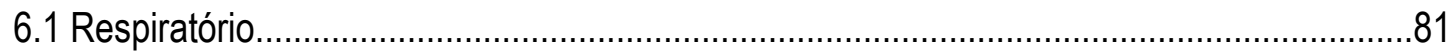

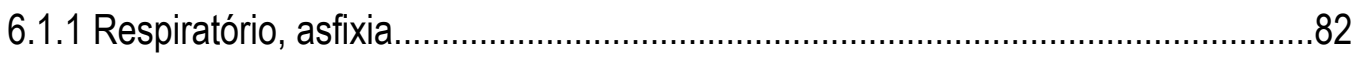

6.1.2 Morte em decorrência de outras afeç̧ões respiratórias........................................87

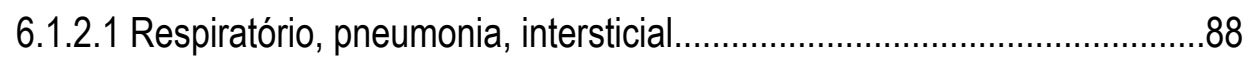

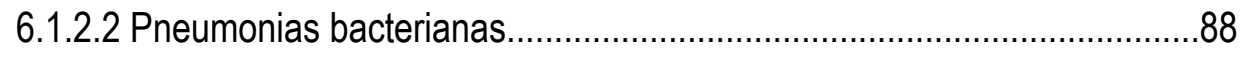

6.1.2.3 Respiratório, pneumonia aspirativa....................................................91

6.1.2.4 Respiratório, pneumonia, parasitária....................................................91

6.1.3 Outros achados no sistema respiratório...............................................................95

6.1.3.1 Pneumonia, crônica, granulomatosa induzida pela presença de corpo estranho - cristais de colesterol........................................................................95

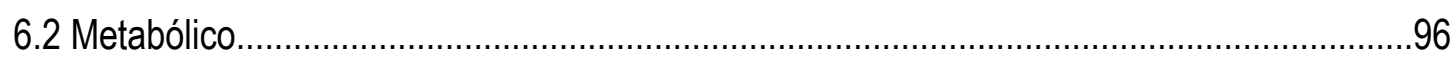

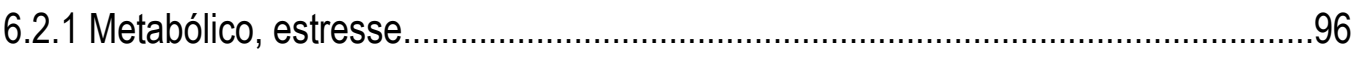

6.2.2 Metabólico, lipidose hepato-renal.....................................................................98

6.3 Infeccioso

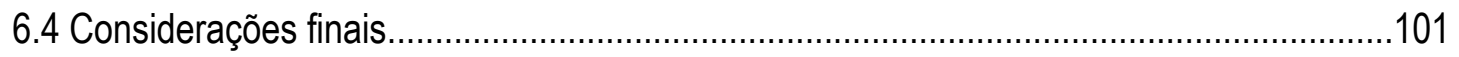

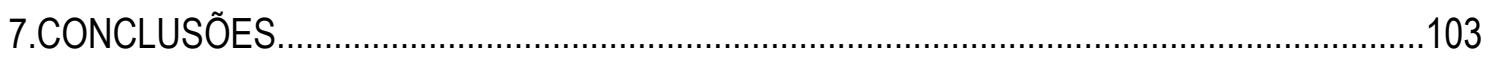

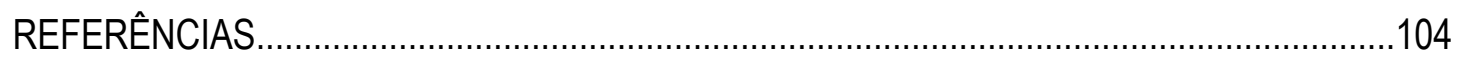

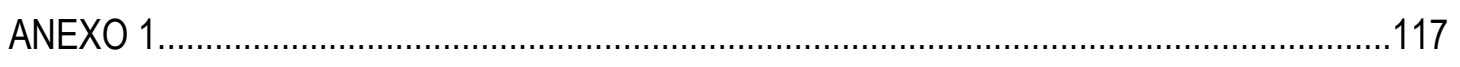

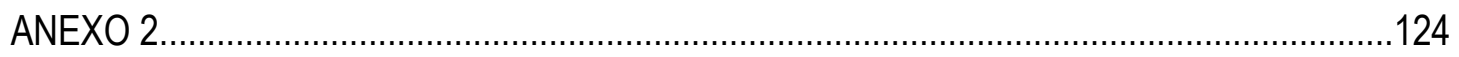

ANEXO 3 


\section{INTRODUÇÃO}

A pesquisa com mamíferos aquáticos no Brasil é recente, datando os primeiros estudos sistematizados do final da década de 70 . Atualmente, a comunidade científica que se dedica à pesquisa e à conservação desses animais é composta por cerca de 150 a 200 pesquisadores, sendo a grande maioria formada por profissionais da área de Ciências Biológicas e Oceanografia. É praticamente inexistente a literatura e a investigação sobre quais as afecções que acometem estes animais na costa brasileira. A limitação destes trabalhos decorre principalmente devido à escassez de profissionais especializados no estudo de enfermidades nestes mamíferos.

O Brasil possui cerca de 7500 km de costa, onde 43 espécies de cetáceos e 7 de pinípedes já foram notificadas em águas continentais e costeiras (IBAMA, 2001; PINEDO et al., 2002).

Sem o conhecimento das causas de mortalidade que acometem os mamíferos aquáticos, bem como os principais fatores de impacto sobre as populações naturais, não é possível traçar planos de conservação para as diferentes espécies. Cumpre ressaltar que a identificação das causas de mortalidade, considerando sua quantificação e seu monitoramento, faz parte dos itens G.2 e G.4 das listas de projetos prioritários inseridas nos Planos de Ação para os mamíferos aquáticos em águas brasileiras (IBAMA, 1997 e 2001). 


\section{OBJETIVOS}

Foram objetivos do presente trabalho a determinação das principais causas de morte, assim como das mais significativas enfermidades acometendo cetáceos e pinípedes comuns nas costas sul e sudeste do Brasil. Para tanto utilizaram-se resultados necroscópicos e histopatológicos e, na disponibilidade de material biológico adequado, microbiológicos e parasitológicos. Pretendeu-se, desta forma, contribuir tanto para a conservação destas espécies de mamíferos, assim como para o corpo de informação existente na área de patologia comparada de animais selvagens. 


\section{REVISÃO DA LITERATURA}

\subsection{Aspectos da História Natural de Cetáceos e Pinípedes}

A teoria do desenvolvimento evolucionário dos mamíferos aquáticos possui controvérsias, porém é sabido que se originam de um ou mais mamíferos terrestres (BARNES et al., 1985; GINGERICH et al., 2001).

Segundo Barnes et al., (1985) os cetáceos, ordem que agrupa as baleias e os golfinhos, estão relacionados aos ungulados, como os eqüinos e os ruminantes. Gingerich e colaboradores (2001) também afirmaram que os cetáceos evoluíram a partir de artiodáctilos. A ordem Cetacea está composta por 79 espécies e é dividida em duas subordens, de acordo com Jefferson et al., (1993) e Reyes et al., (1995):

- Subordem Mysticeti (11 espécies): inclui os rorquais ou baleias verdadeiras, que apresentam como característica principal uma série de placas queratinizadas localizadas no interior da boca, denominadas barbatanas. Estas estão posicionadas paralelamente aos dois lados da maxila e possuem pequenas cerdas nas extremidades com função de retenção do alimento. Os representantes desta subordem possuem dois orificios respiratórios. Podem atingir entre seis e 32 metros de comprimento na idade adulta.

- Subordem Odontoceti (68 espécies): inclui os cetáceos com dentes para a apreensão do alimento, como os golfinhos em geral, as orcas e os cachalotes. Os odontocetos possuem um orifício respiratório apenas, não necessariamente na linha mediana dorsal. Podem atingir entre um e 18 metros na idade adulta. 
$\mathrm{Na}$ Ordem Carnivora são representadas outras espécies de mamíferos aquáticos. Nesta ordem, a subordem Pinnipedia, composta por 34 espécies, possui ancestrais em comum com o cão e está dividida em três famílias, de acordo com Barnes et al., (1985) e Jefferson et al., (1993):

- Superfamília Otaroidea:

- Família Odobenidae (uma espécie): inclui as morsas, cuja distribuição é restrita ao Ártico;

- Família Otariidae (14 espécies): inclui os pinípedes que possuem orelhas, conhecidos como lobos e leões-marinhos.

- Superfamília Phocoidea:

- Família Phocidae (19 espécies): inclui os pinípedes que não possuem orelhas, que são as focas em geral e os elefantes-marinhos.

Os pinípedes são carnívoros aquáticos extremamente especializados que podem ser encontrados desde os pólos até os trópicos. Um fator unificador do grupo é que todos passam a maior parte do tempo na água, porém necessitam retornar a um substrato sólido, como a terra ou o gelo, para parir e, em sua maioria, copular (JEFFERSON et al., 1993).

Fatos sobre a biologia, tanto de cetáceos quanto de pinípedes, possuem amplas variações entre as espécies e mesmo entre grupos de diferentes regiões geográficas. Alguns fatores como a idade de maturidade sexual, período de lactação e intervalo entre crias são influenciados por fatores externos como a densidade populacional e a disponibilidade de alimento (GERACl; LOUNSBURY, 1993a; b). Ainda, estes animais possuem diversas modificações anatômicas e fisiológicas relacionadas com as adaptações ao meio ambiente aquático (BRITT; HOWARD, 1983a; PABST et al., 1999). 


\subsection{Aspectos anatômicos macro e microscópicos de cetáceos e pinípedes}

\subsubsection{Cetáceos}

Este grupo é totalmente adaptado e dependente do meio aquático. Todos os cetáceos apresentam o corpo de formato longilíneo e fusiforme (GERACl; LOUNSBURY, 1993a). Para tanto, durante o processo de evolução houve o desaparecimento do pescoço devido ao encurtamento das vértebras cervicais, os membros anteriores encurtaram-se e transformaram-se em nadadeiras peitorais utilizadas para o direcionamento do nado, os membros posteriores regrediram e houve o aparecimento de uma nadadeira caudal constituída de tecido conjuntivo denso com função de propulsão. A nadadeira dorsal também é constituída de tecido conjuntivo denso e atua na estabilização do nado. Não possuem pavilhão auricular e o sistema genital e glândulas mamárias são intrabdominais (BRITT; HOWARD, 1983a; DIERAUF, 1990a; PABST et al., 1999).

O tegumento dos cetáceos apresenta diferenças marcantes, quando comparado ao dos animais terrestres. A pele é macia, impermeável e não possui glândulas, nem pêlos, com exceção das vibrissas presentes no rostro dos infantes. A epiderme é espessa e não queratinizada, sendo composta primariamente pela camada espinhosa e apresentando papilas profundas, possuindo uma camada granular a menos. A descamação contínua, devido ao atrito com a água, pode haver contribuído para a ausência do estrato córneo queratinizado. A camada basal exibe mitoses constantes (BRITT; HOWARD, 1983a; ROMMEL; LOWENSTINE, 2001).

O orifício respiratório encontra-se no topo da cabeça e as passagens nasais possuem uma série conectada de sacos aéreos envolvidos na produção do som. A laringe é uma estrutura altamente modificada, tubular e alongada que comunica a traquéia ao orifício respiratório. 0 arranjo da laringe permite a estas espécies engolir e respirar concomitantemente. Os pulmões são simétricos e não lobados, com pleura espessa, textura firme e "elástica" devido à presença de anéis cartilagíneos ao 
redor de brônquios e bronquíolos, prevenindo o colapso das vias aéreas do trato respiratório inferior, quando submetidas à pressão durante os mergulhos. Os septos alveolares contém dois capilares paralelos, com a função de incrementar a oxigenação do sangue e diminuir o tempo de recuperação após mergulhos profundos, pinípides e outros mamíferos possuem apenas um. Esfíncteres mioelásticos estão presentes nos bronquíolos terminais, presumivelmente como mais uma adaptação aos mergulhos (BRITT; HOWARD, 1983a; ROMMEL; LOWENSTINE, 2001).

Quanto ao sistema digestivo, a língua não apresenta papilas gustativas e o estômago possui três compartimentos. A primeira câmara é um prolongamento do esôfago, delineada por epitélio escamoso estratificado aglandular, com função de armazenamento. A segunda porção corresponde ao estômago fúndico, com glândulas secretórias de $\mathrm{HCl}$ e enzimas digestivas. $\mathrm{O}$ terceiro compartimento é secretor de muco e prepara o conteúdo para a digestão intestinal. Microscopicamente, os estômagos possuem aparência análoga ao das espécies terrestres, adicionando que as células parietais são bastante proeminentes nos odontocetos. Os intestinos são extremamente longos e não possuem distinção visível entre intestino delgado e grosso, pois o ceco está ausente na maioria dos cetáceos, com exceção de alguns misticetos. Histologicamente é numerosa a presença de tecido linfóide associado ao longo de todo o trajeto intestinal, especialmente no cólon distal (DIERAUF; GAGE, 1990; LOWENSTINE; OSBORN, 1990). O fígado geralmente é bilobado e não possui vesícula biliar. Possuem duto hepatopancreático (BRITT; HOWARD, 1983a; ROMMEL; LOWENSTINE, 2001).

A anatomia dos órgãos linfóides de Tursiops truncatus foi extensivamente descrita por Cowan e Smith (1999). Estes autores mencionam que os linfonodos constantes ocorrem em quatro grupos, baseado em sua localização e estrutura: somáticos, incluindo pélvicos e cervicais; associados ao pulmão, incluídos os nodos marginal, diafragmático e hilar; viscerais incluindo mesentéricos, pancreáticos, pericólicos e porta-hepáticos; e os linfonodos do arco aórtico. 
O baço é pequeno e firme, podendo estar acompanhado por pequenos baços acessórios. Possui formato esférico na maioria das espécies, com cápsula espessa, sendo esta fibrosa externamente e muscular internamente, com células musculares estendendo-se em trabéculas espessas (COWAN; SMITH, 1999).

O sistema urogenital possui os rins alongados e lobulados externamente, com diversas unidades individuais, ou reniculi. Cada reniculus possui seu próprio córtex, medula e papila, que compartilham um duto urinário comum, que leva ao ureter proximal. Os reniculi estão agrupados por uma fina cápsula fibrosa (MALUF; GASSMAN, 1998; ROMMEL; LOWENSTINE, 2001). A bexiga é geralmente pequena, de parede espessa e mantida quase sempre vazia. Os testículos são estruturas fusiformes e alongadas, posicionadas lateral ou ventralmente aos rins. Em algumas espécies podem atingir grandes proporções, alcançando até $8 \%$ do peso corporal. 0 pênis é fibroelástico, como na maioria dos artiodáctilos e apresenta flexura sigmóide, como observado nos ruminantes (PABST et al.,1999). O posicionamento e formato geral do trato reprodutivo feminino é similar ao dos mamíferos terrestres (BOYD et al., 1999; PABST et al., 1999). A diferenciação sexual é feita através das fendas genitais (GERACl; LOUNSBURY, 1993a).

\subsubsection{Pinípedes}

A pele da maioria dos pinípides é macia, com pêlos, pregas, bem pigmentada e queratinizada. Existe a presença de glândulas sudoríparas e apócrinas (ROMMEL; LOWENSTINE, 2001). A epiderme dos focídeos é mais espessa e menos queratinizada que a dos otarídeos, por esse motivo os otarídeos são menos tolerantes ao frio, sendo bastante dependentes da pelagem e da camada de gordura para a manutenção do calor (GERACl; LOUNSBURY, 1993b). Não há presença de músculos pilo-eretores em nenhuma das espécies e a mudança de anual pelo é bastante traumática para o focídeos, onde há a 
perda de grandes porções da epiderme juntamente com os pêlos (LOWENSTINE; OSBORN, 1990; ROMMEL; LOWENSTINE, 2001).

Riedmann (1990b) e Geraci e Lounsbury (1993b), sugerem que a diferenciação entre focídeos e otarídeos faz-se de acordo com as seguintes características:

- Focídeos deslocam-se em terra arqueando seus corpos, pois possuem as nadadeiras anteriores curtas, não utilizando-as como apoio. São muito mais graciosos na água, utilizando as nadadeiras posteriores, em movimentos alternados, para deslocar-se e as anteriores para direcionar o nado. No caso dos otarídeos, estes deslocam-se sobre os quatro membros com relativa rapidez e agilidade em terra. Na água utilizam as nadadeiras anteriores, em forma de remo, para impulsionar-se e utilizam as posteriores para direcionar-se.

- Focídeos possuem corpos fusiformes arredondados, pescoço curto e volumoso e não possuem pavilhões auriculares. As unhas estão localizadas nas nadadeiras anteriores. Otarídeos são mais delgados, possuem pescoços longos, pavilhões auriculares pequenos, porém proeminentes. Possuem as nadadeiras anteriores alongadas e com unhas rudimentares, sendo que os membros posteriores alojam as unhas com desenvolvimento normal.

Pinípedes possuem os pulmões divididos em lobos, apresentando dois no pulmão esquerdo e três no direito. Alguns indivíduos apresentam os anéis traqueais completos e em outros podem ser incompletos. Histologicamente, assim como nos cetáceos, há a presença de anéis cartilagíneos e esfícteres mioelásticos até os bronquíolos terminais, prevenindo o colabamento dos pulmões quando submetidos à pressão dos mergulhos. 0 tórax alongado posiciona o diafragma obliquamente (ROMMEL; LOWENSTINE, 2001; STEWARDSON et al., 1999).

A anatomia interna dos pinípedes é semelhante à maioria dos carnívoros. São monogástricos, apresentando intestino delgado longo e intestino grosso curto $(<35 \mathrm{~cm})$, separados por um ceco 
rudimentar e com grande quantidade de tecido linfóide associado ao cólon distal. O fígado é multilobado e o duto hepático une-se ao duto pancreático na parede do duodeno, possuindo vesícula biliar. O número de lobos e de fissuras pode variar, principalmente nos leões-marinhos, cujas profundas fissuras dão ao fígado uma aparência ondulada (DIERAUF; GAGE,1990; ROMMEL; LOWENSTINE, 2001).

Quanto ao sistema linfóide, os linfonodos estão organizados como nos canídeos, possuindo seio subcapsular periférico, regiões folicular, cortical e paracortical, cordões medulares e seios (ROMMEL; LOWENSTINE, 2001).

O baço é alongado, freqüentemente escuro, apresentando cápsula fibromuscular espessa, com trabéculas proeminentes, padrão sinusoidal similar ao dos canídeos e repleto de plasmócitos (ROMMEL; LOWENSTINE, 2001; STEWARDSON et al., 1999). Em pinípedes jovens é comum observar a presença de hemossiderose e hematopoiese extra-medular esplênicas (LOWENSTINE; OSBORN, 1990).

Quanto ao sistema urogenital, os rins são estruturas ovaladas, alongadas, com formato de feijão. São lobulados, portanto constituídos por inúmeras unidades individuais ou reniculi, como já descrito para os cetáceos. Os órgãos genitais seguem um padrão semelhante ao dos carnívoros terrestres. Machos de focídeos e odobenídeos apresentam os testículos na região ingüinal, alojados entre músculos abdominais internos e externos. Otarídeos possuem bolsa escrotal. No sistema genital feminino, o ânus e a vagina desembocam em uma "cloaca" comum anteroventral à base da cauda. Nesta mesma posição encontra-se o ânus nos machos, porém a diferenciação sexual é feita localizando-se a abertura peniana que se encontra a alguns centímetros da cicatriz umbilical (GERACl; LOUNSBURY, 1993b; ROMMEL; LOWENSTINE, 2001). 
Apesar do sistema circulatório dos mamíferos marinhos ser altamente modificado como uma adaptação aos mergulhos, estas mudanças são mais bem apreciadas macroscopicamente e não histologicamente (LOWENSTINE; OSBORN, 1990).

\subsection{Enfermidades}

Desde o início da medicina em mamíferos marinhos numerosos trabalhos foram realizados estudando as enfermidades de cetáceos e pinípedes, baseados em informações obtidas de animais em cativeiro, de encalhes e ainda de capturas acidentais em redes de pesca (GERACl; SWEENEY, 1979; GERBER, et al., 1993; MEDWAY, 1980; RIDGWAY, 1972; STROUD; ROFFE, 1979; SWEENEY 1974; SWEENEY; GILMARTIN, 1974; SWEENEY; RIDGWAY, 1975).

\subsubsection{Enfermidades infecciosas ou infecto-parasitárias}

Os cetáceos e os pinípedes são acometidos por uma grande variedade de agentes bacterianos, micóticos, parasitários e virais, dentre eles encontram-se várias zoonoses emergentes de grande importância para a saúde pública, assim como para outras espécies animais.

\subsubsection{Enfermidades bacterianas}

As enfermidades causadas por bactérias, acompanhadas ou não de doenças parasitárias ou danos traumáticos dos tecidos que permitam a entrada de microrganismos comuns ao meio ambiente do animal são, provavelmente, a maior causa de enfermidade e morte dos mamíferos marinhos (DUNN, 1990; HOWARD et al., 1983a). Como exemplos de bactérias patogênicas que já foram isoladas em mamíferos marinhos pode-se citar: Pasteurella multocida, Staphylococcus aureus, Aeromonas hydrophila, Clostridium perfringens, Streptococcus sp., Erysipelothrix rhusiopatiae, 
Mycobacterium sp., Vibrio sp., Leptospira pomona e Pseudomonas sp., Nocardia (DUNN, 1990; DUNN et al., 2001).

A pneumonia de origem bacteriana é uma das enfermidades mais comuns encontradas nos mamíferos aquáticos e está freqüentemente associada com o encalhe e a morte de cetáceos e pinípedes (HIGGINS, 2000; HOWARD et al., 1983a). Howard e colaboradores (1983a) relatam que as bactérias envolvidas nas pneumonias bacterianas são semelhantes em pinípedes e cetáceos, e estas incluem os gêneros Staphylococcus, Streptococcus, Pseudomonas e Salmonella. Estes autores discutem ainda que, nos pinípedes, estas pneumonias ocorrem mais comumente de forma secundária à infestação parasitária pulmonar, caquexia, trauma ou neoplasias.

Higgins (2000) apresenta uma revisão das bactérias e fungos já isolados em mamíferos marinhos, enfatizando agentes bacterianos identificados recentemente, incluindo o Actinobacillus delphinicola, A. scotiae e Brucella spp.

Uma alta incidência de natimortos já foi reportada em golfinhos-nariz-de-garrafa (Tursiops truncatus) primíparas, sugerindo a possibilidade de infecção por Brucella (MILLER et al., 1999). Nestes casos, os resultados microbiológicos, biomoleculares, e eletroforéticos suportaram a designação de um grupo genômico adicional de Brucella. Estes autores sugeriram o nome de Brucella delphini para os isolamentos obtidos de T. truncatus. Seus achados e os de outros autores (TRYLAND et al., 1999) sustentaram a hipótese de que a brucelose em golfinhos é de ocorrência natural. A significância da doença nestes animais e suas possivveis implicações para a saúde pública são desconhecidas.

A tuberculose causada pelo complexo Mycobacterium tuberculosis é uma enfermidade em ascensão nas colônias naturais e em cativeiro de pinípedes do Hemisfério Sul (BASTIDA et al., 1999; BERNARDELLI et al., 1996; COUSINS et al., 1993; FORSHAW; PHELPS, 1991; WOODS et al., 1995). De acordo com Forshaw e Phelps (1991), apesar da presença de granulomas multifocais com necrose 
caseosa central, a mineralização e a formação de células gigantes não foram achados proeminentes da doença em pinípedes.

A maioria dos indivíduos desenvolveu lesões pulmonares, portanto a inalação foi provavelmente a principal via de infecção (BASTIDA et al., 1999; BERNARDELLI et al., 1996; COUSINS et al., 1993; FORSHAW; PHELPS, 1991; WOODS et al., 1995). Em alguns casos, também foi observada a infecção do trato digestivo (BERNARDELLI et al., 1996; FORSHAW; PHELPS, 1991). Bastida et al., (1999), especulam que a ocorrência da infecção nas colônias naturais de pinípedes deva ser alta, devido aos hábitos gregários de algumas espécies. E não excluem a possibilidade de infecção cruzada com outras espécies de predadores marinhos e terrestres que se alimentem de pinípedes ou de suas carcaças.

Higgins (2000) menciona que a presença do Mycobacterium spp. em mamíferos marinhos não é bem documentada, e aparentemente está limitada aos pinípedes.

A leptospirose, resultante da infecção pela espiroqueta Leptospira interrogans, é uma doença séria que ocorre em humanos e em uma grande diversidade de animais domésticos e selvagens, com grande distribuição geográfica. Ela afeta o fígado, rim e o sistema reprodutivo de animais terrestres e aquáticos (DUNN et al., 2001). A infecção foi reconhecida em leões-marinhos-da-Califórnia (Zalophus californianus) em um surto que ocorreu na década de 70 , afetando animais nas costas do Oregon e da Califórnia (VEDROS et al., 1971). O agente etiológico envolvido foi a Leptospira interrogans, sorovar pomona, que foi isolada no rim e na urina destes animais. Entre os anos de 1981 a 1994 ocorreram surtos regulares nesta população, com intervalos de três a quatro anos, afetando principalmente machos jovens (GULLAND et al., 1996). Dierauf e colaboradores (1985) sugerem a contaminação de água doce por animais domésticos e roedores selvagens como possível fonte de disseminação dos patógenos entre os leões-marinhos. 
Os sintomas clínicos incluíram depressão, polidipsia, desidratação, relutância em utilizar os membros posteriores, febre, anorexia, perda de peso e em casos extremos tremores musculares, vômitos e dor abdominal. Estes estiveram associados à doença renal e problemas reprodutivos nas fêmeas, incluindo abortos e partos prematuros. Os achados de necropsia, vinculados ao rim, incluíram órgãos de consistência endurecida e marcadamente aumentados de tamanho, com perda da diferenciação entre córtex e medula, apresentando ocasionalmente hemorragias subcapsulares e na junção córtico-medular. Somando-se a vesículas biliares apresentando conteúdo espesso e enegrecido; fluido pericárdico amarelado e viscoso. Os achados histopatológicos incluíram nefrite intersticial difusa, glomerulonefrite e nefrite tubular (DIERAUF, et al., 1985; DUNN et al., 2001; GULLAND et al., 1996; GULLAND, 1999).

A leptospirose foi determinada somente em pinípedes. Diagnósticos definitivos ainda não foram realizados em cetáceos (DUNN et al., 2001).

\subsubsection{Enfermidades micóticas}

Apesar de que relatos sobre infecções causadas por fungos sejam relativamente raros, quando comparados aos existentes sobre doenças infecciosas causadas por vírus, bactérias e helmintos, é importante lembrar que os organismos fúngicos podem contribuir de maneira significativa para a mortalidade dos mamíferos marinhos (MIGAKI; JONES, 1983; REIDARSON et al., 2001).

Os fungos patogênicos mais comuns pertencem a um taxon artificial chamado Fungi Imperfecti, que inclui: Aspergillus fumigatus, Blastomyces dermatitidis, Candida spp., Cryptococcus neoformans, Coccidioides immitis e Histoplasma capsulatum. Ainda, a Classe dos Zigomicetos inclui Apophysomyces elegans, Rhizomucor pusillus, Saksenaea vasiformis, entre outros. Lacazia loboi é um fungo não classificado entre os anteriores, porém aparentemente está relacionado com Aspergillus 
fumigatus, Blastomyces dermatitidis, Candida spp., Cryptococcus neoformans, Fusarium spp. (REIDARSON et al., 2001).

Somente alguns fungos endêmicos são capazes de promover a infecção em indivíduos sadios, e estes incluem B. dermatitidis, C. immitis e H. capsulatum (REIDARSON et al., 2001; SWEENEY et al., 1976).

Os Zigomicetos são patógenos oportunistas e necessitam de fatores predisponentes para a ocorrência das infecções. Migaki (1980) sugere como fatores predisponentes condições que estejam associadas à supressão do sistema imune, como deficiências nutricionais, antibioticoterapias de amplo espectro prolongadas, anemias pré-existentes, neoplasias e situações estressantes de etiologia variada causadas por agentes tóxicos, físicos ou infecciosos.

Higgins (2000) e Reidarson et al., (2001) apresentam revisões completas sobre as micoses ocorrentes em mamíferos marinhos.

Cita-se a lobomicose, uma dermatite crônica granulomatosa causada pelo fungo Lacazia loboi, doença que por muitos anos foi reconhecida apenas nos seres-humanos, mas que no início da década de 70 foi diagnosticada nos cetáceos (MIGAKI et al., 1971a), e em 1993 foi observada pela primeira vez em um golfinho-nariz-de-garrafa (Tursiops truncatus) encontrado na costa de Santa Catarina (SIMÕES-LOPES et al., 1993). De acordo com Migaki e Jones (1983), as lesões macro e microscópicas são idênticas às que ocorrem em humanos, sendo restritas à pele. 0 aspecto macroscópico demonstra múltiplas lesões cutâneas esbranquiçadas, elevadas, crostosas e de crescimento nodular. Devido à multifocalidade das lesões estes autores acreditam na auto-inoculação traumática.

Histologicamente, as lesões encontraram-se apenas na derme, causando acantose marcante caracterizada pela proliferação de células epiteliais escamosas e crescimento irregular das papilas dérmicas. Os granulomas eram compostos quase inteiramente por histiócitos, muitos dos quais 
coalesceram, formando células gigantes. As estruturas fúngicas foram encontradas livres ou fagocitadas por histiócitos e células gigantes. A localização anatômica das lesões variou entre os animais estudados, porém concentraram-se principalmente na cabeça, nadadeiras peitorais e caudal, abdômen e pedúnculo caudal (MIGAKI; JONES, 1983).

\subsubsection{Enfermidades virais}

O estudo dos vírus relacionados aos mamíferos marinhos é um campo extremamente vasto e pouco explorado. Dentre as viroses reconhecidas pode-se citar os poxvírus, adenovírus, herpesvírus, influenza vírus, calicivírus, papilomavírus entre outros (BRITT; HOWARD, 1983b; KENNEDYSTOSKOPF, 2001; SMITH; SKILLING, 1979; STOSKOPF, 1990).

Uma descoberta recente tem modificado as hipóteses que procuram explicar os encalhes em massa de diversas espécies de mamíferos marinhos. Esta nova hipótese relaciona os grandes surtos induzidos por morbilivírus em cetáceos, à ocorrência deste tipo de encalhes (DAOUST et al., 1993; DOMINGO et al., 1992; DUIGNAN et al., 1992, 1995 e 1997; DUIGNAN, 1999; LIPSCOMB et al., 1994). A patogênese da infecção do vírus da cinomose focina é similar à do vírus da cinomose canina (DUIGNAN, 1999).

A pneumonia é o achado mais comum, sendo que os pulmões afetados apresentam áreas demarcadas de consolidação em todos os lobos, edema e enfisema. As infecções bacterianas ou micóticas secundárias resultam em broncopneumonias supurativas até hemorrágicas. Grandes cargas parasitárias são comuns. Os odontocetos afetados apresentam muitos ectoparasitas e comensais aderidos à pele, além de grande perda de peso (AZNAR et al., 1994; DOMINGO et al., 1992; DUIGNAN et al., 1992). Estomatites e gengivites ulcerativas agudas ou crônicas podem estar presentes. A leucoencefalomalácia pode ser evidente no cérebro, e a encefalite micótica secundária pode causar necrose e hemorragia (DOMINGO et al., 1992). 
Diversas espécies de pinípedes e de odontocetos estão extraordinariamente predispostos à infecção pelos morbilivírus, devido ao seu comportamento gregário e sociável (DUIGNAN et al., 1992).

A imunoistoquímica foi o método diagnóstico utilizado para demonstrar a presença de antígenos dos morbilivírus em fragmentos de tecidos fixados em solução de formalina 10\% e incluídos em parafina (DAOUST et al., 1993; DOMINGO et al., 1992; KENNEDY et al., 1991).

Os papilomavírus são vírus DNA de fita dupla, não envelopados, altamente espécie específicos. Estes organismos produzem tumores epiteliais benignos na pele e junções mucocutâneas de uma grande variedade de vertebrados, incluindo cetáceos e humanos. As lesões associadas aos papilomavírus (verrugas, papilomas, fibropapilomas e condilomas) podem regressar espontaneamente, porém as induzidas por genotipos específicos destes vírus podem persistir e progredir a carcinomas invasivos em coelhos, bovinos e primatas (VAN BRESSEM, et al., 1999).

Os papilomavírus foram descritos em diversas espécies de cetáceos e os fatores macro e microscópicos foram revisados por Van Bressem et al., (1996).

A papilomatose genital foi reportada em cachalotes (Physeter macrocephalus) por Lambertsen et al., (1987). Estes autores analisaram 31 machos capturados acidentalmente durante atividades pesqueiras no Atlântico Norte, sendo que os papilomas genitais foram encontrados em 10\% (3/31) dos casos. Estas lesões apresentaram-se como formações nodulares múltiplas que variaram de 1 a $6 \mathrm{~cm}$ afetando as faces ventral, lateral e dorsal da superfície peniana. Foram analisados fragmentos de tecido epitelial com e sem lesões para efeitos de comparação. 0 tecido lesado apresentou-se muitas vezes despigmentado e repleto de cicatrizes. As papilas dérmicas eram alongadas e fundiam-se em algumas ocasiões, apresentando infiltrado linfoplasmocitário nos cortes analisados pelos autores. Estes observaram ainda, acantose, figuras de sofrimento nuclear, vacuolização citosplamática e corpúsculos de inclusão. Foram realizadas provas imunoistoquímicas na tentativa de diagnóstico, porém os 
papilomavírus não foram detectados. A confirmação foi feita através da observação de partículas virais intranucleares na microscopia eletrônica.

\subsubsection{Enfermidades parasitárias}

As infecções parasitárias são achados comuns em mamíferos marinhos selvagens. Estes animais apresentam-se mais freqüentemente parasitados do que os indivíduos terrestres, devido ao fato de que a grande maioria dos parasitas que os infecta possui um ciclo de vida indireto, utilizando os peixes como hospedeiros intermediários. Portanto, a contaminação do hospedeiro definitivo ocorre mais comumente através da dieta e, dificilmente através da ingestão acidental ou da contaminação ambiental, como ocorre com as espécies terrestres (HOWARD et al., 1983b). Dierauf (1990b) apresenta listas contendo os endo e ectoparasitas mais comuns encontrados nos mamíferos marinhos.

As parasitoses estão envolvidas entre as possíveis causas de encalhe dos cetáceos, devido à presença de trematóides adultos e de seus ovos no cérebro e cavidades timpânicas (DAILEY; WALKER, 1978; DEGOLLADA, et al., 2002; MORIMITSU et al., 1987; O'SHEA et al., 1991). Migaki et al., (1971b) descrevem e ilustram a severidade das lesões mais comuns produzidas por helmintos em cetáceos e pinípedes. Estas incluem a pneumonia verminótica e granulomas pulmonares, as úlceras e fibroses gástricas e a enterocolite ulcerativa. Dailey e Stroud, (1978) apresentam 14 gêneros de parasitas, juntamente com a patogênese e a patologia associada com a presença de alguns destes parasitas nos cetáceos. Stroud e Dailey, (1978), reportam parasitas e a patologia associada em pinípedes.

Olson et al., (1997) e Measures e Olson, (1999) demonstraram a presença de cistos de Giardia sp. na água do mar e nas fezes de focídeos de diferentes regiões do Canadá. Este agente também foi reconhecido recentemente em leões-marinhos-da-califórnia (Zalophus californianus) (DENG, et al. 
2000). Estes pinípedes são reservatórios potenciais de Giardia nestas regiões, porém seus efeitos sobre os animais e seu potencial zoonótico são desconhecidos (DAILEY, 2001).

O Toxoplasma gondii é de distribuição cosmopolita e afeta uma grande variedade de mamíferos de cativeiro e de vida livre, havendo sido reportado tanto em cetáceos quanto em pinípedes (DAILEY, 2001; GARELL, 1999; HOLSHUH et al., 1985; INSKEEP et al., 1990). Felídeos selvagens e domésticos são os hospedeiros definitivos, liberando oocistos através das fezes. 0 agente pode ser transmitido através da ingestão de água e alimento contaminados com oocistos, ingestão de carne infectada, ou de forma congênita, através da infecção transplacentária com taquizoítos quando a infecção é adquirida durante a prenhez. A parasitemia durante a prenhez causou a infecção do feto (JARDINE; DUBEY, 2002; RESENDES et al., 2002). A severidade das lesões, tanto na mãe quanto no filhote, esteve ligada principalmente à encefalite não-supurativa multifocal. 0 diagnóstico foi revelado através da histopatologia e provas imunoistoquímicas (JARDINE; DUBEY, 2002; RESENDES et al., 2002).

\subsubsection{Doenças metabólicas, tóxicas e neoplásicas}

A contaminação ambiental gerada por derrames de petróleo, poluentes industriais, incluindo compostos organoclorados, hidrocarbonetos policíclicos aromáticos e metais pesados, e ainda esgotos sem saneamento, são fatores de preocupação e interesse mundial. Neste contexto, as espécies marinhas são suscetíveis a longo prazo, devido à exposição crônica à poluentes ambientais (DE GUISE et al., 1994; DE LONG et al., 1973; GILMARTIN, et al., 1976; HARVELL et al., 1999; MARTINEAU et al., 1985, 1988 e 1994). Martineau et al., (1994), descrevem as lesões neoplásicas encontradas em animais encalhados de uma população específica de belugas (Delphinapterus leucas) no Estuário de St. Lawrence, no Canadá, expostas há mais de 50 anos a uma mistura complexa de poluentes industriais, composta principalmente por benzopirenos. 0 benzopireno é um dos 
carcinógenos mais potentes conhecidos para o homem e estes autores consideraram a hipótese destes produtos serem os responsáveis por algumas das neoplasias encontradas nesta população. As neoplasias malígnas envolvidas incluíram adenocarcinoma gástrico, mamário, intestinal; carcinoma hepatocelular e de células transicionais, entre outros. A parcela afetada da população foram animais adultos, tanto machos quanto fêmeas, acima de 16 anos de idade.

Cetáceos e pinípedes são, em sua maioria, predadores que estão no topo da cadeia alimentar, sendo os peixes sua principal fonte de alimento. Como conseqüência, são vítimas de qualquer processo de bioacumulação. Possuem grandes depósitos de gordura com função de isolamento térmico e reserva energética. Contaminantes lipofilicos podem acumular-se no tecido adiposo dos mamíferos e de suas presas. Quando há mobilização das reservas energéticas, os compostos acumulados podem ser liberados em altas concentrações. Estes fatores fazem com que os mamíferos marinhos sejam particularmente vulneráveis aos efeitos de certos tipos de contaminantes. Compostos como os organoclorados, particularmente os bifenóispoliclorados (PCBs), a família dos DDTs e muitos outros listados pela "United Nations Environment Programme" (UNEP), (1991), são lipofílicos e contaminantes ambientais persistentes de importância reconhecida. Alguns produtos da lise e da combustão destes compostos também são tóxicos. Eles induzem à atividade microssomal enzimática hepática, alterando a esteroidogênese ou o catabolismo dos hormônios esteróides, com efeitos no sistema reprodutivo e no sistema imune (UNEP, 1991). Altos níveis destes compostos (>100 mg/kg) foram reportados no tecido adiposo de uma grande variedade de cetáceos e pinípedes (MARTINEAU, et al., 1994; UNEP, 1991). 


\subsubsection{Outras causas de mortalidade}

A interação com a pesca representa a maior ameaça para as populações de cetáceos ao redor do mundo. Este fato faz com que um grande número de animais morra enrredado ou devido a lesões provocadas pelos próprios pescadores, ocasionadas devido a essa interação. Como exemplo, cita-se tiros por armas de fogo, traumas diversos por facadas e golpes intencionais (PERRIN et al., 1994).

O enrredamento pode ainda resultar em lesões crônicas ao invés de morte imediata. Restos de artefatos de pesca ou cordas podem envolver partes do corpo do animal, estrangulando-as conforme 0 animal cresce ou o tempo passa. Pinípedes tendem a reter restos de redes ao redor do pescoço, enquanto que nos cetáceos a tendência é que os artefatos movam-se em direção caudal, envolvendo as nadadeiras ou o pedúnculo (CROXALL et al., 1990; GULLAND et al., 2001).

Além das lesões antropogênicas, tais como o enrredamento, colisões com embarcações, tiros com armas de fogo entre outras, Gulland et al., (2001) citam ainda agressões intra-específicas, defeitos congênitos e afecções reprodutivas com representação menos significativa na mortalidade de animais marinhos. 


\section{MATERIAL E MÉTODO}

\subsection{Animais}

Foram utilizados indivíduos da ordem Cetacea e subordem Pinnipedia, famílias Otariidae e Phocidae. Amostras foram obtidas através de necropsias realizadas em animais recém-mortos encontrados encalhados em praias ou capturados acidentalmente em redes de pesca na região sul e sudeste do Brasil. Excepcionalmente, foram também utilizados espécimes provenientes de centros de reabilitação, zoológicos, aquários ou oceanários.

\subsection{Protocolo de estudo}

\subsubsection{Informações clínicas e de manejo}

As informações clínicas dos animais provenientes de centros de reabilitação foram obtidas junto à divisão veterinária das respectivas instituiç̧ões.

\subsubsection{Patologia}

\subsubsection{Análise necroscópica}

- Exame necroscópico realizado pela pós-graduanda: No comunicado da ocorrência de animais recém-mortos em praias próximas à cidade São Paulo, a mestranda deslocou-se até o litoral para a realização de necropsias e colheita de amostras. Alguns animais foram encaminhados por distintos pesquisadores para a necropsia no Laboratório de Patologia Comparada de Animais Silvestres (LAPCOM) do Departamento de Patologia (VPT) da Faculdade de Medicina Veterinária e Zootecnia da Universidade de São Paulo (FMVZ/USP). A técnica necroscópica empregada foi aquela preconizada por Geraci e Lounsbury (1993c) e Dierauf (1994). 
- Exame necroscópico realizado por terceiros: As amostras foram colhidas por técnicos e profissionais junto a diversos grupos de trabalho com mamíferos marinhos na região sul [(Laboratório de Mamíferos Marinhos e Centro de Recuperação de Animais Marinhos (CRAM) do Museu Oceanográfico Prof. Eliézer de Carvalho Rios, da Fundação Universidade Federal do Rio Grande (FURG) - R.S.; Grupo de Estudos de Mamíferos Aquáticos do Rio Grande do Sul (GEMARS), da Universidade Federal do Rio Grande do Sul - R.S.)] e sudeste [(Projeto Atlantis, Cananéia - S.P., do Instituto de Biociências, Universidade de São Paulo; Centro de Estudos de Encalhes de Mamíferos Marinhos (CEEMAM), do Museu de Pesca de Santos - S.P.; Aquário Municipal de Santos - SP; Projeto BioPesca, Praia Grande - S.P.; FUNDAMAR, São Sebastião - S.P.; Aquário de Ubatuba - S.P.; Fundação Parque Zoológico de São Paulo - S.P.; Centro de Estudos do Mar (CEM), Pontal do Sul, da Universidade Federal do Paraná - P.R.; Projeto MAQUA, Departamento de Oceanografia, Universidade do Estado do Rio de Janeiro - R. J.)]. Ainda, utilizaram-se amostras colhidas pelo Laboratório de Ciências Marinas, Universidad Nacional de Mar del Plata - Argentina; um indivíduo colhido pela equipe do Centro Golfinho Rotador, Fernando de Noronha - P.E.; e um único espécime colhido por pesquisadores do LAPCOM na llha Rei George - Antártica.

Foi solicitado aos executores que os procedimentos necroscópicos e de colheita seguissem as diretrizes expostas no ANEXO I.

\subsubsection{Análise histopatológica}

Fragmentos, de aproximadamente um $\mathrm{cm}^{3}$ dos órgãos principais, foram fixados em solução de formalina a 10\% para a confeç̧ão de lâminas e posterior interpretação histopatológica. 0 procedimento histopatológico foi realizado no Laboratório de Histologia do Departamento de Patologia da Faculdade de Medicina Veterinária e Zootecnia da Universidade de São Paulo (VPT-FMVZ-USP), seguindo 
protocolo rotineiro de inclusão em parafina, obtenção de cortes de aproximadamente $5 \mu \mathrm{m}$, seguindo de coloração com hematoxilina e eosina.

Técnicas histoquímicas especiais de coloração foram utilizadas quando oportunas, incluindo Ácido Periódico de Schiff (PAS) e Grocott para identificação de fungos; método de Ziehl-Neelsen para bacilos álcool ácido resistentes; colorações de Gram, modificadas por Brown-Hopps e Brown-Brenn, para bactérias em geral; Vermelho Congo para determinação de amiloidose; Tricrômico de Masson para a confirmação de fibroplasia; coloração de Perls para hemossiderose; Giemsa e azul de toluidina para ressaltar as estruturas celulares; Sudan Black para lipídeos e Alcian Blue para visualização de carboidratos (PROPHET et al., 1991).

As causas de morte foram classificadas de acordo com a sistematização proposta por Montali (1991), apresentadas no ANEXO II.

\subsubsection{Estudo microbiológico}

Durante o procedimento necroscópico realizado no LAPCOM colheram-se amostras para 0 cultivo microbiológico de sangue, fluidos e órgãos.

O sangue obtido através da punção cardíaca, foi imediatamente semeado em meio para hemocultura Probac ${ }^{\circledR}$ e incubado em aerobiose e microaerofilia, a $37^{\circ} \mathrm{C}$. 0 mesmo foi plaqueado a cada três dias, ou logo após a verificação de turvação em ágar-sangue, perfazendo-se um total de três plaqueamentos.

Para o cultivo microbiológico de fragmentos de órgãos, estes foram triturados em solução salina estéril e inoculados em caldo $\mathrm{BHI}$ (infusão de cérebro e coração). Foram incubados a $37^{\circ} \mathrm{C}$ em aerobiose e microaerofilia. Após 24 horas, foram plaqueados em ágar-sangue. 
Simultaneamente, as amostras de sangue e triturado de órgãos foram semeados em ágarSabouraud - dextrose com cloranfenicol, para verificar-se o crescimento de fungos. 0 material assim processado foi incubado a 25 e $37^{\circ} \mathrm{C}$, permanecendo em observação por 30 dias.

As bactérias isoladas foram classificadas de acordo com KRIEG; HOLT (1984) e reconhecidas com o auxílio do sistema API de identificação bioquímica (Galerias API ${ }^{\circledR}$ - bioMérieux).

\subsubsection{Estudo parasitológico}

Durante a necroscopia e colheita de fragmentos para histopatologia, cuidados especiais foram tomados com todos os órgãos, em especial com o trato gastrointestinal, com vistas à pesquisa de parasitos metazoários. Os segmentos intestinais, estômago e pulmão foram congelados e posteriormente abertos individualmente dentro de recipiente plástico e seus conteúdos passados por uma peneira. Todo o material colhido foi observado em lupa para a separação dos parasitos, que foram contados e armazenados em frascos com álcool $70 \%$ (nematóides e acantocéfalos) e formol 10\% (trematóides e cestóides). O exame parasitológico e a identificação dos parasitos foram realizados pela pós-graduanda Juliana Marigo, durante o desenvolvimento de seu trabalho de mestrado intitulado: "Patologia Comparada das Principais Enfermidades Parasitárias de Mamíferos Marinhos Encontrados na Costa Sudeste e Sul do Brasil", realizado junto ao LAPCOM (FAPESP No 00/14669-0). Após a confecção de lâminas, a identificação das espécies parasitas foi feita com base em literatura apropriada (DAVEY, 1971; DELYAMURE, 1955; DOUGHERTY, 1944; PRICE, 1932; YAMAGUTI, 1963). 


\section{RESULTADOS}

\subsection{Amostras}

As amostras utilizadas para a realização do trabalho são apresentadas no ANEXO III. De um total de 152 amostras de animais da ordem Cetacea (14 espécies) e 45 da subordem Pinnipedia (seis espécies), recebidas e colhidas pelo LAPCOM, foram selecionados para este trabalho $55,8 \%$ (110/197) dos indivíduos, correspondendo a $51,9 \%$ (79/152) dos cetáceos e 68,8\% (31/45) dos pinípedes recebidos. A Tabela 1 apresenta os 110 casos selecionados e a correlação das várias identificações empregadas em função da origem e cadastramento do material junto aos Laboratórios de Patologia Comparada de Animais Silvestres e de Histologia, indexados pelo "Caso No.".

A seleção do material baseou-se na qualidade e quantidade de amostras disponíveis em cada caso. O restante das amostras disponibilizadas para o projeto, mas não utilizadas para este trabalho específico, complementa o banco de tecidos de animais silvestres mantido pelo Registro de Patologia Comparada de Animais Selvagens (RPC).

Tabela 1. Correlação das várias identificações empregadas ao material disponível em função da espécie, origem e cadastramento junto aos Laboratórios de Patologia Comparada de Animais Silvestres e de Histologia, indexados pelo "Caso No.". Sudeste e sul do Brasil, 1997 $-2002$

\begin{tabular}{|c|c|c|c|c|}
\hline $\begin{array}{c}\text { Caso } \\
\text { No. }\end{array}$ & Espécie & No. de origem & $\begin{array}{c}\text { No. } \\
\text { RPC }\end{array}$ & No. Histologia \\
\hline 1 & Eumetopias jubatus & ZOOSAO & $98 / 301$ & 35.532 e $382 \mathrm{H}-1$ \\
\hline 2 & Sotalia fluviatilis & DELPHINUS 01 & $98 / 302$ & 35.533 \\
\hline 3 & Sotalia fluviatilis & IPeC 093 & $99 / 416$ & 37.462 \\
\hline 4 & Pontoporia blainvillei & IPeC 118 & $99 / 417$ & 37.464 \\
\hline 5 & Pontoporia blainvillei & IPeC 119 & $99 / 418$ & 37.465 \\
\hline 6 & Lobodon carcinophagus & CRAM & $99 / 419$ & 37.466 \\
\hline 7 & Tursiops truncatus & GEMARS 0820 & $02 / 054$ & $382 \mathrm{H}-9$ \\
\hline 8 & Sotalia fluviatilis & PA 131 & $99 / 499$ & 37.680 \\
\hline
\end{tabular}

Obs.: As alterações na numeração seqüencial observadas na coluna "No. Histologia" refletem adequações internas do Laboratório de Histologia do VPT-FMVZ-USP. 


\begin{tabular}{|c|c|c|c|c|}
\hline $\begin{array}{c}\text { Caso } \\
\text { No. }\end{array}$ & Espécie & No. de origem & $\begin{array}{l}\text { No. } \\
\text { RPC }\end{array}$ & No. Histologia \\
\hline 9 & Pontoporia blainvillei & MO CA 154 & $99 / 500$ & 37.681 \\
\hline 10 & Pontoporia blainvillei & MO CA 177 & $99 / 501$ & 37.682 \\
\hline 11 & Pontoporia blainvillei & MO CA 155 & $99 / 502$ & 37.683 \\
\hline 12 & Pontoporia blainvillei & MO CA 156 & $99 / 503$ & 37.684 \\
\hline 13 & Arctocephalus australis & PAP 004 & $99 / 591$ & 37.893 \\
\hline 14 & Arctocephalus australis & CRAM 346 & $99 / 592$ & 37.894 \\
\hline 15 & Pontoporia blainvillei & MO CA 153 & $99 / 593$ & 37.896 \\
\hline 16 & Arctocephalus australis & UNMP 08-97 & $99 / 594$ & 37.897 \\
\hline 17 & Pontoporia blainvillei & MO CA 176 & $99 / 595$ & 37.898 \\
\hline 18 & Arctocephalus tropicalis & ZOOSAO & $99 / 596$ & 37.899 \\
\hline 19 & Pontoporia blainvillei & $\mathrm{IPeC} 095$ & $00 / 003$ & 38.098 \\
\hline 20 & Pontoporia blainvillei & $\mathrm{IPeC} 097$ & $00 / 004$ & 38.099 \\
\hline 21 & Pontoporia blainvillei & MO CA 193 & $00 / 005$ & 38.100 \\
\hline 22 & Pontoporia blainvillei & MO CA 180 & $00 / 006$ & 38.101 \\
\hline 23 & Pontoporia blainvillei & MO CA 194 & $00 / 007$ & 38.102 \\
\hline 24 & Pontoporia blainvillei & MO CA 195 & $00 / 008$ & 38.103 \\
\hline 25 & Pontoporia blainvillei & MO CA 178 & $00 / 009$ & 38.104 \\
\hline 26 & Pontoporia blainvillei & PA 132 & $00 / 010$ & 38.105 \\
\hline 27 & Stenella longirostris & CGR & $00 / 171$ & 38.600 \\
\hline 28 & Arctocephalus australis & CRAM 362 & $01 / 137$ & 17/00 - VR3 \\
\hline 29 & Arctocephalus australis & CRAM 356 & $01 / 138$ & $17 / 00$ - VR4 \\
\hline 30 & Kogia simus & FUNDAMAR 097 & $02 / 059$ & $382 \mathrm{H}-10$ \\
\hline 31 & Arctocephalus australis & CRAM 319 & $01 / 140$ & 17/00 - VR6 \\
\hline 32 & Arctocephalus australis & CRAM 354 & $01 / 141$ & 17/00 - VR7 \\
\hline 33 & Arctocephalus australis & CRAM 411 & $01 / 144$ & $15 \mathrm{H} / \mathrm{VR} 10$ \\
\hline 34 & Pontoporia blainvillei & CB 12 & $01 / 145$ & $15 \mathrm{H} / \mathrm{VR} 12$ \\
\hline 35 & Kogia breviceps & CEEMAM 90 & $01 / 146$ & 15H/VR13 \\
\hline 36 & Kogia breviceps & UNMP & $01 / 147$ & 15H/ VR14 \\
\hline 37 & Kogia breviceps & UNMP & $01 / 148$ & $15 \mathrm{H} / \mathrm{VR} 15$ \\
\hline 38 & Steno bredanensis & CB 25 & $01 / 149$ & \multirow{2}{*}{$\begin{array}{c}\text { 15H/ VR16 e } 166 \mathrm{H}-2 \\
\text { cérebro } 195 \mathrm{H}-1 \text { a H-5 } \\
\text { + baço H-6 }\end{array}$} \\
\hline & & & & \\
\hline 39 & Arctocephalus tropicalis & $A Q$ 04/00 & $01 / 150$ & $55 \mathrm{H}-17$ \\
\hline 40 & Arctocephalus australis & $A Q 02 / 00$ & $01 / 151$ & $55 \mathrm{H}-18$ \\
\hline 41 & Arctocephalus tropicalis & $A Q 03 / 00$ & $01 / 152$ & $55 \mathrm{H}-19$ \\
\hline 42 & Pontoporia blainvillei & CEEMAM 111 & $01 / 153$ & $55 \mathrm{H}-20$ \\
\hline 43 & Sotalia fluviatilis & CB 33 & $01 / 154$ & $55 \mathrm{H}-21$ \\
\hline 44 & Otaria flavescens & CRAM 540 & $01 / 155$ & $55 \mathrm{H}-22$ e $382 \mathrm{H}-4$ \\
\hline 45 & Tursiops truncatus & CB 28 & $01 / 018$ & $124 \mathrm{H}-2$ \\
\hline 46 & Stenella frontalis & CB 29 & $01 / 006$ & $124 \mathrm{H}-3$ \\
\hline 47 & Stenella frontalis & CB 30 & $01 / 007$ & $124 \mathrm{H}-4$ \\
\hline 48 & Pontoporia blainvillei & CB 26 & $01 / 020$ & $124 \mathrm{H}-6$ \\
\hline
\end{tabular}

Obs.: As alterações na numeração seqüencial observadas na coluna "No. Histologia" refletem adequações internas do Laboratório de Histologia do VPT-FMVZ-USP. 


\begin{tabular}{|c|c|c|c|c|}
\hline $\begin{array}{c}\text { Caso } \\
\text { No. }\end{array}$ & Espécie & No. de origem & $\begin{array}{l}\text { No. } \\
\text { RPC }\end{array}$ & No. Histologia \\
\hline 49 & Pontoporia blainvillei & CB 13 & $01 / 017$ & $124 \mathrm{H}-7$ \\
\hline 50 & Leptonychotes weddellii & RPC 01/029 & $01 / 029$ & $125 \mathrm{H}-5$ e $204 \mathrm{H}-3$ \\
\hline 51 & Sotalia fluviatilis & $\mathrm{IPeC} 054$ & $01 / 051$ & $148 \mathrm{H}-5$ \\
\hline 52 & Pontoporia blainvillei & $\mathrm{IPeC} 055$ & $01 / 052$ & $148 \mathrm{H}-6$ \\
\hline 53 & Pontoporia blainvillei & $\mathrm{IPeC} 056$ & $01 / 053$ & $148 \mathrm{H}-7$ \\
\hline 54 & Pontoporia blainvillei & $\mathrm{IPeC} 065$ & $01 / 054$ & $148 \mathrm{H}-8$ \\
\hline 55 & Arctocephalus tropicalis & FUNDAMAR 13/7/00 & $01 / 072$ & $150 \mathrm{H}-1$ \\
\hline 56 & Pontoporia blainvillei & MO CA 199 & $01 / 073$ & $150 \mathrm{H}-2$ \\
\hline 57 & Pontoporia blainvillei & MO CA 200 & $01 / 074$ & $150 \mathrm{H}-3$ \\
\hline 58 & Pontoporia blainvillei & MO CA 201 & $01 / 075$ & $150 \mathrm{H}-4$ \\
\hline 59 & Pontoporia blainvillei & MO CA 202 & $01 / 076$ & $150 \mathrm{H}-5$ \\
\hline 60 & Pontoporia blainvillei & MO CA 203 & $01 / 077$ & $150 \mathrm{H}-6$ \\
\hline 61 & Pontoporia blainvillei & MO CA 204 & $01 / 078$ & $150 \mathrm{H}-7$ \\
\hline 62 & Pontoporia blainvillei & MO CA 205 & $01 / 080$ & $150 \mathrm{H}-9$ \\
\hline 63 & Pontoporia blainvillei & MO CA 206 & $01 / 081$ & $150 \mathrm{H}-10$ \\
\hline 64 & Pontoporia blainvillei & MO CA 207 & $01 / 082$ & $150 \mathrm{H}-11$ \\
\hline 65 & Pontoporia blainvillei & MO CA 208 & $01 / 083$ & $150 \mathrm{H}-12$ \\
\hline 66 & Pontoporia blainvillei & MO CA 209 & $01 / 084$ & $150 \mathrm{H}-13$ \\
\hline 67 & Pontoporia blainvillei & MO CA 210 & $01 / 085$ & $150 \mathrm{H}-14$ \\
\hline 68 & Pontoporia blainvillei & MO CA 211 & $01 / 095$ & $153 \mathrm{H}-2$ \\
\hline 69 & Pontoporia blainvillei & MO CA 212 & $01 / 096$ & $153 \mathrm{H}-3$ \\
\hline 70 & Pontoporia blainvillei & MO CA 213 & $01 / 097$ & $153 \mathrm{H}-4$ \\
\hline 71 & Pontoporia blainvillei & MO CA 214 & $01 / 098$ & $153 \mathrm{H}-5$ \\
\hline 72 & Pontoporia blainvillei & MO CA 215 & $01 / 099$ & $153 \mathrm{H}-6$ \\
\hline 73 & Pontoporia blainvillei & MO CA 216 & $01 / 100$ & $153 \mathrm{H}-7$ \\
\hline 74 & Pontoporia blainvillei & MO CA 217 & $01 / 101$ & $153 \mathrm{H}-8$ \\
\hline 75 & Pontoporia blainvillei & MO CA 218 & $01 / 102$ & $153 \mathrm{H}-9$ \\
\hline 76 & Pontoporia blainvillei & MO CA 224 & $01 / 108$ & $153 \mathrm{H}-10$ \\
\hline 77 & Pontoporia blainvillei & MO CA 226 & $01 / 109$ & $153 \mathrm{H}-11$ \\
\hline 78 & Pontoporia blainvillei & MO CA 229 & $01 / 110$ & $153 \mathrm{H}-12$ \\
\hline 79 & Pontoporia blainvillei & MO CA 232 & $01 / 111$ & $153 \mathrm{H}-13$ \\
\hline 80 & Pontoporia blainvillei & MO CA 233 & $01 / 112$ & $153 \mathrm{H}-14$ \\
\hline 81 & Balaenoptera acutorostrata & CRAM 003 & $01 / 113$ & $153 \mathrm{H}-15$ \\
\hline 82 & Arctocephalus australis & CRAM 413 & $01 / 114$ & $154 \mathrm{H}-1$ \\
\hline 83 & Arctocephalus australis & CRAM 559 & $01 / 115$ & $154 \mathrm{H}-2$ \\
\hline 84 & Arctocephalus australis & CRAM 561 & $01 / 116$ & $154 \mathrm{H}-3$ \\
\hline 85 & Pontoporia blainvillei & GEMARS-0750 & $01 / 124$ & $154 \mathrm{H}-4$ \\
\hline 86 & Pontoporia blainvillei & GEMARS-0752 & $01 / 125$ & $154 \mathrm{H}-5$ \\
\hline 87 & Pontoporia blainvillei & GEMARS-0753 & $01 / 126$ & $154 \mathrm{H}-6$ \\
\hline 88 & Stenella clymene & GEMARS-0795 & $01 / 127$ & $154 \mathrm{H}-7$ e $195 \mathrm{H}-7$ \\
\hline 89 & Arctocephalus australis & UNMP 17-97 & $01 / 128$ & $154 \mathrm{H}-8$ \\
\hline 90 & Pontoporia blainvillei & UNMP 5/01/98 & $01 / 129$ & $154 \mathrm{H}-9$ \\
\hline
\end{tabular}

Obs.: As alterações na numeração seqüencial observadas na coluna "No. Histologia" refletem adequações internas do Laboratório de Histologia do VPT-FMVZ-USP. 


\begin{tabular}{|c|c|c|c|c|}
\hline $\begin{array}{c}\text { Caso } \\
\text { No. }\end{array}$ & Espécie & No. de origem & $\begin{array}{c}\text { No. } \\
\text { RPC }\end{array}$ & No. Histologia \\
\hline 91 & Pontoporia blainvillei & UNMP 01-98 & $01 / 130$ & $154 \mathrm{H}-10$ \\
\hline 92 & Pontoporia blainvillei & GEMARS-0531 & $01 / 131$ & $154 \mathrm{H}-11$ \\
\hline 93 & Pontoporia blainvillei & GEMARS-0532 & $01 / 132$ & $154 \mathrm{H}-12$ \\
\hline 94 & Stenella frontalis & GEMARS-0599 & $01 / 133$ & $154 \mathrm{H}-13$ \\
\hline 95 & Pontoporia blainvillei & GEMARS-0635 & $01 / 134$ & $154 \mathrm{H}-14$ \\
\hline 96 & Arctocephalus australis & GEMARS-0656 & $01 / 135$ & $154 \mathrm{H}-15$ \\
\hline 97 & Arctocephalus australis & GEMARS-0657 & $01 / 136$ & $154 \mathrm{H}-16$ \\
\hline 98 & Pontoporia blainvillei & CB 31 & $01 / 157$ & $166 \mathrm{H}-1$ \\
\hline 99 & Arctocephalus tropicalis & ZOO SAO 1 & $01 / 165$ & $166 \mathrm{H}-3$ \\
\hline 100 & Arctocephalus tropicalis & ZOO SAO 2 & $01 / 166$ & $166 \mathrm{H}-4$ \\
\hline 101 & Pontoporia blainvillei & GEMARS-0529 & $01 / 167$ & $166 \mathrm{H}-5$ \\
\hline 102 & Stenella coeruleoalba & GEMARS-0592 & $01 / 168$ & $166 \mathrm{H}-6$ \\
\hline 103 & Arctocephalus australis & GEMARS-0663 & $01 / 169$ & $166 \mathrm{H}-7$ \\
\hline 104 & Arctocephalus australis & GEMARS-0675 & $01 / 170$ & $166 \mathrm{H}-8$ \\
\hline 105 & Pontoporia blainvillei & GEMARS-0747 & $01 / 171$ & $166 \mathrm{H}-9$ \\
\hline 106 & Pontoporia blainvillei & GEMARS-0748 & $01 / 172$ & $166 \mathrm{H}-10$ \\
\hline 107 & Arctocephalus tropicalis & RPC 01/246 & $01 / 246$ & $259 \mathrm{H}-1$ \\
\hline 108 & Otaria flavescens & ZOO SAO 3 & $02 / 011$ & $455 \mathrm{H}-8$ \\
\hline 109 & Otaria flavescens & GEMARS 0812 & $02 / 013$ & $382 \mathrm{H}-7$ \\
\hline 110 & Otaria flavescens & GEMARS 0813 & $02 / 014$ & $382 \mathrm{H}-8$ \\
\hline
\end{tabular}

\section{Legenda da coluna "No. Origem":}

AQ: Aquário Municipal de Santos, SP.

CB: Carolina Bertozzi, Projeto BioPesca, Praia Grande, SP.

CEEMAM: Centro de Estudos de Encalhes de Mamíferos Marinhos, Santos, SP.

CGR: Centro Golfinho Rotador, Fernando de Noronha, PE.

CRAM: Centro de Recuperação de Animais Marinhos, Rio Grande, RS.

DELPHINUS: Projeto Delphinus, Ubatuba, SP.

FUNDAMAR: Fundação Mar, São Sebastião, SP.

GEMARS: Grupo de Estudos de Mamíferos Aquáticos do Rio Grande do Sul, Tramandaí, RS.

IPeC: Instituto de Pesquisas de Cananéia, São Paulo e Paraná.

MO-CA: Museu Oceaonográfico - captura acidental, MORG-FURG, Rio Grande, RS.

PA: Projeto Atlantis, Cananéia, SP.

PAP: Projeto Atlantis - pinípede, Cananéia, SP.

RPC: Registro de Patologia Comparada, FMVZ/USP, SP.

UNMP: Universidad Nacional de Mar del Plata, Argentina.

ZOOSAO: Fundação Parque Zoológico de São Paulo, SP.

Obs.: As alterações na numeração seqüencial observadas na coluna "No. Histologia" refletem adequações internas do Laboratório de Histologia do VPT-FMVZ-USP. 


\subsection{Macroscopia}

A Tabela 2 apresenta as principais alterações necroscópicas encontradas em 33,6\% (37/110) dos animais examinados. Nos demais casos, apesar da existência de fichas de encaminhamento, as mesmas não trouxeram qualquer informação macroscópica relevante. Como pode ser visto, em onze cetáceos provenientes de captura acidental em redes de pesca, estes apresentaram estado nutricional bom e as lesões externas mais freqüentemente observadas foram as marcas de dentes de intraespecíficos (Figura 1) e aquelas provocadas pelo enrredamento (Figuras 2 e 3). Observa-se ainda, que edema e congestão pulmonares também aparecem na maioria dos casos descritos de enrredamento.

Com relação aos pinípedes analisados, todos, exceto os Casos No. 50 e 108, foram animais provenientes de encalhes naturais, encontrados mortos nas praias ou que vieram a óbito em centros de reabilitação. Nestes, a caquexia foi um achado freqüente, assim como as alterações relacionadas com o sistema respiratório, incluindo hidrotórax, piotórax, abscedação, aspiração de corpo-estranho (Figura 4). 0 Caso No. 50 foi o de uma foca-de-weddell (Leptonychotes weddellii) capturada acidentalmente em rede de pesca na Antártica, e o Caso No. 108 foi um filhote de leão-marinho (Otaria flavescens), que sofreu morte perinatal em zoológico.

Outros achados macroscópicos relevantes, além daqueles relacionados com o enrredamento foram os cistos ovarianos encontrados no caso No. 34 (Figura 5), a doença renal policística e formações cutâneas verrucosas no Caso No. 38 (Figuras 6 a 9). Além dessas, verificaram-se também formações cutâneas nodulares penianas (Figuras 10 e 11) e a abscedação pulmonar que revelou-se tratar de granulomas parasitários (Figuras 12 e 13a; b ), encontrados no Caso No. 7. 


\subsection{Histopatologia}

Os diagnósticos histológicos principais obtidos em todos $(100 \%$ - 110) os casos são apresentados nas Tabelas 3 e 4. Foram analisados os fragmentos de órgãos de 79 cetáceos e 31 pinípedes.

\subsubsection{Cetáceos}

As espécies estudadas histologicamente, assim como os respectivos "n" são apresentados na Tabela 5. Por sua vez, a Tabela 3 exibe os resultados relativos ao exame microscópico destes animais.

Tabela 5. Distribuição dos cetáceos analisados histologicamente, dispostos a partir da espécie e número de animais analisados. Sudeste e sul do Brasil, 1997 - 2002

\begin{tabular}{|c|c|}
\hline Espécies & "n" \\
\hline Balaenoptera acutorostrata & 1 \\
\hline Kogia breviceps & 3 \\
\hline Kogia simus & 1 \\
\hline Pontoporia blainvillei & 60 \\
\hline Sotalia fluviatilis & 5 \\
\hline Stenella coeruleoalba & 1 \\
\hline Stenella clymene & 1 \\
\hline Stenella frontalis & 3 \\
\hline Stenella longirostris & 1 \\
\hline Steno bredanensis & 1 \\
\hline Tursiops truncatus & 2 \\
\hline Total & 79 \\
\hline
\end{tabular}

\subsubsection{Pinípedes}

As espécies de pinípedes analisados histologicamente e seus respectivos " $n$ " são representados na Tabela 6 . Por sua vez, a Tabela 4 exibe os resultados relativos ao exame microscópico destes animais. 
Tabela 6. Distribuição dos pinípedes analisados histologicamente, dispostos a partir da espécie e número de animais analisados. Sudeste e sul do Brasil, 1997 - 2002

\begin{tabular}{|c|c|}
\hline Espécies & "n" \\
\hline Arctocephalus australis & 17 \\
\hline Arctocephalus tropicalis & 7 \\
\hline Eumetopias jubatus & 1 \\
\hline Leptonychotes weddellii & 1 \\
\hline Lobodon carcinophagus & 1 \\
\hline Otaria flavescens & 4 \\
\hline Total & $\mathbf{3 1}$ \\
\hline
\end{tabular}

\subsection{Causas de morte}

Foram considerados como "causas de morte" os processos principais decorrentes da análise dos resultados obtidos nos diversos exames realizados em cada caso, incluindo a necroscopia, histopatologia, microbiologia e parasitologia, associando-se, quando possível, com os dados do histórico do animal. Os resultados finais obtidos nesta abordagem estão distribuídos nas Tabelas 3 e 4 e Gráficos 1 e 2.

\subsubsection{Cetáceos}

Dos diagnósticos finais elucidados, 88,6\% (70/79) tiveram a morte relacionada com o sistema respiratório, 3,8\% (3/79) devido à origem metabólica, 2,5\% (2/79) causada por agentes infecciosos, 1,3\% (1/79) com origem traumática antropogênica e em 3,8\% (3/79) dos casos a causa de morte não pôde ser determinada devido à autólise ou à pouca quantidade de órgãos encaminhados para análise (Gráfico 1). 


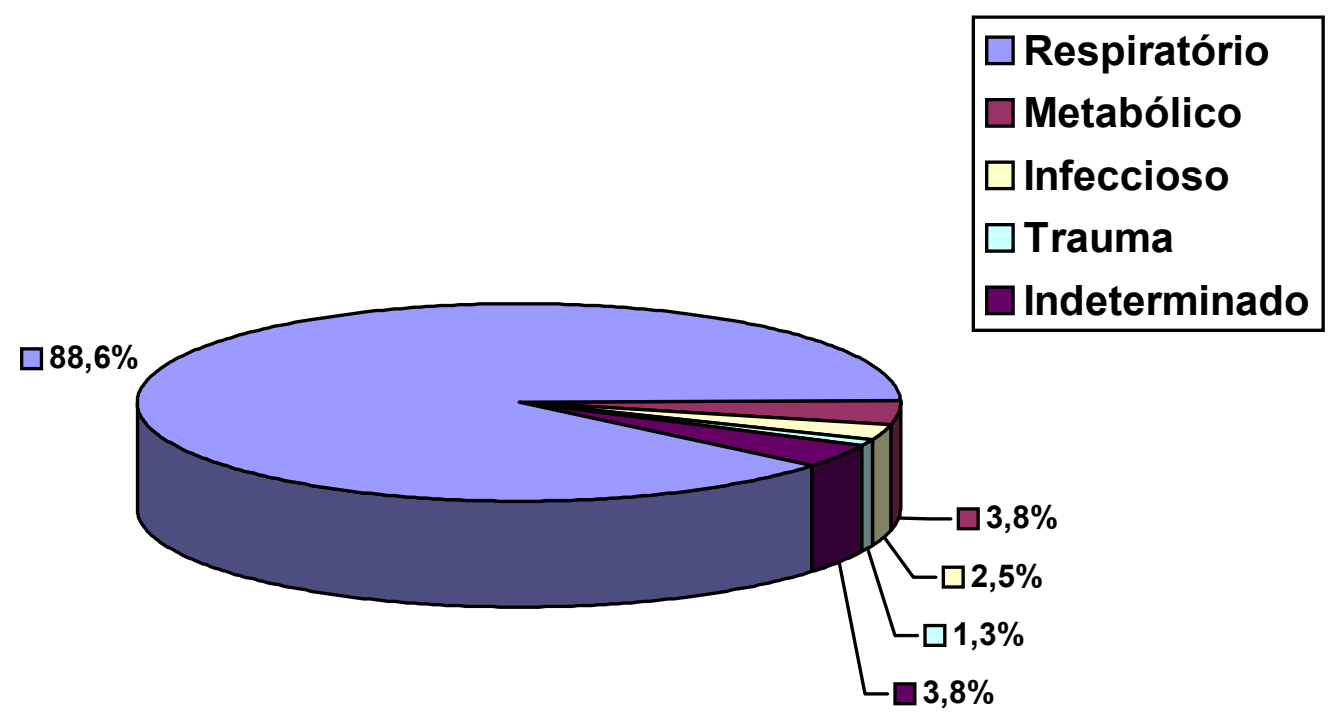

Gráfico 1. Representação dos diagnósticos finais principais que determinaram as causas de morte que afetaram cetáceos, dispostos de acordo com a sistematização proposta por Montali (1991), apresentada no ANEXO II. Sudeste e sul do Brasil, 1997 - 2002.

Dos cetáceos analisados, $76 \%$ (60/79) foram animais que tiveram a morte induzida pela captura acidental em redes de pesca, considerou-se então a causa do óbito destes indivíduos como respiratório, asfixia. Os restantes 24\% (19/79) foram encontrados mortos ou encalharam vivos e vieram a óbito em centros de reabilitação, sendo considerados como encalhes.

Dos 60 animais da espécie Pontoporia blainvillei analisados, 91,7\% (55/60) foram provenientes da captura acidental, e 8,3\% (5/60) provenientes de encalhes.

Os indivíduos que sofreram morte natural relacionada com 0 sistema respiratório representaram 12,6\% (10/79), e estes apresentaram as seguintes afecções: $30 \%(3 / 10)$ pneumonia parasitária; 20\% (2/10) pleuropneumonia; 20\% (2/10) pneumonia intersticial; 20\% (2/10) pneumonia aspirativa; $10 \%(1 / 10)$ broncopneumonia. 


\subsubsection{Pinípedes}

Os animais que vieram a óbito nas praias ou em centros de reabilitação, foram considerados como encalhes. Apenas um indivíduo teve a morte vinculada à pesca, sendo considerado como captura acidental. Dois indivíduos pertenciam a coleções zoológicas (Casos No. 1 e 108).

Nos indivíduos estudados, as afecções primárias afetando o sistema respiratório foram observadas em 48,5\% (15/31) dos casos, constituindo a maioria dos processos. As afecções envolvidas foram 40\% (6/15) pneumonia intersticial; 13,3\% (2/15) pneumonia parasitária; 13,3\% (2/15) pneumonia bacteriana; $13,3 \%(2 / 15)$ asfixia; $6,7 \%$ (1/15) pneumonia lobar; $6,7 \%$ (1/15) broncopneumonia; 6,7\% (1/15) pleuropneumonia.

A morte decorrente de outras causas incluiu: 29,1\% (9/31) de causas metabólicas; 3,2\% (1/31) nutricional; 3,2\% (1/31) digestivo; 3,2\% (1/31) urinário; 3,2\% (1/31) físico; 3,2\% (1/31) síndrome, colapso; 3,2\% (1/31) vandalismo; 3,2\% (1/31) indeterminado (Gráfico 2).

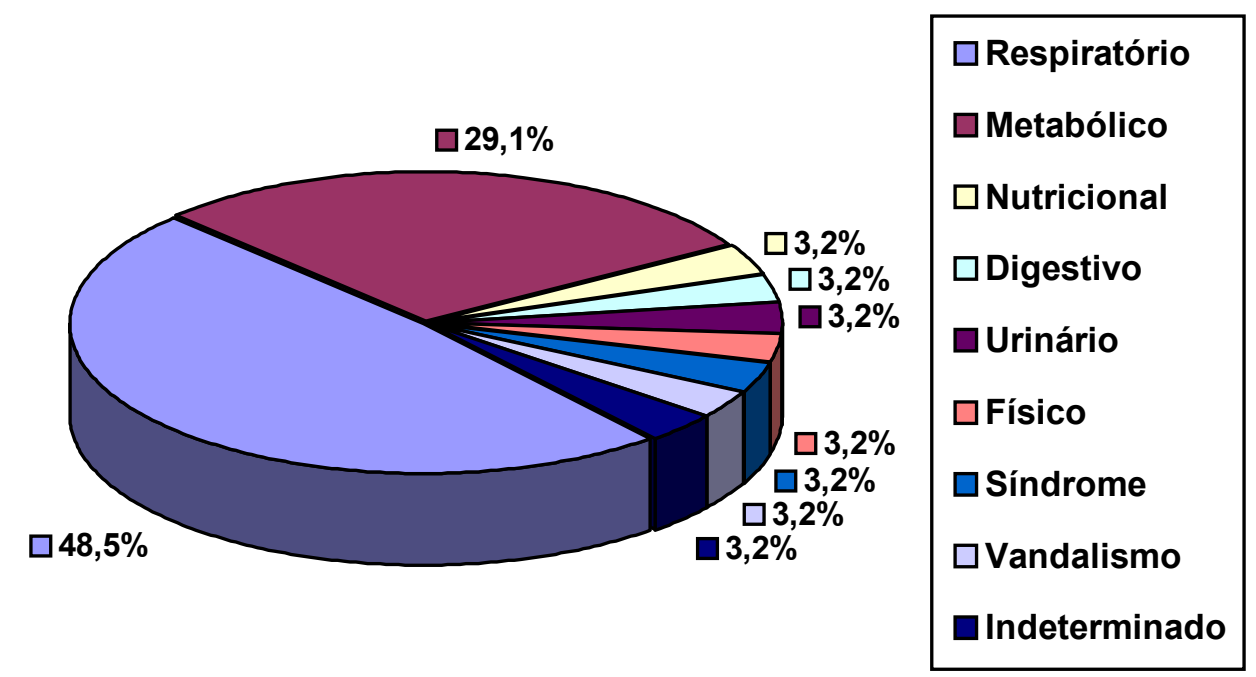

Gráfico 2. Representação dos diagnósticos finais principais que determinaram as causas de morte que afetaram pinípedes, dispostos de acordo com a sistematização proposta por Montali (1991), apresentada no ANEXO II. Sudeste e sul do Brasil, 1997 - 2002. 


\subsection{Microbiologia}

Em 10,9\% (12/110) dos casos, procedeu-se ao exame microbiológico a partir de material colhido durante o procedimento necroscópico. Em 9\% (10/110) dos casos, realizou-se a cultura do sangue periférico colhido assepticamente, tão logo feita a abertura da cavidade torácica. Em 6,3\% (7/110) dos casos, realizou-se o exame microbiológico de fragmentos de órgãos e fluidos corporais. Em $2,7 \%$ (3/110) casos os cultivos microbiológicos foram feitos a partir de swabs.

Os resultados disponíveis são expostos na Tabela 7. Nesta, pode-se observar que o cultivo do sangue periférico foi negativo em $50 \%$ (5/10) das amostras processadas, e não houve o crescimento de fungos e leveduras em nenhuma das amostras.

As bactérias do gênero Staphylococcus foram as mais prevalentes, ocorrendo em 33,3\% (4/12) das amostras analisadas (Casos No. 38, 48 e 98). 0 gênero Pseudomonas cresceu em 16,6\% (2/12) das amostras cultivadas (Caso No. 48).

A bactéria Escherichia coli foi isolada no sangue periférico e pulmão de dois pinípedes (16,6\% - 2/12) distintos (Casos No. 39 e 41) que vieram a óbito em um mesmo centro de reabilitação.

Os gêneros Morganella, Pasteurella, Gemella, Proteus, Klebsiella e Micrococcus foram identificados em casos isolados, e cada um representa 8,3\% das amostras. 


\subsection{Parasitologia}

Do total de 110 casos analisados para este trabalho, 20,2\% (16/79) dos cetáceos e 3,2\% (1/31) dos pinípedes tiveram seus órgãos submetidos à análise parasitológica (Tabela 8).

Tabela 8. Distribuição dos animais submetidos à análise parasitológica, dispostos a partir da espécie e número de animais analisados. Sudeste do Brasil, 1997 - 2002

\begin{tabular}{|c|c|}
\hline Espécies & "n" \\
\hline Arctocephalus tropicalis & 1 \\
\hline Pontoporia blainvillei & 10 \\
\hline Sotalia fluviatilis & 3 \\
\hline Stenella frontalis & 2 \\
\hline Steno bredanensis & 1 \\
\hline Total & $\mathbf{1 7}$ \\
\hline
\end{tabular}

A Tabela 9 apresenta os resultados parasitológicos obtidos. Dentre os intestinos avaliados, 76,4\% (13/17) encontravam-se parasitados. Dos intestinos de Pontoporia blainvillei analisados, 77,7\% (7/10) apresentaram o trematóide Hadwenius pontoporiae com intensidade média de 26,1 parasitos por animal.

Em 100\% (3/3) dos intestinos analisados dos indivíduos da espécie Sotalia fluviatilis foram encontrados os trematóides Hadwenius tursionis, com intensidade média de nove parasitos por animal. Dentre os pulmões avaliados desta mesma espécie 100\% (2/2) encontravam-se parasitados por Halocercus brasiliensis.

Dentre os estômagos 18,1\% (2/11) encontravam-se parasitados. Dos parasitos estomacais já identificados, um exemplar de S. fluviatilis apresentou o acantocéfalo Bolbossoma sp. e o exemplar de Steno bredanensis apresentou aproximadamente 30 trematóides da espécie Braunina cordiformis. 
Tabela 2. Distribuição das principais alterações macroscópicas observadas em cetáceos e pinípedes necropsiados junto ao LAPCOM e por terceiros ( ${ }^{*}$ ), em função do Ca: Sudeste e sul do Brasil, 1997 a 2002

\begin{tabular}{|c|c|c|}
\hline Caso No. & Exame externo & Cavidades corpóreas e sistemas \\
\hline *2 & N.R. & Pleurisia, fibrinosa, difusa, moderada. \\
\hline *7 & Estado nutricional bom & Abscedação pulmonar multifocal. Presença de diversas formações cutâneas nodulares penianas variando de 0,1 a 0,4 cm df \\
\hline *8 & $\begin{array}{l}\text { Dentes fraturados, vários } \\
\text { Marcas de dentes de intra-específicos } \\
\text { Estado nutricional regular }\end{array}$ & $\begin{array}{l}\text { Congestão e edema pulmonares, parasitos nematóides na luz bronquial, parasitos trematóides estomacais, } \\
\text { encurtamento da mandibula. }\end{array}$ \\
\hline *9 & $\begin{array}{c}\text { Marcas de rede } \\
\text { Estado nutricional bom }\end{array}$ & Conteúdo de edema pulmonar em traquéia, congestão e edema pulmonares. \\
\hline${ }^{*} 11$ & $\begin{array}{c}\text { Marcas de rede } \\
\text { Estado nutricional bom }\end{array}$ & Conteúdo de edema pulmonar em traquéia, congestão e edema pulmonares. \\
\hline *12 & $\begin{array}{c}\text { Marcas de rede } \\
\text { Estado nutricional bom } \\
\end{array}$ & Conteúdo de edema pulmonar em traquéia, congestão e edema pulmonares. \\
\hline 13 & $\begin{array}{l}\text { Olho direito consumido por aves (urubus) } \\
\text { Tiros de "chumbinho" em locais de fratura }\end{array}$ & $\begin{array}{l}\text { Hidrotórax, corpo estranho traqueal, conteúdo de edema pulmonar em traquéia, edema, enfisema e congestão pulmonares, } \\
\text { parasitos nematóides estomacais, palidez esplênica, pâncreas friável, fraturas completas do osso nasal e mandíbula direita. }\end{array}$ \\
\hline *14 & $\begin{array}{l}\text { Dilatação abdominal } \\
\text { Estado nutricional bom }\end{array}$ & Congestão pulmonar, aspiração do conteúdo estomacal, congestão hepática, esteatose hepática, dilatação gástrica, gastrite \\
\hline 15 & $\begin{array}{l}\text { Marcas de rede no rostro } \\
\text { Estado nutricional bom }\end{array}$ & Conteúdo de edema pulmonar em traquéia, congestão e edema pulmonares. \\
\hline *18 & $\begin{array}{l}\text { Mucosas pálidas } \\
\text { Caquexia }\end{array}$ & $\begin{array}{l}\text { Áreas de enfisema pulmonar. Linfadenomegalia axilar e mesentérica. Fígado de coloração acastanhada e consistência friáve } \\
\text { Ausência de alimento no estômago. Nematóides aderidos à mucosa estomacal. Íleo, ceco e cólon com conteúdo hemorrágic } \\
\text { Palidez e contração esplênica. Congestão renal. }\end{array}$ \\
\hline 26 & $\begin{array}{l}\text { Marcas no rostro (rede?) } \\
\text { Estado nutricional bom }\end{array}$ & Congestão e edema pulmonares, palidez dos bordos pulmonares, congestão hepática, presença de muco uterino. \\
\hline *27 & NDN & Ascite, peritonite, congestão hepática, gastrite, edema, enfisema e congestão pulmonares, congestão cerebral e cerebelar. \\
\hline *30 & Extensos hematomas na pele & Presença de hematomas e escoriações profundas na região cervical e ventral causados por objeto contuso. Ambos olhos pe \\
\hline *33 & Estado nutricional regular & NDN \\
\hline 34 & $\begin{array}{c}\text { Marcas de rede } \\
\text { Estado nutricional bom }\end{array}$ & Fluido na luz bronquial, congestão e palidez hepáticas, alimento no estômago, cistos ovarianos (E e D). \\
\hline 38 & $\begin{array}{l}\text { Cicatrizes na cabeça } \\
\text { Marcas de dentes de intra-específicos } \\
\text { Formações cutâneas verrucosas } \\
\text { na boca e no ânus }\end{array}$ & $\begin{array}{l}\text { Congestão pulmonar, carneificação e abscedação lobares, pericardite fibrinosa, hidropericárdio. } \\
\text { Parasitos estomacais nematóides, trematóides e acantocéfalos, hepatomegalia, congestão hepática, abscesso esplênico, linł } \\
\text { nefromegalia bilateral de aspecto nodular cístico, nódulos tireoideanos, atrofia córtico-medular adrenal, cavitações encefálica }\end{array}$ \\
\hline
\end{tabular}


Cont. Tabela 2.

\begin{tabular}{|c|c|c|}
\hline Caso No. & Exame externo & Cavidades corpóreas e sistemas \\
\hline *39 & Caquexia & $\begin{array}{l}\text { Tecido subcutâneo gelatinoso, congestão pulmonar, abscedação pulmonar multifocal, hidropericárdio, } \\
\text { mucosa entérica hemorrágica, gastroenterite, palidez hepática com bordos afilados, linfoadenomegalia, palidez esplênica, } \\
\text { petéquias na mucosa vesical, congestão adrenal, congestão cerebral, opacidade corneal esquerda. }\end{array}$ \\
\hline *40 & $\begin{array}{l}\text { Queimaduras nas nadadeiras anteriores } \\
\text { OE perfurado, OD rotação de cristalino }\end{array}$ & $\begin{array}{l}\text { Hidrotórax, ascite, aspecto pulmonar marmorizado, } 1 \text { parasito nematóide estomacal, congestão da mucosa gástrica, } \\
\text { parasitos intestinais acantocéfalos Corynossoma sp., linfoadenomegalia, congestão renal, congestão adrenal, congestão pé }\end{array}$ \\
\hline *41 & Caquexia & $\begin{array}{l}\text { Piotórax, abscedação pulmonar multifocal, parasitos nematóides estomacais, gastrite hemorrágica, úlceração gástrica, } \\
\text { palidez hepática com bordos afilados, mucosa entérica hemorrágica com parasitas acantocéfalos Corynossoma sp., } \\
\text { linfoadenomegalia, palidez esplênica, mucosa vesical congesta. }\end{array}$ \\
\hline *42 & $\begin{array}{l}\text { Cortes nas nadadeiras peitorais e caudal } \\
\text { Estado nutricional bom }\end{array}$ & $\begin{array}{l}\text { Congestão, enfisema e edema pulmonares, abscedação lobar, congestão dos vasos coronários, } \\
\text { mucosa gástrica congesta, mucosa vesical congesta de conteúdo translúcido. }\end{array}$ \\
\hline 43 & $\begin{array}{l}\text { Cortes nas nadadeiras peitorais } \\
\text { Cicatriz circular ao redor do rostro }\end{array}$ & $\begin{array}{l}\text { Ascite, peritonite fibrinosa, pleuropneumonia fibrinosa, parasitos nematóides pulmonares, } \\
\text { abscedação lobar multifocal, baço de consistência friável, fibrina na superfície hepática. }\end{array}$ \\
\hline *44 & Estado nutricional bom & Hidrotórax 30 litros, congestão e edema pulmonares, nematóides estomacais, corpo estranho estomacal (fragmento de rede) \\
\hline *45 & Estado nutricional bom & Congestão pulmonar, abscedação lobar multifocal, pâncreas de consistência endurecida. \\
\hline 46 & $\begin{array}{l}\text { Marcas de rede } \\
\text { Estado nutricional bom }\end{array}$ & Edema e congestão pulmonares, congestão hepática, hepatomegalia, fibrose hepática, linfadenite abscedante. \\
\hline 47 & $\begin{array}{l}\text { Marcas de rede } \\
\text { Crustáceo aderido aos dentes } \\
\text { Estado nutricional bom }\end{array}$ & $\begin{array}{l}\text { Edema e congestão pulmonares, abscedação lobar multifocal, congestão hepática, hepatomegalia, } \\
\text { fibrose hepática, linfadenite purulenta, parasitos nematóides no esôfago. }\end{array}$ \\
\hline *48 & $\begin{array}{l}\text { Escoriações na pele, } \\
\text { ressecamento }\end{array}$ & $\begin{array}{l}\text { Aderência e creptação pulmonares, congestão e edema pulmonares, persistência do ducto arterioso, } \\
\text { palidez apical hepática, enterite, congestão cerebral. }\end{array}$ \\
\hline *49 & $\begin{array}{c}\text { Marcas de rede } \\
\text { Estado nutricional bom }\end{array}$ & $\begin{array}{l}\text { Edema e congestão pulmonar, abscedação lobar multifocal, alimento no esôfago, } \\
\text { conteúdo translúcido na bexiga, congestão cerebral. }\end{array}$ \\
\hline *50 & $\begin{array}{c}\text { Estado nutricional bom } \\
\text { NDN }\end{array}$ & $\begin{array}{l}\text { Sistema vascular venoso: múltiplos sítios, congestão, moderada a severa. Veia Porta: hipertensão portal, severa. Traquéia: c } \\
\text { edema pulmonar. Pulmão: atelectasia, multifocal a coalescente, moderada a severa. Rim: cisto, multifocal, discreto. } \\
\text { Coração: endocárdio, hemorragia, petequial, multifocal, discreta. SNC: congestão e edema, moderado. Evidência de aliment }\end{array}$ \\
\hline *82 & Condição nutricional regular & Presença de parasitas nematóides nos espaços bronquiolares. Estômago sem conteúdo, ausência de parasitos. \\
\hline *83 & Caquexia & $\begin{array}{l}\text { Congestão e edema pulmonares, aspiração do conteúdo estomacal, presença de corpos estranhos estomacais, } \\
\text { esteatose hepática, fígado de consistência friável. }\end{array}$ \\
\hline${ }^{*} 99$ & Estado nutricional bom & Congestão polivisceral. Órgãos de temperatura elevada. \\
\hline *100 & $\begin{array}{l}\text { Estado nutricional bom } \\
\text { OE perfurado e repleto de secr. purulenta }\end{array}$ & Congestão polivisceral. Órgãos de temperatura elevada. \\
\hline
\end{tabular}


Cont. Tabela 2.

\begin{tabular}{|c|c|l|}
\hline Caso No. & Exame externo & \multicolumn{1}{c|}{ Cavidades corpóreas e sistemas } \\
\hline \hline $\mathbf{9 8}$ & $\begin{array}{c}\text { Marcas de rede no rostro e nadadeiras } \\
\text { peitorais, cicatriz na cabeça e abdomen } \\
\text { Marcas de dentes de intra-específicos } \\
\text { na nadadeira caudal. } \\
\text { Opacidade cristalino OE }\end{array}$ & $\begin{array}{l}\text { Pleuropneumonia fibrinosa, edema pulmonar, hidropericárdio, ascite, congestão e linfoadenomegalia, } \\
\text { congestão e aderência hepáticas, lesão por objeto contundente em resolução, congestão renal, congestão da mucosa vesice } \\
\text { hematoma peniano, congestão tireoideana, cistos pancreáticos, congestão cerebral. }\end{array}$ \\
\hline 107 & $\begin{array}{c}\text { OD e genitais consumidos por aves } \\
\text { Dentes fraturados } \\
\text { Caquexia }\end{array}$ & $\begin{array}{l}\text { Parasitos encistados no tecido subcutâneo, corpo estranho traqueal (areia), edema, enfisema e congestão pulmonares, } \\
\text { pulmão de aspecto marmorizado, fibrose valvular cardíaca, palidez dos bordos hepáticos, úlceras estomacais, } \\
\text { enterite hemorrágica, linfoadenomegalia mediastínica, congestão adrenal. }\end{array}$ \\
\hline 108 & NDN & $\begin{array}{l}\text { Ascite, congestão pulmonar, enfisema e áreas atelectásicas, aspiração de conteúdo estomacal, congestão da mucosa gástriı } \\
\text { congestão da mucosa vesical. }\end{array}$ \\
\hline${ }^{* 109}$ & $\begin{array}{c}\text { Pequenas escoriações nas nada- } \\
\text { deiras anteriores e posteriores } \\
\text { Bom estado nutricional }\end{array}$ & $\begin{array}{l}\text { Grande quantidade de fibrina na traquéia e espaços bronquiolares. Congetão e edema pulmonares. } \\
\text { Congestão hepática. }\end{array}$ \\
\hline${ }^{* 110}$ & Caquexia & $\begin{array}{l}\text { Congestão, edema e enfisema pulmonares. Pulmão de aspecto marmorizado. Congestão hepática, hepatomegalia. } \\
\text { Vesícula biliar repleta. }\end{array}$ \\
\hline
\end{tabular}

N.R.: Não reportado

NDN: Nada digno de nota

OD: Olho direito

OE: Olho esquerdo

SNC: Sistema nervoso central 
Tabela 3. Distribuição dos caracteres individuais, exames laboratoriais realizados, diagnósticos morfológicos principais e causas de morte observados em cetáceos em função do Caso No. Sudeste e sul do Brasil, 1997 a 2002.

\begin{tabular}{|c|c|c|c|c|c|}
\hline & ${ }^{*}$ Caracteres & & & & \\
\hline Caso No. & individuais & Exames laboratorias & \begin{tabular}{|c|} 
Diagnósticos morfológicos principais \\
\end{tabular} & Causa de morte & Comentários \\
\hline 2 & $\begin{array}{l}\text { Sotalia fluviatilis } \\
\text { Macho, adulto } \\
\text { Peso: } 90 \mathrm{~kg}\end{array}$ & Histopatológico: Coloração H.E. & $\begin{array}{l}\text { Pulmão: Pleuropneumonia, fibrinosa, moderada. Pneumonia, intersticial, aguda, multifocal, } \\
\text { moderada. } \\
\text { Presença de bactérias de putrefação. }\end{array}$ & Respiratório, pleuropneumonia. & Encalhe. \\
\hline 3 & $\begin{array}{l}\text { Sotalia fluviatilis } \\
\text { Macho, }<1 \text { ano } \\
\text { CT: } 143,5 \mathrm{~cm} \\
\text { Peso: } 43 \mathrm{~kg}\end{array}$ & $\begin{array}{l}\text { Histopatológico: Coloração H.E. } \\
\text { Parasitológico }\end{array}$ & $\begin{array}{l}\text { Pulmão: Broncopneumonia. Pneumonia, lobular, fibrinopurulenta, difusa, moderada a severa. } \\
\text { Congestão e hemorragia moderadas. Áreas de consolidação, enfisema e edema pulmonares. } \\
\text { Infiltrado inflamatório misto difuso no intersticio, predominantemente polimorfonuclear, com } \\
\text { grande quantidade de eosinófilos. } \\
\text { Vasos sanguineos leucocitose, múltiplos sitios. }\end{array}$ & Respiratório, broncopneumonia. & Encalhe. \\
\hline 4 & $\begin{array}{l}\text { Pontoporia blainvillei } \\
\text { Jovem } \\
\text { CT: } 98 \mathrm{~cm}\end{array}$ & $\begin{array}{l}\text { Histopatológico: Coloração H.E. } \\
\text { Parasitológico }\end{array}$ & | & Indeterminado. & Encalhe. \\
\hline 5 & $\begin{array}{l}\text { Pontoporia blainvillei } \\
\text { Macho, jovem } \\
\text { CT: } 113,5 \mathrm{~cm}\end{array}$ & $\begin{array}{l}\text { Histopatológico: Coloração H.E. } \\
\text { Parasitológico }\end{array}$ & \begin{tabular}{|l} 
Pulmão: Congestão severa, hemorragia multifocal. \\
Pneumonia, crônica, granulomatosa por C.E., cristais de colesterol.
\end{tabular} & Respiratório, asfixia. & Captura acidental em rede de pesca. \\
\hline 7 & $\begin{array}{l}\text { Tursiops truncatus } \\
\text { Macho, adulto } \\
\text { CT: } 299 \mathrm{~cm}\end{array}$ & $\begin{array}{l}\text { Histopatológico: Colorações H.E., } \\
\text { Gram, PAS e Ziehl-Neelsen }\end{array}$ & $\begin{array}{l}\text { Pulmâa: Pneumonia, intersticialal, crônica, difusa, moderada. Pneumonia, granulomatosa, } \\
\text { parasitária. Pneumonia, abscedante, moderada. } \\
\text { Figado: Fibrose, moderada. } \\
\text { Baço: Depleção linfóide moderada. Linfocitólise moderada. } \\
\text { Linfonodo: Depleção linfóide moderada. Linfadenite, piogranulomatosa, bacteriana } \\
\text { Gram negativa, multifocal, moderada. } \\
\text { Pênis: Hiperplasia linfóide marcante associada a balanite, crônica, multifocal, coales- } \\
\text { cente, moderada. Predominância de células mononucleares com necrose das } \\
\text { projeçōes dérmicas. }\end{array}$ & Respiratório, pneumonia, parasitária. & Encalhe. \\
\hline 8 & $\begin{array}{l}\text { Sotalia fluviatilis } \\
\text { Macho, adulto } \\
\text { CT: } 196 \mathrm{~cm} \\
\text { Peso: } 92 \mathrm{~kg} \\
\end{array}$ & Histopatológico: Coloração H.E. & $\begin{array}{l}\text { Pulmäo: Presença de Metastrongilidae e larvas, pneumonia, intersticial, } \\
\text { crônica, difusa, moderada a severa. } \\
\text { Estômago: Gastrite, eosinofilica, focal, moderada a severa. } \\
\text { Baço: Depleção folicular. }\end{array}$ & $\begin{array}{l}\text { Respiratório, pneumonia, parasitária, } \\
\text { Metastrongilidae. }\end{array}$ & Encontrado morto boiando. \\
\hline 9 & $\begin{array}{l}\text { Pontoporia blainvillei } \\
\text { Macho, adulto } \\
\text { CT: } 136,5 \mathrm{~cm} \\
\text { Peso: } 28,6 \mathrm{~kg}\end{array}$ & Histopatológico: Coloração H.E. & $\begin{array}{l}\text { Pulmão: Congestão e hemorragia moderadas a severas. Edema moderado. } \\
\text { Figado: Congestão moderada. Presença de polimorfonucleares nos sinusóides. } \\
\text { Rim: Congestão moderada. }\end{array}$ & Respiratório, asfixia. & Captura acidental em rede de pesca. \\
\hline 10 & $\begin{array}{l}\text { Pontoporia blainvillei } \\
\text { Macho, adulto } \\
\text { CT: } 120 \mathrm{~cm} \\
\text { Peso: } 26 \mathrm{~kg}\end{array}$ & Histopatológico: Coloração H.E. & $\begin{array}{l}\text { Pulmão: Congestão, edema e hemorragia difusos, moderados. Presença de corpo } \\
\text { estranho no espaço alveolar. } \\
\text { Figado: Congestão moderada. Hemossiderose moderada. } \\
\text { Baço: Congestão e hemorragia moderadas. Hiperplasia linfóide associada com necro- } \\
\text { se individual de linfócitos, moderada. } \\
\text { Rim: Congestão moderada a severa. }\end{array}$ & Respiratório, asfixia. & Captura acidental em rede de pesca. \\
\hline 11 & $\begin{array}{l}\text { Pontoporia blainvillei } \\
\text { Macho, adulto } \\
\text { CT: } 137,5 \mathrm{~cm} \\
\text { Peso: } 29,6 \mathrm{~kg}\end{array}$ & Histopatológico: Coloração H.E. & Pulmão: Congestão, edema e hemorragia moderados a severos. & Respiratório, asfixia. & Captura acidental em rede de pesca. \\
\hline 12 & $\begin{array}{l}\text { Pontoporia blainvillei } \\
\text { Macho, adulto } \\
\text { CT: } 137 \mathrm{~cm} \\
\text { Peso: } 28,6 \mathrm{~kg}\end{array}$ & Histopatológico: Coloração H.E. & Pulmão: Congestão, edema e hemorragia moderados. & Respiratório, asfixia. & Captura acidental em rede de pesca. \\
\hline 15 & $\begin{array}{l}\text { Pontoporia blainvillei } \\
\text { Fêmea, adulto } \\
\text { Peso: } 26 \mathrm{~kg}\end{array}$ & Histopatológico: Coloração H.E. & $\begin{array}{l}\text { Pulmão: Congestão e hemorragia moderadas. } \\
\text { Figado: Congestão moderada. Destrabeculação moderada. } \\
\text { Linfonodo: Evidenciação dos centros germinativos. }\end{array}$ & Respiratório, asfixia. & Captura acidental em rede de pesca. \\
\hline
\end{tabular}




\begin{tabular}{|c|c|c|c|c|c|}
\hline \multicolumn{2}{|c|}{ Cont. Tabela 3} & \multirow[b]{2}{*}{\begin{tabular}{|l|} 
Exames laboratorias \\
\end{tabular}} & \multirow[b]{2}{*}{ Diagnósticos morfológicos principais } & \multirow[b]{2}{*}{\begin{tabular}{|l|} 
Causa de morte \\
\end{tabular}} & \multirow{2}{*}{ Comentários } \\
\hline Caso No. & $\begin{array}{l}{ }^{*} \text { Caracteres } \\
\text { individuais }\end{array}$ & & & & \\
\hline 17 & $\begin{array}{l}\text { Pontoporia blainvillei } \\
\text { Macho, adulto } \\
\text { CT: } 132,1 \mathrm{~cm} \\
\text { Peso: } 26,7 \mathrm{~kg}\end{array}$ & Histopatológico: Coloraçăo H.E. & $\begin{array}{l}\text { Pulmão: Congestão e hemorragia severas. Pneumonią crônica, focal, granulomatosa } \\
\text { por C.E., cristais de colesterol. } \\
\text { Figado: Congestão moderada. Hepatite, granulocitica, difusa, associada a leucocitose } \\
\text { granulocitica, moderada. } \\
\text { Linfonodo: Hiperplasia linfoide severa. }\end{array}$ & Respiratório, asfixia. & Captura acidental em rede de pesca. \\
\hline 19 & $\begin{array}{l}\text { Pontoporia blainvillei } \\
\text { Macho, jovem } \\
\text { CT: } 113,7 \mathrm{~cm} \\
\text { Peso: } 16 \mathrm{~kg}\end{array}$ & $\begin{array}{l}\text { Histopatológico: Colorações H.E., } \\
\text { Gram e PAS } \\
\text { Parasitológico }\end{array}$ & $\begin{array}{l}\text { Pulmão: Pleuropneumonia, plasmocitária, mista, moderada a severa. } \\
\text { Pneumonia bacteriana Gram Negativa, cujo agente não foi identificado. } \\
\text { Baço: Hiperplasia linfóide moderada. }\end{array}$ & Respiratório, asfixia. & Captura acidental em rede de pesca. \\
\hline 20 & $\begin{array}{l}\text { Pontoporia blainvillei } \\
\text { Fêmea, jovem } \\
\text { CT: } 95 \mathrm{~cm} \\
\text { Peso: } 10,7 \mathrm{~kg} \\
\end{array}$ & $\begin{array}{l}\text { Histopatológico: Coloração H.E. } \\
\text { Parasitológico }\end{array}$ & $\begin{array}{l}\text { Pulmão: Congestão, edema e hemorragia moderados. } \\
\text { Figado: Congestão moderada. } \\
\text { Baço: Hiperplasia linfóide moderada. }\end{array}$ & Respiratório, asfixia. & Captura acidental em rede de pesca. \\
\hline 21 & $\begin{array}{l}\text { Pontoporia blainvillei } \\
\text { Fêmea, jovem } \\
\text { CT: } 116 \mathrm{~cm} \\
\text { Peso: } 20,6 \mathrm{~kg} \\
\end{array}$ & Histopatológico: Coloração H.E. & $\begin{array}{l}\text { Pulmão: Congestão e hemorragia moderadas a severas. Raros polimorfonucleares } \\
\text { pelo intersticio e capilares. } \\
\text { Rim: Congestâo moderada. }\end{array}$ & Respiratório, asfixia. & Captura acidental em rede de pesca. \\
\hline 22 & $\begin{array}{l}\text { Pontoporia blainvillei } \\
\text { Macho, jovem } \\
\text { CT: } 113,5 \mathrm{~cm} \\
\text { Peso: } 19,6 \mathrm{~kg}\end{array}$ & Histopatológico: Coloração H.E. & \begin{tabular}{|l|} 
Pulmão: Congestão e hemorragia moderadas. \\
Figado: Congestão moderada. Leucocitose, difusa, moderada. Degeneração macro e \\
microgoticular moderada.
\end{tabular} & Respiratório, asfixia. & Captura acidental em rede de pesca. \\
\hline 23 & $\begin{array}{l}\text { Pontoporia blainvillei } \\
\text { Fêmea, jovem } \\
\text { CT: } 123,3 \mathrm{~cm} \\
\text { Peso: } 29,5 \mathrm{~kg} \\
\end{array}$ & Histopatológico: Coloração H.E. & $\begin{array}{l}\text { Pulmão: Edema sub-pleural associado a pneumonia lobar moderada por C. E. } \\
\text { Pneumonia crônica granulomatosa moderada induzida por C.E., cristais de colesterol. } \\
\text { Congestão e hemorragia moderadas. } \\
\text { Figado: Congestão moderada. }\end{array}$ & Respiratório, asfixia. & Captura acidental em rede de pesca. \\
\hline 24 & $\begin{array}{l}\text { Pontoporia blainvillei } \\
\text { Macho, adulto } \\
\text { CT: } 143,2 \mathrm{~cm} \\
\text { Peso: } 31,5 \mathrm{~kg}\end{array}$ & Histopatológico: Coloração H.E. & \begin{tabular}{|l|} 
Pulmão: Congestão e hemorragia severas. \\
Rim: Congestão e hemorragia moderadas.
\end{tabular} & Respiratório, asfixia. & Captura acidental em rede de pesca. \\
\hline 25 & $\begin{array}{l}\text { Pontoporia blainvillei } \\
\text { Macho, jovem } \\
\text { CT: } 123,4 \mathrm{~cm} \\
\text { Peso: } 23,3 \mathrm{~kg}\end{array}$ & Histopatológico: Coloração H.E. & $\begin{array}{l}\text { Pulmão: Congestão moderada. Pneumonia, intersticial, aguda, multifocal, moderada. } \\
\text { Figado: Congestão moderada. } \\
\text { Baço: Linfocitólise de células individuais moderada, ausência de centros germinativos. } \\
\text { Histiocitose moderada. } \\
\text { lintestino: Enterite, plasmocitária, difusa, moderada. }\end{array}$ & Respiratótio, asfixia. & Captura acidental em rede de pesca. \\
\hline 26 & $\begin{array}{l}\text { Pontoporia blainvillei } \\
\text { Fêmea, adulta } \\
\text { CT: } 130 \mathrm{~cm} \\
\text { Peso: } 19,2 \mathrm{~kg} \\
\end{array}$ & Histopatológico: Coloração H.E. & $\begin{array}{l}\text { Pulmão: Pleuropneumonia, multifocal, moderada. Pneumonia, crônica, granulomatosa, } \\
\text { severa, induzida por C. E., cristais de colesterol. } \\
\text { Baço: Hiperplasia linfóide moderada. } \\
\text { Linfonodo: Hiperplasia linfóide moderada. }\end{array}$ & Respiratório, pleuropneumonia. & $\begin{array}{l}\text { Encontrado morto e encaminhado a instituição } \\
\text { de pesquisa. }\end{array}$ \\
\hline 27 & $\begin{array}{l}\text { Stenella longirostris } \\
\text { macho, filhote } \\
\text { CT: } 89 \mathrm{~cm}\end{array}$ & $\begin{array}{l}\text { Histopatológico: Coloraçõ̃es H.E., } \\
\text { Gram, PAS e Sudan Black }\end{array}$ & $\begin{array}{l}\text { Pulmão: Congestão moderada. Atelectasia, multifocal. } \\
\text { Figado: Lipidose severa. Comprometimento dos sinusóides periportais. Presença de } \\
\text { figuras de sofrimento nuclear. Congestão moderada. } \\
\text { Rim: Lipidose severa. Peritonite infecciosa bacteriana Gram positiva. } \\
\text { Baço: Depleção linfóide generalizada severa. } \\
\text { Linfonodo: Hipoplasia linfóide moderada. } \\
\text { Timo: Linfocitólise, difusa, moderada a severa. } \\
\end{array}$ & Metabólico, lipidose hepato-renal. & Encontrado morto boiando. \\
\hline 30 & $\begin{array}{l}\text { Kogia simus } \\
\text { Macho, adulto } \\
\text { CT: } 230 \mathrm{~cm}\end{array}$ & Histopatológico: Coloração H.E. & $\begin{array}{l}\text { Pulmão: Congestão severa. Hemorragia, multifical per diapedeses, severa. Calcifica- } \\
\text { ção óssea insipiente dos anéis cartilaginosos. } \\
\text { Estômago: Granuloma parasitário na submucosa. } \\
\text { Figado: Extensas áreas hemorrágicas. Destrabeculação, severa. } \\
\text { Rim: Congestão e hemorragia, multifocais, moderados. } \\
\text { Testiculo: Ativo. }\end{array}$ & Trauma, vandalismo. & Encalhou vivo e foi agredido até a morte. \\
\hline 34 & $\begin{array}{l}\text { Pontoporia blainvillei } \\
\text { Fêmea, adulta } \\
\text { CT: } 130 \mathrm{~cm} \\
\text { Peso: } 21 \mathrm{~kg} \\
\end{array}$ & \begin{tabular}{|l} 
Histopatológico: Coloração H.E. \\
Parasitológico \\
Bacteriológico
\end{tabular} & \begin{tabular}{|l|} 
Pulmão: Congestão moderada. \\
Figado: Congestão moderada. \\
Ovário: Cistos, múttiplos sítios.
\end{tabular} & Respiratório, asfixia. & Captura acidental em rede de pesca. \\
\hline
\end{tabular}




\begin{tabular}{|c|c|c|c|c|c|}
\hline \multicolumn{2}{|c|}{ Cont. Tabela 3} & \multirow{2}{*}{\multicolumn{2}{|c|}{ Diagnósticos morfológicos principais }} & \multirow[b]{2}{*}{ Causa de morte } & \multirow[b]{2}{*}{ Comentários } \\
\hline Caso No. & $\begin{array}{l}{ }^{*} \text { Caracteres } \\
\text { individuais }\end{array}$ & & & & \\
\hline 35 & $\begin{array}{l}\text { Kogia breviceps } \\
\text { Fêmea, adulta } \\
\text { CT: } 288 \mathrm{~cm}\end{array}$ & Histopatológico: Coloração H.E. & $\begin{array}{l}\text { Pulmão: Congestão, edema e hemorragia moderados. } \\
\text { Figado: Congestão moderada. Destrabeculação moderada. } \\
\text { Rim: Congestão moderada. }\end{array}$ & IIndeterminado. & Encalhe. \\
\hline 36 & $\begin{array}{l}\text { Kogia breviceps } \\
\text { Fêmea, adulta } \\
\text { CT: } 280 \mathrm{~cm}\end{array}$ & Histopatológico: Coloração H.E. & $\begin{array}{l}\text { Pele: Paniculite parasitária por larva de cestóide. } \\
\text { Pulmão: Congestão moderada. Hemorragia severa. } \\
\text { Figado: Congestão severa. Degeneração macro e microgoticular moderada. Hemorragia focal } \\
\text { coalescente, moderada a severa. Destrabeculação severa. } \\
\text { Baço: Linfocitólise centro-folicular moderada. }\end{array}$ & $\begin{array}{l}\text { Respiratório, asfixia, suspeita. } \\
\text { Quadro compativel com captura. }\end{array}$ & Encontrado morto junto ao Caso No. 42. \\
\hline 37 & $\begin{array}{l}\text { Kogia breviceps } \\
\text { Fêmea, jovem } \\
\text { CT: } 200 \mathrm{~cm}\end{array}$ & Histopatológico: Coloração H.E. & $\begin{array}{l}\text { Pulmão: Extensas áreas de hemorragia e congestão moderadas a severas. } \\
\text { Presença de edema e fibrina moderados. } \\
\text { Figado: Lipidose severa. Congestão moderada. } \\
\text { Baço e linfonodo: Depleção linfóide moderada. Linfocitólise, centro-folicular, moderada. }\end{array}$ & Metabólico, estresse. & $\begin{array}{l}\text { Encalhou viva junto a uma fêmea de maior tamanho, } \\
\text { provavelmente sua mãe. Foi transferido para centro } \\
\text { de reabilitação, vindo a obbito no terceiro dia. }\end{array}$ \\
\hline 38 & $\begin{array}{l}\text { Steno bredanensis } \\
\text { Macho, adulto } \\
\text { CT: } 263 \mathrm{~cm}\end{array}$ & $\begin{array}{l}\text { Histopatológico: Coloração H.E. } \\
\text { Parasitológico } \\
\text { Bacteriológico }\end{array}$ & $\begin{array}{l}\text { Pelel: Dermatite, superficial, perivascular, papiloma. } \\
\text { Pulmão: Pneumonia, intersticial, crônica, multifocal, moderada. Carneificação multifocal. } \\
\text { Edema moderado. } \\
\text { Rim: cistos, múltiplos sititos. } \\
\text { Baço: Esplenite, parasitária, com exsudação mista, severa. }\end{array}$ & $\begin{array}{l}\text { Infeccioso, bacteriano, } \\
\text { Staphylococcus xylosus. }\end{array}$ & Encontrado morto boiando. \\
\hline 42 & $\begin{array}{l}\text { Pontoporia blainvillei } \\
\text { Macho, jovem } \\
\text { CT: } 98 \mathrm{~cm} \\
\text { Peso: } 12 \mathrm{~kg}\end{array}$ & Histopatológico: Coloração H.E. & $\begin{array}{l}\text { Pulmäo: Pneumonia, crônica, granulomatossa por C.E., multifical, moderada. Cristais de coles- } \\
\text { terol. Pneumonia, intersticial, aguda, multifocal, moderada. } \\
\text { Congestão e hemorragia moderadas. } \\
\text { Baç: Hiperplasia linfóide reativa. }\end{array}$ & Respiratório, asfixia. & Captura acidental em rede de pesca. \\
\hline 43 & $\begin{array}{l}\text { Sotalia fluviatilis } \\
\text { Macho, adulto } \\
\text { CT: } 196 \mathrm{~cm} \\
\text { Peso: N.R. }\end{array}$ & $\begin{array}{l}\text { Histopatológico: Coloração H.E. } \\
\text { Parasitológico } \\
\text { Bacteriológico }\end{array}$ & $\begin{array}{l}\text { Pulmão: Broncopneumonia, purulenta, difusa, moderada a severa. } \\
\text { Figado: Leucocitose, eosinofilica, sinusoidal. } \\
\text { Baço: Esplenite, eosinofilica, difusa, moderada. } \\
\text { Linfonodo mediastinica Linfadenite, eosinofilica, difusa, moderada a severa. }\end{array}$ & $\begin{array}{l}\text { Respiratório, pneumonia, parasitária, } \\
\text { Halocercus brasiliensis. }\end{array}$ & $\begin{array}{l}\text { Encontrado morto e encaminhado a instituição } \\
\text { de pesquisa. }\end{array}$ \\
\hline 45 & $\begin{array}{l}\text { Tursiops truncatus } \\
\text { Fêmea, jovem } \\
\text { CT: } 202 \mathrm{~cm}\end{array}$ & Histopatológico: Coloração H.E. & 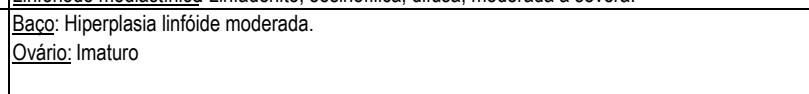 & Respiratório, asfixia. & Captura acidental em rede de pesca. \\
\hline 46 & $\begin{array}{l}\text { Stenella frontalis } \\
\text { Macho, adulto } \\
\text { CT: } 187 \mathrm{~cm} \\
\text { Peso: } 84 \mathrm{~kg}\end{array}$ & $\begin{array}{l}\text { Histopatológico: Coloraçōes H.E., } \\
\text { Gram, PAS e Zienh-Neelsen } \\
\text { Parasitológico } \\
\text { Bacteriológico }\end{array}$ & \begin{tabular}{|l} 
Pulmão: Edema, congestão, hemorragia e esfollação moderados. \\
Figado: Hiperplasia ductal moderada. Congestão moderada. Fibrose moderada. \\
Linfonodos: Hipoplasia linfóide severa, múttiplos sítios. Linfocitólise centro-folicular, \\
moderada, mútiplos sitios. Linfadenite piogranulomatosa bacteriana Gram negativa.
\end{tabular} & Respiratório, asfixia. & Captura acidental em rede de pesca. \\
\hline 47 & $\begin{array}{l}\text { Stenella frontalis } \\
\text { Macho, adulto } \\
\text { CT: } 208 \mathrm{~cm} \\
\text { Peso: } 110 \mathrm{~kg}\end{array}$ & $\begin{array}{l}\text { Histopatolólógico: Coloração H.E. } \\
\text { Parasitológico } \\
\text { Bacteriológico }\end{array}$ & 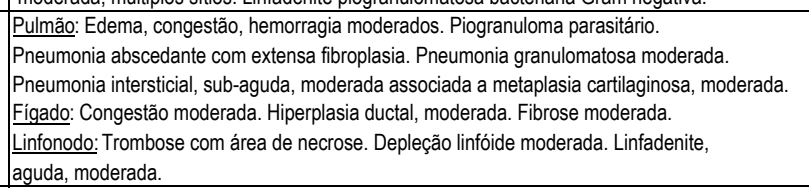 & Respiratório, asfixia. & \begin{tabular}{|l|} 
Captura acidental em rede de pesca. \\
\end{tabular} \\
\hline 48 & $\begin{array}{l}\text { Pontoporia blainvillei } \\
\text { Fêmea, filhote } \\
\text { CT: } 64 \mathrm{~cm} \\
\text { Peso: } 2,85 \mathrm{~kg}\end{array}$ & $\begin{array}{l}\text { Histopatológico: Coloraçãa H.E. } \\
\text { Bacteriológico }\end{array}$ & 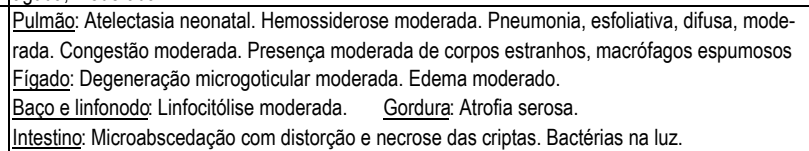 & $\begin{array}{l}\text { Respiratório, pneumonia, aspirativa. } \\
\text { Septicemia agônica. }\end{array}$ & $\begin{array}{l}\text { Encalhado vivo, foi encaminhado a centro de reabi- } \\
\text { litação. Foi submetido a antibioticoterapia e } \\
\text { alimentação forçada através de sondagem gástrica. } \\
\text { Permaneceu vivo por } 3 \text { dias, quando apresentou } \\
\text { diminuição da movimentação, tremores e morte. }\end{array}$ \\
\hline 49 & $\begin{array}{l}\text { Pontoporia blainvillei } \\
\text { Macho, jovem } \\
\text { CT: } 117 \mathrm{~cm} \\
\text { Peso: } 15 \mathrm{~kg}\end{array}$ & $\begin{array}{l}\text { Histopatológico: Coloraçōes H.E., } \\
\text { e Tricrômico de Masson. } \\
\text { Parasitológico } \\
\text { Bacteriológico }\end{array}$ & 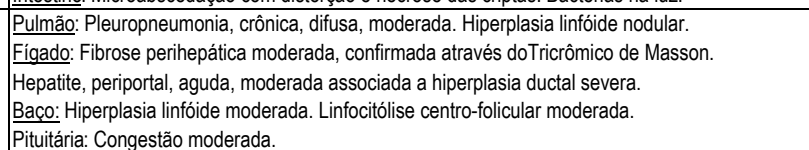 & Respiratório, asfixia. & Captura acidental em rede de pesca. \\
\hline 51 & $\begin{array}{l}\text { Sotalia fluviatilis } \\
\text { Macho, adulto } \\
\text { CT: } 180,5 \mathrm{~cm} \\
\text { Peso: } 78,5 \mathrm{~kg}\end{array}$ & $\begin{array}{l}\text { Histopatológico: Coloraçãa H.E. } \\
\text { Parasitológico }\end{array}$ & $\begin{array}{l}\text { Pulmäo: Pneumonia, intersticial, eosinofilica, difusa, moderada. } \\
\text { Pneumonia parasitária. }\end{array}$ & Respiratório, asfixia. & Captura acidental em rede de pesca. \\
\hline
\end{tabular}




\begin{tabular}{|c|c|c|c|c|c|}
\hline \multicolumn{2}{|c|}{ Cont. Tabela 3} & \multirow[b]{2}{*}{ Exames laboratorias } & \multirow[b]{2}{*}{ Diagnósticos morfológicos principais } & \multirow[b]{2}{*}{ Causa de morte } & \multirow{2}{*}{ Comentários } \\
\hline Caso No. & $\begin{array}{l}{ }^{*} \text { Caracteres } \\
\text { individuais }\end{array}$ & & & & \\
\hline 52 & $\begin{array}{l}\text { Pontoporia blainvillei } \\
\text { Macho, jovem } \\
\text { CT: } 102,8 \mathrm{~cm} \\
\text { Peso: } 11,7 \mathrm{~kg} \\
\end{array}$ & $\begin{array}{l}\text { Histopatológico: Coloraçẵo H.E. } \\
\text { Parasitológico }\end{array}$ & $\begin{array}{l}\text { Pulmão: Congestão e edema severos. } \\
\text { Pneumonia, crônica, granulomatosa por C.E., cristais de colesterol. }\end{array}$ & Respiratório, asfixia. & Captura acidental em rede de pesca. \\
\hline 53 & $\begin{array}{l}\text { Pontoporia blainvillei } \\
\text { Macho, jovem } \\
\text { CT: } 107,5 \mathrm{~cm} \\
\text { Peso: } 12,5 \mathrm{~kg}\end{array}$ & $\begin{array}{l}\text { Histopatológico: Coloraç̄ôs H.E., } \\
\text { Gram e PAS } \\
\text { Parasitológico }\end{array}$ & Pulmão: Congestão e edema moderados. Pneumonia focal piogranulomatosa. & Respiratório, asfixia. & Captura acidental em rede de pesca. \\
\hline 54 & $\begin{array}{l}\text { Pontoporia blainvillei } \\
\text { Macho, jovem } \\
\text { CT: } 97,2 \mathrm{~cm} \\
\text { Peso: } 11,5 \mathrm{~kg} \\
\end{array}$ & $\begin{array}{l}\text { Histopatológico: Coloração H.E. } \\
\text { Parasitológico }\end{array}$ & $\begin{array}{l}\text { Pulmão: Congestão severa. Pneumonia esfoliativa agônica. } \\
\text { Baço: Hiperplasia linfóide moderada, centros germinativos pronunciados. }\end{array}$ & Respiratório, asfixia. & Captura acidental em rede de pesca. \\
\hline 56 & $\begin{array}{l}\text { Pontoporia blainvillei } \\
\text { Macho, jovem } \\
\text { CT: } 115,5 \mathrm{~cm} \\
\text { Peso: } 19,1 \mathrm{~kg}\end{array}$ & $\begin{array}{l}\text { Histopatológico: Colorações H.E., } \\
\text { Gram, PAS, Tricrômico de Masson, } \\
\text { Azul de Toluidina e Giemsa. }\end{array}$ & $\begin{array}{l}\text { Pulmão: Congestão e hemorragia moderadas. } \\
\text { Intestino grossa. Hiperplasia do tecido linfóide associado. Enterite, linfoplasmocitária, } \\
\text { multifocal, moderada, com áreas de calcificação da sub-mucosa. Granulócitos eviden- } \\
\text { ciados através do Azul de Toluidina. Fibrose. }\end{array}$ & Respiratório, asfixia. & Captura acidental em rede de pesca. \\
\hline 57 & $\begin{array}{l}\text { Pontoporia blainvillei } \\
\text { Macho, jovem } \\
\text { CT: } 107,5 \mathrm{~cm} \\
\text { Peso: } 24,2 \mathrm{~kg}\end{array}$ & $\begin{array}{l}\text { Histopatológico: Coloraçōes H.E. e } \\
\text { Gram }\end{array}$ & $\begin{array}{l}\text { Pulmão: Congestão e edema moderados a severos. } \\
\text { Figado: Congestão moderada. } \\
\text { Linfonodo: Edema moderado. Hiperplasia linfóide moderada. Foliculos bem desenvol- } \\
\text { vidos, com centros germinativos exuberantes. } \\
\text { Baço: Hiperplasia linfóide moderada. Periesplenite por bactérias Gram negativas. }\end{array}$ & Respiratório, asfixia. & Captura acidental em rede de pesca. \\
\hline 58 & $\begin{array}{l}\text { Pontoporia blainvillei } \\
\text { Fêmea, jovem } \\
\text { CT: } 121,5 \mathrm{~cm} \\
\text { Peso: } 21,4 \mathrm{~kg} \\
\end{array}$ & Histopatológico: Coloração H.E. & $\begin{array}{l}\text { Pulmão: Congestão e hemorragia moderadas. } \\
\text { Figado: Congestão moderada. Hiperplasia ductal, moderada. Degeneração macro e } \\
\text { microgoticular moderada. Hemossiderose moderada. } \\
\text { Baç: Hipoplasia linfóide moderada. Linfocitólise moderada. }\end{array}$ & Respiratório, asfixia. & Captura acidental em rede de pesca. \\
\hline 59 & $\begin{array}{l}\text { Pontoporia blainvillei } \\
\text { Macho, jovem } \\
\text { CT: } 120,5 \mathrm{~cm} \\
\text { Peso: } 24,6 \mathrm{~kg}\end{array}$ & Histopatológico: Coloração H.E. & \begin{tabular}{|l|} 
Pulmão: Congestão, edema e hemorragia moderados. \\
Figado: Congestão moderada. \\
Rim: Congestão moderada. \\
Linfonodo: Perilinfadenite, aguda, moderada. Hiperplasia linfoidde moderada. \\
\end{tabular} & Respiratório, asfixia. & Captura acidental em rede de pesca. \\
\hline 60 & $\begin{array}{l}\text { Pontoporia blainvillei } \\
\text { Macho, jovem } \\
\text { CT: } 99,3 \mathrm{~cm} \\
\text { Peso: } 14,4 \mathrm{~kg} \\
\end{array}$ & $\begin{array}{l}\text { Histopatológico: Colorações H.E. e } \\
\text { Azul de Toluidina. }\end{array}$ & $\begin{array}{l}\text { Pulmão: Congestão moderada. } \\
\text { Figado: Congestão moderada. } \\
\text { Estômago: Peritonite, difusa, granulocitica, moderada. } \\
\text { Rim: Congestão moderada. }\end{array}$ & Respiratório, asfixia. & Captura acidental em rede de pesca. \\
\hline 61 & $\begin{array}{l}\text { Pontoporia blainvillei } \\
\text { Macho, jovem } \\
\text { CT: } 113,5 \mathrm{~cm} \\
\text { Peso: } 17 \mathrm{~kg} \\
\end{array}$ & Histopatológico: Coloração H.E. & $\begin{array}{l}\text { Pulmão: Congestão e hemorragia moderadas. } \\
\text { Baço: Hiperplasia linfóide moderada, com distensão dos centros germinativos e deslocamento } \\
\text { da arteriola centro-folicular. }\end{array}$ & Respiratório, asfixia. & Captura acidental em rede de pesca. \\
\hline 62 & $\begin{array}{l}\text { Pontoporia blainvillei } \\
\text { Macho, jovem } \\
\text { CT: } 114 \mathrm{~cm} \\
\text { Peso: } 21,4 \mathrm{~kg} \\
\end{array}$ & $\begin{array}{l}\text { Histopatológico: Colorações H.E., } \\
\text { Gram e PAS }\end{array}$ & $\begin{array}{l}\text { Pulmão: Congestão e edema moderados. } \\
\text { Pneumonia, crônica, granulomatosa, multifocal, por C.E., cristais de colesterol. } \\
\text { Estômago: Submucosa, piogranuloma, agente causal não conclusivo com Gram e PAS. } \\
\text { Baço: Hiperplasia linfóide moderada. }\end{array}$ & Respiratório, asfixia. & Captura acidental em rede de pesca. \\
\hline 63 & $\begin{array}{l}\text { Pontoporia blainvillei } \\
\text { Fêmea, adulta } \\
\text { CT: } 158 \mathrm{~cm} \\
\text { Peso: } 40,6 \mathrm{~kg} \\
\end{array}$ & Histopatológico: Coloração H.E. & $\begin{array}{l}\text { Pulmão: Congestão moderada. } \\
\text { Intestino: Enterite, submucosa, crônica, difusa, moderada, predominantemente mononuclear } \\
\text { com alguns granulócitos. }\end{array}$ & Respiratório, asfixia. & Captura acidental em rede de pesca. \\
\hline 64 & $\begin{array}{l}\text { Pontoporia blainvillei } \\
\text { Macho, jovem } \\
\text { CT: } 118 \mathrm{~cm} \\
\text { Peso: } 18 \mathrm{~kg}\end{array}$ & $\begin{array}{l}\text { Histopatológico: Coloraçōes H.E., } \\
\text { Gram, PAS, Ziehl-Neelsen e Tricrô- } \\
\text { mico de Masson. }\end{array}$ & $\begin{array}{l}\text { Pulmãa: Congestão, edema e hemorragia moderados. } \\
\text { Figado: Fibrose, moderada. } \\
\text { Baç: Fibrose, moderada a severa. Hipoplasia linfóide, severa. Linfocitólise moderada. } \\
\text { Fibrose confirmada através da coloraçăo de Masson. } \\
\text { Intestino: Enterte, plasmocitária, difusa, moderada. } \\
\text { Linfonodo: Linfadenite, piogranulomatosa, multifocal, moderada. } \\
\end{array}$ & Respiratório, asfixia. & Captura acidental em rede de pesca. \\
\hline 65 & $\begin{array}{l}\text { Pontoporia blainvillei } \\
\text { Macho, adulto } \\
\text { CT: } 132,5 \mathrm{~cm} \\
\text { Peso: } 27,8 \mathrm{~kg}\end{array}$ & Histopatológico: Coloração H.E. & \begin{tabular}{|l} 
Pulmão: Congestão, edema e hemorragia moderado a severos. \\
Pneumonia, crônica, granulomatosa por C.E., cristais de colesterol. \\
Figado: Congestão moderada. \\
Baço: Hiperplasia linfóide reativa, linfocitólise individual, multifocal, \\
moderada.
\end{tabular} & Respiratório, asfixia. & Captura acidental em rede de pesca. \\
\hline
\end{tabular}




\begin{tabular}{|c|c|c|c|c|c|}
\hline \multicolumn{2}{|c|}{ Cont. Tabela 3} & \multirow[b]{2}{*}{\begin{tabular}{|l|} 
Exames laboratorias \\
\end{tabular}} & \multirow[b]{2}{*}{ Diagnósticos morfológicos principais } & \multirow[b]{2}{*}{ Causa de morte } & \multirow[b]{2}{*}{ Comentários } \\
\hline Caso No. & $\begin{array}{l}{ }^{*} \text { Caracteres } \\
\text { individuais }\end{array}$ & & & & \\
\hline 66 & $\begin{array}{l}\text { Pontoporia blainvillei } \\
\text { Fêmea, jovem } \\
\text { CT: } 120 \mathrm{~cm} \\
\text { Peso: } 20 \mathrm{~kg}\end{array}$ & Histopatológico: Coloraçăo H.E. & $\begin{array}{l}\text { Pulmẫo: Congestão, edema e hemorragia moderados. } \\
\text { Figado: Congestão moderada. }\end{array}$ & Respiratório, asfixia. & Captura acidental em rede de pesca. \\
\hline 67 & $\begin{array}{l}\text { Pontoporia blainvillei } \\
\text { Macho, jovem } \\
\text { CT: } 125 \mathrm{~cm} \\
\text { Peso: } 21,8 \mathrm{~kg}\end{array}$ & $\begin{array}{l}\text { Histopatológico: Coloraçôes H.E., } \\
\text { Gram, PAS e Ziehl-Neelsen }\end{array}$ & $\begin{array}{l}\text { Pulmão: Congestão, edema e hemorragia severos, com descamação celular para o } \\
\text { interior dos alvéolos. } \\
\text { Baç: Hiperplasia linfóide severa. Linfocitólise individual moderada. } \\
\text { Linfonodo: Linfadenite piogranulomatosa multifocal moderada. Piogranuloma de origem } \\
\text { não evidente, apesar do encontro de poucas estruturas Gram negativas. } \\
\text { Rim: Congestão moderada. }\end{array}$ & Respiratório, asfixia. & Captura acidental em rede de pesca. \\
\hline 68 & $\begin{array}{l}\text { Pontoporia blainvillei } \\
\text { Macho, jovem } \\
\text { CT: } 121 \mathrm{~cm} \\
\text { Peso: } 19 \mathrm{~kg} \\
\end{array}$ & Histopatológico: Coloração H.E. & \begin{tabular}{|l|} 
Pulmäo: Congestão e hemorragia moderadas. \\
Baço: Hiperplasia linfóide moderada.
\end{tabular} & Respiratório, asfixia. & Captura acidental em rede de pesca. \\
\hline 69 & $\begin{array}{l}\text { Pontoporia blainvillei } \\
\text { Fêmea, jovem } \\
\text { CT: } 111,1 \mathrm{~cm} \\
\text { Peso: } 16,6 \mathrm{~kg} \\
\end{array}$ & Histopatológico: Coloração H.E. & \begin{tabular}{|l|} 
Pulmão: Congestão moderada. \\
Figado: Congestão moderada a severa. \\
Baço: Hiperplasia linfóide moderada. Linfocitólise difusa moderada.
\end{tabular} & Respiratório, asfixia. & Captura acidental em rede de pesca. \\
\hline 70 & $\begin{array}{l}\text { Pontoporia blainvillei } \\
\text { Fêmea, jovem } \\
\text { CT: } 94 \mathrm{~cm} \\
\text { Peso: } 11,6 \mathrm{~kg} \\
\end{array}$ & Histopatológico: Coloração H.E. & $\begin{array}{l}\text { Pulmão: Congestão e hemorragia moderadas a severas. } \\
\text { Baç:: Hiperplasia linfóide moderada. }\end{array}$ & Respiratório, asfixia. & Captura acidental em rede de pesca. \\
\hline 71 & $\begin{array}{l}\text { Pontoporia blainvillei } \\
\text { Macho, jovem } \\
\text { CT: } 120,2 \mathrm{~cm} \\
\text { Peso: } 23 \mathrm{~kg} \\
\end{array}$ & Histopatológico: Coloração H.E. & $\begin{array}{l}\text { Pulmão: Congestão, edema e hemorragia moderado a severos. } \\
\text { Presença de colônias bacterianas, terminal, mútiplos sitios. } \\
\text { Linfonodos hiperreativos, com centros germinativos. }\end{array}$ & Respiratório, asfixia. & Captura acidental em rede de pesca. \\
\hline 72 & $\begin{array}{l}\text { Pontoporia blainvillei } \\
\text { Macho, jovem } \\
\text { CT: } 125 \mathrm{~cm} \\
\text { Peso: } 26 \mathrm{~kg}\end{array}$ & $\begin{array}{l}\text { Histopatológico: Coloraçôes H.E., } \\
\text { Alcian Blue. }\end{array}$ & $\begin{array}{l}\text { Pulmão: Pneumonia, catarral, moderada. Congestão e hemorragia moderadas. } \\
\text { Muco videnciado através da coloração de Alcian Blue. }\end{array}$ & Respiratório, asfixia. & Captura acidental em rede de pesca. \\
\hline 73 & $\begin{array}{l}\text { Pontoporia blainvillei } \\
\text { Macho, jovem } \\
\text { CT: } 115 \mathrm{~cm} \\
\text { Peso: } 19,8 \mathrm{~kg} \\
\end{array}$ & Histopatológico: Coloração H.E. & $\begin{array}{l}\text { Pulmão: Congestão e hemorragia moderadas a severas. } \\
\text { Figado: Congestão moderada. }\end{array}$ & Respiratório, asfixia. & $\begin{array}{l}\text { Captura acidental em rede de pesca. } \\
\text { Devido à autólise não foi possivel } \\
\text { determinar outras alterações. }\end{array}$ \\
\hline 74 & $\begin{array}{l}\text { Pontoporia blainvillei } \\
\text { Fêmea, adulta } \\
\text { CT: } 143,3 \mathrm{~cm} \\
\text { Peso: } 29 \mathrm{~kg}\end{array}$ & $\begin{array}{l}\text { Histopatológico: Coloraçōes H.E., } \\
\text { Gram, PAS e Ziehl-Neelsen }\end{array}$ & $\begin{array}{l}\text { Pulmão: Congestão e hemorragia moderadas. } \\
\text { Figado: Congestão moderada a severa com áreas de destrabeculação dos hepatócitos. }\end{array}$ & Respiratório, asfixia. & $\begin{array}{l}\text { Captura acidental em rede de pesca. } \\
\text { Colorações especificas foram pouco } \\
\text { conclusivas devido à falta de material. }\end{array}$ \\
\hline 75 & $\begin{array}{l}\text { Pontoporia blainvillei } \\
\text { Fêmea, jovem } \\
\text { CT: } 118,7 \mathrm{~cm} \\
\text { Peso: } 17,1 \mathrm{~kg} \\
\end{array}$ & Histopatológico: Coloração H.E. & \begin{tabular}{|l} 
Pulmão: Autólise. \\
Intestino: Microabscedação com distorção das criptas.
\end{tabular} & Respiratório, asfixia. & Captura acidental em rede de pesca. \\
\hline 76 & $\begin{array}{l}\text { Pontoporia blainvillei } \\
\text { Fêmea, jovem } \\
\text { CT: } 122 \mathrm{~cm} \\
\text { Peso: } 22 \mathrm{~kg} \\
\end{array}$ & Histopatológico: Coloração H.E. & Pulmão: Congestão, edema e hemorragia moderados. & Respiratório, asfixia. & Captura acidental em rede de pesca. \\
\hline 77 & $\begin{array}{l}\text { Pontoporia blainvillei } \\
\text { Macho, jovem } \\
\text { CT: } 109,4 \mathrm{~cm} \\
\text { Peso: } 16,6 \mathrm{~kg}\end{array}$ & Histopatológico: Coloração H.E. & $\begin{array}{l}\text { Pulmão: Congestão e hemorragia moderadas a severas. Edema moderado. } \\
\text { Intestino: Enterite, plasmocitária, difusa, moderada. Distorção das criptas. }\end{array}$ & Respiratório, asfixia. & Captura acidental em rede de pesca. \\
\hline 78 & $\begin{array}{c}\text { Pontoporia blainvillei } \\
\text { Macho, adulto jovem } \\
\text { CT: } 123,5 \mathrm{~cm} \\
\text { Peso: } 24,5 \mathrm{~kg} \\
\end{array}$ & Histopatológico: Coloração H.E. & $\begin{array}{l}\text { Pulmão: Congestão, edema e hemorragia moderados. } \\
\text { Figado: Congestão moderada. }\end{array}$ & Respiratório, asfixia. & Captura acidental em rede de pesca. \\
\hline 79 & $\begin{array}{l}\text { Pontoporia blainvillei } \\
\text { Fêmea, jovem } \\
\text { CT: } 120,5 \mathrm{~cm} \\
\text { Peso: } 20 \mathrm{~kg} \\
\end{array}$ & Histopatológico: Coloração H.E. & Pulmão: Congestão e hemorragia moderadas. & Respiratório, asfixia. & Captura acidental em rede de pesca. \\
\hline
\end{tabular}


Cont. Tabela 3

\begin{tabular}{|c|c|c|c|c|c|}
\hline \multirow[b]{2}{*}{ Caso No. } & \multirow{2}{*}{$\begin{array}{l}{ }^{*} \text { Caracteres } \\
\text { individuais }\end{array}$} & \multirow{2}{*}{\multicolumn{2}{|c|}{ Exames Jaboratorias }} & \multirow{2}{*}{ Causa de morte } & \multirow[b]{2}{*}{ Comentários } \\
\hline & & & \begin{tabular}{|c|c|c|} 
Diagnósticos morfológicos principais \\
\end{tabular} & & \\
\hline 80 & $\begin{array}{l}\text { Pontoporia blainvillei } \\
\text { Macho, adulto } \\
\text { CT: } 132,5 \mathrm{~cm} \\
\text { Peso: } 27 \mathrm{~kg}\end{array}$ & Histopatológico: Coloração H.E. & Pulmão: Congestão, edema e hemorragia moderados. & Respiratório, asfixia. & Captura acidental em rede de pesca. \\
\hline 81 & $\begin{array}{l}\text { B. acutorostrata } \\
\text { Fêmea, jovem }\end{array}$ & Histopatológico: Coloração H.E. & Ovário: Imaturo & Indeterminado. & $\begin{array}{l}\text { Encontrado morto durante monitoramento de praia. } \\
\text { Causa de morte não evidente devido à falta de } \\
\text { orrgäos encaminhados para análise. }\end{array}$ \\
\hline 85 & $\begin{array}{l}\text { Pontoporia blainvillei } \\
\text { Macho, adulto } \\
\text { CT: } 123,3 \mathrm{~cm} \\
\text { Peso: } 25 \mathrm{~kg}\end{array}$ & Histopatológico: Coloração H.E. & \begin{tabular}{|l} 
Pulmão: Autólise. \\
Figado: Congestão moderada. \\
Rim: Congestão moderada.
\end{tabular} & Respiratório, asfixia. & $\begin{array}{l}\text { Captura acidental em rede de pesca. } \\
\text { Devido à autólise não foi possivel determinar } \\
\text { outras alteraçōes. }\end{array}$ \\
\hline 86 & $\begin{array}{l}\text { Pontoporia blainvillei } \\
\text { Fêmea, adulta } \\
\text { CT: } 125,5 \mathrm{~cm} \\
\text { Peso: } 24 \mathrm{~kg}\end{array}$ & Histopatológico: Coloração H.E. & Pulmão: Congestão e hemorragia moderada a severas. & Respiratório, asfixia. & Captura acidental em rede de pesca. \\
\hline 87 & $\begin{array}{l}\text { Pontoporia blainvillei } \\
\text { Fêmea, adulta } \\
\text { CT: } 135,5 \mathrm{~cm} \\
\text { Peso: } 29 \mathrm{~kg}\end{array}$ & Histopatológico: Coloração H.E. & $\begin{array}{l}\text { Pulmão: Congestão severa. Hemorragia, multifocal, severa. Edema moderado. Derrame } \\
\text { fibrinoso difuso. Pneumonia esfoliativa constituida por grande quantidade de macrófagos } \\
\text { espumosos no interior dos alvéolos, associada à fetalização pulmonar multifocal. } \\
\text { Figado: Congestão moderada. } \\
\text { Rim. Congestão moderada. }\end{array}$ & Respiratório, asfixia. & Captura acidental em rede de pesca. \\
\hline 88 & $\begin{array}{l}\text { Stenella clymene } \\
\text { Fêmea, adulta } \\
\text { CT: } 189,2 \mathrm{~cm} \\
\text { Peso: } 71,3 \mathrm{~kg}\end{array}$ & $\begin{array}{l}\text { Histopatológico: Colorações H.E., } \\
\text { Gram, Giemsa, PAS e Grocott }\end{array}$ & $\begin{array}{l}\text { Pulmão: Presença de parasitas. Congestão moderada. Presença moderada de fibrina e exsu- } \\
\text { dação granulocitica em árvore respiratória. } \\
\text { Linfonodo: Linfadenite, piogranulomatosa, coalescente, moderada. } \\
\text { Esôfago: Exsudação diftérica, severa. } \\
\text { Medula cervical: Meningomielite não supurativa severa. }\end{array}$ & Infeccioso, agente indeterminado. & $\begin{array}{l}\text { Encalhado vivo, apresentava dificuldade de } \\
\text { natação e flutuabilidade, apresentou tremores e } \\
\text { morte } 24 \text { hs após o encalhe. }\end{array}$ \\
\hline 90 & $\begin{array}{l}\text { Pontoporia blainvillei } \\
\text { Macho }\end{array}$ & $\begin{array}{l}\text { Histopatológico: Coloraçōes H.E., } \\
\text { Gram, Giemsa e Sudan Black }\end{array}$ & 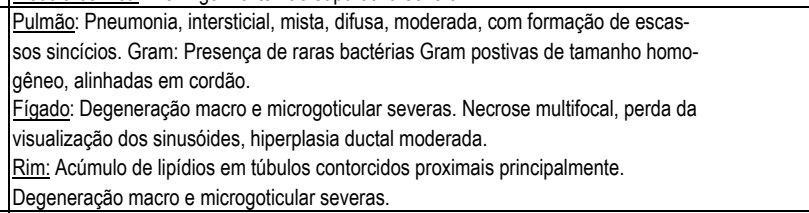 & Metabólico, lipidose hepato-renal. & Encaminhado morto ao centro de reabilitação. \\
\hline 91 & $\begin{array}{l}\text { Pontoporia blainvillei } \\
\text { Macho, jovem } \\
\text { CT: } 76,5 \mathrm{~cm} \\
\text { Peso: } 8,7 \mathrm{~kg}\end{array}$ & Histopatológico: Coloração H.E. & $\begin{array}{l}\text { Pulmäo: Edema e congestäo moderados a severos. Pneumonia, intersticial, sub-aguda, mode- } \\
\text { rada. Pneumonia esfoliativa moderada. Pneumonia aspirativa com grande quantidade de mate- } \\
\text { rial particulado nos espaços alveolares. } \\
\text { Linfonodo: Depleçâao linfoidde, moderada. Linfadenite, granulocitica, hemorrágica, moderada. }\end{array}$ & Respiratório, pneumonia aspirativa. & $\begin{array}{l}\text { Alimentação forçada através de sondagem gástrica. } \\
\text { Óbito em centro de reabilitação. }\end{array}$ \\
\hline 92 & $\begin{array}{l}\text { Pontoporia blainvillei } \\
\text { Fêmea, adulta } \\
\text { CT: } 124 \mathrm{~cm} \\
\text { Peso: } 25,5 \mathrm{~kg}\end{array}$ & Histopatológico: Coloração H.E. & $\begin{array}{l}\text { Pulmäo: Pneumonia, crônica, granulomatosa por C.E., multifical, cristais de colesterol. } \\
\text { moderada. Consolidaçăo pulmonar, congestâo e hemorragia severas. }\end{array}$ & Respiratório, asfixia. & Captura acidental em rede de pesca. \\
\hline 93 & $\begin{array}{l}\text { Pontoporia blainvillei } \\
\text { Macho, jovem } \\
\text { CT: } 121 \mathrm{~cm} \\
\text { Peso: } 18,5 \mathrm{~kg} \\
\end{array}$ & Histopatológico: Coloração H.E. & $\begin{array}{l}\text { Pulmão: Congestão e hemorragia severas. } \\
\text { Figado: Congestão moderada. }\end{array}$ & Respiratório, asfixia. & Captura acidental em rede de pesca. \\
\hline 94 & $\begin{array}{l}\text { Stenella frontalis } \\
\text { Fêmea, adulta } \\
\text { CT: } 188 \mathrm{~cm} \\
\text { Peso: } 88 \mathrm{~kg}\end{array}$ & Histopatológico: Coloração H.E. & \begin{tabular}{|l} 
Pulmão: Pneumonia, intersticial, moderada. \\
Baço: Hiperplasia linfóide reativa. Congestão, moderada.
\end{tabular} & Respiratótrio, pneumonia intersticial. & Encontrado morto durante monitoramento de praia. \\
\hline 95 & $\begin{array}{l}\text { Pontoporia blainvillei } \\
\text { Fêmea }\end{array}$ & Histopatológico: Coloraçãa H.E. & Pulmão: Pneumonia, intersticial, moderada a severa. & \begin{tabular}{|l|l} 
Respiratótrio, pneumonia, intersticialal. \\
\end{tabular} & Encontrado morto durante monitoramento de praia. \\
\hline 98 & $\begin{array}{l}\text { Pontoporia blainvillei } \\
\text { Macho, jovem } \\
\text { CT: } 93,3 \mathrm{~cm} \\
\text { Peso: } 8,2 \mathrm{~kg}\end{array}$ & $\begin{array}{l}\text { Histopatológico: Colorações H.E., } \\
\text { Tricrómico de Masson e Perls. } \\
\text { Parasitológico } \\
\text { Bacteriológico }\end{array}$ & $\begin{array}{l}\text { Pulmão: Pleuropneumonia, crônica, difusa, moderada a severa. Pneumonia, crônica, } \\
\text { granulomatosa por C.E., multifocal, coalescente, moderada. Cristais de colesterol. } \\
\text { Figado: Congestäo moderada, extensa área delimitada necrótica contendo hiperplasia } \\
\text { ductal exuberante, material fibrilar homogêneo com fibroplasia insipiente e hemossiderose. } \\
\text { Baç: Hiperplasia linfóide reativa. } \\
\text { Pênis: Hematoma associado a balanite moderada. } \\
\text { Linfonodo: Linfadenite, difusa, moderada, múltiplos sitios. } \\
\text { Olho: Catarata. }\end{array}$ & Respiratório, asfixia. & Captura acidental em rede de pesca. \\
\hline
\end{tabular}


Cont. Tabela 3

\begin{tabular}{|c|c|c|c|c|c|}
\hline \multirow[b]{2}{*}{ Caso No. } & \multirow{2}{*}{$\begin{array}{l}{ }^{*} \text { Caracteres } \\
\text { individuais }\end{array}$} & \multirow{2}{*}{\multicolumn{2}{|c|}{ Dianóśsticos morfóágicos nrincinzis }} & & \\
\hline & & Exames laboratorias & & $\begin{array}{l}\text { Causa de morte } \\
\end{array}$ & $\begin{array}{r}\text { Comentários } \\
\end{array}$ \\
\hline 101 & $\begin{array}{c}\text { Pontoporia blainvillei } \\
\text { Fêmea, jovem } \\
\text { CT: } 103 \mathrm{~cm} \\
\text { Peso: } 14,4 \mathrm{~kg} \\
\end{array}$ & Histopatológico: Coloração H.E. & $\begin{array}{l}\text { Pulmão: Congestão e hemorragia moderadas. Bactérias de putrefaçãa, parcialmente } \\
\text { autolisado. } \\
\text { Figado: Congestão moderada a severa, parcialmente autolisado. }\end{array}$ & Respiratório, asfixia. & Captura acidental em rede de pesca. \\
\hline 102 & $\begin{array}{l}\text { Stenella coeruleoalba } \\
\text { Macho, adulto } \\
\text { CT: } 242,5 \mathrm{~cm} \\
\text { Peso: } 131 \mathrm{~kg} \\
\end{array}$ & Histopatológico: Coloração H.E. & $\begin{array}{l}\text { Pulmão: Congestão, edema e hemorragia moderados. } \\
\text { Baço: Hiperplasia linfóide moderada com áreas de coalescência. Linfocitólise, centro- } \\
\text { folicular, moderada. }\end{array}$ & Respiratório, asfixia. & Captura acidental em rede de pesca. \\
\hline 105 & $\begin{array}{c}\text { Pontoporia blainvillei } \\
\text { Fêmea, jovem } \\
\text { CT: } 116,3 \mathrm{~cm} \\
\text { Peso: } 19,3 \mathrm{~kg} \\
\end{array}$ & Histopatológico: Coloração H.E. & \begin{tabular}{|l|} 
Pulmão: Congestão moderada, edema severo. \\
Figado: Congestão moderada, autólise avançada. \\
Rim: Congestão moderada, áreas focais de hemorragia.
\end{tabular} & Respiratótio, asfixia. & Captura acidental em rede de pesca. \\
\hline 106 & $\begin{array}{l}\text { Pontoporia blainvillei } \\
\text { Fêmea, adulta } \\
\text { CT: } 141 \mathrm{~cm} \\
\text { Peso: } 33,3 \mathrm{~kg}\end{array}$ & Histopatológico: Coloração H.E. & \begin{tabular}{|l} 
Pulmão: Congestão moderada, edema severo. \\
Figado: Congestão moderada, autólise avançada. \\
Rim: Congestão moderada, áreas focais de hemorragia.
\end{tabular} & Respiratório, asfixia. & Captura acidental em rede de pesca. \\
\hline
\end{tabular}

Legenda:

* Foram relatadas as informaçōes disponibilizadas pelos coletores.

C.E.: Corpo estranho

\section{Nomes cientificos e nomes comuns dos animais apresentados:}

Balaenoptera acutorostrata: baleia-minke-anã

Kogia breviceps: cachalote-pigmeu

Kogia simus: cachalote-anão

Pontoporia blainvillei: franciscana ou toninha

Sotalia fluviatilis: boto cinza ou tucuxi

Stenella clymene: golfinho-climene

Stenella frontalis: golfinho-pintado-do

Steno bredanensis: golfinho-de-dentes-rugosos 
Tabela 4. Distribuição dos caracteres individuais, exames laboratoriais realizados, diagnósticos morfológicos principais e causas de morte observados em pinípedes em função do Caso No. Sudeste e Sul do Brasil, 1997 a 2002.

\begin{tabular}{|c|c|c|c|c|c|}
\hline Caso No. & $\begin{array}{l}{ }^{*} \text { Caracteres } \\
\text { individuais }\end{array}$ & Exames laboratorias & $\begin{array}{l}\text { Diagnósticos morfológicos principais } \\
\end{array}$ & Causa de morte & Comentários \\
\hline 1 & $\begin{array}{l}\text { Eumetopias jubatus } \\
\text { Fêmea, adulta }\end{array}$ & $\begin{array}{l}\text { Histopatológico: Colorações H.E., } \\
\text { Vermelho Congo, Tricrômico } \\
\text { de Masson }\end{array}$ & $\begin{array}{l}\text { Pulmão: B Bronquiectasia, fibrinohemorráaica, moderada. Congestão e hemorragia } \\
\text { moderadas. Presença de C.E. Pneumonia, aspirativa, agônica. Presença de parasitos } \\
\text { Metastrongilideos, áreas de consolidação e antracose multifocal. } \\
\text { Rim: Pielonefrite, sub-aguda, multifocal, coalescente, moderada. Congestão moderada. } \\
\text { Fibrose, periglomerular, moderada, evidenciada através do Tricrômico de Masson. } \\
\text { Baço: Hipoplasia linfoide moderada. }\end{array}$ & Urinário, pielononefrite. & $\begin{array}{l}\text { Indivíduo veio a óbito com suspeita de afecção } \\
\text { renal (Comunicaçẫo pessoal do méd. veterinário). } \\
\text { Animal de circo mantido na Av. Marginal Pinheiros. }\end{array}$ \\
\hline 6 & $\begin{array}{l}\text { Lobodon carcinophagus } \\
\text { Fêmea, jovem } \\
\text { CT: } 170 \mathrm{~cm} \\
\text { Peso: } 72,5 \mathrm{~kg}\end{array}$ & Histopatológico: Coloraçẵo H.E. & $\begin{array}{l}\text { Pulmão: Hemorragia alvéolo-bronquiolar coalescente, multifiocal, moderada a severa. } \\
\text { Figado: Congestäo severa. Autólise. } \\
\text { Baco: Hipoplasia linfóide moderada. Histiocitose moderada. } \\
\text { Linfonodor reativo com mútiplas cicatrizes. }\end{array}$ & Sindrome, colapso. & Encontrado morto durante monitoramento de praia. \\
\hline 13 & $\begin{array}{l}\text { Arctocephalus australis } \\
\text { Macho, jovem } \\
\text { CT: } 87 \mathrm{~cm} \\
\text { Peso: } 15 \mathrm{~kg}\end{array}$ & Histopatológico: Coloração H.E. & $\begin{array}{l}\text { Pulmão: Congestão e hemorragia, moderadas. Corpo estranho e bactérias na luz alveolar, } \\
\text { pneumonia aspirativa agônica. }\end{array}$ & Trauma, vandalismo, suspeita. & $\begin{array}{l}\text { Encontrado morto com fraturas ocasionadas } \\
\text { por tiros de "chumbinho". }\end{array}$ \\
\hline 14 & $\begin{array}{l}\text { Arctocephalus australis } \\
\text { Macho, jovem } \\
\text { CT: } 100 \mathrm{~cm} \\
\text { Peso: } 17 \mathrm{~kg}\end{array}$ & Histopatológico: Coloração H.E. & $\begin{array}{l}\text { Lingua: Necrose de Zenker acentuada. } \\
\text { Pulmão: Congestão e hemorragia, moderadas a severas. } \\
\text { Figado: Degeneração macro e microgoticular, multifocal, moderada. } \\
\text { Baço: Depleção linfóide, moderada. } \\
\text { Rim: Congestão moderada, inicio de gota. } \\
\end{array}$ & Metabólico, estresse. & $\begin{array}{l}\text { Já reabilitado, foi deixado por pescadores em jaula } \\
\text { sob o sol forte durante } 8 \text { horas. Foi reencaminhado } \\
\text { ao centro de reabilitação em choque. Foi feita apli- } \\
\text { cação de corticosteróide e fluidoterapia SC, vindo a } \\
\text { bobito horas depois. }\end{array}$ \\
\hline 16 & $\begin{array}{l}\text { Arctocephalus australis } \\
\text { Fêmea, jovem } \\
\text { CT: } 84 \mathrm{~cm} \\
\text { Peso: } 8,5 \mathrm{~kg} \\
\end{array}$ & Histopatológico: Coloração H.E. & $\begin{array}{l}\text { Pulmão: Congestão moderada. Pneumonia, intersticial, aguda, difusa, moderada. } \\
\text { Linfonodo: Hiperplasia linfóide associada a linfocitólise centro-folicular, moderadas. } \\
\text { Baço: Depleção linfóide, moderada. }\end{array}$ & Respiratório, pneumonia, intersticial. & Óbito em centro de reabilitação. \\
\hline 18 & $\begin{array}{l}\text { Arctocephalus tropicalis } \\
\text { Macho, adulto } \\
\text { CT: } 159,5 \mathrm{~cm} \\
\text { Peso: } 44 \mathrm{~kg}\end{array}$ & $\begin{array}{l}\text { Histopatológico: Colorações H.E. e } \\
\text { PAS } \\
\text { Bacteriológico }\end{array}$ & 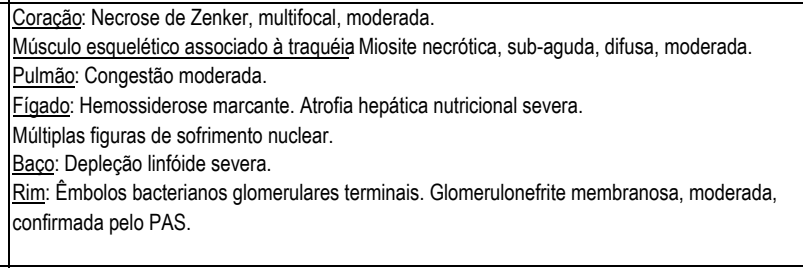 & Nutricional, caquexia. & $\begin{array}{l}\text { Foi transferido entre jardins zoológicos, para reabi- } \\
\text { itação. Ao ingresso apresentava caquexia, prostra- } \\
\text { ção, desidratação severa. Iniciou-se terapia de hi- } \\
\text { dratação, antibioticoterapia, e alimentação forçada } \\
\text { através de sonda gástrica. Após } 10 \text { dias alimentava- } \\
\text { se espontaneamente de peixe vivo de água doce, } \\
\text { obtido de lago contaminado. Toda a medicação foi } \\
\text { suspensa. Aos } 50 \text { dias do ingresso apresentou qua- } \\
\text { dro convulsivo agudo, vindo a óbito nessa ocasião. }\end{array}$ \\
\hline 28 & $\begin{array}{l}\text { Arctocephalus australis } \\
\text { Macho, jovem } \\
\text { Peso: } 11,6 \mathrm{~kg}\end{array}$ & Histopatológico: Coloração H.E. & $\begin{array}{l}\text { Baço: Hipoplasia linfóide severa. } \\
\text { Presença de parasitos anisaquideos em local indeterminado devido ao comprometimento } \\
\text { autolitico. }\end{array}$ & Metabólico, estresse. & $\begin{array}{l}\text { Ingressou em centro de reabilitacẵo com } \\
13 \mathrm{~kg} \text {, vindo a óbito } 4 \text { dias depois. }\end{array}$ \\
\hline 29 & $\begin{array}{l}\text { Arctocephalus australis } \\
\text { Fêmea, jovem } \\
\text { CT: } 91 \mathrm{~cm} \\
\text { Peso: } 11,8 \mathrm{~kg}\end{array}$ & Histopatológico: Coloração H.E. & $\begin{array}{l}\text { Pulmäo: Congestão moderada. Presença de parasitos Metastrongilidae, pneumonia parasitáría. } \\
\text { Pneumonia, intersticial, difusa, moderada a severa. } \\
\text { Rim: Pielonefrite, mista, moderada. Nefrite, intersticial, moderada. Esclerose glomerular mode- } \\
\text { rada. Glomerulonefrite membranoproliferativa, moderada. Cilindrúria proteinácea, moderada. } \\
\text { Glomerulonefrite linfoplasmocitária, moderada. }\end{array}$ & Respiratótrio, pneumonia intersticial. & $\begin{array}{l}\text { Óbito em centro de reabilitação } 3 \text { dias após o } \\
\text { ingresso. }\end{array}$ \\
\hline 31 & $\begin{array}{l}\text { Arctocephalus australis } \\
\text { Macho, filhote } \\
\text { CT: } 83,5 \mathrm{~cm} \\
\text { Peso: } 7,9 \mathrm{~kg} \\
\end{array}$ & Histopatológico: Coloração H.E. & Baço e linfonodo: Hipoplasia linfóide, severa. & Metabólico, estresse. & $\begin{array}{l}\text { Óbito em centro de reabilitaçãa } 17 \text { dias após o in- } \\
\text { gresso. Ingressou com } 10 \mathrm{~kg} \text {, apresentando esterto- } \\
\text { res, feita antibioticoterapia (Flotril - } 5 \text { dias). Vermifu- } \\
\text { gação } 10 \text { dias após ingresso. }\end{array}$ \\
\hline 32 & $\begin{array}{l}\text { Arctocephalus australis } \\
\text { Macho, jovem } \\
\text { CT: } 103 \mathrm{~cm} \\
\text { Peso: } 12 \mathrm{~kg}\end{array}$ & Histopatológico: Coloração H.E. & Baço: Hipoplasia linfóide severa. & Metabólico, estresse. & $\begin{array}{l}\text { Encontrado por pessoa do público próximo à agua } \\
\text { em estado de choque. Permaneceu inconsciente } \\
\text { durante o transporte. Ao ingressar em centro de rea- } \\
\text { bilitação: Corticóide IM, hidratação SC, descanso. } \\
\text { Recebeu nova hidrataçãa SC. Óbito no mesmo dia. }\end{array}$ \\
\hline 33 & $\begin{array}{l}\text { Arctocephalus australis } \\
\text { Macho, filhote } \\
\text { CT: } 76 \mathrm{~cm} \\
\text { Peso: } 5,5 \mathrm{~kg} \\
\end{array}$ & Histopatológico: Coloração H.E. & $\begin{array}{l}\text { Pulmäo: Pneumonia, intersticialal, difusa, moderada. Congestão moderada. } \\
\text { Baç: Hipoplasia linfoide, moderada. Lise centrofolicular, moderada } \\
\text { Timo: Rarefaçăo de células T, moderada. }\end{array}$ & Metabólico, estresse. & $\begin{array}{l}\text { Óbito em centro de reabilitação na primeira noite } \\
\text { após o ingresso. Condição corporal regular. }\end{array}$ \\
\hline
\end{tabular}




\begin{tabular}{|c|c|c|c|c|c|}
\hline \multicolumn{2}{|c|}{ Cont. Tabela 4} & \multirow[b]{2}{*}{ Exames laboratorias } & \multirow[b]{2}{*}{\begin{tabular}{|l|} 
Diagnósticos morfológicos principais \\
\end{tabular}} & \multirow[b]{2}{*}{ Causa de morte } & \multirow[b]{2}{*}{\begin{tabular}{|c|} 
Comentários \\
\end{tabular}} \\
\hline Caso No. & $\begin{array}{l}{ }^{*} \text { Caracteres } \\
\text { individuais }\end{array}$ & & & & \\
\hline 39 & $\begin{array}{l}\text { Arctocephalus tropicalis } \\
\text { Macho, jovem } \\
\text { CT: } 133,5 \mathrm{~cm} \\
\text { Peso: } 27,4 \mathrm{~kg}\end{array}$ & $\begin{array}{l}\text { Histopatológico: Coloração H.E. } \\
\text { Bacteriológico }\end{array}$ & 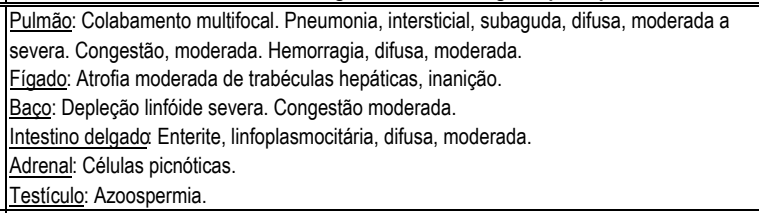 & Respiratório, pneumonia, intersticial. & $\begin{array}{l}\text { Ingressou em centro de reabilitação apresentando } \\
\text { hipertermia, desidratacãao moderada e mucosas } \\
\text { normocoradas. Atitude agressiva e ativa. Aos } 14 \\
\text { dias de ingresso apresentou emagrecimento } \\
\text { acentuado. Aos } 26 \text { dias continuava deteriorando, } \\
\text { diarréia intensa, prostração e início de medicaçăo } \\
\text { suporte. Óbito aos } 28 \text { dias de ingresso. }\end{array}$ \\
\hline 40 & $\begin{array}{l}\text { Arctocephalus australis } \\
\text { Macho, jovem } \\
\text { CT: } 88 \mathrm{~cm} \\
\text { Peso: } 13 \mathrm{~kg}\end{array}$ & Histopatológico: Coloração H.E. & Pulmão: Parasitas no espaço alveolar. Congestão moderada. & Fisico, queimadura. & $\begin{array}{l}\text { Aos } 5 \text { dias de ingresso em centro de reabilittacãa } \\
\text { queimou-se em aquecedor elétrico deixado no } \\
\text { recinto. Queimaduras nas nadadeiras anteriores. } \\
\text { Após } 4 \text { dias apresentou dispnéia, taquicardia, } \\
\text { choque e morte. Individuo cego. }\end{array}$ \\
\hline 41 & $\begin{array}{l}\text { Arctocephalus tropicalis } \\
\text { Macho, adulto } \\
\text { CT: } 159 \mathrm{~cm} \\
\text { Peso: } 50 \mathrm{~kg}\end{array}$ & $\begin{array}{l}\text { Histopatológico: Coloraçōes H.E., } \\
\text { Gram, Giemsa, PAS e Tricrômico } \\
\text { de Masson } \\
\text { Bacteriológico }\end{array}$ & $\begin{array}{l}\text { Pulmão: Pneumonia, fibrinosa, difusa, moderada a severa associada a extensas } \\
\text { áreas de exsudação fibrinosa, carneificação e piogranulomas multifocais. } \\
\text { Tricrômico de Masson: positivo para a carneificação pulmonar; PAS: presença de } \\
\text { concreçães mucóides. Giemsa: População predominantemente mononuclear de células } \\
\text { grandes com núcleos ovalados e citoplasma basofilico. } \\
\text { Baço: Hipoplasia linfóide moderada. } \\
\text { Linfonodo: Linfadenite, difusa, moderada associada à hipoplasia linfoide e histiocitose. } \\
\text { Linfadenite piogranulomatosa. } \\
\text { lntestino: Enterite, crônica, difusa, moderada a severa com marcante distorção das } \\
\text { vilosidades. } \\
\text { Figado: Extensa fibrose. Hemossiderose, difusa, moderada. Congestão moderada. } \\
\text { Hiperplasia ductal moderada. Atrofia hepática, inanição. Destrabeculaçăo moderada. } \\
\text { Testiculo: Azoospermia. }\end{array}$ & $\begin{array}{l}\text { Respiratório, pneumonia, bacteriana, } \\
\text { Klebsiella pneumoniae. }\end{array}$ & $\begin{array}{l}\text { Resgatado por centro de reabilitaçãa. } \\
\text { Hipotermia }\left(36,3^{\circ} \mathrm{C}\right) \text {, desidratação, mucosas } \\
\text { hipocoradas, prostração, fezes pastosas. } \\
\text { Obbito } 48 \text { hs após o ingresso. }\end{array}$ \\
\hline 44 & $\begin{array}{l}\text { Otaria flavescens } \\
\text { Macho, adulto } \\
\text { Peso: } 380 \mathrm{~kg}\end{array}$ & \begin{tabular}{|l|} 
Histopatolóógico: Coloraçôes H.E. e \\
Tricrômico de Masson
\end{tabular} & 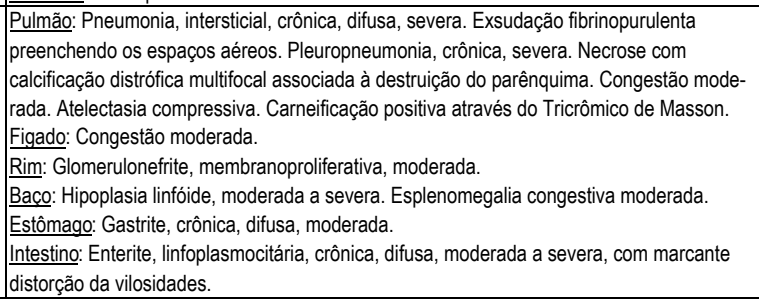 & Respiratório, pleuropneumonia. & Encontrado morto durante monitoramento de praia. \\
\hline 50 & $\begin{array}{l}\text { Leptonychotes weddellii } \\
\text { Fêmea, jovem } \\
\text { CT: } 149 \mathrm{~cm} \\
\text { Peso: } 75,8 \mathrm{~kg}\end{array}$ & Histopatológico: Coloração H.E. & $\begin{array}{l}\text { Pulmäo: Congestão moderada. } \\
\text { Figado: Hemossiderose periportal, moderada. } \\
\text { Baço: Hipoplasia linfóide moderada. Esplenomegalia congestiva. Presença moderada de } \\
\text { megacariócitos. Hematopoiese extra-medular, moderada. } \\
\text { Intestino delgado e cólon Enterite, linfoplasmocitária, difusa, moderada. } \\
\text { Linfonodo: Linfocitólise centro-folicular moderada. }\end{array}$ & Respiratório, asfixia. & Captura acidental em rede de pesca. \\
\hline 55 & $\begin{array}{l}\text { Arctocephalus tropicalis } \\
\text { Macho, adulto jovem } \\
\text { CT: } 146 \mathrm{~cm}\end{array}$ & $\begin{array}{l}\text { Histopatológico: Coloraçōes H.E., } \\
\text { Tricrômico de Masson }\end{array}$ & $\begin{array}{l}\text { Figado: Hepatite, necrótica, multifocal, moderada associada a fibrose, moderada. } \\
\text { Tricrômico de Masson confirmou fibrose hepática periportal. } \\
\text { Baç: Esplenite, aguda, moderada. Linfocitólise moderada. } \\
\text { lintestino: Enterite, crônica, linfoplasmocitária, difusa, moderada a severa, com } \\
\text { compremetimento das vilosidades e criptas, infiltrado mononuclear na lâmina própria. }\end{array}$ & Digestivo, enterite & Encontrado morto durante monitoramento de praia. \\
\hline 82 & $\begin{array}{l}\text { Arctocephalus australis } \\
\text { Macho, jovem } \\
\text { CT: } 90 \mathrm{~cm} \\
\text { Peso: } 10 \mathrm{~kg}\end{array}$ & Histopatológico: Coloração H.E. & $\begin{array}{l}\text { Pulmão: Broncopneumonia, aguda, multifocal, moderada. } \\
\text { Pneumonia, intersticial, aguda, multifocal, moderada. } \\
\text { Pneumonia, parasitária, Metastrongilidae. }\end{array}$ & $\begin{array}{l}\text { Respiratóóio, pneumonia, parasitária, } \\
\text { Metastrongilidae. }\end{array}$ & $\begin{array}{l}\text { Foi resgatado pela prefeitura local sendo amar- } \\
\text { rado pelo pescoço para encaminhamento ao } \\
\text { centro de reabilitação. Óbito no dia de ingresso. }\end{array}$ \\
\hline 83 & $\begin{array}{l}\text { Arctocephalus australis } \\
\text { Fêmea, filhote } \\
\text { Peso: } 7,8 \mathrm{~kg}\end{array}$ & Histopatológico: Coloração H.E. & 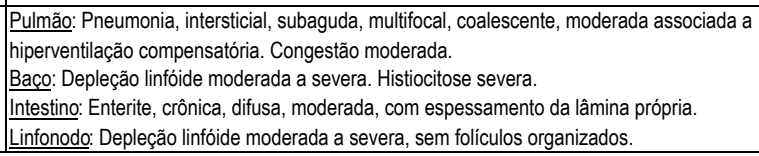 & Respiratório, pneumonia, intersticial. & $\begin{array}{l}\text { Secreção nasal catarral, submetido à antibiotico- } \\
\text { terapia, hidratação subcutânea, nebulização e } \\
\text { alimentação forçada através de sonda gástrica. } \\
\text { Óbito em centro de reabilitação } 36 \text { horas após } \\
\text { o ingresso, com temperatura retal de } 42^{\circ} \mathrm{C} \text {. }\end{array}$ \\
\hline
\end{tabular}


Cont. Tabela 4

\begin{tabular}{|c|c|c|c|c|c|}
\hline \multirow{2}{*}{ Caso No. } & \multirow{2}{*}{$\begin{array}{l}{ }^{*} \text { Caracteres } \\
\text { individuais }\end{array}$} & \multirow{2}{*}{\multicolumn{2}{|c|}{ Diagnósticos morfológicos principais }} & & \multirow[b]{2}{*}{ Comentários } \\
\hline & & & & Causa de morte & \\
\hline 84 & $\begin{array}{l}\text { Arctocephalus australis } \\
\text { Fêmea, filhote } \\
\text { CT: } 77 \mathrm{~cm} \\
\text { Peso: } 5 \mathrm{~kg}\end{array}$ & Histopatológico: Coloração H.E. & $\begin{array}{l}\text { Essôfago: Esofagite, bacteriana, multifocal, moderada. } \\
\text { Pulmäo: Atelectasia neonatal. Congestäo moderada. } \\
\text { Figado: Degeneração macro e microgoticular moderadas. Hiperceluluaridade. } \\
\text { Baço: Centros germinativos exuberantes. Linfocitólise centro-folicular moderada. }\end{array}$ & IMetabólico, hipotermia, suspeita. & $\begin{array}{l}\text { Óbito em centro de reabilitação nas primeiras } \\
\text { horas após o ingresso. }\end{array}$ \\
\hline 89 & $\begin{array}{l}\text { Arctocephalus australis } \\
\text { Macho, jovem } \\
\text { CT: } 89 \mathrm{~cm}\end{array}$ & Histopatológico: Coloração H.E. & $\begin{array}{l}\text { Pulmäo: Pneumonia, intersticial, subaguda, moderada. Predominância de células } \\
\text { mononucleares. Congestäo moderada. } \\
\text { Baç: Depleção linfóide moderada. Rarefacão centro-folicular moderada. } \\
\text { Linfonodo: Depleção linfóide severa. Rarefaçăo centro-folicular moderada. }\end{array}$ & Respiratório, pneumonia, intersticial. & Óbito em centro de reabilitação. \\
\hline 96 & $\begin{array}{l}\text { Arctocephalus australis } \\
\text { Macho, jovem } \\
\text { CT: } 88,5 \mathrm{~cm} \\
\text { Peso: } 9,5 \mathrm{~kg} \\
\end{array}$ & Histopatológico: Coloração H.E. & Autólise & Indeterminado, autólise. & Encontrado morto durante monitoramento de praia. \\
\hline 97 & $\begin{array}{l}\text { Arctocephalus australis } \\
\text { Fêmea, jovem } \\
\text { CT: } 87 \mathrm{~cm} \\
\text { Peso: } 8,5 \mathrm{~kg}\end{array}$ & Histopatológico: Coloração H.E. & Pulmão: Broncopneumonia mista, moderada. & Respiratório, broncopneumonia. & Encontrado morto durante monitoramento de praia. \\
\hline 99 & $\begin{array}{l}\text { Arctocephalus tropicalis } \\
\text { Fêmea, adulta } \\
\text { CT: } 132 \mathrm{~cm} \\
\text { Peso: } 39 \mathrm{~kg}\end{array}$ & Histopatológico: Coloração H.E. & $\begin{array}{l}\text { Pulmão: Extensas áreas de congestão e hemorragia severas. } \\
\text { Figado: Edema celular moderado a severo. Congestão centrolobular moderada. } \\
\text { Baço: Hipoplasia linfoide severa. Linfocitólise multisetorial severa. }\end{array}$ & Metabólico, estresse. & $\begin{array}{l}\text { Reabilitado em zoológico. } \\
\text { Na noite anterior à liberação foi colocado em } \\
\text { caixa de transporte. Noite de calor extremo. } \\
\text { Encontrado morto no dia seguinte. }\end{array}$ \\
\hline 100 & $\begin{array}{l}\text { Arctocephalus tropicalis } \\
\text { Macho, adulto } \\
\text { CT: } 172 \mathrm{~cm} \\
\text { Peso: } 90 \mathrm{~kg}\end{array}$ & Histopatológico: Coloração H.E. & 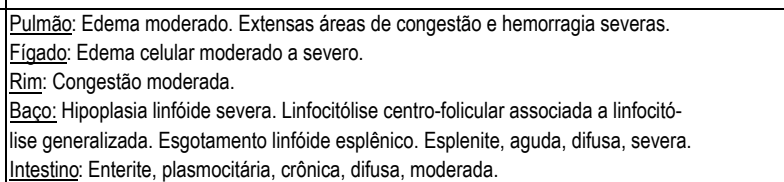 & Metabólico, estresse. & $\begin{array}{l}\text { Reabilitado em zoológico. } \\
\text { Na noite anterior à liberação foi colocado em } \\
\text { caixa de transporte. Noite de calor extremo. } \\
\text { Encontrado morto no dia seguinte. }\end{array}$ \\
\hline 103 & $\begin{array}{l}\text { Arctocephalus australis } \\
\text { Fêmea, jovem } \\
\text { CT: } 91 \mathrm{~cm} \\
\text { Peso: } 9 \mathrm{~kg}\end{array}$ & Histopatológico: Coloração H.E. & Baço: Hipoplasia linfóide severa. & Metabólico, estresse, suspeita. & Encontrado morto durante monitoramento de praia. \\
\hline 104 & $\begin{array}{l}\text { Arctocephalus australis } \\
\text { Macho, jovem } \\
\text { CT: } 90 \mathrm{~cm} \\
\text { Peso: } 12 \mathrm{~kg}\end{array}$ & $\begin{array}{l}\text { Histopatológico: Colorações H.E., } \\
\text { Gram, PAS e Perlls. }\end{array}$ & $\begin{array}{l}\text { Pulmão: Congestão moderada. Pneumonia, lobar, severa. Pneumonia, intersticial, } \\
\text { aguda, difusa, moderada. Hemorragia, coalescente, multifocal, moderada. } \\
\text { Baço: Depleção linfóide severa. }\end{array}$ & Respiratório, pneumonia, lobar. & $\begin{array}{l}\text { Encontrado morto durante monitoramento de praia. } \\
\text { As coloraçōes especificas não contribuiram } \\
\text { para elucidação do processo. }\end{array}$ \\
\hline 107 & $\begin{array}{l}\text { Arctocephalus tropicalis } \\
\text { Macho, adulto } \\
\text { CT: } 164,5 \mathrm{~cm} \\
\text { Peso: } 60 \mathrm{~kg}\end{array}$ & $\begin{array}{l}\text { Histopatológico: Colorações H.E., } \\
\text { Vermelho Congo e Tricrômico de } \\
\text { Masson. } \\
\text { Parasitológico } \\
\text { Bacteriológico }\end{array}$ & 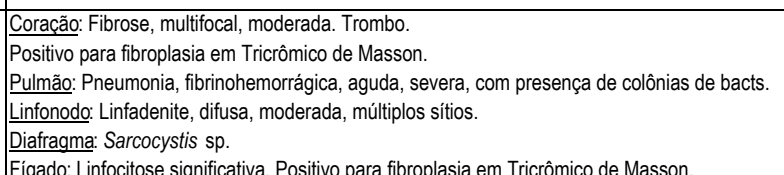 & $\begin{array}{l}\text { Respiratório, pneumonia, bacteriana, } \\
\text { Morganella morganii. }\end{array}$ & $\begin{array}{l}\text { Encontrado morto e encaminhado a instituição } \\
\text { de ensino. }\end{array}$ \\
\hline 108 & $\begin{array}{l}\text { Otaria flavescens } \\
\text { Macho, neonato } \\
\text { Peso: } 13,1 \mathrm{~kg}\end{array}$ & Histopatológico: Coloração H.E. & $\begin{array}{l}\text { Pulmão: Áreas atelectásicas. Presença de liquido e C.E. por todo o parênquima. } \\
\text { Figado: Degeneraçâo macro e microgoticular severa. }\end{array}$ & Perinatal, respiratório, asfixia. & $\begin{array}{l}\text { Parto distócico, havendo estragulamento do filhote } \\
\text { no canal vaginal. }\end{array}$ \\
\hline 109 & $\begin{array}{l}\text { Otaria flavescens } \\
\text { Macho, jovem } \\
\text { CT: } 181 \mathrm{~cm} \\
\text { Peso: } 150 \mathrm{~kg}\end{array}$ & Histopatológico: Coloração H.E. & $\begin{array}{l}\text { Pulmão: Congestão e edema, moderados. Derrame fibrinoso. Pneumonia, intersticialal, } \\
\text { crônica, difusa, moderada. Hemorragia, coalescente, multifocal, severa. } \\
\text { Baço: Hipoplasia linfóide severa. } \\
\text { Figado: Congestão severa. } \\
\text { Intestino delgada: Enterite, crônica, difusa, moderada. }\end{array}$ & Respiratório, pneumonia, intersticial. & Encalhe. \\
\hline 110 & $\begin{array}{l}\text { Otaria flavescens } \\
\text { Macho, jovem } \\
\text { CT: } 131 \mathrm{~cm} \\
\text { Peso: } 25 \mathrm{~kg}\end{array}$ & Histopatológico: Coloração H.E. & $\begin{array}{l}\text { Pulmäo: Parasitas no parênquima e espaço alveolar. Pneumonia, parasitária, fibrinosa, mode- } \\
\text { rada a severa, associada a extensas áreas de edema, hemorragia e congestão moderadas. } \\
\text { Baço: Hipoplasia linfóide severa. }\end{array}$ & Respiratório, pneumonia, parasitária. & Encalhe. \\
\hline
\end{tabular}


Cont. Tabela 4

Legenda:

${ }^{*}$ Foram relatadas as informacōes disponibilizadas pelos coletores.

Nomes cientificos e nomes comuns dos animais apresentados:

Arctocephalus australis: lobo-marinho-do-sul

Arctocephalus tropicalis: lobo-marinho-subantártico

Eumetopias jubatus: leâo-marinho-de-Steller

Leptonychotes weddellii: foca-de-Weddell

Otaria flavescens: leâa-marinho-do-sul 
Tabela 7. Distribuição dos resultados de exames microbiológicos realizados em cetáceos e pinípedes necropsiados junto ao LAPCOM e por terceiros, em função do Caso No. Sudeste do Brasil, 1997-2002

\begin{tabular}{|c|c|c|c|c|}
\hline Caso No. & $\begin{array}{l}\text { - SANGUE - } \\
\text { bacteriano }\end{array}$ & $\begin{array}{c}\text { - OUTROS - } \\
\text { bacteriano }\end{array}$ & $\begin{array}{l}\text { - SANGUE - } \\
\text { fungo/levedura }\end{array}$ & $\begin{array}{c}\text { - OUTROS - } \\
\text { fungo/levedura }\end{array}$ \\
\hline *18 & Organismo não fermentador de glicose & Linfonodo axilar: Negativo & N.R. & N.R. \\
\hline 34 & Negativo & $\begin{array}{l}\text { Pulmão, intestino e útero: } \\
\text { Negativo }\end{array}$ & Negativo & Negativo \\
\hline 38 & $\begin{array}{l}\text { Col. 1- Staphylococcus xylosus } \\
\text { Col. 2- Gemella haemolisans }\end{array}$ & $\begin{array}{l}\text { Swab abscesso pulmonar: } \\
\text { Staphylococcus sp. } \\
\text { Fígado, pulmão, rim e fluido } \\
\text { pericárdico: Negativo }\end{array}$ & Negativo & N.R. \\
\hline *39 & $\begin{array}{l}\text { Escherichia coli } \\
\text { Staphylococcus sp. }\end{array}$ & Pulmão: Proteus sp. & N.R. & N.R. \\
\hline *41 & N.R. & $\begin{array}{l}\text { Pulmão: Escherichia coli } \\
\text { Klebsiella pneumoniae }\end{array}$ & N.R. & N.R. \\
\hline 43 & Negativo & N.R. & N.R. & N.R. \\
\hline 46 & Negativo & N.R. & Negativo & N.R. \\
\hline 47 & Negativo & N.R. & Negativo & N.R. \\
\hline 48 & $\begin{array}{l}\text { Col. 1- Pasteurella pneumotropica } \\
\text { Col. 2- Pseudomonas aeruginosa } \\
\text { Líquido cavidade torácica: } \\
\text { Pseudomonas aeruginosa }\end{array}$ & $\begin{array}{c}\text { Swab orifício respiratório: } \\
\text { Staphylococcus sciuri } \\
\text { Pseudomonas aeruginosa } \\
\text { Swab pulmão: Pseudomonas sp. } \\
\text { Swab fígado: } \\
\text { Pseudomonas aeruginosa } \\
\text { Swab duodeno: Não identificado }\end{array}$ & N.R. & N.R. \\
\hline 49 & Não identificado & N.R. & Negativo & N.R. \\
\hline
\end{tabular}




\begin{tabular}{|c|c|c|c|c|}
\hline $\mathrm{N}^{\circ}$ de RPC & $\begin{array}{l}\text { - SANGUE - } \\
\text { bacteriano }\end{array}$ & $\begin{array}{l}\text { - OUTROS - } \\
\text { bacteriano }\end{array}$ & $\begin{array}{c}\text { - SANGUE - } \\
\text { fungo/levedura }\end{array}$ & $\begin{array}{l}\text { - OUTROS - } \\
\text { fungo/levedura }\end{array}$ \\
\hline 98 & Negativo & $\begin{array}{l}\text { Swab cavidade torácica: Negativo } \\
\text { Líquido cavidade torácica: } \\
\text { Micrococcus sp. } \\
\text { Pulmão: } \\
\text { Col. 1- Staphylococcus sp. } \\
\text { Col. 2- Staphylococcus sp. } \\
\text { Col. 3- Staphylococcus sp. }\end{array}$ & Negativo & Negativo \\
\hline 107 & N.R. & Pulmão: Morganella morganii & N.R. & Negativo \\
\hline
\end{tabular}

* Amostras processadas na origem.

N.R.: Não realizado/ não reportado. 
Tabela 9. Distribuição dos resultados parasitológicos observados em órgãos de cetáceos e pinípede analisados pela pós-graduanda Juliana Marigo, em função do Caso No. e da espécie animal. Sudeste do Brasil, 1997 - 2002

\begin{tabular}{|c|c|c|l|}
\hline Caso No. & Espécie & CT Int (m) & \multicolumn{1}{c|}{ Órgãos/Parasitos encontrados } \\
\hline \hline 3 & Sotalia fluviatilis & 7,75 & Intestino: 10 Hadwenius tursionis; Pulmão: não analisado; Estômago: zero \\
\hline 4 & Pontoporia blainvillei & N.R. & Intestino: não analisado; Pulmão: zero; Estômago: zero \\
\hline 5 & Pontoporia blainvillei & 26,5 & Intestino: 84 Hadwenius pontoporiae; Pulmão: zero; Estômago: zero \\
\hline 19 & Pontoporia blainvillei & 22,2 & Intestino: 21 Hadwenius pontoporiae; Pulmão: não analisado; Estômago: zero \\
\hline 20 & Pontoporia blainvillei & 32,3 & Intestino: zero; Pulmão: não analisado; Estômago: zero \\
\hline 34 & Pontoporia blainvillei & 34,15 & Intestino: 28 Hadwenius pontoporiae; Pulmão: não analisado; Estômago: não analisado \\
\hline 38 & Steno bredanensis & 13,2 & Intestino: 161 trematóides + 6 acantocéfalos + 1 nematóide; Pulmão: zero; \\
& & Estômago: 30 Braunina cordiformis + 20 acantocéfalos + 8 nematóides \\
\hline 43 & Sotalia fluviatilis & 9 & Intestino: 6 Hadwenius tursionis; Pulmão: D 25 / E 25 Halocercus brasiliensis; Estômago: não analisado \\
\hline 46 & Stenella frontalis & 16,2 & Intestino: 47 acantocéfalos + 6 cestóides + 1 nematóides; Pulmão: zero; Estômago: não analisado \\
\hline 47 & Stenella frontalis & 16,7 & Intestino: 54 acantocéfalos + 5 cestóides; Pulmão: zero; Estômago: não analisado \\
\hline 49 & Pontoporia blainvillei & 29,1 & Intestino: 17 Hadwenius pontoporiae , Pulmão: zero; Estômago: não analisado \\
\hline 51 & Sotalia fluviatilis & 10,8 & Intestino: 11 Hadwenius tursionis; Pulmão: E 50 Halocercus brasiliensis; Estômago:1 Bolbossoma sp \\
\hline 52 & Pontoporia blainvillei & 27,92 & Intestino:13 Hadwenius pontoporiae; Pulmão: não analisado; Estômago: zero \\
\hline 53 & Pontoporia blainvillei & N.R. & Intestino: 11 Hadwenius pontoporiae; Pulmão: não analisado; Estômago: zero \\
\hline 54 & Pontoporia blainvillei & 18,45 & Intestino: zero; Pulmão: não analisado; Estômago: zero \\
\hline 98 & Pontoporia blainvillei & 23,2 & Intestino: 9 Hadwenius pontoporiae; Pulmão: zero; Estômago: não analisado \\
\hline 107 & Artocephalus tropicalis & N.R. & Intestino: 12 nematóides + 242 acantocéfalos; Estômago: 136 nematóides \\
\hline
\end{tabular}

Legenda:

CT Int: Comprimento total do intestino

D: Direito

E: Esquerdo

N.R.: Não realizado

\section{Nomes científicos e nomes comuns apresentados:}

Cetáceos:

Pontoporia blainvillei: franciscana ou toninha

Sotalia fluviatilis: boto cinza ou tucuxi

Stenella frontalis: golfinho-pintado-do-atlântico

Steno bredanensis: golfinho-de-dentes-rugosos

Pinípede:

Arctocephalus tropicalis: lobo-marinho-subantártico 
Figura 1. Animal disposto para a necróspia no VPT. Stenella frontalis - Caso No. 46

Figura 2. Lesões cortantes provocadas pelo enrredamento. Stenella frontalis - Caso No. 47

Figura 3. Animal disposto para a necróspia no VPT. Observar as marcas de rede no rostro, cabeça, e cicatriz no centro do melão. Observa-se ainda opacidade no cristalino. Pontoporia blainvillei - Caso No. 98

Figura 4. Pulmão de aspecto marmorizado, apresentando enfisema, edema e congestão. Pneumonia aspirativa. Arctocephalus tropicalis - Caso No. 107

Figura 5. Cistos ovarianos. Pontoporia blainvillei - Caso No. 34 


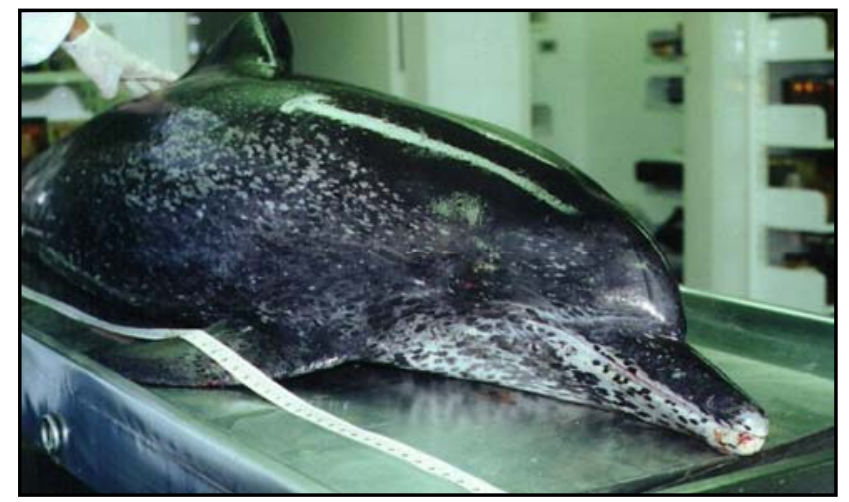

Figura 1

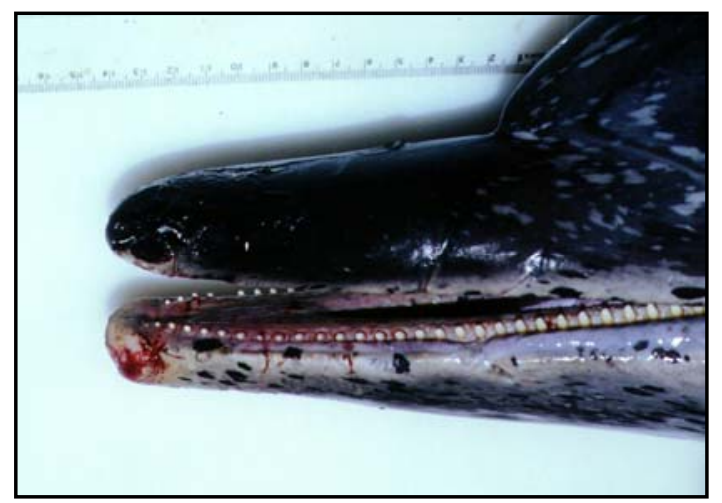

Figura 2

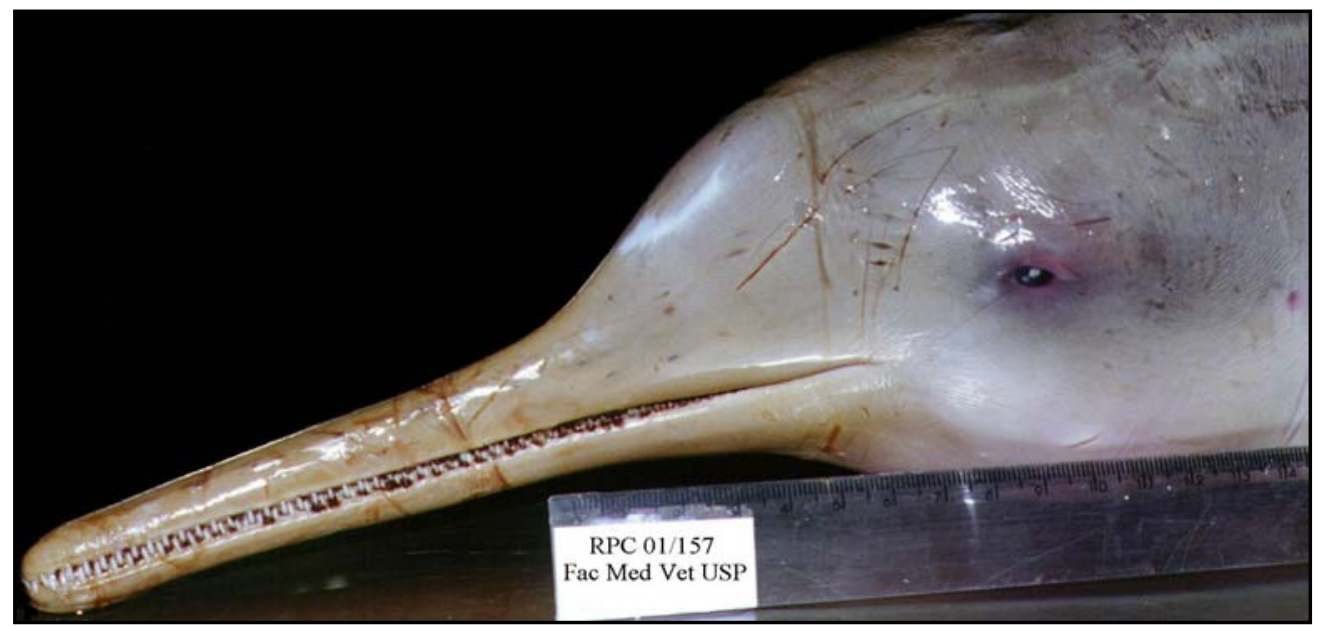

Figura 3
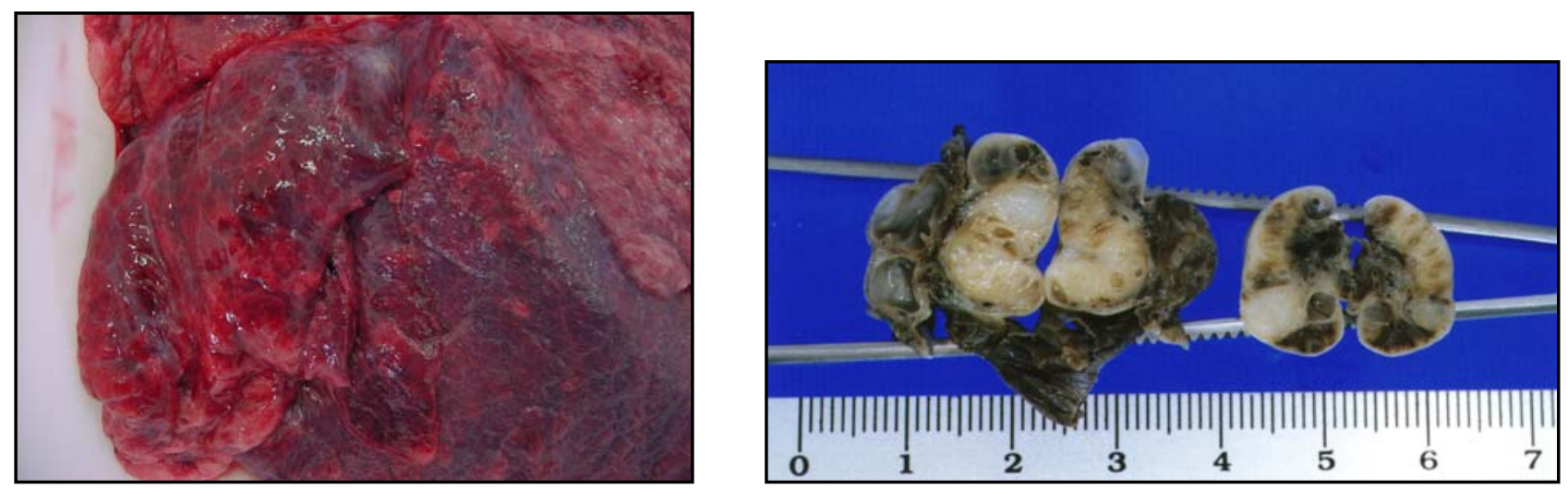

Figura 4

Figura 5 
Figura 6. Nefromegalia de aspecto nodular cístico in situ. Nota-se ainda a glândula supra-renal, o baço e baços acessórios. Steno bredanensis - Caso No. 38

Figura 7. Detalhe do rim policístico. Observar a pouca quantidade de parênquima funcional. Steno bredanensis - Caso No. 38

Figura 8. Formações cutâneas verrucosas na comissura labial. Steno bredanensis - Caso No. 38

Figura 9. Corte histológico da formação ilustrada na Figura 8. Notar a estrutura característica de lesão papilomatosa. Steno bredanensis - Caso No. 38 (H.E., 40x)

Figura 10. Pênis, notar formações cutâneas nodulares. Material fixado em formalina 10\%. Tursiops truncatus - Caso No. 7

Figura 11. Pênis, visão microscópica das formações cutâneas ilustradas na Figura 10. Observar hiperplasia de tecido linfóide (seta). Tursiops truncatus - Caso No. 7 (H.E., 40x) 


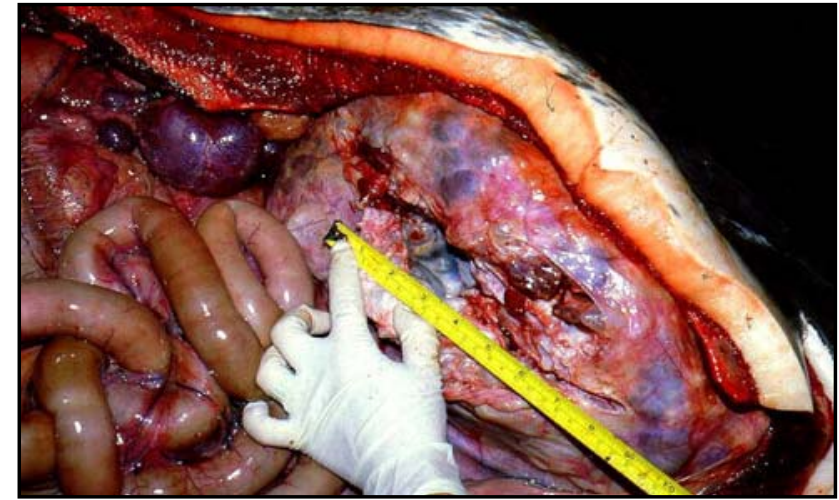

Figura 6

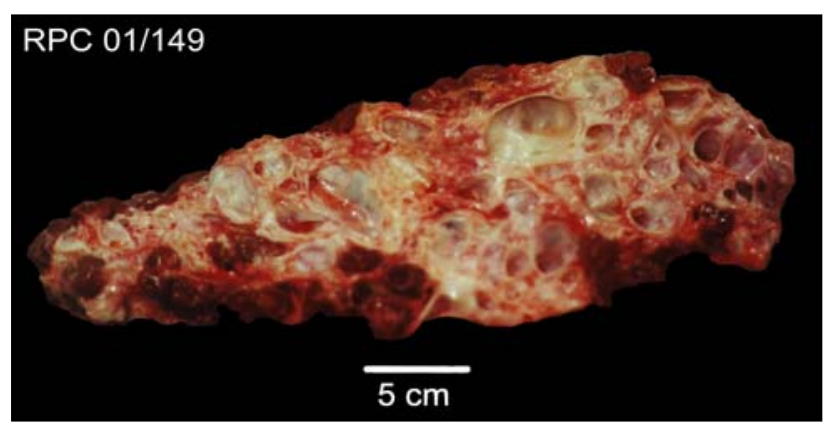

Figura 7

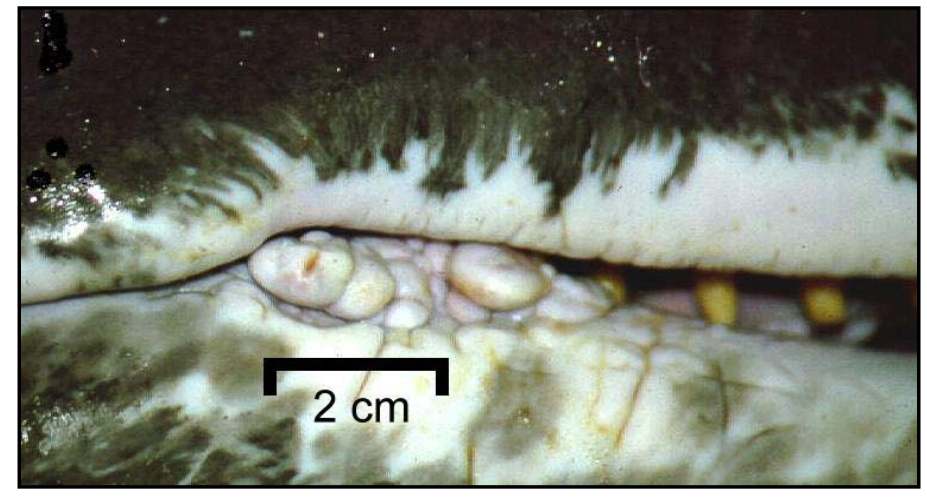

Figura 8

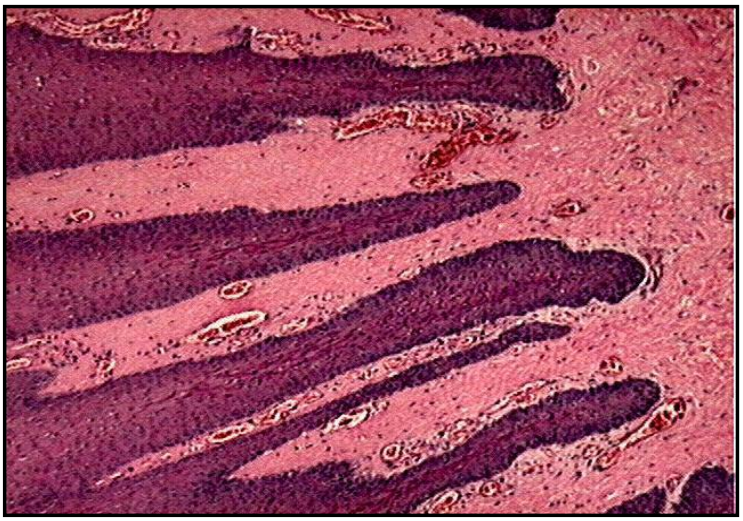

Figura 9

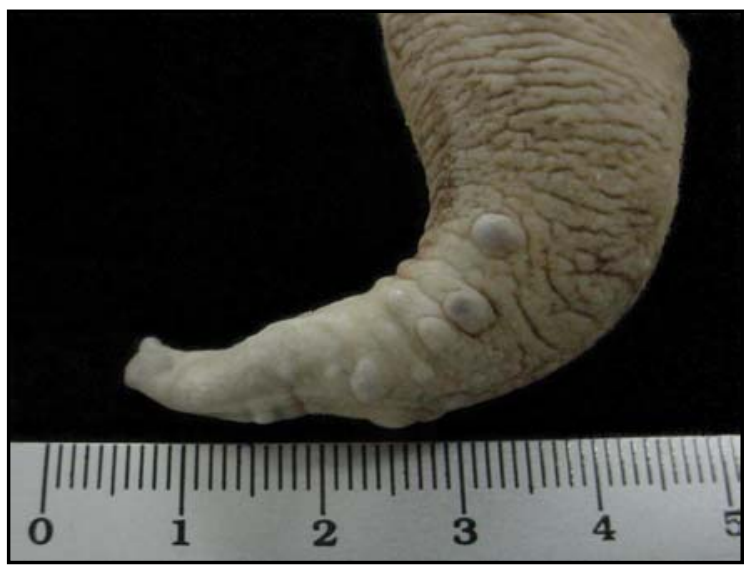

Figura 10

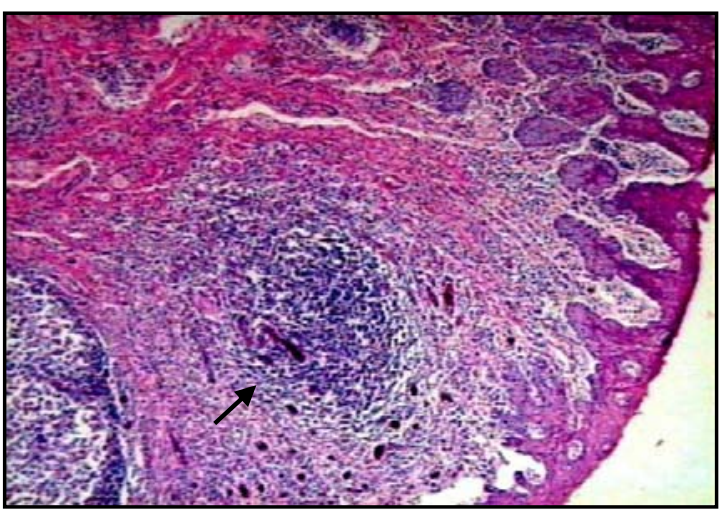

Figura 11 
Figura 12. Pulmão, abscedação. Tursiops truncatus - Caso No. 7

Figuras 13a e b. Detalhes do corte apresentado na Figura 12, notar parasita nematóide no centro do abscesso. Tursiops truncatus - Caso No. 7 (H.E., 20 e 100x)

Figura 14. Pulmão, notar alterações comumente encontradas nos casos de captura acidental: congestão (1) e edema (2). Pontoporia blainvillei - Caso No. 34 (H.E., 100x)

Figura 15. Pulmão, detalhe da Figura 14. Congestão (1) e edema (2). Pontoporia blainvillei Caso No. 34 (H.E., 200x)

Figura 16. Fígado, observar local de perfuração do objeto contundente, notar fibroplasia. Pontoporia blainvillei - Caso No. 98 (Tricrômico de Masson, 20x)

Figura 17. Fígado, detalhe da Figura 16. Pontoporia blainvillei - Caso No. 98 (Tricrômico de Masson, 40x) 


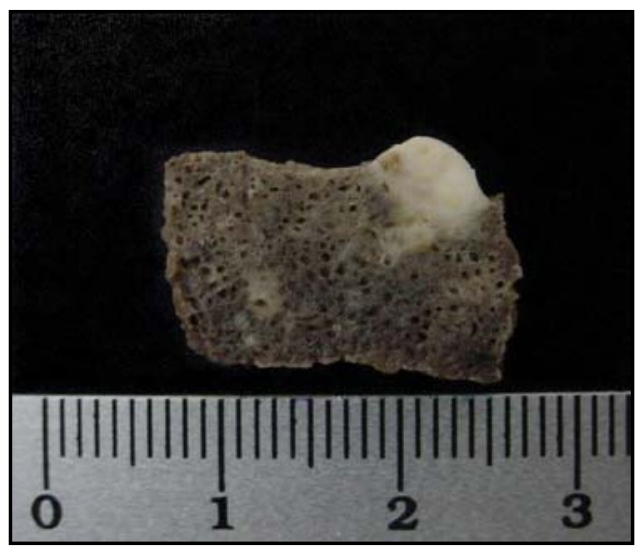

Figura 12

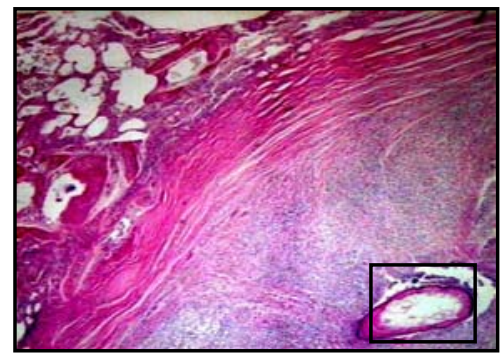

Figura 13a

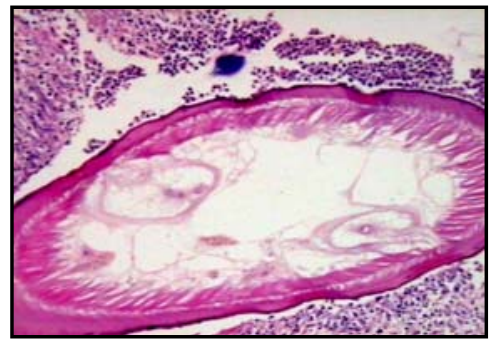

Figura 13b

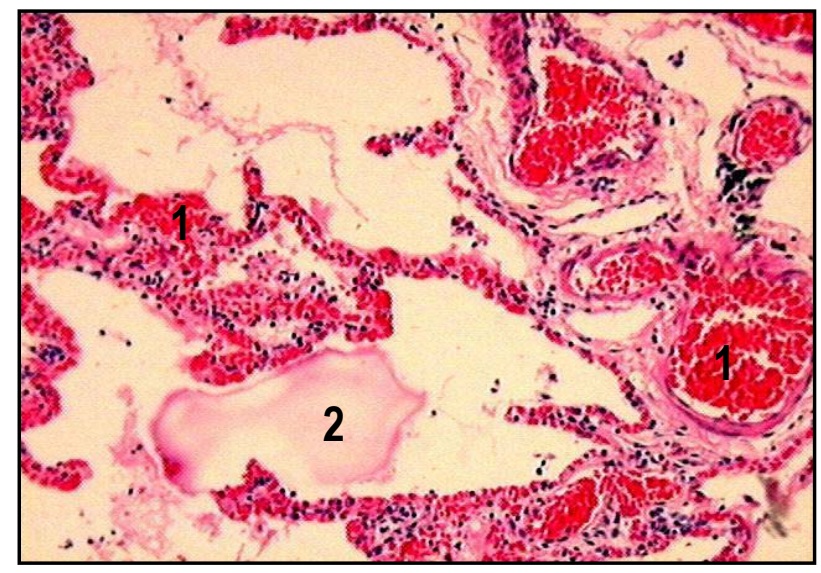

Figura 14

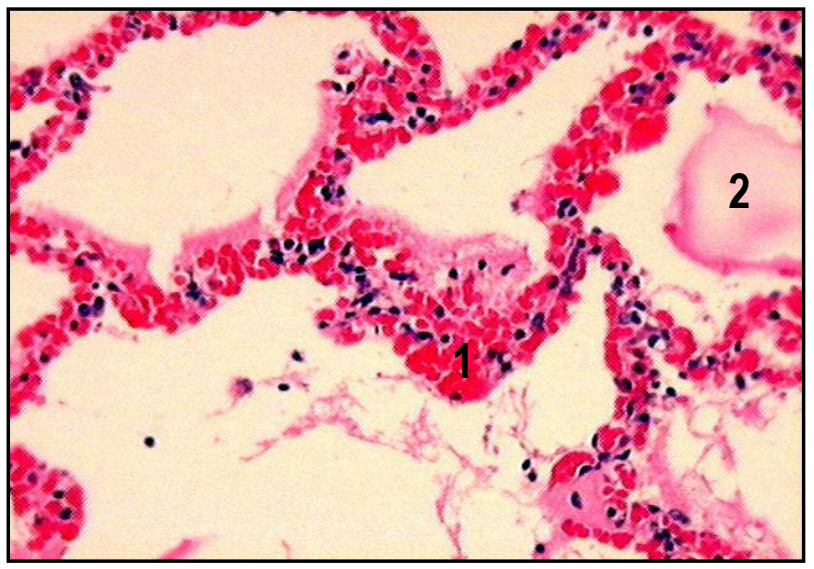

Figura 15

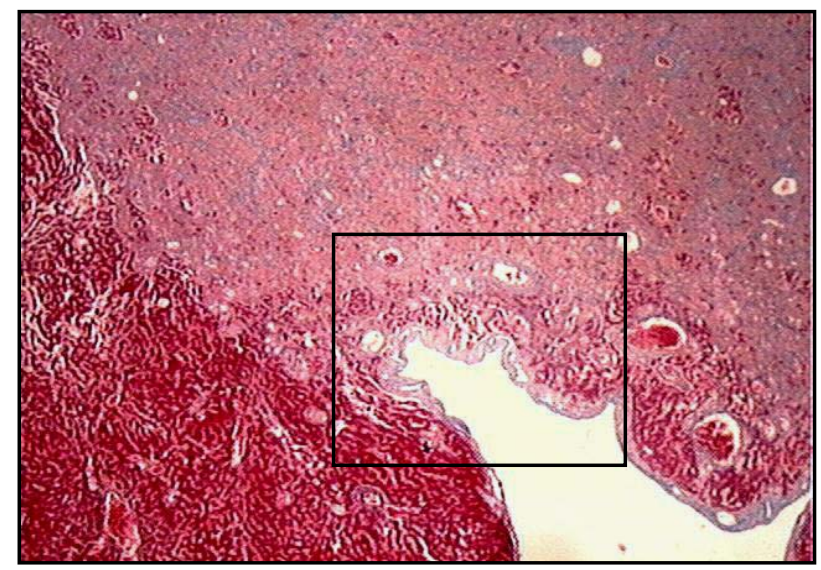

Figura 16

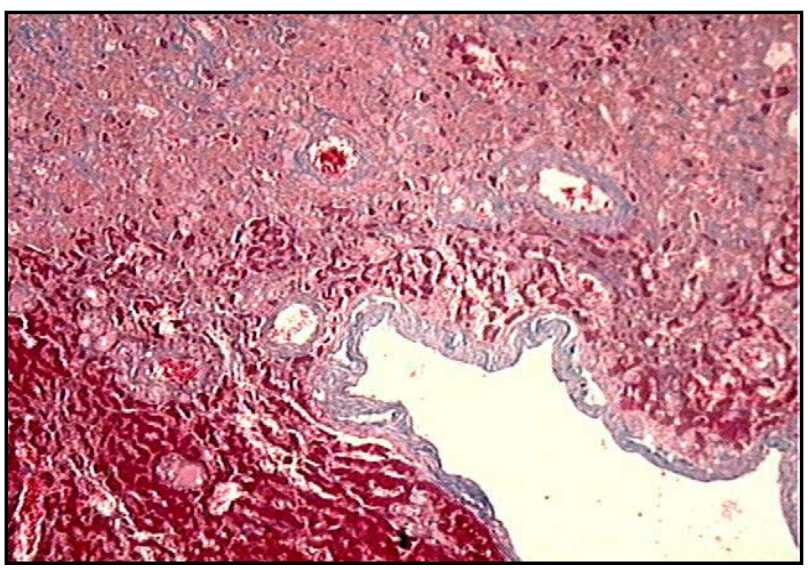

Figura 17 
Figura 18. Fígado, mesma região ilustrada nas Figuras 16 e 17, positiva para hemossiderose. Pontoporia blainvillei - Caso No. 98 (Perls, 40x)

Figura 19. Fígado, notar hiperplasia ductal exuberante. Pontoporia blainvillei Caso No. 98 (H.E., 40x)

Figura 20. Pulmão, pneumonia, intersticial, crônica, difusa, severa com calcificação distrófica (seta) e carneificação do parênquima (1). Otaria flavescens Caso No. 44 (H.E., 40x)

Figura 21. Pulmão, detalhe da Figura 20. Confirmação da fibroplasia. Otaria flavescens Caso No. 44 (Tricrômico de Masson, 100x)

Figura 22. Notar fibrose cardíaca. Arctocephalus tropicalis - Caso No. 107

Figura 23. Coração, coloração positiva para fibroplasia. Arctocephalus tropicalis Caso No. 107 (Tricrômico de Masson, 20x) 


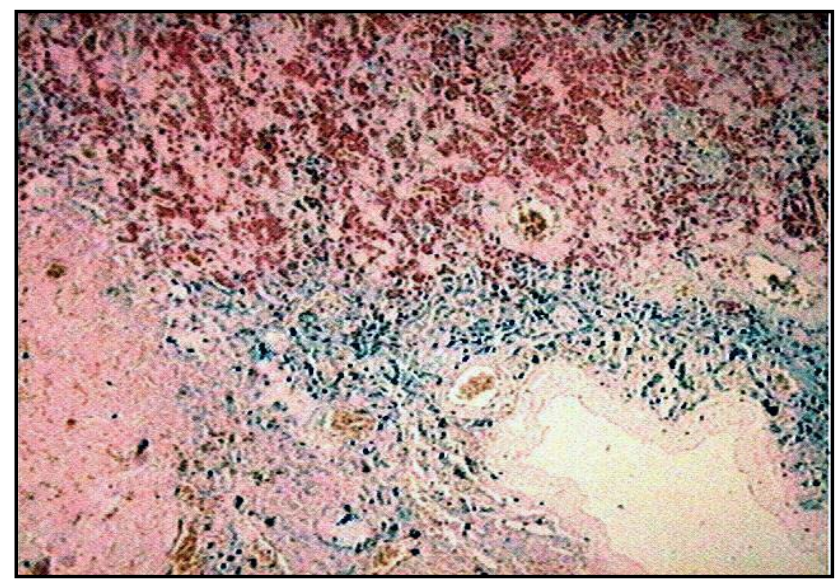

Figura 18

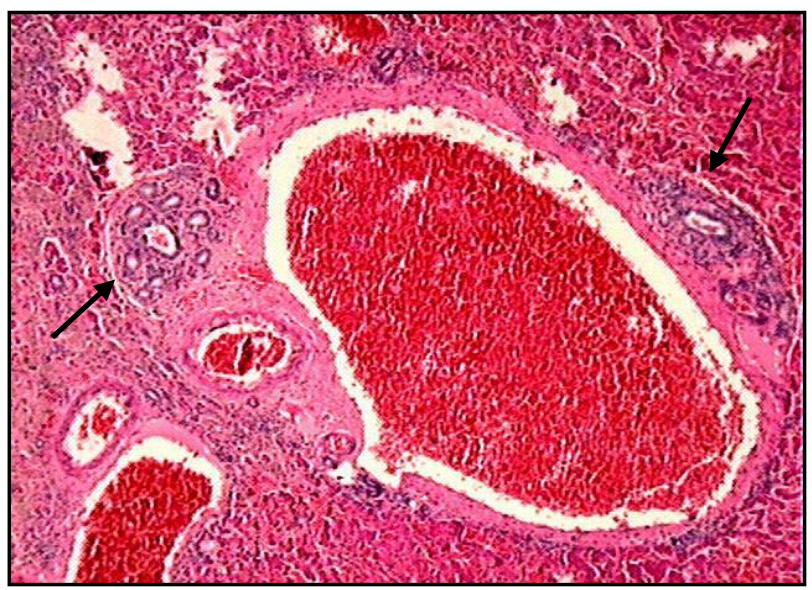

Figura 19

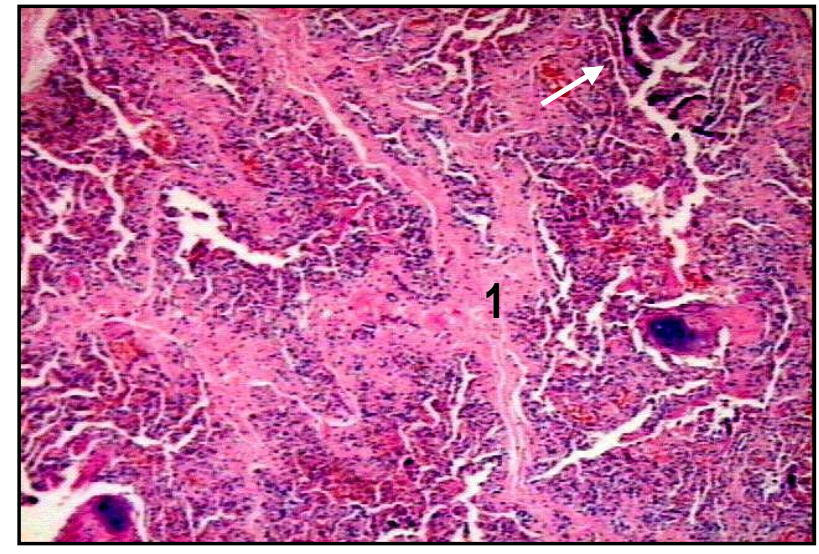

Figura 20

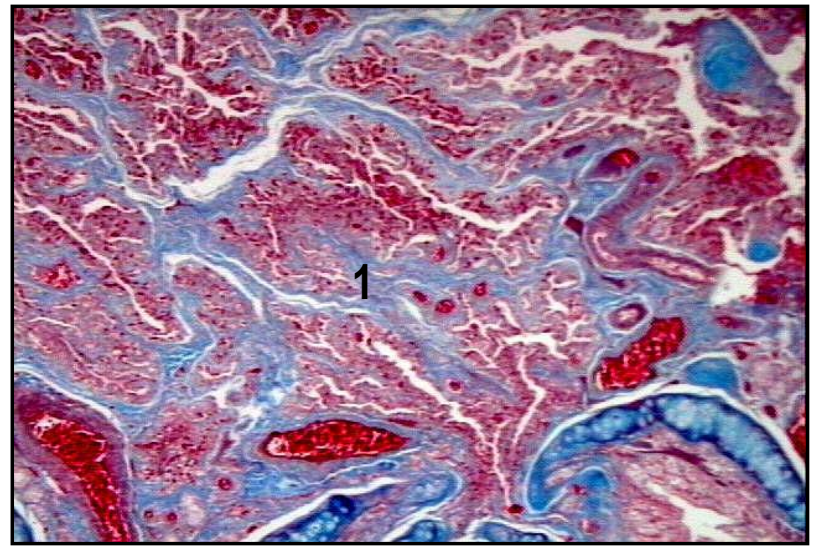

Figura 21
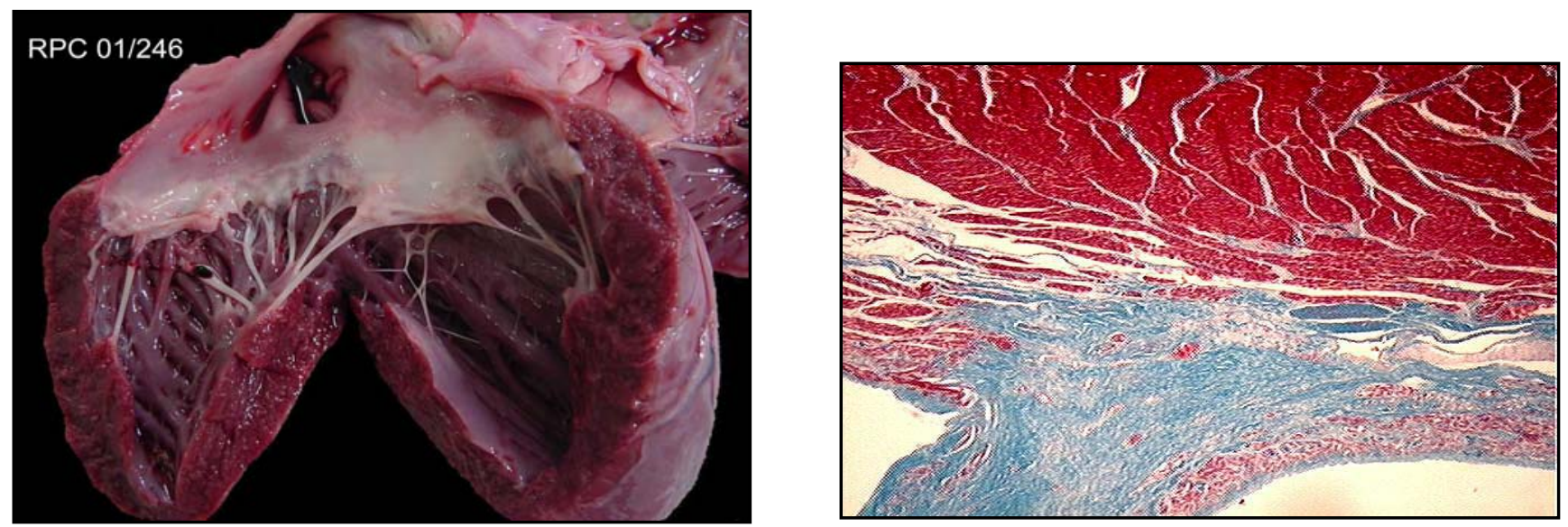
Figura 24. Pulmão, pneumonia aspirativa. Observar material particulado nos espaços aéreos (seta). Pontoporia blainvillei - Caso No. 48 (H.E., 100x)

Figura 25. Pulmão, detalhe da Figura 24. Observar material particulado nos espaços aéreos (seta). Pontoporia blainvillei - Caso No. 48 (H.E., 400x)

Figura 26. Pulmão, broncopneumonia, purulenta, difusa, moderada a severa. Notar grande quantidade de eosinófilos (seta). Sotalia fluviatilis Caso No. 43 (H.E., 100x)

Figura 27. Pulmão, notar Metastrongilidae no espaço alveolar. Sotalia fluviatilis Caso No. 8 (H.E., 40x)

Figura 28. Linfonodo, linfadenite, eosinofílica, difusa, moderada a severa. Notar recrutamento maciço de eosinófilos em direção ao pulmão (setas). Sotalia fluviatilis - Caso No. 43 (H.E., 40x)

Figura 29. Detalhe indicado na Figura 28. Linfonodo, observar grande quantidade de eosinófilos (setas). Sotalia fluviatilis - Caso No. 43 (H.E., 100x) 


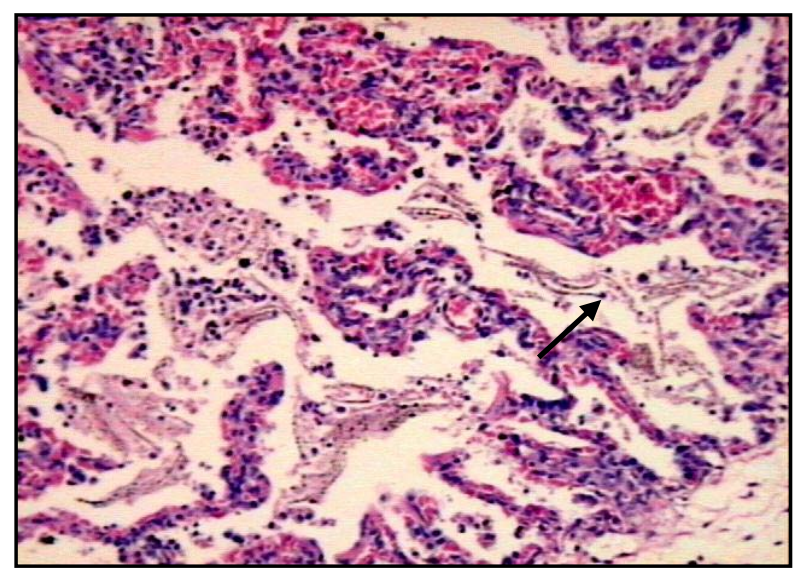

Figura 24

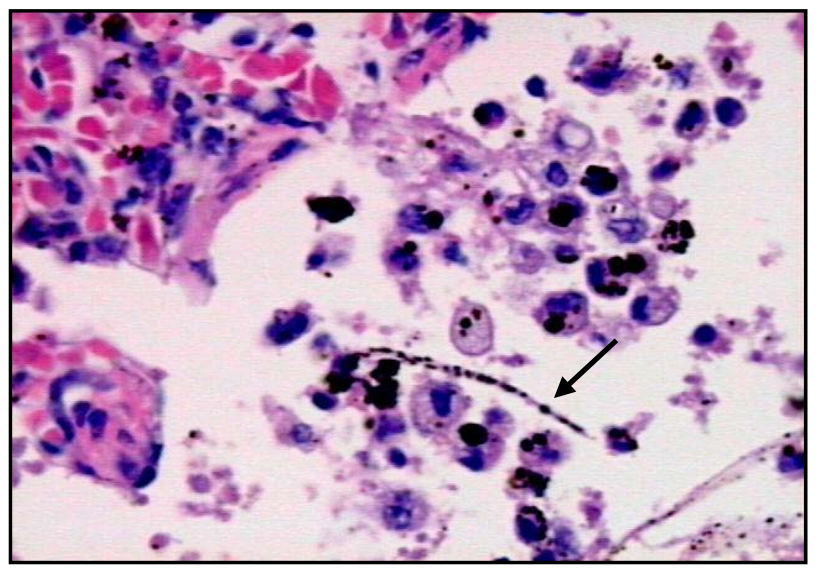

Figura 25

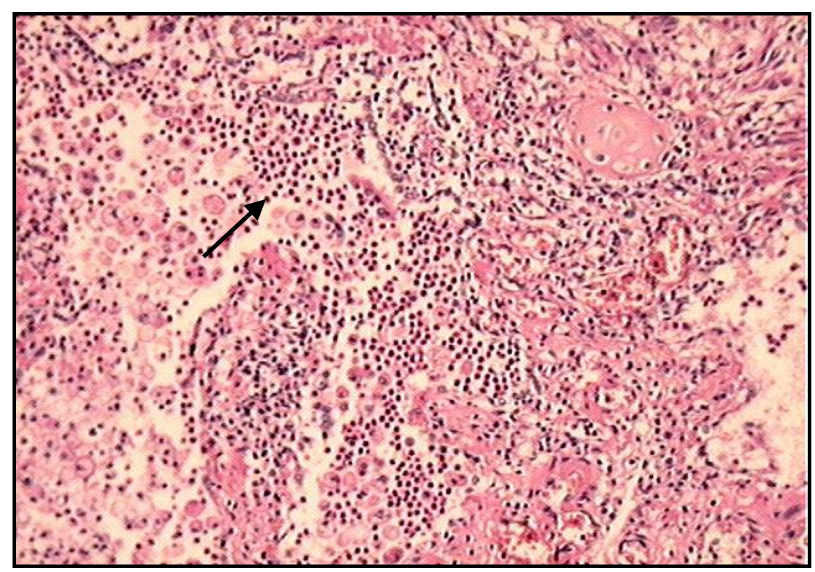

Figura 26

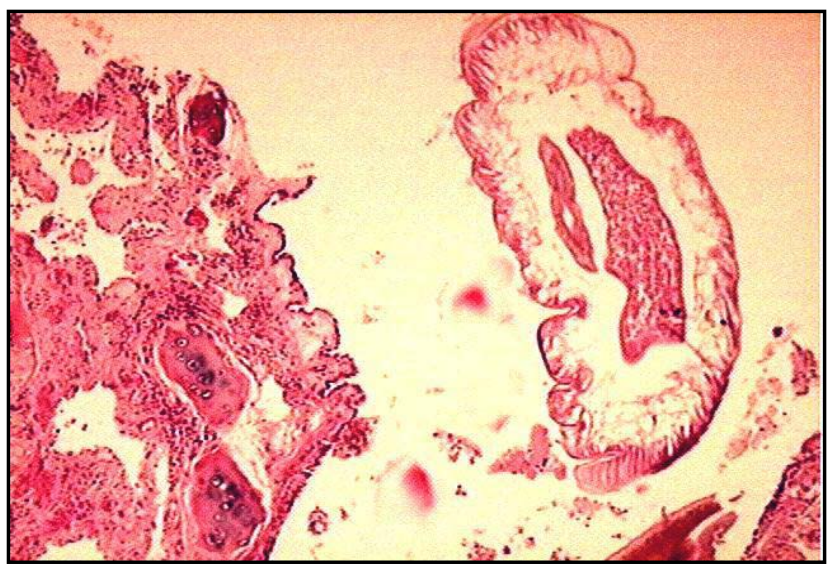

Figura 27

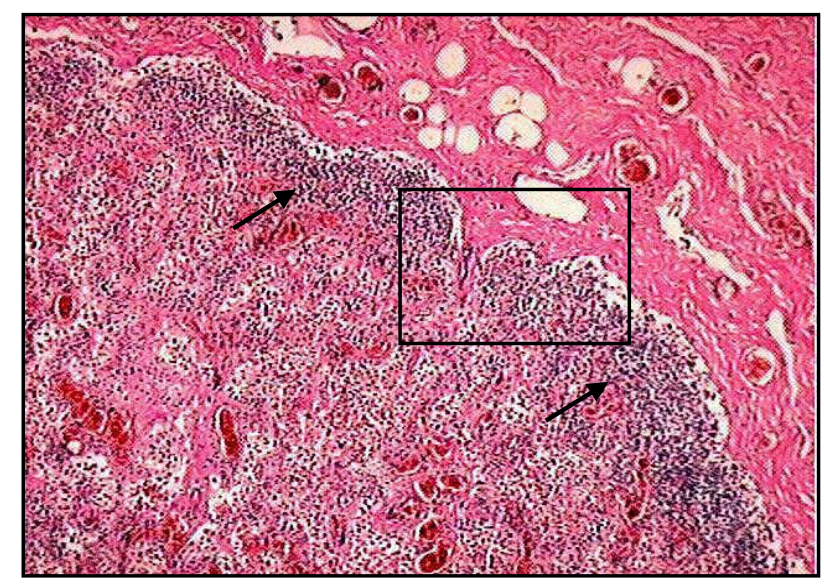

Figura 28

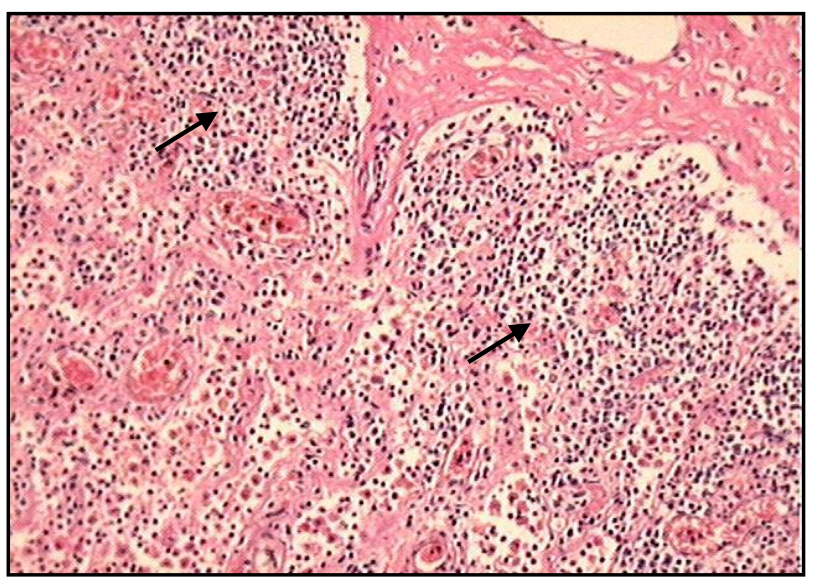

Figura 29 
Figura 30. Metastrongilidae e larvas no parênquima pulmonar. Arctocephalus australis Caso No. 82 (H.E., 40x)

Figura 31. Detalhe indicado na Figura 30. Arctocephalus australis - Caso No. 82 (H.E., 200x)

Figura 32. Pulmão, vista geral do órgão apresentando pneumonia, crônica, granulomatosa induzida por cristais de colesterol. Notar pleuropneumonia, crônica, difusa. Pontoporia blainvillei - Caso No. 98 (H.E., 20x)

Figura 33. Pulmão, pneumonia, crônica, granulomatosa induzida por cristais de colesterol. Notar formação de células gigantes (seta) Pontoporia blainvillei - Caso No. 98 (H.E., 100x)

Figuras 34a e b. Fígado, observar degeneração macro e microgoticular severa. Pontoporia blaivillei - Caso No. 90 (H.E., 100 e 200x)

Figuras 35a e b. Fígado, confirmação do acúmulo de lipídios. Pontoporia blaivillei Caso No. 90 (Sudan Black, 40 e 100x) 


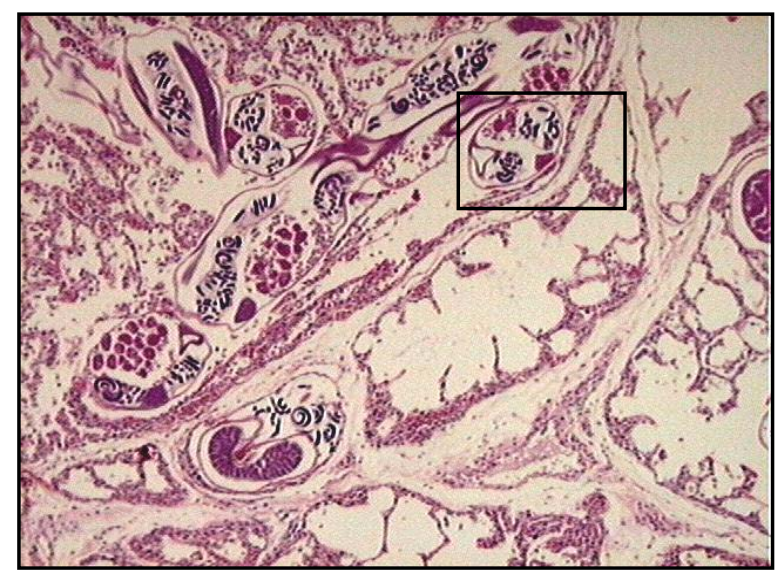

Figura 30

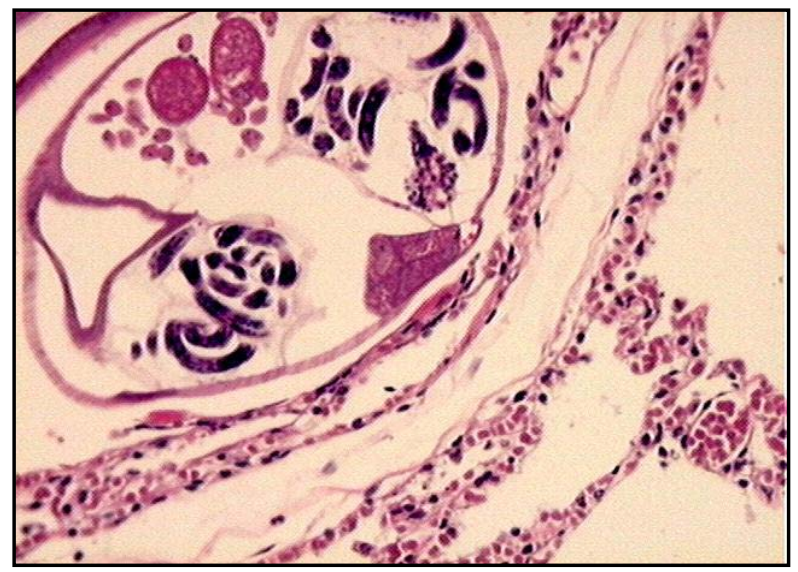

Figura 31

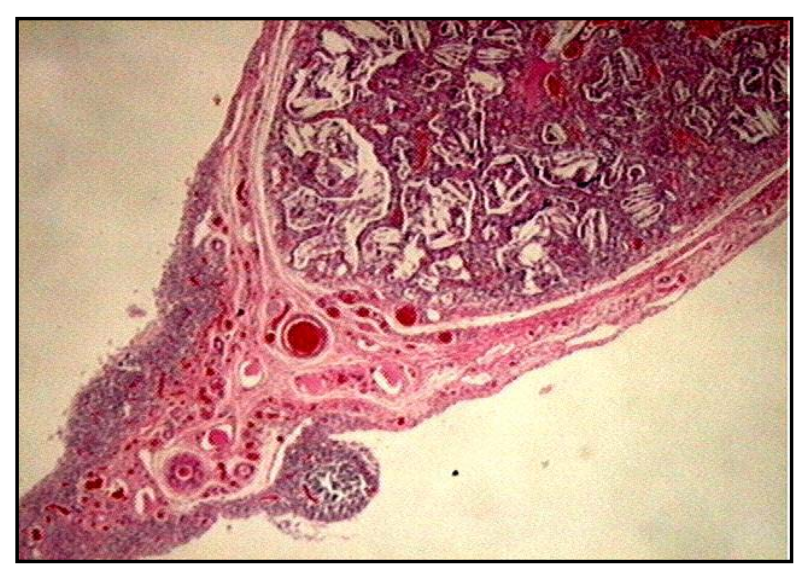

Figura 32

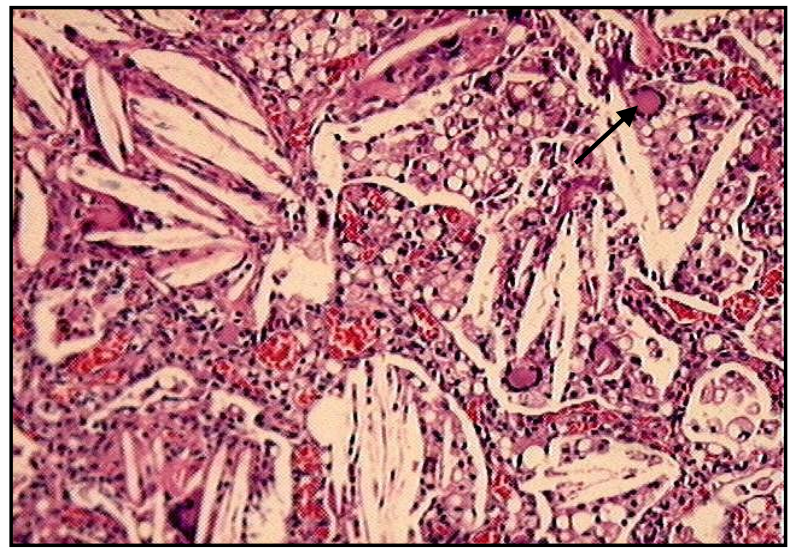

Figura 33

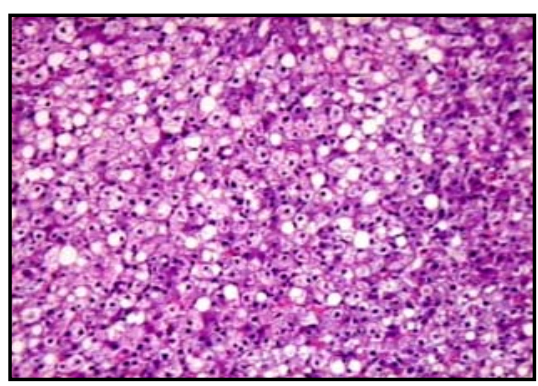

Figura 34a

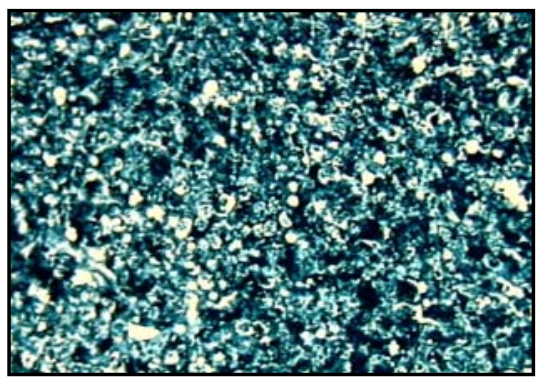

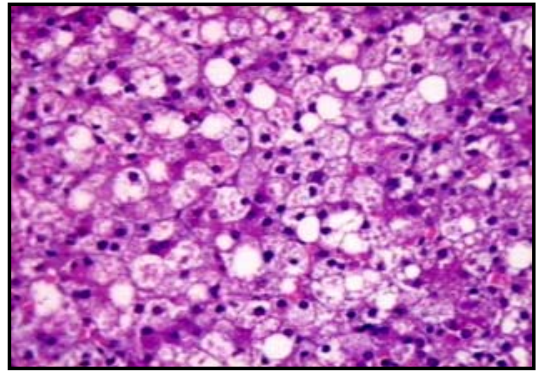

Figura 34b

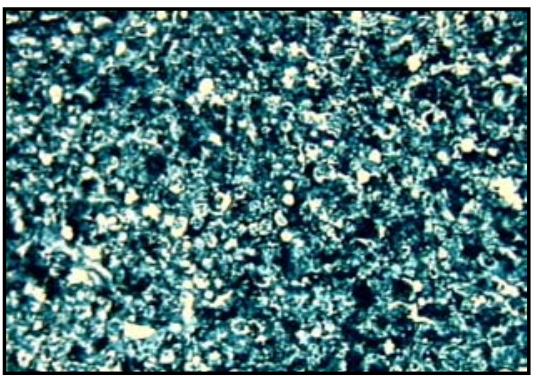

Figura 35b 
Figuras 36a e b. Rim, observar acúmulo de lipídios no túbulos contorcidos proximais. Stenella longirostris - Caso No. 27 (H.E., 40 e 400x)

Figuras 37a e b. Rim, confirmação do acúmulo de lipídios. Stenella longirostris - Caso No. 27 (Sudan Black, 40 e 200x)

Figura 38. Baço, esplenite, parasitária. Notar ovos de parasitas trematóides (setas) e a formação de células gigantes. Steno bredanensis - Caso No. 38 (H.E., 200x)

Figura 39. Medula cervical, meningomielite, etiologia indeterminada. Observar a grande quantidade de células mononucleares (seta). Stenella clymene Caso No. 88 (H.E., 100x)

Figura 40. Retirada do encéfalo através de pequena janela feita na região posterior do crânio. Pontoporia blainvillei

Figura 41. Baço, hiperplasia linfóide reativa. Stenella clymene - Caso No. 88 (H.E., 40x) 
Figura 36a
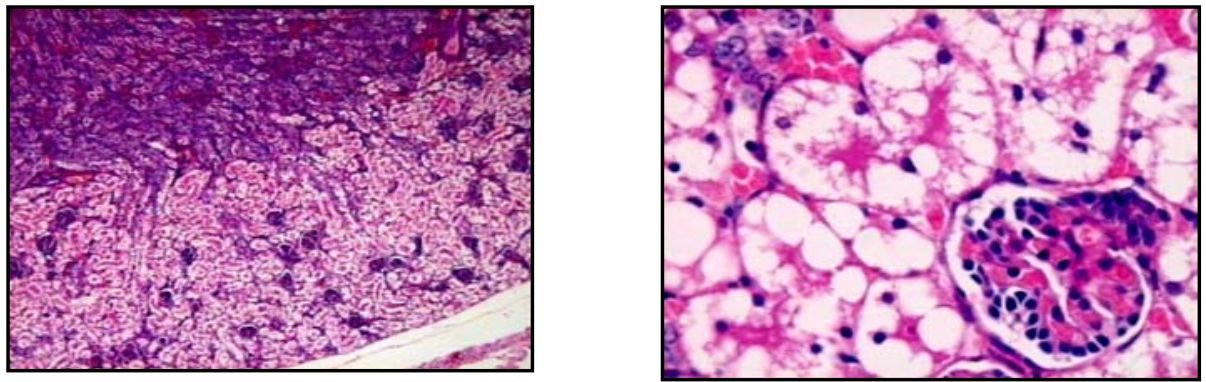

Figura 36b
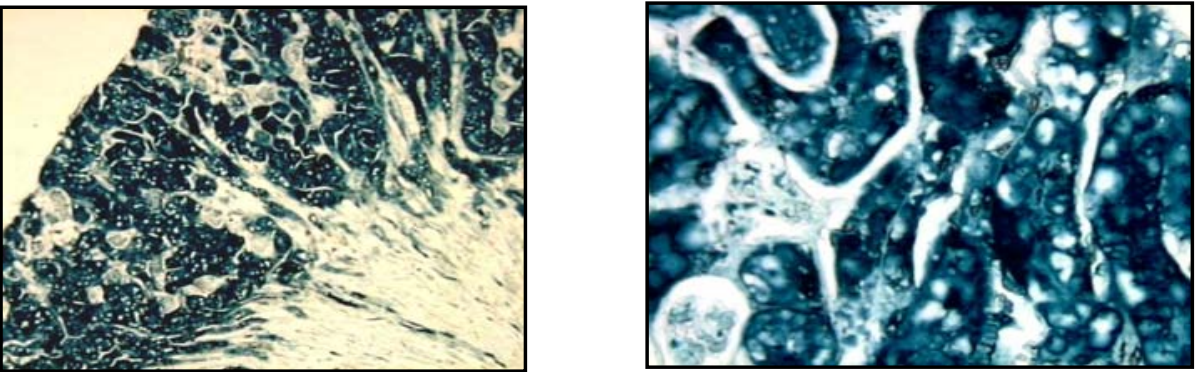

Figura 37b

Figura 37a

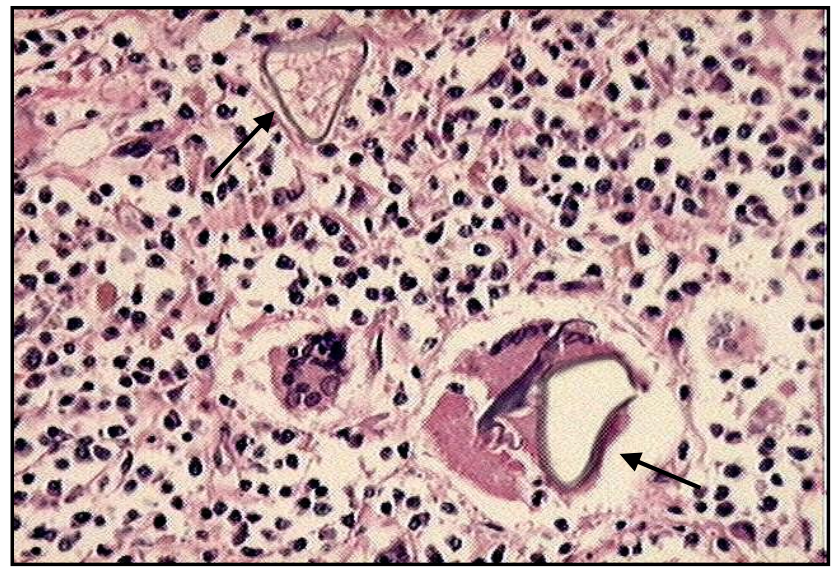

Figura 38

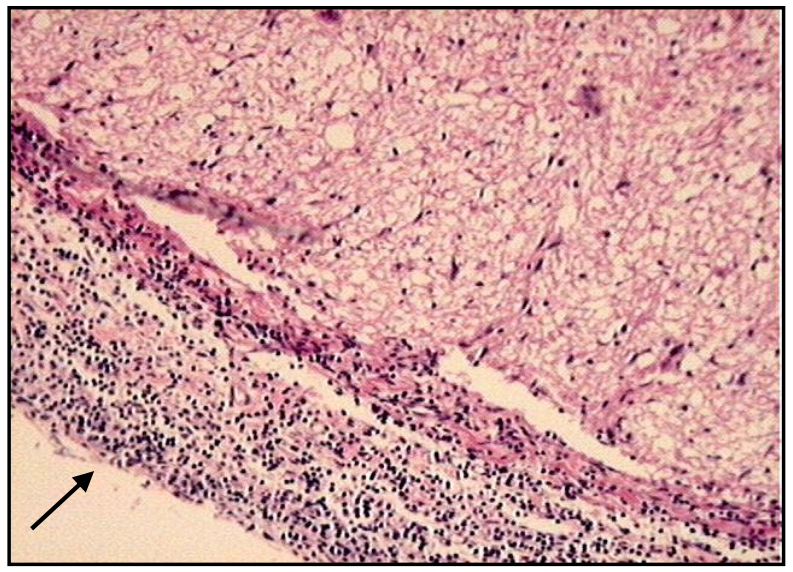

Figura 39

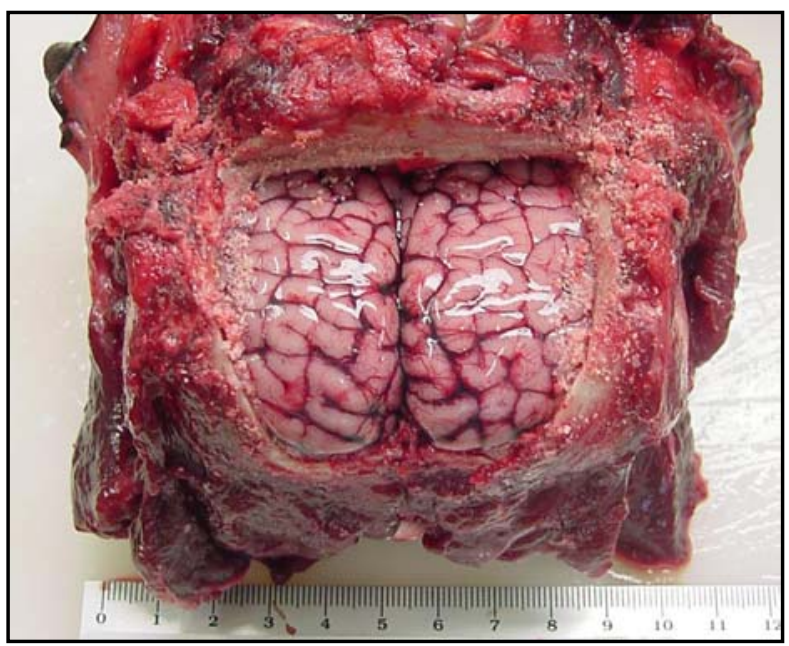

Figura 40

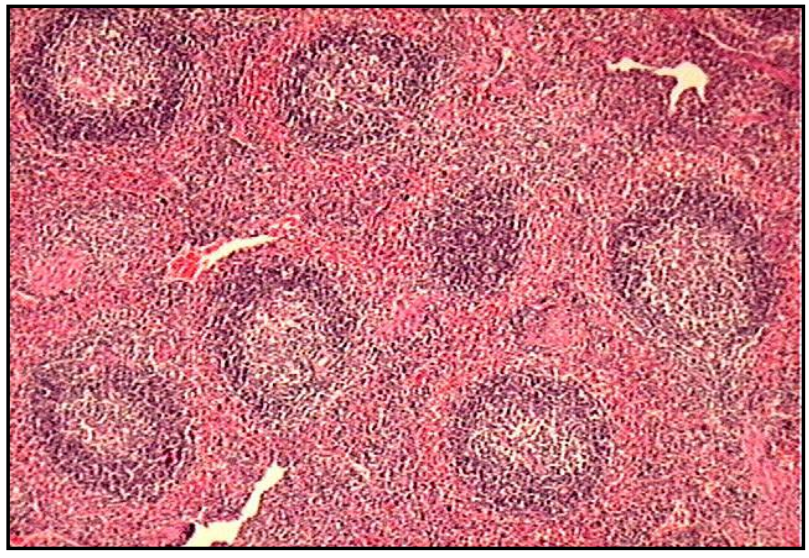


Figura 42. Rim, glomerulonefrite membranosa. Notar espessamento da membrana do tufo glomerular. Arctocephalus tropicalis - Caso No. 20 (H.E., 200x)

Figura 43. Rim, constatação da glomerulonefrite membranosa. Arctocephalus tropicalis Caso No. 20 (PAS, 200x)

Figura 44. Intestino, microabscessos criptais. Pontoporia blainvillei - Caso No. 48 (H.E., 100 x)

Figura 45. Intestino, detalhe da Figura 44. Pontoporia blainvillei - Caso No. 48 (H.E., 400 x)

Figura 46. Pulmão, vasculite fibrinóide. Pontoporia blainvillei - Caso No. 34 (H.E., 200x)

Figura 47. Baço, esplenite, aguda, moderada.Notar linfocitólise centro-folicular. Arctocephalus tropicalis - Caso No. 55 (H.E., 40x) 


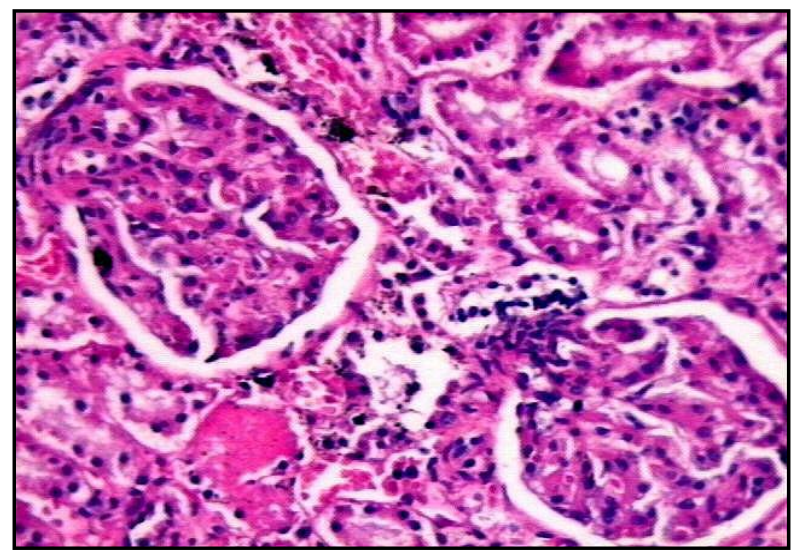

Figura 42

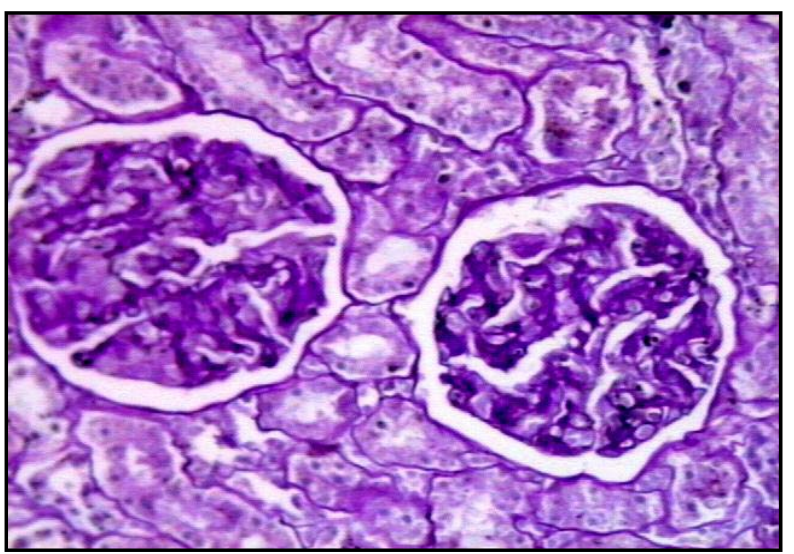

Figura 43

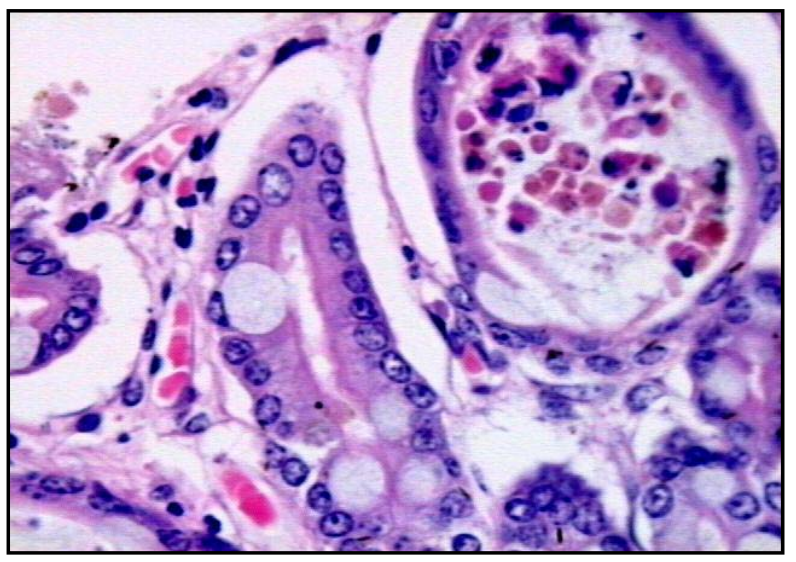

Figura 44

Figura 45
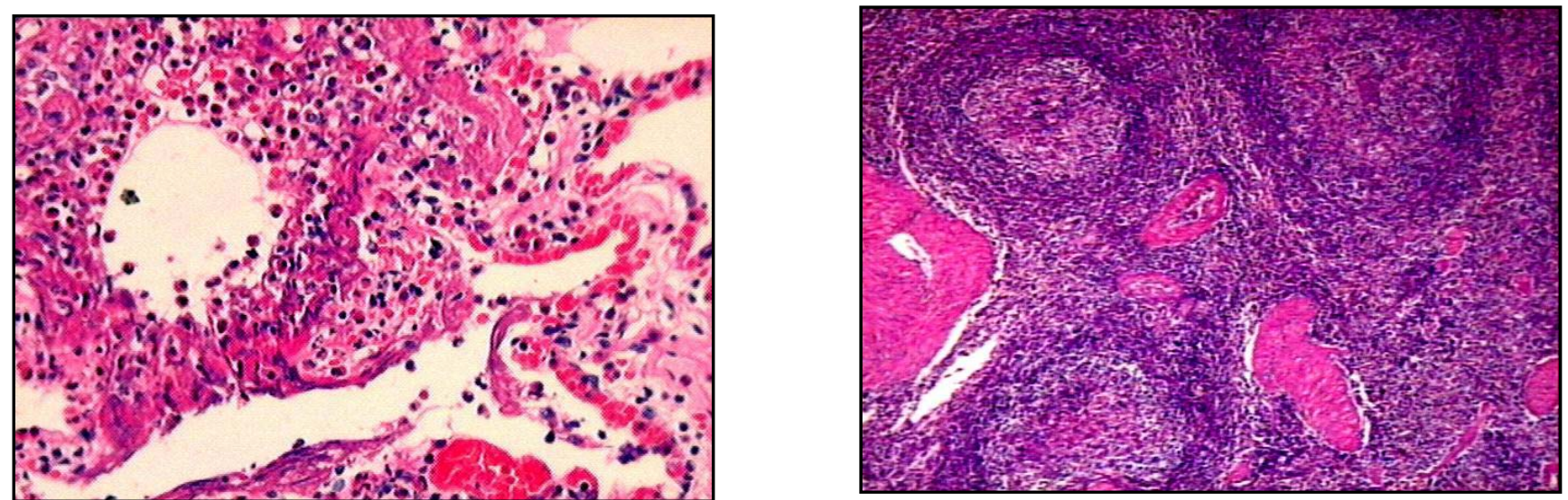

Figura 46 


\section{DISCUSSÃO}

Na presente discussão serão abordados os processos mais relevantes responsáveis pelo óbito dos animais, além de alguns dos processos mórbidos secundários presentes, quando da morte dos indivíduos.

De acordo com a sistematização proposta por Montali (1991), apresentada no ANEXO II, as causas de morte observadas nos cetáceos analisados foram: respiratório, asfixia; respiratório, pneumonia; respiratório, pneumonia, parasitária; respiratório, pneumonia, aspirativa; respiratório, pneumonia, intersticial; respiratório, pleuropneumonia; metabólico, estresse; metabólico, lipidose hepato-renal; infeccioso, bacteriano; infeccioso, agente indeterminado; trauma, vandalismo; indeterminado.

Por sua vez, as causas de morte observadas nos pinípedes analisados foram: respiratório, pneumonia, intersticial; respiratório, pneumonia, parasitária; respiratório, pleuropneumonia; respiratório, broncopneumonia; respiratório, pneumonia, lobar; respiratório, pneumonia, bacteriana; respiratório, asfixia; metabólico, estresse; metabólico, hipotermia; digestivo, enterite; urinário; pielonefrite; síndrome, colapso; nutricional, caquexia; físico, queimadura; trauma, vandalismo; indeterminado, autólise.

\subsection{Respiratório}

Em estudo semelhante ao realizado aqui, Siebert e colaboradores (2001) fizeram o exame histopatológico de 133 odontocetos (71 encalhes e 62 capturas acidentais) da espécie Phocoena phocoena, provenientes das costas do Mar Báltico e do Mar do Norte. A maioria das lesões encontradas por estes autores relaciona-se com o sistema respiratório, uma vez que a pneumonia foi considerada como a causa da morte de $46 \%$ (32/71) dos animais provenientes de encalhes, sendo que $62,4 \%$ (83/133) apresentaram parasitas pulmonares. Os exames bacteriológicos feitos sugeriram que 
as pneumonias foram causadas por infecção bacteriana secundária, e não somente pela infestação parasitária dos pulmões. Os Streptococcus Beta-hemolíticos foram considerados os principais agentes etiológicos do estudo acima mencionado.

Na investigação post mortem de 25 cetáceos realizada por Di Guardo et al., (1995), as lesões mais freqüentemente detectadas foram também as pneumonias, que ocorreram em $68 \%$ dos casos, seguidas de doenças parasitárias em 44\%. Outras afecções inespecíficas encontradas incluíram enterites, hepatites, nefrite intersticial e encefalite. A infecção pelo Morbilivirus foi detectada em quatro casos.

Os achados, predominantemente vinculados ao sistema respiratório, dos autores mencionados acima coincidem com aqueles verificados neste trabalho. Discute-se a seguir as causas de morte de origem respiratória de maior relevância reportadas em nosso levantamento.

\subsubsection{Respiratório, asfixia}

Das 79 amostras de cetáceos analisadas, 76\% (60/79) morreram como conseqüência da asfixia após aprisionamento em redes de pesca.

A determinação da causa de morte por asfixia decorrente de enrredamento pode ser muito difícil. Os critérios para o diagnóstico da morte por captura acidental em rede de pesca são revisados por Kuiken (1994). Segundo Gulland e colaboradores (2001), em odontocetos enrredados as lesões pulmonares indicativas de afogamento são inconsistentes, pois estes animais quando mortos em redes raramente apresentam líquido nos pulmões, presumivelmente devido aos seus reflexos de adaptação ao mergulho muito bem desenvolvidos.

Aparentemente, durante o processo de evolução, os cetáceos perderam o reflexo direto de respiração na presença de concentrações sangüíneas elevadas de dióxido de carbono (RIDGWAY, 1972). Hartmann et al., (1994) discutem que se este é o único mecanismo regulador da respiração 
nestes animais, um cetáceo preso debaixo d'água não inalaria líquido por reflexo involuntário, como faria um mamifero terrestre.

De acordo com a classificação de França (1998) a asfixia está sub-dividida em:

- Asfixia pura: manifestada pela anoxemia e hipercapnéia.
a) Asfixia em ambientes por gases irrespiráveis;
b) Obstaculação à penetração do ar nas vias respiratórias;
c) Transformação do meio gasoso em meio líquido (afogamento);
d) Transformação do meio gasoso em meio sólido (soterramento).

- Asfixia complexa: constrição das vias respiratórias com anoxemia e excesso de gás carbônico, interrupção da circulação cerebral e inibição dos elementos nervosos do pescoço por compressão.
a) Constrição passiva do pescoço (enforcamento);
b) Constrição ativa do pescoço (estrangulamento).

Este mesmo autor menciona que nos afogamentos de humanos, além dos sinais cadavéricos externos, observam-se alterações internas vinculadas à presença de água e corpos estranhos nas vias aéreas inferiores. Dependendo do tipo de elemento onde ocorreu a morte, tipos diferentes de corpos estranhos microscópicos podem ser observados como, por exemplo, fungos, vegetais, minerais e plâncton. $\mathrm{O}$ diagnóstico de afogamento é baseado no histórico, lesões encontradas durante a necropsia e na evidência de inalação de água.

A morte por asfixia em cetáceos ocorre na ausência da inspiração involuntária final, não havendo, portanto, a invasão das vias aéreas pela água (HARTMANN, et al., 1994). Dessa forma, considerando a classificação acima descrita (FRANÇA, 1998), somando-se ao fato de que não foram encontrados corpos estranhos evidenciando a inalação de água, podemos concluir que a asfixia em 
cetáceos enrredados é do tipo "pura por obstrução". Ainda, de acordo com Lipscomb (1994) a associação de evidências de enrredamento ante mortem, o encontro histopatológico de congestão e edema pulmonares, somando-se à ausência de quaisquer outras causas de morte evidentes, permitem a definição da causa mortis como sendo asfixia.

Na exclusão de outras causas de morte, Kuiken e colaboradores (1994) e Kuiken (1994), além do quadro congestivo pulmonar utilizam a evidência de alimentação recente e as marcas de rede para o diagnóstico de captura acidental.

Em nosso trabalho classificou-se a causa de morte dos cetáceos com histórico de enrredamento como "respiratório, asfixia", uma vez que estes animais também apresentaram o quadro respiratório congestivo característico descrito por Lipscomb (1994) e Kuiken (1994) (Figuras 15 e 16).

Um aspecto que merece abordagem detalhada é o fato de que, além da congestão pulmonar moderada a severa, diversos animais apresentaram outros achados que confirmaram a existência de quadros mórbidos estabelecidos anteriores à captura. Existe uma tendência de associar-se que animais capturados acidentalmente são saudáveis. Nossos achados constatam porém que 23,6\% (13/55) dos cetáceos da espécie Pontoporia blainvillei capturados em redes de pesca apresentaram afecções, não necessariamente fatais, que podem ter proporcionado algum desconforto, conseqüentemente dificultando a caça e estimulando-os a alimentarem-se nas redes (Tabela 10). Independentemente dessas ponderações, não se descarta a possibilidade de que a alimentação nas redes seja um comportamento adquirido ou ainda que os animais não detectem as redes, atravessando-as e fazendo com que a captura seja realmente acidental. De acordo com o ANEXO III, observa-se ainda que a maioria dos animais capturados são indivíduos jovens, constatando o que relata Ott et al., (2002). 
Tabela 10. Correlação dos casos da espécie Pontoporia blainvillei que apresentaram quadros mórbidos anteriores à morte por captura acidental, distribuídos pelo Caso No. e afecção encontrada. Sudeste e sul do Brasil, 1997 - 2002

\begin{tabular}{|c|l|}
\hline Caso No. & \multicolumn{1}{|c|}{ Afecção } \\
\hline \hline 17 & Hepatite granulocítica difusa moderada. \\
\hline 19 & Pleuropneumonia, plasmocitária, mista, moderada a severa. \\
\hline 23 & Edema sub-pleural associado à pneumonia lobar moderada por C. E. \\
\hline 25 & $\begin{array}{l}\text { Pneumonia, intersticial, aguda, multifocal, moderada. } \\
\text { Enterite, plasmocitária, difusa, moderada. }\end{array}$ \\
\hline 49 & $\begin{array}{l}\text { Pleuropneumonia, crônica, difusa, moderada. Hepatite, periportal, aguda, moderada } \\
\text { associada à hiperplasia ductal severa. }\end{array}$ \\
\hline 53 & Pneumonia, focal, piogranulomatosa. \\
\hline 56 & Enterite, linfoplasmocitária, multifocal, moderada, com áreas de calcificação da sub-mucosa. \\
\hline 57 & Periesplenite por bactérias Gram negativas. \\
\hline 60 & Peritonite, difusa, granulocítica, moderada. \\
\hline 63 & Enterite, submucosa, crônica, difusa, moderada, predominantemente mononuclear. \\
\hline 67 & Linfadenite piogranulomatosa multifocal moderada. \\
\hline 72 & Pneumonia, catarral, moderada. \\
\hline 98 & Cicatriz abdominal. Pleuropneumonia, crônica, difusa, moderada. Fibrose perihepática. \\
\hline
\end{tabular}

O caso No. 98, um macho jovem de Pontoporia blainvillei capturado acidentalmente, apresentou uma cicatriz recente no abdômen, possivelmente causada por um objeto contundente, que atingiu o fígado e cruzou o diafragma em direção à cavidade torácica. 0 fígado deste animal foi analisado sob as colorações histoquímicas de Perls e Tricrômico de Masson, onde se obteve resultados positivos para hemossiderose e fibroplasia respectivamente, ilustrados nas Figuras 16, 17 e 18. Ainda, foi observada hiperplasia ductal exuberante (Figura 19). Este indivíduo apresentou pleuropneumonia, crônica, difusa, moderada e o agente Micrococcus sp. foi isolado da efusão no hidrotórax. Tal achado bacteriológico confirma aquele obtido por Higgins (2000), que afirma que múltiplos organismos já foram reportados como agentes etiológicos em cetáceos, incluindo Staphylococcus, Pseudomonas e Micrococcus.

Ainda como exemplo de enfermidade anterior à captura mencionamos o macho adulto de Stenella frontalis (Caso No. 53), que foi capturado junto a outro macho (Caso No. 52), provavelmente 
do mesmo grupo, no litoral do Estado de São Paulo. Na análise microscópica, além das lesões típicas provocadas pelo enrredamento, o animal apresentou linfadenite purulenta e pneumonia abscedante multifocal com extensa fibroplasia. Apresentou também crustáceos (Cirripedia:Lepadomorpha) presos entre os dentes e a gengiva. As alterações encontradas sugerem que este indivíduo sofresse de um processo crônico, tornando-o debilitado e vulnerável (RUOPPOLO et al., 2002). Aznar et al., (1994) discutem que a diminuição da movimentação de um cetáceo doente e a redução das capacidades regenerativa e imune da pele favorecem a colonização por crustáceos. No presente estudo, os crustáceos encontrados eram adultos. Tal fato, associado aos achados histopatológicos compatíveis com enfermidade crônica, sugere que o cetáceo acometido poderia estar lento há algum tempo, uma vez que a colonização cutânea destes crustáceos se faz através de uma larva.

Durante o processo de enrredamento, lesões podem ocorrer ao invés da morte imediata. Ramos et al., (2001) relatam a captura acidental de um macho de Sotalia fluviatilis no norte do Estado do Rio de Janeiro apresentando lesões ósseas crônicas, indicativas de interação com a pesca. Este indivíduo apresentou lacerações parcialmente cicatrizadas ao redor da circunferência do rostro, deslocamento e oclusão de alvéolos dentários e periostite discreta, devido à presença de nylon 0,5 $\mathrm{mm}$. Este indício, juntamente com o relato de pescadores da Baixada Santista, garante que alguns animais podem sobreviver à interação com as redes de pesca (BERTOZZI, comunicação pessoal).

Pinípedes também já foram reportados devido à sua associação com a pesca (STANLEY; SHAFFER, 1995; WADA et al., 1991; WICKENS, 1994), porém não foram encontrados relatos que descrevessem as lesões pulmonares provocadas pelo enrredamento. Em nosso estudo houve um pinípede capturado acidentalmente em uma rede de espera destinada à pesquisa na llha Rei George, na Antártica. O animal envolvido foi uma fêmea jovem de foca-de-weddell (Leptonychotes weddellii) e este não apresentou o quadro pulmonar congestivo esperado, comumente observado nos cetáceos. As 
demais lesões encontradas incluem enterite plasmocitária difusa moderada e hipoplasia linfóide esplênica moderada, que pode estar relacionada com a resposta orgânica do indivíduo à enterite.

Dessa forma, em virtude da ausência de respostas conclusivas à questão da existência de fatores predisponentes ao enrredamento, faz-se necessário que os grupos de pesquisa que realizam o monitoramento da captura acidental de animais em redes de pesca façam uma abordagem multidisciplinar dos indivíduos necropsiados, buscando informações que possam colaborar para uma maior compreensão dos processos biológicos e patológicos que os acometem e os predispõe à morte nas redes.

\subsubsection{Morte em decorrência de outras afeç̧ões respiratórias}

De acordo com Dungworth (1993) a resposta inflamatória dos pulmões varia de acordo com a natureza do agente causal, sua distribuição e persistência. As pneumonias podem ser classificadas, com base temporal, em agudas, subagudas, ou crônicas, de acordo com a sua etiologia ou fatores morfológicos. Este autor menciona que morfologicamente existem dois caminhos para a classificação das pneumonias:

a) De acordo com o tipo de infiltrado inflamatório: pneumonias exsudativas, com a repleção dos alvéolos por exsudato com característica catarral, fibrinosa, supurativa, hemorrágica, necrotizante e proliferativa;

b) De acordo com o local inicial de envolvimento e padrão de evolução da lesão: broncopneumonia, pneumonia lobar e pneumonia intersticial.

Dungworth (1993) menciona ainda que as pneumonias agudas são comumente de etiologia infecciosa, de natureza exsudativa e de padrão broncopneumônico. Pneumonias crônicas provém de causas várias, sendo mais comumente de natureza proliferativa e padrão intersticial. 


\subsubsection{Respiratório, pneumonia, intersticial}

Em 7,2\% (8/110) dos casos examinados determinou-se a causa de morte como respiratório, pneumonia, intersticial. Os indivíduos acometidos são 2,5\% (2/79) dos cetáceos e 19,3\% (6/31) dos pinípedes (Figuras 20 e 21).

As pneumonias intersticiais são condições inflamatórias nas quais predominam respostas exsudativas e proliferativas envolvendo as paredes alveolares. Uma variedade de agentes pode produzir danos agudos e difusos a estas estruturas, causando uma fase inicial de exsudação intraalveolar, que é rapidamente seguida por respostas proliferativas e fibrosantes. 0 dano pulmonar agudo pode ser causado por, ou estar associado à, condições como severas pneumonias de etiologia infecciosa, danos químicos, pancreatite aguda, "shock" ou septicemia. Clinicamente o fator comum é a dificuldade respiratória. A ausência óbvia de evolução das lesões dentro e ao redor dos brônquios e bronquíolos é o que diferencia esta condição das broncopneumonias (DUNGWORTH, 1993).

Nos pinípedes que vieram a óbito devido à pneumonia intersticial, esta se apresentou desde aguda até crônica, nos diferentes indivíduos. Em 16,6\% (1/6) dos pinípedes acometidos, observou-se a pneumonia parasitária concomitante à pneumonia intersticial, sendo que esta condição poderia ter evoluído a partir da presença destes organismos. Ainda, 12,9\% (4/31) apresentaram pneumonia intersticial, sem que este processo tenha sido classificado como a causa primária da morte.

\subsubsection{Pneumonias bacterianas}

O aparelho respiratório encabeça a lista dos sistemas orgânicos do qual foi feito, o maior número de isolamentos de bactérias patogênicas em cetáceos e pinípedes (DUNN et al., 2001). As bactérias mais comumente associadas às pneumonias são semelhantes em pinípedes e cetáceos, e incluem: Staphylococcus sp., Streptococcus sp., Pseudomonas sp., Salmonella sp., Escherichia coli. É relevante notar que as pneumonias bacterianas ocorrem freqüentemente como seqüelas de infestações 
parasitárias maciças em animais de vida livre e de encalhes. (DUNN, 1990; DUNN et al., 2001; HIGGINS 2000; HOWARD et al., 1983a).

Em nosso trabalho, as pneumonias bacterianas foram diagnosticadas em 6,4\% (2/31) dos pinípedes (Casos No. 41 e 107). Os agentes envolvidos foram Klebsiella pneumoniae e Morganella morganii, respectivamente.

O caso No. 41 envolveu um indivíduo encalhado vivo e encaminhado a centro de reabilitação, vindo a óbito 48 horas após o ingresso. Neste caso isolou-se o bacilo Gram-negativo Klebsiella pneumoniae de fragmento pulmonar colhido durante a necropsia. As lesões observadas no pulmão deste indivíduo incluíram pneumonia fibrinosa associada a carneificação e piogranulomas multifocais, indicando afeç̧ão crônica.

Higgins (2000) relata a ocorrência de Klebsiella pneumoniae no sistema respiratório de leãomarinho-da-Califórnia (Zalophus californianus).

As infecções por Klebsiella spp., agentes pertencentes à família Enterobacteriaceae, são consideradas oportunistas. Estes organismos são comumente encontrados no trato digestivo. A Klebsiella pneumoniae tem sido correlacionada com sérios casos de pneumonia e alta mortalidade, podendo evoluir para septicemias (SCHWARTZ; GEYER, 1997).

O patógeno também oportunista Morganella morganii foi isolado em fragmento de pulmão no caso No. 107, envolvendo um pinípede caquético, encalhado na Praia Grande, em São Paulo (Figura 4). Este animal apresentou pneumonia, fibrinohemorrágica, aguda, severa, com a evidenciação de colônias de bactérias. Higgins (2000) menciona o isolamento deste agente nos sistemas tegumentar e digestivo de cetáceos, porém não há registros deste organismo no sistema respiratório de pinípedes. A necropsia deste $A$. tropicalis revelou também fibrose cardíaca moderada. 0 exame histoquímico baseado na técnica do Tricrômico de Masson evidenciou a fibroplasia (Figuras 22 e 23). Ainda, neste 
mesmo caso realizaram-se as técnicas do Tricrômico de Masson e Vermelho Congo para o fígado, que também foi positivo para fibroplasia. Como achado incidental neste animal diagnosticou-se Sarcocystis spp. no diafragma e musculatura esquelética. Dailey (2001) menciona que Sarcocystis richardi foi diagnosticado no diafragma de Phoca vitulina, e ainda que o protozoário já foi reportado em Zalophus californianus, Erignathus barbatus, Hydrurga leptonyx, Phoca hispida, Arctocephalus gazella e Callorhinus ursinus.

Este mesmo autor relata que Sarcocystis spp. não causa sintomas, assim como nos cetáceos, quando localizado na musculatura. Entretanto, S. neurona foi encontrado recentemente no tecido cerebral de Phoca vitulina associado à encefalite (LA POINTE et al., 1998). Não foram encontrados relatos sobre a ocorrência de Sarcocystis na espécie $A$. tropicalis.

Os dois casos de pneumonia bacteriana apresentados aqui envolveram lobos-marinhos da espécie A. tropicalis. As colônias reprodutivas desta espécie estão distribuídas na convergência subantártica, sendo comum observar machos, e mais raramente fêmeas, nas costas sul e sudeste brasileiras durante os meses de inverno (REEVES et al., 1992). Estes animais viajam grandes distâncias e o comprometimento sanitário pode levar à caquexia e à imunodepressão, fazendo com que os indivíduos estejam suscetíveis a qualquer tipo de infecção. Na exaustão eles vêm à areia e terminam morrendo em praias brasileiras, muitas vezes por infecções oportunistas.

Dunn et al., (2001) mencionam que os pesquisadores envolvidos nesta área de atuação devem estar sempre preparados para diagnosticar doenças bacterianas previamente não reportadas em mamíferos marinhos, pois comumente existem achados não publicados, ou então publicados fora da área de interesse, ou ainda que são encontrados em material bibliográfico de difícil acesso. 


\subsubsection{Respiratório, pneumonia aspirativa}

Em 100\% (2/2) dos casos analisados de P. blainvillei que encalharam vivas (Casos No. 48 e 91) e foram encaminhadas a centros de reabilitação, diagnosticou-se a pneumonia aspirativa. Os achados microscópicos em comum incluem congestão, pneumonia esfoliativa difusa moderada e presença de material particulado nos espaços alveolares. No Caso No. 48 nota-se a presença moderada de macrófagos espumosos fagocitando partículas de gordura (Figuras 24 e 25).

As pneumonias aspirativas são causadas pela inspiração de material exógeno, comumente na forma líquida. Dungworth (1993) descreve que o tipo de resposta do organismo depende de três fatores: da natureza do material aspirado; das bactérias carreadas por ele; e da distribuição deste material nos pulmões. Quanto mais ampla a distribuição do material exógeno, mais grave será a apresentação do quadro clínico, culminando com a morte em até 24 horas.

É muito comum a administração de dieta pastosa através de sondagem gástrica na reabilitação de cetáceos jovens, como ocorreu nos casos observados aqui, este fato predispõe à ocorrência de pneumonias aspirativas nestas espécies.

\subsubsection{Respiratório, pneumonia, parasitária}

Os pulmões estão na via das migrações parasitárias, e os vários parasitos que passam através deles causam graus variados de dano tecidual, de acordo com a natureza e a intensidade da interação parasita-hospedeiro. Freqüentemente as lesões produzidas por esta migração são de significância mínima e de fácil resolução, porém existem exceções. Lesões pulmonares severas, e algumas vezes fatais, podem ocorrer se o número ou o tamanho dos parasitas migrando ao mesmo tempo for grande. Podem ocorrer ainda reações de hipersensibilidade quando houver exposição prévia do hospedeiro natural ou pela infecção de um hospedeiro não adaptado (DUNGWORTH, 1993). 


\section{- Cetáceos:}

Pôde-se observar a pneumonia parasitária como causa primária da morte de 3,7\% (3/79) dos odontocetos analisados. Duas S. fluviatilis (Casos No. 8 e 43) (Figuras 26 a 29) e um T. truncatus (Caso No. 7) foram as espécies afetadas.

À análise do pulmão do T. truncatus (Caso No. 7) diversos tipos de lesão foram observados, e estas incluem pneumonia, intersticial, crônica, difusa, moderada; pneumonia, granulomatosa, parasitária e pneumonia, abscedante, moderada (Figuras 12 e 13). Destaca-se ainda a hiperplasia linfóide marcante associada a balanite, crônica, multifocal, coalescente, moderada (Figuras 10 e 11), observada neste animal. Este processo continua sendo motivo de estudo, na tentativa de elucidação de sua causa etiológica específica.

Dos exemplares analisados da espécie S. fluviatilis, $80 \%$ (4/5) foram encalhes e $20 \%(1 / 5)$ foram capturados acidentalmente em rede de pesca. Todos $(100 \%-5 / 5)$ os exemplares examinados vieram a óbito apresentando lesões pulmonares relacionadas com a presença de parasitos, sendo que os nematóides pulmonares da espécie Halocercus brasiliensis foram identificados em $40 \%(2 / 5)$ dos casos (Casos №. 43 e 51).

O Caso No. 8 teve como causa da morte a pneumonia parasitária. A lesão pulmonar consistiu de pneumonia, intersticial, crônica, difusa, moderada a severa, com a presença de parasitos Metastrongilidae. Este animal apresentou também gastrite, eosinofílica, focal, moderada a severa. 0 segundo indivíduo da espécie $S$. fluviatilis que veio a óbito devido à pneumonia parasitária é o Caso No. 43, este apresentou broncopneumonia, purulenta, difusa, moderada a severa. Ainda, o achado hepático de leucocitose, eosinofílica, sinusoidal, somando-se à esplenite, eosinofílica, difusa, moderada e à linfadenite, eosinofílica, difusa, moderada a severa, indicam que havia uma grande quantidade de eosinófilos circulantes. 
O Caso No. 2 apresentou pleuropneumonia, fibrinosa, moderada e pneumonia, intersticial, aguda, multifocal, moderada.

O Caso No. 3, um filhote de Sotalia, demonstrou lesões tão severas quanto as apresentadas anteriormente, e estas incluem além de broncopneumonia, também uma pneumonia lobular fibrinopurulenta difusa, moderada a severa, com infiltrado inflamatório misto contendo grande quantidade de eosinófilos. Cetáceos podem infectar-se por parasitos em idades precoces, Dailey et al., (1991) relataram a infecção prenatal dos pulmões de um T. truncatus pelos nematóides do gênero Halocercus.

O Caso No. 51, apesar de haver tido a morte induzida pela captura em rede de pesca, apresentava pneumonia, intersticial, eosinofílica, difusa, moderada, indicando a presença de parasitos.

No estudo de Jepson et al., (2000), analisou-se a patologia pulmonar de 197 Phocoena phocoena provenientes de encalhes e capturas acidentais nas costas inglesas. Estes autores constataram a presença de parasitas pulmonares em $69 \%$ (135/197) dos casos. As lesões observadas neste estudo incluíram 31,4 \% (62/197) de bronquites e bronquiolites, subagudas a crônicas, discretas a severas; $57,3 \%(113 / 197)$ de pneumonias, intersticiais, crônicas, granulomatosas, discretas a severas, e em 17,2\% (34/197) dos casos observaram vasculites e trombovasculites, discretas a severas dos vasos pulmonares, que foram atribuídas à infecção pelos nematóides. Em 35 casos foram observadas pneumonias purulentas, que foram atribuídas à infecção bacteriana secundária ou septicemias.

De acordo com Dailey (2001), os nematóides infectando os pulmões, vasos sanguíneos pulmonares, espaços auditivos e seios aéreos de cetáceos pertencem a duas famílias (Pseudaliidae e Crassicaudidae), das quais quatro gêneros (Halocercus, Pharurus, Pseudalius e Stenurus) são os mais comuns. Os sintomas da infestação pulmonar variam de acordo com o hospedeiro e a espécie do 
parasita, assim como com a intensidade de infecção. Eles incluem tosse, dispnéia, letargia e potencialmente a morte (MOSER; RHINEHART, 1993).

No Brasil, de acordo com Santos et al., (1996) e Marigo et al., (2000) é comum a ocorrência de Halocercus brasiliensis infectando os pulmões de Sotalia fluviatilis, tendo sido reportado no RJ, SP e Paraná. De acordo com a freqüência e a severidade das lesões observadas, esta parasitose é uma condição debilitante importante para a espécie.

\section{- Pinípedes:}

A pneumonia parasitária foi diagnosticada em 6,4\% (2/31) dos animais examinados.

Um macho jovem da espécie $A$. australis (Caso No. 82) apresentou, além da pneumonia parasitária (Figuras 30 e 31), broncopneumonia e pneumonia intersticial, ambas agudas, multifocais, moderadas. Já no caso No. 110, o animal apresentou resposta fibrinosa exuberante, associada a edema e extensas áreas de congestão e hemorragia.

De acordo com Dailey (2001) espécies pertencentes a duas famílias de nematóides infectam o sistema respiratório de pinípedes, sendo estas Filaroididae: Filaroides (Parafilaroides) spp. e Crenosomatidae: Otostrongylus circumlitus. Filaroides spp. são cosmopolitas em focídeos e otarídeos, e freqüentemente contribuem para pneumonias em animais encalhados. Sua significância clínica, quando comparada com a infecção bacteriana concorrente, é freqüentemente obscura, apesar do Filaroides decorus isoladamente ser patogênico em leões-marinhos da Califórnia (GERBER et al., 1993).

Além dos casos de pneumonia parasitária como causa primária da morte, outros 2 (2/31 6,4\%) animais apresentaram nematóides associados a lesões pulmonares. O Caso No. 1 apresentou bronquiectasia, fibrinohemorrágica, moderada, áreas de consolidação pulmonar, congestão e 
hemorragia moderadas. O Caso No. 29 além de parasitos da Família Anisakidae apresentou pneumonia, intersticial, difusa, moderada a severa, sendo esta pneumonia sua causa de morte.

Já o Caso No. 40 apresentou parasitos no espaço alveolar sem evidência de lesão nos fragmentos pulmonares examinados.

Parasitas pulmonares são freqüentes em pinípedes, sendo que em animais jovens causam lesões mais significativas, provavelmente devido à baixa imunidade.

Não existem outros relatos de parasitose pulmonar em pinípedes no Brasil para que possamos comparar a patogenia e a freqüência dos mesmos, indicando a necessidade de trabalhos complementares.

\subsubsection{Outros achados no sistema respiratório}

6.1.3.1 Pneumonia, crônica, granulomatosa induzida pela presença de corpo estranho - cristais de colesterol

Dos 60 animais da espécie Pontoporia blainvillei analisados, 91,6\% (55/60) foram provenientes da captura acidental, e 8,4\% (5/60) de encalhes. Do total, 16,6\% (10/60) apresentaram pneumonia crônica granulomatosa por corpo estranho, com graus de intensidade distintos, induzida pela presença de cristais de colesterol (Figuras 32 e 33), sendo que apenas 10\% (1/10) sofreram morte natural e não induzida pela captura acidental. Jones et al., (1996) sugerem que cristais de colesterol ocorrem como sub-produtos de necrose, revelando-se como espaços em branco deixados pelos cristais de colesterol dissolvidos pelos solventes utilizados nas preparações histológicas. Estes autores mencionam ainda que a origem do colesterol cristalizado nos tecidos provém do citoplasma decomposto e de membranas de células mortas em áreas onde ocorreu necrose de células ricas nesta substância. Tais áreas incluem focos hemorrágicos antigos, abscessos resolvidos e ateromas. $O$ único relato encontrado sobre a presença de cristais de colesterol em cetáceos foi o de Howard e colaboradores (1983b), onde 
mencionam a ocorrência de depósitos lipídicos no tecido cerebelar de um Delphinus delphis devido à presença de ovos de trematóides.

Os casos encontrados nesta pesquisa ocorreram exclusivamente na espécie $P$. blainvillei. Este fato sinaliza para a necessidade de estudos mais aprofundados direcionados à predisposição da ocorrência dos cristais de colesterol em Pontoporia blainvillei, assim como a determinação do real significado deste processo patológico nesta espécie de cetáceo.

\subsection{Metabólico}

\subsubsection{Metabólico, estresse}

Considerou-se a causa de morte como metabólico, estresse, em 1,2\% (1/79) dos cetáceos e em $25,8 \%$ (8/31) dos pinípedes estudados.

O cetáceo envolvido (Caso No. 37) foi uma fêmea da espécie Kogia breviceps, que encalhou junto a outro indivíduo, já morto, da mesma espécie, provavelmente sua mãe (Caso No. 36). 0 animal foi encaminhado a centro de reabilitação, vindo a óbito no terceiro dia. As lesões encontradas incluem depleção linfóide moderada, extensas áreas de hemorragia pulmonar e lipidose hepática severa.

A causa de morte dos pinípedes nos Casos No. 14, 99 e 100 provavelmente esteve vinculada ao estresse térmico. Após período de reabilitação os três animais encontravam-se aptos para liberação, o que sugere bom peso corporal. Os três casos envolveram a contenção em espaço pequeno (jaula de transporte) por longo período (> 8 horas), o que certamente gerou desconforto e nervosismo nos animais. No caso No. 16 o animal foi deixado sob o sol forte por oito horas aproximadamente, sendo reencaminhado ao centro de reabilitação em estado de choque. Nos casos No. 105 e 106 os animais foram colocados em jaula de transporte na noite anterior à liberação, sendo deixados nesta condição em uma noite de calor extremo. Foram encontrados mortos na manhã seguinte. Os achados em comum nestes casos incluem quadro congestivo e hemorrágico severo, e também depleção linfóide. 
A literatura sobre a resposta ao estresse em mamíferos identifica quatro principais pontos de interesse: fisiologia, endocrinologia, imunologia e neurologia. Existe sobreposição de cada um destes pontos durante a resposta do organismo a um agente estressor, já que hormônios alteram processos biológicos e a resposta imunológica, assim como o estímulo neurológico induz respostas fisiológicas e endócrinas, e estas também estão ligadas à ativação das respostas inflamatórias. Em cada uma das categorias é importante considerar se a resposta é aguda ou crônica, e se as alterações orgânicas associadas são benéficas ou mais agressivas que o estressor original (ST. AUBIN; DIERAUF, 2001).

A sobrevivência do organismo depende da regulação em retroalimentação entre estes sistemas, e quando isto não ocorre ou o estímulo é levado à exaustão, o resultado é o distresse e possivelmente a morte (BREAZILE, 1987; ST. AUBIN; DIERAUF, 2001).

Os estágios agudos do estresse são mais freqüentemente diagnosticados através de amostras sangüíneas. As alterações típicas incluem cetose, hiperlipidemia, hiperglicemia, hiperaminoacidemia e acidose metabólica (BOSSART et al., 2001).

O estresse crônico pode ocorrer se os estressores forem freqüentes, intermitentes, e/ou repetitivos, produzindo uma de três respostas: 1) hábito, onde o a resposta ao estresse diminui em cada episódio; 2) sensibilização, onde o estresse aumenta em cada episódio; e 3) a dessensibilização, onde não há mudanças. No estresse crônico há a ativação permanente do eixo adrenal-hipotalâmicohipofisário, produzindo a secreção repetitiva de glicocorticóides. Este estímulo contínuo produz problemas na função reprodutiva, imunológica e no crescimento (ST. AUBIN; DIERAUF, 2001).

Exceto nos casos Casos No. 14, 37, 99 e 100, que envolveram o estresse agudo, os casos restantes envolveram pinípedes jovens, no seu primeiro ano de vida. Estes animais estiveram vinculados ao estresse crônico provavelmente devido a uma série de fatores biológicos que incluem a separação da mãe, com conseqüente menor disponibilidade de alimento, até o momento em que haja adaptação da dieta; perda de peso; desidratação; hipotermia; possível fuga de predadores, culminando 
com a saída do animal da água e possivelmente com a morte. Todos estes fatores induzindo estresse corroboram com o achado constante de depleção linfóide nos casos estudados, sugerindo a depressão imunológica. Este quadro esteve associado em diversas ocasiões com outros processos mórbidos concomitantes, como as pneumonias, intersticial, parasitária e lobar.

Estudos adicionais se fazem necessários para determinar a sensibilidade de tais indicadores do estresse em mamíferos marinhos.

\subsubsection{Metabólico, lipidose hepato-renal}

A lipidose hepato-renal foi diagnosticada em 2,5\% (2/79) dos cetáceos (casos No. 27 e 90) e estes encontram-se ilustrados nas Figuras 34 a 37. Em ambos casos observou-se lipidose severa em fígado e rim. O caso No. 27 apresentou ainda depleção linfóide severa.

A síndrome de lipidose-hepato renal foi descrita em primatas, nos animais domésticos e no homem (KELLY, 1993; LABER-LAIRD et al., 1987; LEITE, 2001; SÁ, 1999). O acúmulo de gordura, particularmente de triglicérides, no fígado pode ser causado por distúrbios nutricionais, hormonais, tóxicos, anóxicos ou hipóxicos do metabolismo hepático (KELLY, 1993). Os fatores predisponentes incluem obesidade, estresse, jejum, hipotireoidismo, agentes tóxicos e diabetes mellitus (GLIATTO; BRONSON, 1993; KELLY, 1993; LABER-LAIRD et al., 1987).

A patogênese do processo não é totalmente compreendida, porém algumas características têm sido comumente observadas nos primatas: severa esteatose hepática; esteatose renal moderada a severa; abrupta perda de peso; depleção linfóide esplênica moderada; evolução curta; anorexia; obesidade; alterações pancreáticas; maior suscetibilidade do sexo feminino e a ocorrência de criptas colônicas preenchidas por material eosinofílico (BRADY; MORTON, 1998; GLIATTO; BRONSON, 1993; LABER-LAIRD et al., 1987; LEITE, 2001; SÁ, 1999). 
O único relato encontrado na literatura envolvendo um cetáceo foi o de Gomercic e colaboradores (2000). Estes autores relatam a esteatose hepática severa, e conseqüente insuficiência, como a causa de morte de uma fêmea adulta de Tursiops truncatus, na Croácia. As lesões encontradas por estes autores estiveram relacionadas com a rápida perda da função hepática, resultando em acúmulo exacerbado de lipídios e necrose dos hepatócitos. Como conseqüência da hipofunção houve acúmulo de líquido no tecido subcutâneo, cavidades corpóreas e sistema nervoso central, sendo que o animal apresentou convulsões anteriores à morte.

Os casos estudados aqui não apresentaram histórico, ambos sendo animais provenientes de encalhes. Sabe-se que o indivíduo da espécie Stenella longirostris (Caso No. 27) é um filhote, porém não foi possível detalhar a idade do outro indivíduo. Kelly (1993) menciona que a infiltração gordurosa fisiológica pode ser observada em neonatos devido ao alto teor de gordura do leite de algumas espécies, o que é verdadeiro para os cetáceos. Porém nos casos observados aqui, além da esteatose hepática, observou-se severa lipidose renal, que é um achado patológico. Este indivíduo apresentou ainda peritonite infecciosa bacteriana causada por agentes Gram positivos.

Semelhantemente a outros processos descritos, acreditamos que trabalhos futuros sejam necessários para a identificação da real importância deste quadro em cetáceos, particularmente considerando o incremento dos programas de reabilitação de neonatos ao redor do mundo.

\subsection{Infeccioso}

O exemplar analisado da espécie Steno bredanensis (caso No. 38) teve como causa de morte processo de etiologia infecciosa, tendo sido isolado o Staphylococcus xylosus em seu sangue periférico. A septicemia por Staphylococcus sp. já foi reportada diversas vezes em cetáceos (DUNN et al., 2001; HIGGINS, 2000; HOWARD et al., 1983a). 
Amostras de gordura deste indivíduo (caso No. 38) foram analisadas por Yogui (2002). Neste estudo o autor determinou que as concentrações de PCB e DDT neste animal, encontrado morto no litoral paulista, apresentaram níveis elevados ( $\sum 26,7$ e $\sum$ 118,4 respectivamente) comparáveis com cetáceos de países desenvolvidos e, conseqüentemente mais industrializados.

Jepson e colaboradores (1999) investigaram a possível associação destas substâncias imunossupressoras com a mortalidade de cetáceos devido a doenças infecciosas. Através desta pesquisa estes autores puderam comprovar que o grupo de animais mortos devido a causas infectoparasitárias possuíam níveis elevados de PCBs $\left(\sum 25\right)$. Os agentes envolvidos na mortalidade dos animais não foram primariamente patogênicos, como alguns vírus, por exemplo, porém foram parasitas nematóides e bactérias como os Streptococcus, aos quais os animais provavelmente estiveram expostos toda a vida, sugerindo imunossupressão.

Os achados de Jepson et al., (1999) corroboram com a situação do animal estudado aqui, que apresentou quadro septicêmico somado à doença renal policística, abordada por Ruoppolo et al., (2001), como fator agravante de sua condição sanitária (Figuras 6 e 7). Este indivíduo apresentou ainda formações cutâneas verrucosas e esplenite parasitária, ilustradas pelas Figuras 8, 9 e 38. Cistos simples, presumivelmente adquiridos, são freqüentemente observados nos rins de várias espécies, particularmente em cães e suínos (JONES; HUNT, 1983). No entanto, o aspecto macroscópico policístico observado no animal em questão é compatível com a doença renal policística, anomalia congênita comum em humanos adultos. Nesta, os rins se apresentam como massas bilaterais compostas de estruturas císticas de tamanho variável, restando pouco parênquima funcional (COTRAN et al., 1999). Howard (1983) cita que rins císticos foram observados em golfinhos, sem evidências de lesão obstrutiva, sendo considerados anomalias de desenvolvimento.

O único exemplar de Stenella clymene (caso No. 88) analisado foi um animal que encalhou vivo, com dificuldade de natação e de equilíbrio na superfície, apresentando tremores, convulsão e 
morte 24 horas depois do encalhe. Este indivíduo exibiu meningomielite não-supurativa severa, possivelmente induzida por um agente infeccioso ainda não identificado, sendo ainda objeto de estudo (Figura 39).

Os relatos da ocorrência de meningoencefalites em cetáceos descritos na literatura envolvem dois agentes etiológicos. Brucella sp. foi relatada por Gonzalez et al., (2002), causando meningoencefalite não-supurativa crônica em três Stenella coeruleoalba encalhados vivos na costa da Escócia. O diagnóstico foi feito através de necropsia, histopatologia, bacteriologia e serologia.

O segundo agente envolvido nas encefalites não-supurativas é o Morbilivirus. As lesões encontradas nas morbiliviroses são apresentadas por Domigo et al., (1992) e Kennedy (1998). Além das meningoencefalites, as pneumonias bronquíolo-intersticiais e as encefalites foram encontradas em $72 \%$ (41/58) e 69\% (40/58) dos animais examinados por Domingo e colaboradores (1992), respectivamente.

No presente trabalho, amostras congeladas do cérebro do Stenella clymene foram encaminhadas ao Laboratório de Virologia Clínica e Molecular do Instituto de Ciências Biológicas (ICB II) e ao Departamento de Medicina Veterinária Preventiva e Saúde Animal da Faculdade de Medicina Veterinária e Zootecnia (VPS-FMVZ), ambos na Universidade de São Paulo, para a investigação, ainda em andamento, da ocorrência de Morbilivirus e Brucella, respectivamente, através da técnica da Reação da Polimerase em Cadeia (PCR).

\subsection{Considerações finais}

De acordo com os resultados obtidos nesta pesquisa, parece-nos muito importante seguir incentivando os grupos de estudo que trabalham em regiões costeiras a incrementar a colheita padronizada de amostras para estudos patológicos, pois só assim poderemos aprofundar nosso conhecimento sobre as enfermidades que afetam os mamíferos marinhos na costa sul-americana. 
Durante o desenvolvimento do projeto houve a dificuldade de exame do sistema nervoso central na maioria das necropsias, devido ao fato de que o estudo da craniometria é extremamente comum entre os pesquisadores de mamíferos marinhos. Nas necropsias realizadas pelos pesquisadores do LAPCOM (VPT-FMVZ-USP) foi possivel demonstrar a viabilidade da retirada do encéfalo preservando as estruturas ósseas necessárias para este tipo de estudo, inclusive com a disponibilização de material para estudos anatômicos no Instituto de Ciências Biomédicas (ICB III) da Universidade de São Paulo, através do projeto "Vascularização Cerebral de Cetáceos. Histomorfometria fibrosa de artérias cerebrais", realizado no Laboratório de Biologia Celular e Anatomia Funcional no Instituto de Ciências Biológicas da Universidade de São Paulo (Figura 40).

Ainda, cumpre ressaltar que as amostras utilizadas para a realização deste projeto complementaram o banco de tecidos de animais selvagens mantido pelo Registro de Patologia Comparada (RPC-LAPCOM-VPT-FMVZ-USP), formando dessa forma o primeiro acervo de tecidos de mamíferos marinhos disponível no Brasil. Este acervo permitirá a utilização do material a profissionais vinculados a instituições de pesquisa, de acordo com regras pré-estabelecidas (RUOPPOLO et al., 2002). Ressalta-se a importância da manutenção deste banco de material para futuros estudos retrospectivos, devido ao contínuo desenvolvimento de novas técnicas para o diagnóstico de enfermidades.

Finalmente, é importante mencionar que todo o material osteológico proveniente das necropsias realizadas em São Paulo foi encaminhado para maceração e tombamento no Museu de Zoologia da Universidade de São Paulo (MUZUSP) e no Museu de Pesca de Santos. 


\section{CONCLUSÕES}

- As lesões vinculadas ao sistema respiratório foram predominantes tanto nos cetáceos quanto nos pinípedes. Nos cetáceos, este fato deveu-se à grande porcentagem de animais analisados mortos em redes de pesca, cuja causa de morte foi asfixia. Independentemente deste fato, diversos indivíduos apresentaram quadros mórbidos anteriores à captura. Nos indivíduos da espécie Sotalia fluviatilis os problemas respiratórios ocorreram devido à incidência de parasitos pulmonares.

- Os processos respiratórios em pinípedes estiveram vinculados à imunossupressão decorrente da caquexia e das situações de estresse vividas pelos animais antes do encalhe e durante a reabilitação. A imunodepressão favoreceu o estabelecimento de infecções oportunistas. As lesões pulmonares nestes animais estiveram também associadas à, ou foram decorrentes da, presença de parasitos.

- Os achados anatomopatológicos nos indivíduos provenientes de capturas em redes de pesca foram acidentais, porém o estudo destes indivíduos pode fornecer informações valiosas sobre o estado sanitário das populações às quais eles fazem parte.

- $\quad$ encontro de cristais de colesterol exclusivamente nos pulmões de $P$. blainvillei sinaliza para a necessidade de estudos mais aprofundados direcionados à predisposição da ocorrência dos mesmos nesta espécie, assim como a determinação do real significado do processo patológico nestes animais.

- Os resultados alcançados aqui reforçam a necessidade da abordagem multidisciplinar dos animais encalhados e também dos capturados acidentalmente em redes de pesca, buscando informações que possam colaborar para uma maior compreensão dos processos patológicos que os acometem e os predispõe à morte. 


\section{REFERÊNCIAS}

AZNAR, F. J.; BALBUENA, J. A. E RAGA, J. A. Are epizoits biological indicators of a Western

Mediterranean striped dolphin die-off?? Diseases of Aquatic Organisms, v. 18, p. 159-163, 1994.

BARNES, L. G.; DOMNING, D. P.; RAY, C. E. Status of studies on fossil marine mammals. Marine Mammal Science, v. 1, n. 1, p. 15-53, 1985.

BASTIDA, R.; LOUREIRO, J.; QUSE, V.; BERNARDELLI, A.; RODRIGUEZ, D.; COSTA, E.

Tuberculosis in a wild subantartic fur seal from Argentina. Journal of Wildlife Diseases, v. 35, n. 4, p. 796-798, 1999.

BERNARDELLI, A.; BASTIDA, R.; LOUREIRO, J.; MICHELIS, H.; ROMANO, M. I.; CATALDI, A.; COSTA, E. Tuberculosis in sea lions and fur seals from the south-western Atlantic coast. Rev. sci. tech. Off. int. Epiz., v. 15, n. 3, p. 985-1005, 1996.

BOSSART, G. D.; REIDARSON, T. H.; DIERAUF, L. A.; DUFFIELD, D. A. Clinical pathology. In: DIERAUF, L. A.; GULLAND, F. M. D. (Ed.). Handbook of marine mammal medicine. 2. ed. Boca Raton: CRC Press, 2001. p. 383-436.

BOYD, I. L.; LOCKYER, C.; MARSH, H. D. Reproduction in marine mammals. In: REYNOLDS III, J. E.; ROMMEL, S. A. (Ed.). Biology of marine mammals. Washington and London: Smithsonian Institution Press, 1999. p. 218-286.

BREAZILE, J. E. Physiologic basis and consequences of distress in animals. Journal of the American Veterinary Medical Association, v. 191, p. 1212-1215, 1987.

BRITT, J. O.; HOWARD, E. B. Anatomic variants of marine mammals. In: HOWARD, E.B. (Ed.). Pathobiology of marine mammal diseases. Boca Raton, FL: CRC Press, 1983a. vol. 1. p. 7-45.

BRITT, J. O.; HOWARD, E. B. Virus diseases. In: HOWARD, E.B. (Ed.). Pathobiology of marine mammal diseases. Boca Raton, FL: CRC Press, 1983b. vol. 1. p. 47-68.

COTRAN, R. S.; KUMAR, V.; COLLINS, T. (Ed.) Robbins pathologic basis of disease. 6. ed. [S.I.]: Saunders, 1999. 939 p.

COUSINS, D. V.; WILLIAMS, S. N.; REUTER; R., FORSHAW, D.; CHADWICK, B.; COUGHRAN, D.; COLLINS, P.; GALES, N. Tuberculosis in wild seals and characterization of the seal bacillus. Australian Veterinary Journal, v. 70, n. 3, p. 92-97, 1993. 
CROXALL, J. P.; RODWELL, S.; BOYD, I. L.. Entanglement in man made debris of Antarctic fur seals at Bird island, South Georgia. Marine Mammal Science, v. 6, n. 3, p. 221-233, 1990.

DAILEY, M. D. Parasitic diseases, In: DIERAUF, L. A.; GULLAND, F. M. D. (Ed.). Handbook of marine mammal medicine. 2. ed. Boca Raton,FL: CRC Press, 2001. p. 357-379.

DAILEY, M. D.; STROUD, R. Parasites and associated pathology observed in cetaceans stranded along the Oregon coast. Journal of Wildlife Diseases, v. 14, p. 503-511, 1978.

DAILEY, M. D.; WALKER, W. A. Parasitism as a factor in single strandings of southern California cetaceans. Jounal of Parasitology, v. 64, n. 4, p. 593-596, 1978.

DAILEY, M. D.; WALSH, M.; ODELL, D.; CAMPBELL, T. Evidence of prenatal infection in the bottlenose dolphin (Tursiops truncatus) with the lungworm Halocercus lagenorhynchi (Nematoda: Pseudaliidae). Journal of Wildlife Diseases, v. 27, p. 164-165, 1991.

DAOUST, P. -Y., HAINES, D. M.; THORSEN, J.; DUIGNAN, P. J.; GERACI, J. R. Phocine distemper in a harp seal (Phoca groenlandica) from the Gulf of St. Lawrence, Canada. Journal of Wildlife Diseases, v. 29, n. 1, p. 114-117, 1993.

DAVEY, J. T. A revision of the genus Anisakis Dujardin, 1845 (Nematoda: Ascaridata). Journal of Helminthology, v. 45, n. 1, p. 51-72, 1971.

DEGOLLADA, E.; ANDRÉ, M.; ARBELO, M.; FERNÁNDEZ, A. Incidence, pathology and involvement of Nasitrema species odontocete strandings in the Canary Islands. Veterinary Record, v. 150, p. 81-82.

DE GUISE, S.; LAGACÉ, A.; BÉLAND, P. Tumors in St. Lawrence Beluga whales (Delphinapterus leucas). Veterinary Pathology, n. 31, p. 444-449, 1994.

DE LONG, R. L.; GILMARTIN, W. G.; SIMPSON, J. G. Premature births of California sea lions associated with high organochlorine pollutant residue levels. Science, v. 181, p. 1168-1169, 1973.

DELYAMURE, S. F. Helminthofauna of marine mammals. Moscow: Academy of Science of the U.S.S.R., 1955. 522 p.

DENG, M. Q.; PETERSON; R. P.; CLIVER, D. O. First findings of Cryptosporidium and Giardia in California sea lions (Zalophus californianus). Journal of Parasitology, v. 86, p. 490-494, 2000.

DIERAUF, L. A. From fish to fin to flipper: the evolution of marine mammals. In: Handbook of marine mammal medicine: health, disease and rehabilitation. Boca Raton: CRC Press, 1990a. p. 381397. 
DIERAUF, L. A. Marine mammal parasitology. In: . Handbook of marine mammal medicine: health, disease and rehabilitation. Boca Raton, FL: CRC Press, 1990b. p. 89-96.

DIERAUF, L. A. Pinniped forensic, necropsy and tissue collection guide. NOAA Technical Memorandum, NMFS-OPR-94-3, 1994. 80p.

DIERAUF, L. A.; VANDENBROEK, D. J.; ROLETTO, J.; KOSKI, M.; AMAYA, L.; GAGE, L. J. An epizootic of leptospirosis in California sea lions. Journal of the American Veterinary Medical Association, v. 187, n. 11, p. 1145-1148, 1985.

DIERAUF, L. A.; GAGE, L. J. Gross necropsy of cetaceans and pinnipeds. In: DIERAUF, L. A. (Ed.) Handbook of marine mammal medicine: health, disease and rehabilitation. Boca Raton, FL: CRC Press, 1990. p. 285-286.

DOMINGO, M.; VISA, J.; PUMAROLA, M.; MARCO, A. J.; FERRER, L.; RABANAL, R.; KENNEDY, S. Pathologic and Immunocytochemical studies of morbilivirus infection in striped dolphins (Stenella coeruleoalba). Veterinary Pathology, v. 29, p. 1-10, 1992.

DOUGHERTY, E. C. The lungworms (Nematoda: Pseudalidae) of Odontoceti. Part I. Parasitology, v. 36, n. $1 / 2$, p. 80-94, 1944.

DUIGNAN, P. J.; GERACI, J. R.; RAGA, J. A.; CALZADA, N. Pathology of morbilivirus infection in striped dolphins (Stenella coeruleoalba) from Valencia and Murcia, Spain. Canadian Journal of Veterinary Research, v. 56, p. 242-248, 1992.

DUIGNAN, P. J.; HOUSE. C.; GERACI, J. R.; EARLY, G.; COPLAND, H. G.; WALSH, M. T.; BOSSART, G. D.; CRAY, C.; SADOVE, S.; ST. AUBIN, D. J.; MOORE, M. Morbilivirus infection in two species of pilot whales (Globicephala sp.) from the western Atlantic. Marine Mammal Science, v. 11, n. 2, p. 150-162, 1995.

DUIGNAN, P. J.; NIELSEN, O.; HOUSE, C.; KOVACS, K.; DUFFY, N.; EARLY, G.; SADOVE, S.; ST. AUBIN, D. J.; RIMA, B. K.; GERACI, J. R. Epizootiology of morbilivirus infection in harp, hooded, and ringed seals from the Canadian Arctic and western Atlantic. Journal of Wildlife Diseases, v. 33, n. 1, p. 7-19, 1997.

DUIGNAN, P. J. Morbilivirus infections in marine mammals. In: FOWLER, M. E. (Ed.). Zoo and wild animal medicine: current therapy 4. W. B. Saunders Co., 1999. p. 497-501.

DUNGWORTH, D. L. The respiratory system, In: JUBB, K. V. F.; KENNEDY, P. C.; PALMER, N. (Ed.). Pathology of domestic animals. San Diego, CA: Academic Press, 1993. vol. 2. p. 539-699. 
DUNN, J. L. Bacterial and mycotic diseases of cetaceans and pinnipeds, In: DIERAUF, L. A. (Ed.). Handbook of marine mammal medicine: health, disease and rehabilitation. Boca Raton, FL: CRC Press, 1990. p. 73-87.

DUNN, J. L.; BUCK, J. D.; ROBECK, T. R. Bacterial diseases of cetaceans and pinnipeds, In: DIERAUF, L. A.; GULLAND, F. M. D. (Ed.). Handbook of marine mammal medicine. 2. ed. Boca Raton, FL: CRC Press, 2001. p. 309-335.

FORSHAW, D.; PHELPS, G. R. Tuberculosis in a captive colony of pinnipeds. Journal of Wildlife Diseases, v. 27, n. 2, p. 288-295, 1991.

FRANÇA, G. V. Traumatologia médico legal. In: Medicina legal. 5. ed. Rio de Janeiro: Guanabara Koogan, 1998. p. 55-133.

GARELL, D. M. Toxoplasmosis in zoo animals. In: FOWLER, M. E.; MILLER, E. R. (Ed.) Zoo and wild animal medicine: current therapy 4. Philadelphia: W. B. Saunders Co., 1999. p. 131-135.

GERACI, J. R.; SWEENEY, J. C. Medical care of strandlings. In: GERACI, J. R.; ST. AUBIN, D. J. (Ed.). Biology of marine mammals: Insights through strandings. Final Report to the Marine Mammal Commission MMC 77/13. Springfield, Virginia: National Technical Information Services, 1979. p. 264289.

GERACI, J. R.; LOUNSBURY, V. J. Cetaceans - single strandings. In: Marine mammals ashore: A field guide for strandings. Galveston, TE: Texas A \& M Sea Grant Publication, 1993a. p. 71131.

Pinnipeds. In: Marine mammals ashore: A field guide for strandings. Galveston, TE:

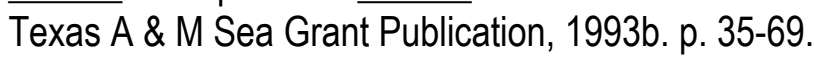

Specimen and Data Collection. In: Marine mammals ashore: A field guide for strandings. Galveston, TE: Texas A \& M Sea Grant Publication, 1993c. p. 175-228.

GERBER, J. A.; ROLETTO, J.; MORGAN, L. E.; SMITH, D. M.; GAGE, L. Findings in pinnipeds stranded along the central and northern California coast, 1984-1990. Journal of Wildlife Diseases, v. 29, p. 423-433, 1993.

GILMARTIN, W. G.; DE LONG, R. L.; SMITH, A. W.; SWEENEY, J. C.; DE LAPPE, B. W.; RISEBOROUGH, R. W.; GRINER, L. A.; DAILEY, M. D.; PEAKAL, D. B. Premature parturition in the californian sea lion. Journal of Wildlife Diseases, v. 12, p. 104-115, 1976. 
GINGERICH, P. D.; HAQ, M.; ZALMOUT, I. S.; KHAN, I. H.; MALKANI, M. S. Origin of whales from early Artiodactyls: Hands and feet of Eocene Protocetidae from Pakistan. Science, v. 293, p. 22392242, 2001.

GLIATTO, J. M.; BRONSON, R. T. Fatal fasting syndrome of obese macaques In: JONES, T. C.; MOHR, U.; HUNT, R. D. (Ed.). Nonhuman primates I. Berlin: Springer-Verlag, 1993. p. 198-202.

GOMERCIC, H.; HUBER, D.; GOMERCIC, V.; VUKOVIC, S.;SKRTIC, D.; GOMERCIC, T.; DOBRANIC, V.; LUCIC, H.; DURAS, M.; CURKOVIC, S.; GOMERCIC, A.; KARDOS, L. Fatty liver and subcutaneous edema in a free-living bottlenose dolphin (Tursiops truncatus, Montagu 1821) from the Adriatic Sea; light- and electron-microscopical study. Veterinarski Arhiv, v. 70, n. 5, p. 259-277, 2000.

GONZALEZ, L.; PATTERSON, I. A.; REID, R. J.; FOSTER, G.; BARBERÁN, M.; BLASCO, J. M.; KENNEDY, S.; HOWIE, F. E.; GODFROID, J.; MACMILLAN, A. P.; SHOCK, A.; BUXTON, D. Chronic meningoencephalitis associated with Brucella sp. infection in live-stranded striped dolphins (Stenella coeruleoalba). Journal of Comparative Pathology, v. 126, p. 147-152, 2002.

GULLAND, F. M. D. Leptospirosis in marine mammals. In: FOWLER, M. E.; MILLER, E. R. (Ed.) Zoo and wild animal medicine: current therapy 4. Philadelphia: W. B. Saunders Co., 1999. p. 496-471.

GULLAND, F. M. D.; KOSKI, M.; LOWENSTINE, L. J.; COLAGROSS, A.; MORGAN, L.; SPRAKER, T. Leptospirosis in California sea lions (Zalophus californianus) stranded along the central California coast, 1981-1994. Journal of Wildlife Diseases, v. 32, n. 4, p. 572-580, 1996.

GULLAND, F. M. D.; LOWENSTINE, L. J.; SPRAKER, T. R. Noninfectious diseases, In: DIERAUF, L. A.; GULLAND, F. M. D. (Ed.). Handbook of marine mammal medicine. 2. ed. Boca Raton, FL: CRC Press, 2001. p. 521-543.

HARTMANN, M. G.; COUPERUS, A. S.; ADDINK, M. J. The diagnosis of by-catch: preliminary results of research in the Netherlands. In: KUIKEN, T. (Ed.). Diagnosis of by-catch in cetaceans. ECS WORKSHOP ON CETACEAN PATHOLOGY, 2., 1994. Proceedings. Montpellier, França. p. 16-23.

HARVELL, C. D.; KIM, K.; BURKHOLDER, J. M.; COLWELL, R. R.; EPSTEIN, P. R.; GRIMES, D. J.; HOFMANN, E. E.; LIPP, E. K.; OSTERHAUS, A. D. M. E.; OVERSTREET, R. M.; PORTER, J. W.; SMITH, G. W.; VASTA, G. R. Emerging marine diseases - Climate links and anthropogenic factors. Science, v. 285, p. 1505-1510, 1999.

HIGGINS, R. Bacteria and fungi of marine mammals: A review. Canadian Veterinary Journal, v. 41, p. 105-116, 2000.

HOLSHUH, H. J.; SHERROD, A. E.; TAYLOR, C. R.; ANDREWS, B. F.; HOWARD, E. B. Toxoplasmosis in a feral northern fur seal. Journal of the American Veterinary Medical Association, v. $187,1229-1230,1985$. 
HOWARD, E. B. (Ed.). Miscellaneous Diseases. In:

diseases, Boca Raton: CRC Press, 1983. vol. 2. p. 163-225.

Pathobiology of marine mammal

HOWARD, E. B.; BRITT, J. O.; MATSUMOTO, G. K.; ITAHARA, R.; NAGANO, C. N. Bacterial diseases. In: HOWARD, E. B. (Ed.). Pathobiology of marine mammal diseases. Boca Raton: CRC Press, 1983a. vol. 1. p. 69-118.

HOWARD, E. B.; BRITT, J. O.; MATSUMOTO, G. K. Parasitic diseases. In: HOWARD, E. B. (Ed.).

Pathobiology of marine mammal diseases. Boca Raton, FL: CRC Press, 1983b. vol. 1. p. 119-232.

IBAMA. Mamíferos aquáticos do Brasil: Plano de Ação. Brasília: Instituto Brasileiro do Meio Ambiente e dos Recursos Naturais Renováveis, 1997. 80 p.

IBAMA. Mamíferos aquáticos do Brasil: Plano de Ação, Versão II. Brasília: Instituto Brasileiro do Meio Ambiente e dos Recursos Naturais Renováveis, 2001. 96 p.

INSKEEP, W. II; GARDINER, C. H.; HARRIS, R. K.; DUBEY, J. P.; GOLDSTON, R. T. Toxoplasmosis in an Atlantic bottlenose dolphin (Tursiops truncatus). Journal of Wildlife Diseases, v. 27, 377-382, 1990.

JARDINE, J. E.; DUBEY, J. P. Congenital toxoplasmosis in an Indo-Pacific bottlenose dolphin (Tursiops aduncus). Journal of Parasitology, v. 88, p. 197-199, 2002.

JEFFERSON, T. A.; LEATHERWOOD, S.; WEBER, M. A. Marine mammals of the world. FAO Species Identification Guide. [S.I.]: United Nations Environment Programme, 1993. 320 p.

JEPSON, P. D.; BENNET, P. M.; ALLCHIN, C. R.; LAW, R. J.; KUIKEN, T.; BAKER, J. R.; ROGAN, E.; KIRKWOOD, J. K. Investigating potential associations between chronic exposure to polychlorinated biphenyls and infectious disease mortality in harbour porpoises from England and Wales. The Science of the Total Environment, v. 243/244, p. 339-348, 1999.

JEPSON, P. D. ; BAKER, J. R.; KUIKEN, T.; SIMPSON, V. R.; KENNEDY, S. BENNET, P. M. Pulmonary pathology of harbour porpoises (Phocoena phocoena) stranded in England and Wales between 1990 and 1996. Veterinary Record, v. 146, p. 721-728, 2000.

JONES, T. C.; HUNT, R. D. (Ed.). The urinary system. In: Veterinary pathology. 5. ed. Philadelphia: Lea \& Febiger, 1983. p. 1443-1502.

JONES, T. C.; HUNT, R. D.; KING, N. W. (Eds.). Cells: death of cells and tissues. In: Veterinary pathology. 6. ed. Baltimore: Williams \& Wilkins, 1996. p. 1-23. 
KELLY, R. W. The liver and biliary system. In: JUBB, K. V. F.; KENNEDY, P. C.; PALMER, N. (Ed.). Pathology of domestic animals. San Diego, CA: Academic Press, 1993. vol. 2. p. 319-406.

KENNEDY, S. Morbilivirus infections in aquatic mammals. Journal of Comparative Pathology, v. 119, p. 201-225, 1998.

KENNEDY-STOSKOPF, S. Viral diseases In: DIERAUF, L. A.; GULLAND, F. M. D. (Ed.). Handbook of marine mammal medicine. 2. ed. Boca Raton: CRC Press, 2001. p. 285-307.

KENNEDY, S.; SMYTH, J. A.; CUSH, P. F.; McALISKEY, M.; McCULLOUGH; RIMA, B. K., Histopathologic and immunocytochemical studies of distemper in harbor porpoises. Veterinary Pathology, v. 28, p. 1-7, 1991.

KRIEG, N. R.; HOLT, J. C. Bergey's manual of systematic bacteriology. Baltimore: Williams \& Wilkins, 1984. vols. 1 e 2. 1599 p.

KUIKEN, T.; SIMPSON, V. R.; ALLCHIN, C. R.; BENNETT, P. M.; CODD, G. A.; HARRIS, E. A.; HOWES, G. J.; KENNEDY, S., KIRKWOOD, J. K.; LAW, R. J.; MERRETT, N. R.; PHILLIPS, S. Mass mortality of common dolphins (Delphinus delphis) in south west England due to incidental capture in fishing gear. Veterinary Record, v. 134, p. 81-89, 1994.

KUIKEN, T. Review of the criteria for the diagnosis of by-catch in cetaceans. In: KUIKEN, T. (Ed.). Diagnosis of by-catch in cetaceans. ECS WORKSHOP ON CETACEAN PATHOLOGY, 2., 1994. Proceedings. Montpellier, França. p. 38-43.

LABER-LAIRD, K. E.; JONIKEN, M. P. LEHNER, N. D. M. Fatal fatty liver-kidney syndrome in obese monkeys. Laboratory Animal Science, v. 37, n. 2, p. 205-209, 1987.

LAMBERTSEN, R. H.; KOHN, B. A.; SUNDBERG, J. P.; BUERGELT, C. D. Genital papillomatosis in sperm whale bulls. Journal of Wildlife Diseases, v. 23, n. 3, p. 361-367, 1987.

LA POINTE, J. M.; DUIGNAN, P. J.; MARCH, A. E.; GULLAND, F. M. D.; BARR, B. C.; NAYDAN, D. K. KANG, D. P.; FARMAN, C.A.; BUREK, K. A.; LOWENSTINE, L. J. Meningoencephalitis due to Sarcocystis neurona-like protozoan in Pacific harbor seals (Phoca vitulina richardsi). Journal of Parasitology, v. 84, p. 1184-1189, 1998.

LEITE, M. C. P. Patologia comparada de Callithrix geoffroyi Humboldt, 1812 (Callitrichidae Primates) mantidos em cativeiro no Centro de Primatologia do Rio de Janeiro. 2001. $206 \mathrm{f}$. Dissertação (Mestrado em Patologia Experimental e Comparada) - Faculdade de Medicina Veterinária e Zootecnia, Universidade de São Paulo, São Paulo, 2001. 
LIPSCOMB, T. P. Pathologic findings in dolphins known to have died from underwater entrapment. In: KUIKEN, T. (Ed.). Diagnosis of by-catch in cetaceans. ECS WORKSHOP ON CETACEAN PATHOLOGY, 2., 1994. Proceedings. Montpellier, França. p. 1- 3.

LIPSCOMB, T. P.; SCHULMAN, F. Y.; MOFFETT, D.; KENNEDY, S. Morbiliviral disease in Atlantic bottlenose dolphins (Tursiops truncatus) from the 1987-1988 epizootic. Journal of Wildlife Diseases, v. 30 , n. 4 , p. 567-571, 1994.

LOWENSTINE, L. J.; OSBORN, K. G. Practical marine mammal microanatomy for pathologists. In: DIERAUF, L. (Ed.) Handbook of marine mammal medicine: health, disease and rehabilitation. Boca Raton, FL: CRC Press, 1990. p. 287-290.

MALUF, N. S. R.; GASSMAN, J. J. Kidneys of the killer whale and significance of reniculism. The Anatomical Record, v. 250, p. 34-44, 1998.

MARIGO, J.; ANDRADE, A. L. V.; ROSAS, F. C. W. Parasitos pulmonares de cetáceos do litoral do Estado do Paraná, Brasil. In: REUNIÓN DE TRABAJO DE ESPECIALISTAS EN MAMÍFEROS ACUÁTICOS DE AMÉRICA DEL SUR, 9., CONGRESO DE SOLAMAC, 3., 2000. Anais. Buenos Aires, Argentina. p. 82.

MARTINEAU, D.; LAGACÉ, A.; MASSÉ, R.; MORIN, M.; BÉLAND, P. Transitional cell carcinoma of the urinary bladder in a beluga whale (Delphinapterus leucas). Canadian Veterinary Journal, v. 26, p. 297302, 1985.

MARTINEAU, D.; LAGACÉ, A.; BÉLAND, P.; HIGGINS, R.; ARMSTRONG, D.; SHUGART, L. R. Pathology of stranded beluga whales (Delphinapterus leucas) from the St. Lawrence Estuary, Québec, Canada. Journal of Comparative Pathology, v. 98, p. 287-311, 1988.

MARTINEAU, D.; DE GUISE, S.; FOURNIER, M.; SHUGART, L.; GIRARD, C.; LAGACÉ, A.; BÉLAND, P. Pathology and toxicology of beluga whales from the St. Lawrence Estuary, Quebec, Canada. Past, present and future. The Science of the Total Environment, v. 154, p. 201-215, 1994.

MEASURES, L. N.; OLSON, M. Giardiasis in pinnipeds from Eastern Canada. Journal of Wildlife Diseases, v. 35, n. 4, p. 779-782, 1999.

MEDWAY, W. Some bacterial and mycotic diseases of marine mammals. Journal of the American Veterinary Medical Association, v. 177, p. 831-834, 1980.

MIGAKI, G. Mycotic diseases in captive animals - a mycopathologic overview. In: MONTALI, R. J.; MIGAKI, G. (Ed.). Pathology of zoo animals. Washington, D.C.: Smithsonian Institution Press, 1980. p. 267-285. 
MIGAKI, G.; JONES, S. R. Mycotic diseases in marine mammals. In: HOWARD, E. B. (Ed.).

Pathobiology of marine mammals diseases. Boca Raton, FL.: CRC Press, 1983. vol. 2. p. 2-27.

MILLER, W. G.; ADAMS, G.; FICHT, T. A.; CHEVILLE, N. F.; PAYEUR, J. P.; HARLEY, D. R.; HOUSE, C.; RIDGWAY, S. H., Brucella-induced abortions and infection in bottlenose dolphins (Tursiops truncatus). Journal of Zoo and Wildlife Medicine, v. 30, n. 1, p. 100-110, 1999.

MOSER, M.; RHINEHART, H. The lungworm, Halocercus spp. (Nematoda: Pseudallidae) in cetaceans from California. Journal of Wildlife Diseases, v. 29, p. 507-508, 1993.

MORIMITSU, T.; NAGAI, T.; IDE, M.; KAWANO, H.; NAICHUU, A.; KOONO, M.; ISHII, A. MasS stranding of Odontoceti caused by parasitogenic eighth cranial neuropathy. Journal of Wildlife Diseases, v. 23, n. 4, p. 586-590, 1987.

OLSON, M.; ROACH, P. D.; STABLER, M.; CHAN, W. Giardiasis in ringed seals from the Western Arctic. Journal of Wildlife Diseases, v. 33, n. 3, p. 646-648, 1997.

O'SHEA, T. J.; HOMER, B. L.; GREINER, E. C.; LAYTON, A. W. Nasitrema sp.-associated encephalitis in a striped dolphin (Stenella coeruleoalba) stranded in the Gulf of Mexico. Journal of Wildlife Diseases, v. 27, n. 4, p. 706-709, 1991.

OTT, P. H.; SECCHI, E. R.; MORENO, I. B.; DANILEWICZ, D.; CRESPO, E. A.; BORDINO, P.; RAMOS, R.; DI BENEDITTO, A. P.; BERTOZZI, C. P.; BASTIDA, R.; ZANELATTO, R.; PEREZ, J.; KINAS, P. Report of the working group on fishery interactions. Latin American Journal of Aquatic Mammals, v. 1, n. 1, p. 55-64, 2002. Suplemento Especial.

PABST, A. D.; ROMMEL, S. A.; McLELLAN, W. A. The functional morphology of marine mammals. In: REYNOLDS III, J. E.; ROMMEL, S. A. (Ed.). Biology of marine mammals. Washington and London: Smithsonian Institution Press, 1999. p. 15-72.

PERRIN, W. F.; DONOVAN, G. P.; BARLOW, J. (Ed.). Gillnets and cetaceans. Cambridge, UK: International Whaling Commission, 1994. 629 p. Suplemento especial 15.

PINEDO M. C.; BARRETO, A. S.; LAMMARDO, M. P.; ANDRADE, A. L. V.; GERACITANO, L.. Northernmost records of the spectacled porpoise, Layard's beaked whale, Commerson's dolphin, and Peale's dolphin in the southwestern Atlantic Ocean. Aquatic Mammals, v. 28, n.1, p. 32-37, 2002.

PRICE, E. The trematode parasite of marine mammals. Proceedings of the United States Natural Museum, v. 81, n. 13, 1932.68 p.

PROPHET, E. B.; MILLS, B.; ARRINGTON, J. B.; SOBIN, L. H. Laboratory methods in histotechnology. Washington: American Registry of Pathology, 1991. 274 p. 
RAMOS, R. M. A.; DI BENEDITTO, A. P. M.; SOUZA, S. M. Bone lesions in Sotalia fluviatilis (Cetacea) as a consequence of entanglement: Case report. Brazilian Journal of Veterinary Research and Animal Science, v. 38, n. 4, p. 192-195, 2001.

REEVES, R. R.; STEWART, B. S.; LEATHERWOOD, S. Subantarctic fur seal (Arctocephalus tropicalis) In: . Seals and sirenians. San Francisco, CA: Sierra Club Books, 1992. p. 90-92.

REIDARSON, T. H.; MC BAIN, J. F.; DALTON, L. M.; RINALDI, M. G. Mycotic diseases. In: DIERAUF, L. A.; GULLAND, F. M. D. (Ed.). Handbook of marine mammal medicine. 2. ed. Boca Raton: CRC Press, 2001. p. 337-355.

RESENDES, A. R.; ALMERIA, S.; DUBEY, J. P.; OBÓN, E.; JUAN-SALLES, C.; DEGOLLADA, E.; ALEGRE, F.; CABEZÓN, O.; PONT, S.; DOMINGO, M. Disseminated toxoplasmosisin a Mediterranean pregnant Risso's dolphin (Grampus griseus) with transplacental fetal infection. Journal of Parasitology, v. 88, n. 5, p. 1029-1032, 2002.

REYES, J. C.; WAEREBEEK, K. V.; CÁRDENAS, J. C.; YÁÑES, J. L. Mesoplodon bahamondi SP. N. (Cetacea, Ziphiidae), a new living beaked whale from the Juan Fernandez Archipelago, Chile. Boletin del Museo de Historia Natural de Chile, v. 45, p. 31-44, 1995.

REYNOLDS III, J. E.; ROMMEL, S. A. (Ed.) Biology of marine mammals. Washington and London: Smithsonian Institution Press, 1999. 599 p.

RIDGWAY, S. H. Homeostasis in the aquatic environment. In: RIDGWAY, S. H. (Ed.). Mammals of the sea: biology and medicine. Springfield, Illinois: Charles C. Thomas, 1972. p. 590-747.

RIDGWAY, S. H.; DAILEY, M. D. Cerebral and cerebellar involvement of trematode parasites in dolphins and their possible role in stranding. Journal of Wildlife Diseases, v. 8, p. 33-43, 1972.

RIEDMANN, M. Adaptations to a marine existence. In: RIEDMANN, M. The pinnipeds: seals, sea lions and walruses. Berkeley: University of California Press, 1990a. p. 1-49.

RIEDMANN, M. Evolution, classification and distribution of pinnipeds. In: RIEDMANN, M. The pinnipeds: seals, sea lions and walruses. Berkeley: University of California Press, 1990b. p. 50-83.

ROMMEL, S. A.; LOWENSTINE, L. J. Gross and microscopic anatomy. In: DIERAUF, L. A.; GULLAND, F. M. D. (Ed.). Handbook of marine mammal medicine. 2. ed. Boca Raton: CRC Press, 2001. p. 129164. 
RUOPPOLO, V.; MARIGO, J.; MOTA, E. F. F.; BERTOZZI, C.; CATÃO-DIAS, J. L. Doença renal policística em golfinho-de-dentes-rugosos, Steno bredanensis (Cetacea: Delphinidae): relato de caso. In: ENCONTRO NACIONAL DE PATOLOGIA VETERINÁRIA (ENAPAVE), 10., 2001. Anais. Pirassununga, São Paulo, Brasil. p. 6.

RUOPPOLO, V.; MARIGO, J.; CATÃO-DIAS, J. L. Creating a marine mammal tissue bank in Brazil. In: REUNIÓN DE TRABAJOS DE ESPECIALISTAS EN MAMIFEROS ACUÁTICOS DE AMÉRICA DEL SUR, 10., CONGRESO DE LA SOCIEDAD LATINOAMERICANA DE ESPECIALISTAS EN MAMÍFEROS ACUÁTICOS (SOLAMAC), 4., 2002. Anais. Valdívia, Chile. p. 113.

RUOPPOLO, MARIGO, J.; CATÃO-DIAS, J. L. Anatomia patológica e parasitologia de golfinhospintados- do- atlântico, Stenella frontalis, capturados acidentalmente em rede de pesca em São Paulo. In: CONGRESSO DA ASSOCIAÇÃO BRASILEIRA DE VETERINÁRIOS DE ANIMAIS SELVAGENS, 6 ., 2002, Anais. Guarapari, Brasil. p. 71.

SÁ, L. R. M. Determinação e caracterização de enfermidades que acometem calitriquídeos e cebídeos (Estudo multidisciplinar). 1999. 174 f. Dissertação (Mestrado em Patologia Experimental e Comparada) - Faculdade de Medicina Veterinária e Zootecnia, Universidade de São Paulo, São Paulo, 1999.

SANTOS, C. P.; ROHDE, K.; RAMOS, R.; DI BENEDITTO, A. P. Helminths of cetaceans on the Southeastern coast of Brazil. Journal of the Helminthological Society of Washington, v. 63, n. 1, p. 149-152, 1996.

SCHWARTZ, D. A.; GEYER, J. Klebsiella and rhinoscleroma. In: CONNOR, D. H.; CHANDLER, F. W.; SCHWARTZ, D. A.; MANZ, H. J.; LACK, E. E. (Ed.). Pathology of infectious diseases. Stanford: Appleton \& Lance, 1997. vol. 1. p. 589-594.

SIEBERT, U.; WÜNSCHMANN, A.; WEISS, R.; FRANK, H.; BENKE, H.; FRESE, K. Post-mortem findings in harbour porpoises (Phocoena phocoena) from the German North and Baltic seas. Journal of Comparative Pathology, v. 124, p. 102-114, 2001.

SIMÕES-LOPES, P. C.; PAULA, G. S.; BOTH, M. C.; XAVIER, F. M.; SCARAMELLO, A. C. First case of lobomycosis in a bottlenose dolphin from Southern Brazil. Marine Mammal Science, v. 9, n. 3, p. 329-331, 1993.

SMITH, A. W.; SKILLING, D. E. Viruses and virus diseases in marine mammals. Journal of the American Veterinary Medical Association, v. 175, n. 9, p. 918-920, 1979.

STANLEY, W. T.; SHAFFER, K. E. Harbor seal (Phoca vitulina) predation on seined salmonids in the lower Clamath river, California. Marine Mammal Science, v. 11, n. 3, p. 376-385, 1995. 
ST. AUBIN, D. J.; DIERAUF, L. A. Stress and marine mammals, In: DIERAUF, L. A.; GULLAND, F. M. D. (Ed.). Handbook of marine mammal medicine. 2. ed. Boca Raton, FL: CRC Press, 2001. p. 253269.

STEWARDSON, C. L.; HEMSLEY, S.; MEYER, M. A.; CANFIELD, P. J.; MAINDONALD, J. H. GrosS and microscopic visceral anatomy of the male Cape fur seal, Arctocephalus pusillus pusillus (Pinnipedia: Otariidae), with reference to organ size and growth. Journal of Anatomy, v. 195, p. 235255, 1999.

STOSKOPF, S. K. Viral diseases in marine mammals. In: DIERAUF, L. A. (Ed.). Handbook of marine mammal medicine: health, disease and rehabilitation. Boca Raton, FL: CRC Press, 1990. p. 97-114.

STROUD, R.; DAILEY, M. D. Parasites and associated pathology observed in pinnipeds stranded along the Oregon coast. Journal of Wildlife Diseases, v. 14, p. 292-298, 1978.

STROUD, R. K.; ROFFE, T. J. Causes of death in marine mammals stranded along the Oregon coast. Journal of Wildlife Diseases, v. 15, p. 91-97, 1979.

SWEENEY, J. C., Common diseases of pinnipeds. Journal of the American Veterinary Medical Association, v. 165, 805-810, 1974.

SWEENEY, J. C.; GILMARTIN, W. G. Survey of diseases in free-living California sea lions. Journal of Wildlife Diseases, v. 10, p. 370-376, 1974.

SWEENEY, J. C.; MIGAKI, G.;VAINIK, P. M.; CANKLIN, R. H. Systemic mycoses in marine mammals. Journal of the American Veterinary Medical Association, v. 169, p. 946-948, 1976.

SWEENEY, J. C.; RIDGWAY, S. H. Common diseases of small cetaceans. Journal of the American Veterinary Medical Association, v. 167, n. 7, p. 533-539, 1975.

TRYLAND, M.; KLEIVANE, L.; ALFREDSSON, A.; KJELD, M.; ARNASON, A.; STUEN, S.; GODFROID, $J$. Evidence of Brucella infection in marine mammals in the North Atlantic Ocean. Veterinary Record, $v$. 144, p. 588-592, 1999.

UNITED NATIONS ENVIRONMENT PROGRAMME (UNEP). Review of Contaminants in Marine Mammals. Nairobi: United Nations Environment Programme. 1991. 23 p.

VAN BRESSEM, M. -F.; VAN WAEREBEEK, K.; PIERARD, G. E.; DESAINTES, C. Genital and lingual warts in small cetaceans from coastal Peru. Diseases of Aquatic Organisms, v. 26, p. 1-10, 1996.

VAN BRESSEM, M. -F.; KASTELEIN; R. A.; FLAMANT; P.; ORTH, G. Cutaneous papillomavirus 
infection in a harbour porpoise (Phocoena phocoena) from the North Sea. Veterinary Record, v. 144, p. 592-593, 1999.

VEDROS, N. A.; SMITH, A. W.; SCHOENWALD, J.; MIGAKI, G.; HUBBARD, R. C. Leptospirosis epizootic among California sea lions. Science, v. 172, p. 1250-1251, 1971.

WADA, K.; HAYAMA, S. I.; NAKAOKA, T.; UNO, H. Interaction between Kuril seals and salmon trap net fishery in the coastal waters of southeastern Hokkaido. Marine Mammal Science, v. 7, n. 1, p. 75-84, 1991.

WICKENS, P. Interactions between South african fur seals and the purse-seine fishery. Marine Mammal Science, v. 10, n. 4, p. 442-457, 1994.

WOODS, R.; COUSINS, D. V.; KIRKWOOD, R.; OBENDORF, D. L. Tuberculosis in a wild Australian fur seal (Arctocephalus pusillus doriferus) from Tasmania. Journal of Wildlife Diseases, v. 31, n. 1, p. 8386, 1995.

YAMAGUTI, S. Acanthocephala. In: Systema Helminthum. New York: Wiley Interscience Publ. Co., 1963. vol. 5.

YOGUI, G. T. Ocorrência de compostos organoclorados (pesticidas e PCBs) em mamíferos marinhos da costa de São Paulo (Brasil) e da Ilha Rei George (Antártica). 2002. 157 f. Dissertação (Mestrado em Ciências, Oceanografia Química e Geológica) - Instituto Oceanográfico, Universidade de São Paulo, São Paulo, 2002. 


\section{ANEXO 1 \\ Procedimento para colheita de material para histopatologia:}

Este texto tem como objetivo auxiliar a descrição e colheita de material para histopatologia e posterior determinação de causa mortis de mamíferos marinhos, assim como a formação de um banco de tecidos para posteriores estudos.

- Tendo o animal a presença de qualquer característica externa anômala, bem como pigmentações, feridas, ferimentos, marcas de rede, cicatrizes ou outras lesões estas devem ser descritas quanto a coloração, relevo e tamanho. Estas descrições devem ser feitas de forma objetiva utilizando-se unidades métricas ou cores convencionais, quando assim for o caso.

- Após a abertura do animal deve-se fazer uma análise geral dos órgãos em suas posições originais, dentro das respectivas cavidades que ocupam. Deve-se observar a coloração dos órgãos, das paredes internas das cavidades, assim como a presença de derrames cavitários (líquidos) e sua descrição quanto à coloração e viscosidade e presença ou não de aderências.

- Feita a retirada dos órgãos passa-se para uma análise individual de cada um deles. Esta análise objetiva a observação de tamanho, consistência e coloração. Frisa-se mais uma vez que estas descrições devem ser feitas de maneira objetiva, obedecendo escalas métricas e cores convencionais.

- Passadas estas etapas deve-se realizar as colheitas para histopatologia. Estas devem ser feitas com bisturi, evitando-se pinçar o fragmento após o corte. Estes fragmentos devem ter de $\mathbf{1}$ a $\mathbf{2} \mathbf{~ c m}^{3}$ para que haja a penetração do fixador e preservação total do tecido. A colheita deve ser feita de forma representativa, ou seja, havendo lesão a amostra deve ser tomada na região de transição entre a lesão e o tecido são, pois assim se conseguirá uma visão histológica das duas regiões. Também devem ser colhidas amostras de órgãos de aparência macroscópica sã, pois estes podem apresentar lesões microscópicas importantes.

- Os fragmentos devem ser colocados em um frasco contendo formol a $\mathbf{1 0 \%}$.

- Obs.: $O$ formol comercial é comumente vendido na concentração de $37-40 \%$. Para obter formol na concentração de $10 \%$, a diluição deve ser de 1:9 (uma parte de formol $37-40 \%$ para nove partes de água).

- O volume de formol no frasco deve ser $\mathbf{1 0}$ vezes maior que o volume das amostras colhidas.

- Identificar as amostras: adicionar ao frasco contendo as amostras um pedaço de papel vegetal com as seguintes informações escritas a lápis: número de campo do animal, assim como espécie, sexo, idade estimada, data e órgãos contidos no frasco, favor preencher esta ficha, suas observações são essenciais ao trabalho.

Obs.: Animais congelados ou em estado de decomposição muito avançado não possibilitam a realização de estudos histopatológicos.

Quaisquer dúvidas ou informações adicionais comunique-se com Valeria Ruoppolo, tel.: (11) 5667-5222 ou através de valijuli@uol.com.br 
Ficha de Necrópsia:

Necroscopista: Data:

No de campo: Espécie: Sexo:

Idade estimada: $\square$ adulto

$\square$ sub-adulto

$\square$ juvenil

$\square$ filhote

Peso: $\mathrm{kg}$

Data do óbito:

Morte: $\square$ encalhe

$\square$ captura acidental

$\square$ fotos:

\section{Informações sobre o encalhe/captura:}

Local:

Data do encalhe:

Data de coleta do exemplar:

Número de animais envolvidos:

\section{Estado da Carcaça:}
$\square$ fresca
$\square$ refrigerada
$\square$ moderadamente decomposta
$\square$ congelada

\section{Medidas da Carcaça:}

Cetáceos:

rostro à comissura caudal:

rostro ao ápice do melão:

$\mathrm{cm}$ $\mathrm{cm}$

rostro ao centro do orifício respiratório: rostro ao centro do ânus: $\mathrm{cm}$

rostro à inserção anterior da nadadeira peitoral: (D) $\mathrm{cm}$ comprimento anterior da nadadeira peitoral:(desde a inserção anterior até a ponta):
(D)
$\mathrm{cm}$
(E) $\mathrm{cm}$

comprimento posterior da nadadeira peitoral (desde a axila até a ponta): (D) $\mathrm{cm}$

(E) $\mathrm{cm}$

largura máxima da nadadeira peitoral: (D) $\mathrm{cm}$

(E) $\mathrm{cm}$ altura da nadadeira dorsal: $\mathrm{cm}$

Pinípedes:

comprimento total: $\mathrm{cm}$ comprimento desde o focinho até o orifício peniano (machos): $\mathrm{cm}$ circunferência na região axilar: $\mathrm{cm}$ comprimento anterior da nadadeira anterior (desde a inserção anterior até a ponta): (D)__ $\quad \mathrm{cm}(\mathrm{E}) \_\mathrm{cm}$ comprimento posterior da nadadeira anterior (desde a axila até a ponta): (D) $\mathrm{cm}$ (E) largura máxima da nadadeira anterior: (D) $\mathrm{cm}$ comprimento anterior da nadadeira posterior (desde a inserção anterior até a ponta): (D) $\mathrm{cm}(\mathrm{E})$ $\mathrm{cm}$
Condição nutricional:
boa
$\square$ regular
$\square$ ruim
caquético 


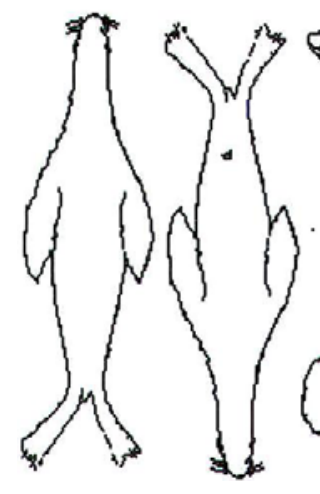

$\leftarrow$ Lesões e cicatrizes $\rightarrow$

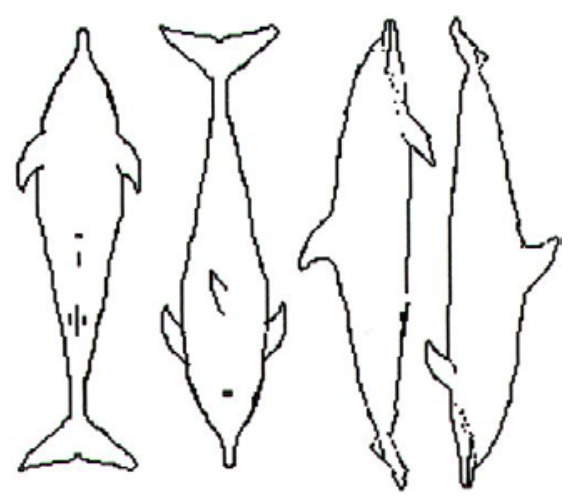

Análise Necroscópica:

Atenção: todos os órgãos devem ser observados em sua coloração, tamanho, consistência e presença ou não de lesões, rupturas de órgãos e derrames cavitários. Os órgãos devem ser amostrados em fragmentos de no máximo $2 \mathrm{~cm}^{3}$ e serem preservados em um volume no mínimo 10 vezes maior de fixador.

Análise externa:

$\square$ lesões externas

Obs.:

Análise dos órgãos in situ:

Região torácica

$\square$ normal $\square$ alterada

Obs.:

Região abdominal

$\square$ normal $\square$ alterada

Obs.:

Análise dos órgãos:

Pele

$\square$ normal $\square$ alterada

Obs.: 
Olhos
$\square$ normais
$\square$ alterados

Obs.:

Boca

$\square$ normal $\square$ alterada

Obs.:

Língua

$\square$ normal

$\square$ alterada

Obs.:

\section{Esôfago}

$\square$ normal

$\square$ alterado $\square$ presença de alimento/vômito

Obs.:
Estômago
$\square$ normal
$\square$ alterado
$\square$ parasitas
Obs.:

Fígado

$\square$ normal $\square$ alterado

Obs.:

Pâncreas

$\square$ normal $\square$ alterado

Obs.: 
Intestinos

$\square$ normais

$\square$ alterados

$\square$ parasitas

Obs.:

Ânus

$\square$ normal $\square$ alterado

Obs.:

Traquéia

$\square$ normal

$\square$ alterada

$\square$ parasitas

Obs.:

Pulmões

$\square$ normais

$\square$ parasitas

$\square$ alterados

Obs.:

\section{Coração}

$\square$ normal $\square$ alterado

Obs.:

Tireóide

$\square$ normal $\square$ alterada

Obs.:

Adrenais

$\square$ normais $\square$ alteradas

Obs.: 
Rins

$\square$ normais $\square$ alterados

Obs.:

Bexiga
$\square$ normal
$\square$ alterada
$\square$ vazia
$\square$ cheia

Obs.:

Testículos/ovários

$\square$ normais $\square$ alterados

Obs.:

Útero

$\square$ normal $\quad \square$ alterado $\square$ gravídico

$\square$ feto $\rightarrow$ peso: __

comprimento:

Obs.:

Pênis/vagina

$\square$ normal $\square$ alterado

Obs.:

Glândulas mamárias

$\square$ normais $\square$ alteradas

$\square$ lactantes $\square$ amostra de leite

Obs.: 
Baço

$\square$ normal $\quad \square$ alterado

Obs.:

Linfonodos

$\square$ normais

$\square$ alterados

Obs.:

Sistema Nervoso

$\square$ normal $\quad \square$ alterado $\quad \square$ não examinado

Obs.:

Esqueleto

$\square$ normal

$\square$ alterado

Obs.:

Amostras colhidas: $\quad \square$ pele $\quad \square$ olhos $\quad \square$ sistema nervoso

$\square$ esqueleto (fragmento de osso) $\square$ gordura $\square$ músculo $\square$ língua

$\square$ esôfago $\square$ estômago $\square$ fígado $\square$ pâncreas

$\square$ intestinos $\quad \square$ ânus $\quad \square$ traquéia $\quad \square$ pulmões

$\square$ coração $\square$ adrenais $\square$ rins $\square$ bexiga

$\square$ ovário/testículos $\square$ útero $\square$ pênis/vagina

$\square$ glândulas mamárias $\quad \square$ tireóide $\quad \square$ baço

$\square$ linfonodos $\square$ timo $\square$ parasitas

Quaisquer dúvidas ou informações comunique-se com Valeria Ruoppolo telefone (11)5667-5222, ou pelo e-mail: valijuli@uol.com.br 


\begin{abstract}
ANEXO 2
Lista de Diagnósticos Finais

Organização dos diagnósticos segundo a localização, condição ou alteração. Junho de 1991

(Richard J. Montali, National Zoological Park, Washington, E.U.A.)

Na maioria dos casos, o diagnóstico final pode ser dado nesta ordem:

(órgão) (condição) (estado de alteração) (intensidade de alteração)
\end{abstract}

Fígado, hepatite, aguda, severa

Usualmente, as alterações localizadas em órgãos específicos ou componentes específicos podem ser colocados diretamente depois da condição:

Rim, nefrite, intersticial, crônica, discreta

Alguns órgãos requerem que a localização seja adicionada diretamente depois dele:

Osso, úmero, fratura, composta

Os órgãos que requerem localização são: vasos sangüíneos, osso, articulação, linfonodo e intestinos (delgado ou grosso).

Quando a localização é desconhecida, acrescentar o termo "localização não específica" (LNE).

Quando a lesão afeta múltiplos sítios do mesmo tecido, por exemplo linfonodo, usar:

$$
\text { Linfonodo, múltiplos sítios }
$$

Quando partes dos estômagos de ruminantes são listados, o termo inicial pode ser "Estômago", seguido do compartimento específico ou da alteração observada:

Estômago, ruminite, ulcerativa

Estômago, abomaso, corpo estranho

Tanto o órgão como o diagnóstico devem ser sempre mencionados no singular:

Pulmão, granuloma, múltiplo - e não Pulmões, granulomas.

Modificações podem ser adicionadas quando estiverem relacionadas com quantidade, como acima (múltiplo), ou das localizações (Pele, mordidas, múltiplos sítios). 


\section{Lista de Causas de Morte \\ (ou dos principais achados que contribuem com a causa de morte) \\ Junho de 1991}

Os termos eutanásia e perinatal são utilizados na frente das causas de morte, como se fossem condições adicionais reportadas.

Perinatal, indeterminada, ausência de carcaça ou

Eutanásia, neoplasia, adenocarcinoma.

Cardiovascular

Circulatório

Congênito

Cutâneo

Digestivo (incluindo fígado, vesícula biliar e pâncreas)

Endócrino

Estresse

Eutanásia

Hematopoiético (incluindo baço, linfonodo, medula óssea)

latrogênico, procedimentos

Imunológico

Indeterminado, autólise

Indeterminado, ausência de carcaça

Infeccioso, agente indeterminado

Infeccioso, bacteriano

Infeccioso, fúngico

Infeccioso, vírus

Metabólico

Músculo-esquelético

Não evidente

Neoplasia

Nutricional

Parasitismo

Perinatal

Peritôneo

Agente físico

Reprodutivo

Respiratório

Sensitivo (incluindo olhos, orelhas, narinas)

Sistema nervoso central

Síndrome

Toxicidade

Trauma, acidental

Trauma, auto traumatismo

Trauma, indeterminado

Trauma, maternal

Trauma, paternal

Trauma, predador

Trauma, recinto

Trauma, vandalismo

Urinário 


\begin{tabular}{|c|c|c|c|c|c|c|c|c|c|}
\hline $\mathrm{N}^{\circ}$ de origem & Espécie & Sexo & Idade & Peso & Captura & Encalhe & Local & Órgãos & Data \\
\hline $\mathrm{IPeC} 050$ & Sotalia fluviatilis & fêmea & neonato & $15 \mathrm{~kg}$ & $\mathrm{X}$ & & $\mathrm{PR}$ & baço & 15-dez-97 \\
\hline $\mathrm{IPeC} 054$ & Sotalia fluviatilis & macho & $\mathrm{ad}$ & $78,5 \mathrm{~kg}$ & $\mathrm{X}$ & & PR & pulmão, figado, rim & 26-jan-98 \\
\hline $\mathrm{IPeC} 055$ & P. blainvillei & macho & juv & $11,7 \mathrm{~kg}$ & $\mathrm{X}$ & & SP-S & pulmão, fígado, rim, bexiga & 31-jan-98 \\
\hline $\mathrm{IPeC} 056$ & P. blainvillei & macho & juv & $12,5 \mathrm{~kg}$ & 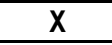 & & SP-S & pulmão, fígado, rim, bexiga & 31-jan-98 \\
\hline $\mathrm{IPeC} 057$ & Stenella frontalis & macho & juv & $40 \mathrm{~kg}$ & & $X$ & PR & bexiga & 14-fev-98 \\
\hline $\mathrm{IPeC} 061$ & Sotalia fluviatilis & fêmea & ad & $85,5 \mathrm{~kg}$ & & $\mathrm{X}$ & PR & rim, pulmão d, fígado & 23-mar-98 \\
\hline $\mathrm{IPeC} 065$ & P. blainvillei & macho & juv & $11,5 \mathrm{~kg}$ & $\mathrm{X}$ & & PR & bexiga, pâncreas, pulmão & 03-jun-98 \\
\hline $\mathrm{IPeC} 076$ & Sotalia fluviatilis & fêmea & $\mathrm{ad}$ & $63 \mathrm{~kg}$ & $\mathrm{X}$ & & $\mathrm{PR}$ & pulmão, fígado, baço, rim & 06 -ago-98 \\
\hline IPeC 085 & Sotalia fluviatilis & macho & $<1$ ano & N.R. & $\mathbf{x}$ & & PR & língua, figado, olho, coração, pulmão & 20 -ago-98 \\
\hline $\mathrm{IPeC} 089$ & Delphinus capensis & macho & $\mathrm{ad}$ & N.R. & & $\mathrm{X}$ & PR & figado, coração, rim, pulmão & 31-ago-98 \\
\hline $\mathrm{IPeC} 093$ & Sotalia fluviatilis & macho & $<1$ ano & $43 \mathrm{~kg}$ & & $\mathrm{X}$ & PR & pulmão, coração, rim, fígado & 08-set-98 \\
\hline $\mathrm{IPeC} 095$ & P. blainvillei & macho & $\mathrm{ad}$ & $16 \mathrm{~kg}$ & $\mathbf{X}$ & & SP-S & coração, pulmão, fígado, baço, pâncreas, rim, bexiga, adrenal & 12-set-98 \\
\hline $\mathrm{IPeC} 096$ & P. blainvillei & macho & juv & $10,2 \mathrm{~kg}$ & $\mathbf{X}$ & & SP-S & coração, pulmão, rim, fígado & 12-set-98 \\
\hline $\mathrm{IPeC} 097$ & P. blainvillei & fêmea & juv & $10,7 \mathrm{~kg}$ & $\mathrm{X}$ & & SP-S & pulmão, baço, rim, fígado & 12-set-98 \\
\hline $\mathrm{IPeC} 103$ & P. blainvillei & fêmea & juv & $11 \mathrm{~kg}$ & $\mathbf{X}$ & & $\mathrm{PR}$ & rim, coração, pulmão, adrenal & 30-set-98 \\
\hline $\mathrm{IPeC} 106$ & P. blainvillei & fêmea & ad & $17,5 \mathrm{~kg}$ & $\mathbf{X}$ & & SP-S & coração, fígado, pulmão, rim, adrenal & 07-out-98 \\
\hline $\mathrm{IPeC} 107$ & P. blainvillei & macho & juv & $14 \mathrm{~kg}$ & $\mathbf{X}$ & & SP-S & fígado, rim, adrenal & 07-out-98 \\
\hline $\mathrm{IPeC} 108$ & P. blainvillei & fêmea & juv & $12,5 \mathrm{~kg}$ & $\mathrm{X}$ & & SP-S & adrenal & $07-$ out-98 \\
\hline IPeC 109 & Delphinus capensis & macho & $\mathrm{ad}$ & $103,5 \mathrm{~kg}$ & & $x$ & PR & coração, pulmão, fígado, rim, adrenal & 10-out-98 \\
\hline IPeC 110 & P. blainvillei & macho & neonato & $3,5 \mathrm{~kg}$ & & $\mathrm{X}$ & $\mathrm{PR}$ & coração, pulmão, figado, adrenal & 31-out-98 \\
\hline $\mathrm{IPeC} 111$ & P. blainvillei & macho & juv & $12,7 \mathrm{~kg}$ & $\mathrm{X}$ & & SP-S & coração, pulmão, fígado, adrenal & 28-out-98 \\
\hline $\mathrm{IPeC} 112$ & P. blainvillei & macho & juv & $11 \mathrm{~kg}$ & $\mathrm{X}$ & & SP-S & coração, pulmão, fígado, adrenal & 28-out-98 \\
\hline $\operatorname{IPeC} 113$ & P. blainvillei & macho & juv & $12,7 \mathrm{~kg}$ & $x$ & & SP-S & coração, pulmão, fígado, adrenal & 28-out-98 \\
\hline $\mathrm{IPeC} 114$ & P. blainvillei & fêmea & juv & $15 \mathrm{~kg}$ & & $x$ & PR & coração, rim, pulmão & 17-nov-98 \\
\hline $\mathrm{IPeC} 116$ & Sotalia fluviatilis & fêmea & $<1$ ano & $42 \mathrm{~kg}$ & $\mathrm{X}$ & & PR & coração, pulmão, fígado, rim & 29-nov-98 \\
\hline $\mathrm{IPeC} 118$ & P. blainvillei & N.R. & juv & $9 \mathrm{~kg}$ & & $\mathrm{X}$ & PR & coração, pulmão, fígado, adrenal & 01-dez-98 \\
\hline IPeC 119 & P. blainvillei & macho & ad & $15,5 \mathrm{~kg}$ & $\mathrm{X}$ & & $\mathrm{PR}$ & coração, pulmão, fígado, rim, pâncreas & 15-dez-98 \\
\hline $\mathrm{IPeC} 120$ & Sotalia fluviatilis & macho & $\mathrm{ad}$ & $101 \mathrm{~kg}$ & & $x$ & PR & bexiga & 15-dez-98 \\
\hline $\mathrm{IPeC} 135$ & Stenella frontalis & macho & $\mathrm{ad}$ & $82 \mathrm{~kg}$ & & $\mathrm{X}$ & PR & coração, pulmão, fígado & N.R. \\
\hline MO-CA 153 & P. blainvillei & fêmea & $\mathrm{ad}$ & $26 \mathrm{~kg}$ & $\bar{X}$ & & RS-S & pele, olho, gord, fíg, pâncreas, int, pulmão, coração, rim, bex, útero, baço, gm, língua & 21-mai-98 \\
\hline MO-CA 154 & P. blainvillei & macho & ad & $28,6 \mathrm{~kg}$ & $\mathbf{X}$ & & RS- S & coração, pulmão, rim, fígado, pâncreas & 23-mai-98 \\
\hline MO-CA 155 & P. blainvillei & macho & $\mathrm{ad}$ & $29,6 \mathrm{~kg}$ & $\mathbf{X}$ & & RS-S & coração, pulmão, rim, fígado, pâncreas & 23-mai-98 \\
\hline MO-CA 156 & P. blainvillei & macho & ad & $28,6 \mathrm{~kg}$ & $\mathbf{X}$ & & RS- S & coração, pulmão, rim, fígado, pâncreas & 23-mai-98 \\
\hline MO-CA 176 & P. blainvillei & macho & $\mathrm{ad}$ & $26,7 \mathrm{~kg}$ & $\bar{X}$ & & RS-S & pele, gordura, músculo, fígado, pâncreas, int, pulmão, coração, rim, baço & 25 -jun-98 \\
\hline MO-CA 177 & P. blainvillei & macho & $\mathrm{ad}$ & $26 \mathrm{~kg}$ & $\bar{X}$ & & RS-S & pele, gordura, músculo, fígado, pâncreas, int, pulmão, coração, rim, baço & 25-jun-98 \\
\hline MO-CA 178 & P. blainvillei & macho & $\mathrm{ad}$ & $23,3 \mathrm{~kg}$ & $\mathbf{X}$ & & RS- S & pele, gordura, músculo, fígado, pâncreas, int, pulmão, coração, rim, baço & 25 -jun-98 \\
\hline MO-CA 179 & P. blainvillei & macho & juv & $17,5 \mathrm{~kg}$ & $\mathbf{X}$ & & RS-S & pele, gordura, músculo, fígado, pâncreas, int, pulmão, coração, rim, baço & 25-jun-98 \\
\hline MO-CA 180 & P. blainvillei & macho & juv & $19,6 \mathrm{~kg}$ & $\mathbf{X}$ & & RS-S & pele, gordura, músculo, fígado, pâncreas, int, pulmão, coração, rim, baço & 25 -jun-98 \\
\hline MO-CA 193 & P. blainvillei & fêmea & juv & $20,6 \mathrm{~kg}$ & $\mathbf{X}$ & & RS-S & pele, gordura, músculo, fígado, pâncreas, int, pulmão, coração, rim, baço & 18-ago-98 \\
\hline
\end{tabular}




\begin{tabular}{|c|c|c|c|c|c|c|c|c|c|}
\hline $\mathrm{N}^{0}$ de origem & Espécie & Sexo & Idade & Peso & Captura & Encalhe & Local & Órgãos & Data \\
\hline MO-CA 194 & P. blainvillei & fêmea & juv & $29,5 \mathrm{~kg}$ & $\mathrm{X}$ & & RS- $S$ & pele, gordura, músculo, fígado, pâncreas, int, pulmão, coração, rim, baço & 18-ago-98 \\
\hline MO-CA 195 & P. blainvillei & macho & $\mathrm{ad}$ & $31,5 \mathrm{~kg}$ & $\mathbf{X}$ & & RS- $S$ & pele, gordura, músculo, fígado, pâncreas, int, pulmão, coração, rim, baço & 18-ago-98 \\
\hline MO-CA 196 & P. blainvillei & fêmea & juv & $22,8 \mathrm{~kg}$ & $\mathbf{X}$ & & RS- $S$ & pele, gordura, músculo, fígado, pâncreas, int, pulmão, coração, rim, baço & 13-out-99 \\
\hline MO-CA 199 & P. blainvillei & macho & juv & $19,1 \mathrm{~kg}$ & $\mathbf{X}$ & & RS-S & pele, gordura, músculo, fígado, pâncreas, int, pulmão, coração, rim, baço & 20-out-99 \\
\hline MO-CA 200 & P. blainvillei & macho & juv & $24,2 \mathrm{~kg}$ & $\mathrm{X}$ & & RS-S & pele, gordura, músculo, fígado, pâncreas, int, pulmão, coração, rim, baço & 20-out-99 \\
\hline MO-CA 201 & P. blainvillei & fêmea & juv & $21,4 \mathrm{~kg}$ & $\mathbf{X}$ & & RS- $S$ & pele, gord, músc, fíg, pâncr, int, traquéia, pulm, cor, rim, bex, baço, líng, timo, estôm & 22-out-99 \\
\hline MO-CA 202 & P. blainvillei & macho & juv & $24,6 \mathrm{~kg}$ & $\mathbf{X}$ & & RS- $S$ & pele, gord, músc, líng, esôf, est, cor, traq, pulm, rim, fíg, pâncr, int, baço, adr, bex, timo & 25-out-99 \\
\hline MO-CA 203 & P. blainvillei & macho & juv & $14,4 \mathrm{~kg}$ & $\mathbf{X}$ & & RS- $S$ & pele, gord, músc, líng, esôf, est, cor, traq, pulm, rim, fíg, pâncr, int, baço, adr, bex, timo & 30-out-99 \\
\hline MO-CA 204 & P. blainvillei & macho & juv & $17 \mathrm{~kg}$ & $\mathbf{X}$ & & RS- $S$ & pele, gord, músc, líng, esôf, est, cor, traq, pulm, rim, fíg, pâncr, int, baço, adr, bex, pênis & 30-out-99 \\
\hline MO-CA 205 & P. blainvillei & macho & juv & $21,4 \mathrm{~kg}$ & $\mathbf{X}$ & & RS- $S$ & pele, gord, músc, líng, esôf, est, cor, traq, pulm, rim, fíg, pâncr, int, baço, adr, bex, pênis & 06-nov-99 \\
\hline MO-CA 206 & P. blainvillei & fêmea & $\mathrm{ad}$ & $40,6 \mathrm{~kg}$ & $\mathbf{X}$ & & RS- $S$ & pele, gord, músc, líng, esôf, est, cor, traq, pulm, rim, fíg, pâncr, int, baço, adr, bexiga & 08-nov-99 \\
\hline MO-CA 207 & P. blainvillei & macho & juv & $18 \mathrm{~kg}$ & $\mathbf{X}$ & & RS-S & pele, gord, músc, líng, esôf, est, cor, traq, pulm, rim, fíg, pâncr, int, baço, adr, bex, linf & 29-nov-99 \\
\hline MO-CA 208 & P. blainvillei & macho & $\mathrm{ad}$ & $27,8 \mathrm{~kg}$ & $\mathbf{X}$ & & RS-S & pele, gord, músc, líng, esôf, est, cor, traq, pulm, rim, fíg, pâncr, int, baço, bex, diafragma & 29-nov-99 \\
\hline MO-CA 209 & P. blainvillei & fêmea & juv & $20 \mathrm{~kg}$ & $\mathbf{X}$ & & RS-S & pele, gord, músc, líng, esôf, est, cor, traq, pulm, rim, fíg, pâncr, int, baço, adr, bex, diafrag, linf & 29-nov-99 \\
\hline MO-CA 210 & P. blainvillei & macho & juv & $21,8 \mathrm{~kg}$ & $\mathbf{X}$ & & RS- $S$ & pele, gord, músc, líng, esôf, est, cor, traq, pulm, rim, figg, pâncr, int, baço, adr, bex, test, diafrag, linf & 01-dez-99 \\
\hline MO-CA 211 & P. blainvillei & macho & juv & $19 \mathrm{~kg}$ & $\mathbf{X}$ & & RS-S & pele, gord, músc, líng, esôf, est, cor, traq, pulm, rim, fíg, pâncr, int, baço, adr, bex, test, diafrag & 01-dez-99 \\
\hline MO-CA 212 & P. blainvillei & fêmea & juv & $16,6 \mathrm{~kg}$ & $\mathbf{X}$ & & RS- $S$ & pele, gord, músc, líng, esôf, est, cor, traq, pulm, rim, fíg, pâncr, int, baço, adr, bex, linf, diafrag & 01-dez-99 \\
\hline MO-CA 213 & P. blainvillei & fêmea & juv & $11,6 \mathrm{~kg}$ & $\mathbf{X}$ & & RS-S & pele, gord, músc, líng, esôf, est, cor, traq, pulm, rim, fíg, pâncr, int, baço, adr, bex, linf, diafrag & 01-dez-99 \\
\hline MO-CA 214 & P. blainvillei & macho & juv & $23 \mathrm{~kg}$ & $\bar{X}$ & & RS- S & pele, gord, músc, líng, esôf, est, cor, traq, pulm, rim, fíg, pâncr, int, baço, adr, bexiga & 01-dez-99 \\
\hline MO-CA 215 & P. blainvillei & macho & N. R. & $26 \mathrm{~kg}$ & $\mathbf{X}$ & & RS- $S$ & pele, gord, músc, líng, esôf, est, cor, traq, pulm, rim, fíg, pâncr, int, baço, adr, bex, linf, diafrag & 09-dez-99 \\
\hline MO-CA 216 & P. blainvillei & macho & juv & $19,8 \mathrm{~kg}$ & $\mathbf{X}$ & & RS- $S$ & pele, gord, músc, líng, esôf, est, cor, traq, pulm, rim, fíg, pâncr, int, baço, adr, bex, linf, diafrag & 18-dez-99 \\
\hline MO-CA 217 & P. blainvillei & fêmea & $\mathrm{ad}$ & $29 \mathrm{~kg}$ & $\mathbf{X}$ & & RS-S & pele, gord, músc, líng, esôf, est, cor, traq, pulm, rim, fíg, pâncr, int, baço, adr, bex, linf, diafrag & 21-dez-99 \\
\hline MO-CA 218 & P. blainvillei & fêmea & juv & $17,1 \mathrm{~kg}$ & $\mathbf{X}$ & & RS-S & pele, gord, músc, líng, esôf, est, cor, traq, pulm, rim, fíg, pâncr, int, baço, adr, bex, linf, diafrag & 06-jan-00 \\
\hline MO-CA 222 & P. blainvillei & fêmea & juv & $21,8 \mathrm{~kg}$ & $\mathbf{X}$ & & RS- $S$ & coração, estômago, fígado, músculo, pâncreas, pele, rim & \\
\hline MO-CA 223 & P. blainvillei & macho & $\mathrm{ad}$ & $22,9 \mathrm{~kg}$ & $\mathbf{X}$ & & RS-S & baço, bexiga, figado, linfonodo, pâncreas, pele & \\
\hline MO-CA 224 & P. blainvillei & fêmea & juv & $22 \mathrm{~kg}$ & $\mathbf{X}$ & & RS- S & gord, músc, líng, esôf, est, cor, traq, pulm, rim, fíg, pâncr, int, baço, adr, bex, útero, timo & 08 -ago-00 \\
\hline MO-CA 226 & P. blainvillei & macho & juv & $16,6 \mathrm{~kg}$ & $\mathbf{X}$ & & RS-S & pele, gord, músc, líng, esôf, est, cor, traq, pulm, rim, fíg, pâncr, int, baço, adr, bexiga & 19-ago-00 \\
\hline MO-CA 229 & P. blainvillei & macho & N.R. & $24,5 \mathrm{~kg}$ & $\mathbf{X}$ & & RS-S & pele, gord, músc, líng, esôf, est, cor, traq, pulm, rim, fíg, pâncr, int, baço, adr, bex, baço, paras, tireóide & 01-set-00 \\
\hline MO-CA 232 & P. blainvillei & fêmea & juv & $20 \mathrm{~kg}$ & $\mathbf{X}$ & & RS-S & pele, gord, músc, líng, esôf, est, cor, traq, pulm, rim, fíg, pâncr, int, baço, adr, bexiga & 10-out-00 \\
\hline MO-CA 233 & P. blainvillei & macho & $\mathrm{ad}$ & $27 \mathrm{~kg}$ & $\mathbf{X}$ & & RS- $S$ & pele, gord, músc, líng, esôf, est, cor, traq, pulm, rim, fíg, pâncr, int, baço, adr, bexiga & 10-out-00 \\
\hline MO-CA 239 & P. blainvillei & fêmea & N.R. & N.R. & $\mathbf{X}$ & & RS-S & adr, baço, bex, cor, eso, est, fíg, int, líng, músc, pânc, pele, pulm, rim, traq & N.R. \\
\hline MO-CA 240 & P. blainvillei & N.R. & N.R. & N.R. & $\mathbf{X}$ & & RS- $S$ & baço, bex, cor, esôfago, est, fíg, int, líng, músculo, pâncreas, pele, pulmão, rim & N.R. \\
\hline MO-CA 248 & P. blainvillei & macho & N.R. & $24,6 \mathrm{~kg}$ & $\mathbf{X}$ & & RS- $S$ & adr, baço, cor, esôfago, fíg, int, líng, músc, pâncreas, pele, pênis, pulm, rim, traquéia & 22-mai-01 \\
\hline $\mathrm{MO}$ & Tursiops truncatus & macho & $\mathrm{ad}$ & N.R. & & $\mathbf{X}$ & RS-S & coração, estômago, fígado, músculo, pele, pulmão, rim, bexiga & jan-02 \\
\hline CRAM 003 & B. acutorostrata & fêmea & juv & N.R. & & $\mathrm{X}$ & RS-S & pele, gord, músc, líng, esôf, est, cor, traq, pulm, rim, fíg, pâncr, int, baço, adr, bex, linfs, útero & 15-jul-99 \\
\hline CRAM 196 & P. blainvillei & fêmea & juv & $18,5 \mathrm{~kg}$ & & reabilit & RS- $S$ & pele, olho, fígado, pâncreas, int, pulmão, coração, rim, snc & 14-out-98 \\
\hline \multirow[t]{2}{*}{ CRAM 267} & Otaria flavescens & macho & juv & $32 \mathrm{~kg}$ & & reabilit & RS-S & \multirow{2}{*}{$\begin{array}{l}\text { snc, músc, lín, esôf, est, fíg, pâncr, int, traq, cor, rim, bex, test, pênis } \\
\text { coração, linfonodo, baço, pâncreas, rim, pulmão, intestino, adrenais, bexiga }\end{array}$} & 05-set-99 \\
\hline & & & & & & & & & \\
\hline CRAM 319 & A. australis & macho & filhote & $7,9 \mathrm{~kg}$ & & reabilit & RS-S & músc, líng, esôf, est, fíg, pâncr, int, traq, pulm, cor, rim, bex, test, pênis, baço, linf & 06-jul-99 \\
\hline CRAM 340 & A. tropicalis & fêmea & juv & $9,8 \mathrm{~kg}$ & & reabilit & RS-S & músc, líng, esôf, est, fíg, pâncr, int, traq, pulm, cor, adrs, rim, bex, ovário, útero, vag, baço, linf & 02-set-99 \\
\hline CRAM 346 & A. australis & macho & juv & $17 \mathrm{~kg}$ & & reabilit & RS- $S$ & snc, músc, líng, esôf, est, fíg, pâncr, int, traq, pulm, cor, adrs, rim, bex, test, pênis, baço, linf & 01-out-99 \\
\hline CRAM 354 & A. australis & macho & juv & $12 \mathrm{~kg}$ & & reabilit & RS-S & músc, líng, esôf, est, fíg, pâncr, int, traq, pulm, cor, rim, bex, test, pênis, baço, linf & 02-set-99 \\
\hline
\end{tabular}




\begin{tabular}{|c|c|c|c|c|c|c|c|c|c|}
\hline $\mathrm{N}^{0}$ de origem & Espécie & Sexo & Idade & Peso & Captura & Encalhe & Local & Órgãos & Data \\
\hline CRAM 356 & A. australis & fêmea & juv & $11,8 \mathrm{~kg}$ & & reabilit & RS- $S$ & coração, pulmão, estômago, figado, rim, baço, ovário & 01-set-99 \\
\hline CRAM 362 & A. australis & macho & juv & $11,6 \mathrm{~kg}$ & & reabilit & RS- $S$ & snc, músc, líng, esôf, est, fíg, pâncr, int, traq, pulm, cor, rim, bex, test, baço, linfonodo & 24-set-99 \\
\hline CRAM 381 & P. blainvillei & macho & neonato & $3,3 \mathrm{~kg}$ & & reabilit & RS- $S$ & pele, gord, músc, líng, esôf, est, fíg, pâncr, int, traq, pulm, cor, adrs, rim, bex, baço, linf & 25-nov-99 \\
\hline CRAM 411 & A. australis & macho & filhote & $5,5 \mathrm{~kg}$ & & reabilit & RS- $S$ & músc, líng, esôf, est, fíg, int, traq, pulm, cor, adrs, rim, bex,test, pênis, baço, linfonodo & 16-mai-00 \\
\hline CRAM 413 & A. australis & macho & juv & $10 \mathrm{~kg}$ & & reabilit & RS- $S$ & músc, líng, esôf, est, fíg, pânc, int, traq, pulm, cor, adrs, rim, bex, test, pênis, baço, linf SM e mesentérico & 14-jun-00 \\
\hline CRAM 539 & Arctocephalus sp. & fêmea & filhote & $6 \mathrm{~kg}$ & & reabilit & RS- $\mathrm{S}$ & snc, músc, líng, esôf, est, fíg, pâncr, int, traq, pulm, cor, rim, bex, ov, út, baço, linfonodo & 10 -out- 00 \\
\hline CRAM 540 & Otaria flavescens & macho & $\mathrm{ad}$ & $380 \mathrm{~kg}$ & & $\mathrm{X}$ & RS- $S$ & músc, líng, esôf, est, fíg, pâncr, int, traq, pulm, cor, adr, rim, bex, baço, linfonodo & 01-out-00 \\
\hline CRAM 559 & A. australis & fêmea & filhote & $7,8 \mathrm{~kg}$ & & reabilit & RS- $S$ & músc, líng, esôf, est, fíg, pânc, int, traq, pulm, cor, adrs, rim, bex, ovário, út, vag, baço, linf & $16-$ nov-00 \\
\hline CRAM 561 & A. australis & fêmea & filhote & $5 \mathrm{~kg}$ & & reabilit & RS- $S$ & músc, líng, esôf, est, fíg, pânc, int, traq, pulm, cor, adrs, rim, bex, ovário, út, baço, linf, diaf, medula & 18-nov-00 \\
\hline CRAM 642 & P. blainvillei & fêmea & neonato & $5,2 \mathrm{~kg}$ & & reabilit & RS-S & adrenal, bex, cérebro, coração, esôfago, fíg, int, músculo, pânc, pele, pulmão, traquéia & 05-nov-01 \\
\hline CRAM & L. carcinophagus & fêmea & juv & $72,5 \mathrm{~kg}$ & & $\mathrm{X}$ & RS- $S$ & gordura, músculo, língua, fígado, pâncreas, pulmão, coração, rim, baço & 29-jun-98 \\
\hline CRAM s $/ n^{0}$ & A. australis & fêmea & filhote & $7,8 \mathrm{~kg}$ & & $\mathrm{X}$ & RS-S & adr, baço, bex, cor, diafr, eso, est, fíg, intest, linf, líng, músc, út, ovário, pânc, pulm, rim, traq & $11 / j \mathrm{ju} / 01$ \\
\hline PAP-004 & A. australis & macho & juv & $15 \mathrm{~kg}$ & & $\bar{x}$ & SP-S & fígado, pâncreas, int, pulm, cor, adr, rim, bex, testíc, tir, baço, linf, paras, tireóide, timo & 25 -jul-98 \\
\hline PA-131 & Sotalia fluviatilis & macho & $\mathrm{ad}$ & $92 \mathrm{~kg}$ & & $\mathbf{X}$ & SP-S & pele, gordura, estômago, fígado, int, pulmão, coração, rim, baço, linfonodo & 31-dez-98 \\
\hline PA-132 & P. blainvillei & fêmea & ad & $19,2 \mathrm{~kg}$ & & $\mathbf{X}$ & SP-S & est, fíg, pâncreas, int, pulmão, rim, bex, ovário, útero, tir, baço, linfonodo & 16-jun-99 \\
\hline CEEMAM 002 & P. blainvillei & fêmea & neonato & N.R. & & $\mathrm{X}$ & SP-C & coração, figado, pulmão, rim & $24-a b r-97$ \\
\hline CEEMAM 004 & Steno bredanensis & macho & $\mathrm{ad}$ & N.R. & & $\mathbf{X}$ & SP-C & pulmão, rim, fígado & 11-mai-97 \\
\hline CEEMAM 009 & P. blainvillei & macho & juv & $12,8 \mathrm{~kg}$ & & $\bar{X}$ & SP-C & coração, fígado, intestino, linfonodo, músculo esquelético, olho, pele, pulmão, rim, testículo & 18-jul-97 \\
\hline CEEMAM 010 & Tursiops truncatus & macho & juv & N.R. & & $\mathbf{X}$ & SP-C & baço ou linfonodo, estômago, fígado, intestino, medula, pele, pulmão, rim & 25 -jul-97 \\
\hline CEEMAM 021 & Stenella frontalis & macho & juv & N.R. & & $\bar{X}$ & SP-C & baço, coração, fígado, linfonodo, músculo esquelético, pele, pulmão, rim & 20-mai-98 \\
\hline CEEMAM 064 & Sotalia fluviatilis & macho & filhote & $31,4 \mathrm{~kg}$ & & $\mathbf{X}$ & SP-C & $\begin{array}{l}\text { língua, esôfago, fígado, pâncreas, int, pulmão, cor, adr, rim, bexiga } \\
\text { testículo, baço, tireóide, linfonodo, pele, gordura, músculo, olho, osso }\end{array}$ & 18-jul-99 \\
\hline CEEMAM 083 & P. blainvillei & fêmea & $\mathrm{ad}$ & N.R. & & $\mathbf{X}$ & SP-C & fígado, músculo, pele, rim & 26-jan-00 \\
\hline CEEMAM 090 & Kogia breviceps & fêmea & $\mathrm{ad}$ & N.R. & & $\mathrm{X}$ & SP-C & olho, coração, pulmão, fígado, rim, músculo & $11-$ jul-00 \\
\hline CEEMAM 111 & P. blainvillei & macho & juv & $12 \mathrm{~kg}$ & $\mathbf{X}$ & & SP-C & snc, olho, pele, gord, esôf, cor, adr, pâncr, est, int, fíg, rim, pulm, bex, testíc, linf mes, tireóide & 30 -ago-00 \\
\hline DELPH-01 & Sotalia fluviatilis & macho & $\mathrm{ad}$ & $90 \mathrm{~kg}$ & & $\bar{X}$ & SP-C & fígado e pulmão & $07-a b r-00$ \\
\hline CB-01 & P. blainvillei & macho & $\overline{a d}$ & N.R. & $\bar{X}$ & & $\overline{S P-C}$ & testículo & 08 -ago-98 \\
\hline CB-04 & P. blainvillei & macho & juv & N.R. & $\mathbf{X}$ & & SP-C & bexiga, intestino, pênis, testículos & 02-jul-99 \\
\hline CB-05 & P. blainvillei & macho & $\mathrm{ad}$ & N.R. & $\mathbf{X}$ & & SP-C & pele, gordura, músculo, melão, saco aéreo, testículo & 10-jul-99 \\
\hline CB-06 & P. blainvillei & macho & juv & N.R. & $\mathrm{x}$ & & SP-C & pele, pênis, testículo & $10-$ fev-00 \\
\hline CB-09 & P. blainvillei & fêmea & juv & N.R. & $\mathbf{X}$ & & SP-C & ovário & 11-mai-00 \\
\hline CB-10 & P. blainvillei & macho & juv & N.R. & $\mathrm{x}$ & & SP-C & rim, testículo & $01-j u l-00$ \\
\hline CB-11 & P. blainvillei & fêmea & $\mathrm{ad}$ & N.R. & $\mathbf{X}$ & & SP-C & ovário, feto com Projeto BioPesca & 01 -ago-00 \\
\hline \multirow[t]{2}{*}{ CB-12 } & P. blainvillei & fêmea & $\mathrm{ad}$ & $21 \mathrm{~kg}$ & $\mathbf{X}$ & & SP-C & \multirow{2}{*}{$\begin{array}{l}\text { pele, gord, olhos, snc, músc, líng, esôf, fíg, pâncr, int, traq, pulm, cor, } \\
\text { adrs, rim, bexiga, ovário, útero, tir, baço, linfonodo }\end{array}$} & 19-ago-00 \\
\hline & & & & & & & & & \\
\hline CB-13 & P. blainvillei & macho & juv & $15 \mathrm{~kg}$ & $\mathbf{X}$ & & SP-C & todos & 03-ago-01 \\
\hline CB-14 & P. blainvillei & macho & ad & $20,9 \mathrm{~kg}$ & $\mathbf{X}$ & & SP-C & todos & 09-nov-01 \\
\hline CB-15 & P. blainvillei & macho & neonato & $3 \mathrm{~kg}$ & $\mathbf{X}$ & & SP-C & todos & 23-nov-01 \\
\hline CB-16 & P. blainvillei & fêmea & $\mathrm{ad}$ & $22 \mathrm{~kg}$ & $\mathbf{X}$ & & SP-C & snc, olho, língua, coração, pulmão, esôf, est, fígado, rim, pâncr, baço,int,adrs,útero,ovs,vag & 05-dez-01 \\
\hline CB-17 & P. blainvillei & macho & juv & $16 \mathrm{~kg}$ & $\mathbf{X}$ & & SP-C & todos & $25-a b r-02$ \\
\hline CB-28 & Tursiops truncatus & fêmea & $\mathrm{ad}$ & N.R. & $\mathbf{X}$ & & SP-C & pele, gord, músc, líng, fíg, pâncr, int, pulm, cor, rim, ovário, útero, baço, linf, bexiga & 23/jan/01 \\
\hline CB-29 & Stenella frontalis & macho & $\mathrm{ad}$ & $84 \mathrm{~kg}$ & $\mathbf{X}$ & & SP-C & todos & $12 / \mathrm{fev} / 01$ \\
\hline
\end{tabular}




\begin{tabular}{|c|c|c|c|c|c|c|c|c|c|}
\hline $\mathrm{N}^{0}$ de origem & Espécie & Sexo & Idade & Peso & Captura & Encalhe & Local & Órgãos & Data \\
\hline CB-30 & Stenella frontalis & macho & $\mathrm{ad}$ & $110 \mathrm{~kg}$ & $\mathrm{X}$ & & SP-C & todos & $12 / \mathrm{fev} / 01$ \\
\hline CB-25 & Steno bredanensis & macho & $\mathrm{ad}$ & N.R. & & $\mathrm{X}$ & SP-C & pele, olho, snc, gord, músc, líng, est, fíg, pâncr, int, traq, pulm, & 23 -ago-00 \\
\hline & & & & & & & & cor, adrs, rim, bex, pênis, tir, baço, linf & \\
\hline CB-26 & P. blainvillei & fêmea & neonato & $2,85 \mathrm{~kg}$ & & reabilit & SP-C & todos & 25-nov-00 \\
\hline CB-31 & P. blainvillei & macho & juv & $8,2 \mathrm{~kg}$ & $\mathrm{X}$ & & SP-C & todos & 14-mai-01 \\
\hline CB-33 & Sotalia fluviatilis & macho & $\mathrm{ad}$ & N.R. & & $\mathrm{X}$ & SP-S & medula esp, músc, olho, ling, fig, pâncr, int, pulm, rim, bex, testic, baço, linf, diafragma & 20 -out- 00 \\
\hline RPC 01/029 & L. weddellii & fêmea & juv & $75,8 \mathrm{~kg}$ & $\mathrm{X}$ & & ANT & todos, exceto tireóide, paratiróide, hipófise, olho & 20 -nov-00 \\
\hline RPC 01/246 & A. tropicalis & macho & $\mathrm{ad}$ & $60 \mathrm{~kg}$ & & $\mathrm{X}$ & SP-C & snc, músc, esôf, est, fíg, pâncr, int, traq, pulm, cor, adrs, rins, tir, baço, linf & 06-set-01 \\
\hline ZOOSAO & E. jubatus & fêmea & $\mathrm{ad}$ & N.R. & & cativeiro & $\mathrm{SP}$ & coração, pulmão, estômago, fígado, rim, intestino, baço & $22-\mathrm{fev}-98$ \\
\hline ZOOSAO & A. tropicalis & macho & $\mathrm{ad}$ & $44 \mathrm{~kg}$ & & reabilit & PR-N & pele, osso, gordura, músc, figado, pâncr, pulmão, cor, adr, rim, bex, baço, linf & 15-set-98 \\
\hline ZOOSAO-1 & A. tropicalis & fêmea & $\mathrm{ad}$ & $39 \mathrm{~kg}$ & & reabilit & SP-C & coração, pulmão, fígado, rim, baço, língua, músculo & 09-jan-99 \\
\hline ZOOSAO-2 & A. tropicalis & macho & $\mathrm{ad}$ & $90 \mathrm{~kg}$ & & reabilit & SP-C & língua, coração, esôfago, pulmão, rim, fígado, baço, intestino, tireóide & 09-jan-99 \\
\hline ZOOSAO-3 & Otaria flavescens & macho & neonato & $13,1 \mathrm{~kg}$ & & cativeiro & $\mathrm{SP}$ & todos & 29-jan-02 \\
\hline CGR & Stenella longirostris & macho & filhote & N.R. & & $\mathrm{X}$ & FN-PE & todos, exceto pâncreas & $20-a b r-00$ \\
\hline UNMP 08-97 & A. australis & fêmea & filhote & $8,5 \mathrm{~kg}$ & & reabilit & AR-N & coração, pulmão, traquéia, fígado, baço, rim, est, linfonodo, adrenais, intest, pâncreas & 15-abr-97 \\
\hline UNMP 17-97 & A. australis & macho & juv & N.R. & & reabilit & AR- N & pulmão, coração, fígado, rim, baço, testículo, pâncreas, bexiga, linfonodo, intest, adrenal & 29-ago-97 \\
\hline UNMP & Kogia breviceps & fêmea & $\mathrm{ad}$ & N.R. & & $\mathrm{X}$ & AR- $N$ & pulmão, baço, rim, fígado, adrenais, ovário, útero, glândula mamária & 29-ago-97 \\
\hline UNMP & Kogia breviceps & fêmea & juv & N.R. & & reabilit & AR- N & $\begin{array}{l}\text { pele, pericárdio, medula, traquéia, músculo, esôfago, estômago, fígado } \\
\text { coração, linfonodo, baço, pâncreas, rim, pulmão, intestino, adrenais, bexiga }\end{array}$ & 01-set-97 \\
\hline UNMP & P. blainvillei & macho & N.R. & N.R. & & $\mathrm{X}$ & AR-N & coração, pulmão, rim, estômago, intestino, pâncreas, fígado & 05-jan-98 \\
\hline UNMP 01-98 & P. blainvillei & macho & juv & $8,7 \mathrm{~kg}$ & & reabilit & AR- N & baço, timo, pâncreas, intestino, rim, fígado, pulmão, coração, traquéia, estômago, adrs & 13-jan-98 \\
\hline UNMP & P. blainvillei & fêmea & juv & $18 \mathrm{~kg}$ & & $\mathrm{X}$ & AR- N & fígado, pâncreas, rim, pulmão, intestino, estômago, traquéia & 15-jan-98 \\
\hline AQ SANTOS & P. blainvillei & macho & N.R. & N.R. & N.R. & N.R. & $\mathrm{SP}-\mathrm{C}$ & coração, fígado, intestino, pele, pênis, pulmão, rim & 22-out-96 \\
\hline AQ SANTOS & Steno bredanensis & macho & filhote & N.R. & & reabilit & SP-C & adrenal, coração, digestivo, figado, intestino, linfonodo, pele, pulmão, rim & 13-jan-97 \\
\hline AQ SANTOS & A. australis & fêmea & N.R. & N.R. & & reabilit & SP-C & adr, baço, cor, digestivo, fíg, int, linf, med cervical, pânc, pele, pulm, rim, SNC & nov/00 \\
\hline$A Q-02-00$ & A. australis & macho & juv & $13 \mathrm{~kg}$ & & $\mathrm{X}$ & SP-C & snc, olho, cor, adr, pâncr, est, int, fíg, rim, pulm, bex, testíc, linf mes e med, tireóide, baço & 02-ago-00 \\
\hline$A Q-03-00$ & A. tropicalis & macho & $\mathrm{ad}$ & $50 \mathrm{~kg}$ & & $\mathbf{X}$ & SP-C & snc, olho, cor, adr, est, int, fíg, rim, pulm, bex, testíc, linf mes e med, tireóide, baço & 24 -ago-00 \\
\hline$A Q-04-00$ & A. tropicalis & macho & juv & $27,4 \mathrm{~kg}$ & & $\mathrm{X}$ & SP-C & snc, cor, pulm, adr, pâncr, est, int, fíg, rim, bex, testíc, linf mes e med, tireóide, baço & 27 -set-00 \\
\hline FUNDAMAR & Stenella frontalis & fêmea & $\mathrm{ad}$ & $90 \mathrm{~kg}$ & & $\bar{X}$ & SP-N & pele, gord, músc, baço, pâncreas, rim, ovário, bexiga & 12-mar-99 \\
\hline FUNDAMAR & A. tropicalis & macho & $\mathrm{ad}$ & caquexia & & $\mathbf{X}$ & SP-N & pulmão, coração, estômago, pâncreas, rim, adrenal, fígado, intestino, bexiga & 13-jul-00 \\
\hline FUNDAMAR 097 & Kogia simus & macho & $\mathrm{ad}$ & N.R. & & $\mathrm{X}$ & SP-N & estômago, fígado, pâncreas, pulmão, rim, testículo & 25/jun/02 \\
\hline AQ UBAT & P. blainvillei & fêmea & neonato & N.R. & & $\bar{X}$ & SP-N & cerebelo, cérebro, coração, fígado, intestino, pulmão, rim & 16-nov-01 \\
\hline \multicolumn{10}{|l|}{ GEMARS } \\
\hline GEM 0286 & Tursiops truncatus & fêmea & $\mathrm{ad}$ & N.R. & & $\mathrm{X}$ & RS- $\mathrm{N}$ & coração & 21 -jun-98 \\
\hline GEM 0524 & P. blainvillei & macho & juv & $17,4 \mathrm{~kg}$ & $\bar{X}$ & & RS- $N$ & coração, pulmão, fígado, rim, pâncreas & 09-jul-98 \\
\hline GEM 0526 & A. australis & macho & juv & N.R. & & $\bar{X}$ & RS- $N$ & coração, fígado, rim & 09-jul-98 \\
\hline GEM 0528 & P. blainvillei & fêmea & & $19,4 \mathrm{~kg}$ & $\mathbf{X}$ & & RS- $N$ & coração, fígado, rim & 11-jul-98 \\
\hline GEM 0529 & P. blainvillei & fêmea & juv & $14,4 \mathrm{~kg}$ & $\mathrm{X}$ & & RS- N & coração, pulmão, fígado, rim, pâncreas & 11-jul-98 \\
\hline GEM 0531 & P. blainvillei & fêmea & $\mathrm{ad}$ & $25,5 \mathrm{~kg}$ & $\mathbf{X}$ & & RS- N & coração, pulmão, fígado, rim, pâncreas & 11-jul-98 \\
\hline GEM 0532 & P. blainvillei & macho & juv & $18,5 \mathrm{~kg}$ & $\mathbf{X}$ & & RS- N & coração, pulmão, fígado, rim, pâncreas & 11-jul-98 \\
\hline GEM 0533 & P. blainvillei & macho & juv & $14,7 \mathrm{~kg}$ & $\bar{X}$ & & RS- $N$ & coração, pulmão, fígado, rim & 31 -ago-98 \\
\hline GEM 0548 & P. blainvillei & fêmea & $\mathrm{ad}$ & $40 \mathrm{~kg}$ & $\bar{X}$ & & RS- $N$ & coração, pulmão, fígado, rim & 14-ago-99 \\
\hline
\end{tabular}




\begin{tabular}{|c|c|c|c|c|c|c|c|c|c|}
\hline $\mathrm{N}^{0}$ de origem & Espécie & Sexo & Idade & Peso & Captura & Encalhe & Local & Órgãos & Data \\
\hline GEM 0592 & S. coeruleoalba & macho & $\mathrm{ad}$ & $131 \mathrm{~kg}$ & $\mathrm{X}$ & & RS- $N$ & coração, pulmão, baço, rim & 26-dez-99 \\
\hline GEM 0596 & P. blainvillei & fêmea & juv & $16,9 \mathrm{~kg}$ & $\mathbf{X}$ & & RS- $N$ & coração, pulmão, fígado, rim & 27-jan-00 \\
\hline GEM 0599 & Stenella frontalis & fêmea & $\mathrm{ad}$ & $88 \mathrm{~kg}$ & & $\mathrm{X}$ & RS- $N$ & coração, pulmão (lesão), rim & 08-fev-00 \\
\hline GEM 0634 & P. blainvillei & macho & neonato & $4 \mathrm{~kg}$ & $\mathbf{X}$ & & RS- $N$ & pulmão, fígado, rim & $27-$ fev- 00 \\
\hline GEM 0635 & P. blainvillei & fêmea & N. R. & N.R. & & $\mathrm{X}$ & RS- $\mathrm{N}$ & coração, pulmão, fígado, rim & 10-jun-00 \\
\hline GEM 0656 & A. australis & macho & juv & $9,5 \mathrm{~kg}$ & & $\mathbf{X}$ & RS- $N$ & coração, pulmão, fígado, rim, intestino, linfonodo, baço & 10-jun-00 \\
\hline GEM 0657 & A. australis & fêmea & juv & $8,5 \mathrm{~kg}$ & & $\mathbf{X}$ & RS- $N$ & coração, pulmão, fígado, rim, intestino, baço & 11 -jun-00 \\
\hline GEM 0662 & A. australis & fêmea & juv & $7 \mathrm{~kg}$ & & $\mathbf{X}$ & RS- $N$ & coração, pulmão, fígado, rim, intestino & 11-jun-00 \\
\hline GEM 0663 & A. australis & fêmea & juv & $9 \mathrm{~kg}$ & & $\mathrm{X}$ & RS- $N$ & coração, pulmão, fígado, rim, intestino & 11-jun-00 \\
\hline GEM 0664 & A. australis & fêmea & juv & $8,5 \mathrm{~kg}$ & & $\mathrm{X}$ & RS- $N$ & coração, pulmão, fígado, intestino & 08-jul-00 \\
\hline GEM 0665 & A. australis & macho & juv & $12,75 \mathrm{~kg}$ & & $\mathbf{X}$ & RS- $N$ & língua, coração, pulmão, fíg, rim, intestino (parasita), baço, glândula ou ovário & 08-jul-00 \\
\hline GEM 0672 & A. australis & macho & juv & N.R. & & $\mathbf{X}$ & RS- $N$ & pulmão, fígado, rim, intestino, baço & 09-jul-00 \\
\hline GEM 0675 & A. australis & macho & juv & $12 \mathrm{~kg}$ & & $\mathbf{X}$ & RS- $N$ & coração, pulmão, fígado, rim, intestino & 09-jul-00 \\
\hline GEM 0691 & A. australis & macho & juv & $9,25 \mathrm{~kg}$ & & $\mathrm{x}$ & RS- $N$ & coração, pulmão, intestino, glândula & 09-jul-00 \\
\hline GEM 0743 & A. australis & fêmea & N.R. & N. R. & & $\mathrm{X}$ & RS- $N$ & coração, pulmão, rim & 27 -ago-00 \\
\hline GEM 0745 & P. blainvillei & fêmea & $\mathrm{ad}$ & $23,1 \mathrm{~kg}$ & $\mathrm{X}$ & & RS- $N$ & coração, pulmão, rim & 01-nov-00 \\
\hline GEM 0747 & P. blainvillei & fêmea & juv & $19,3 \mathrm{~kg}$ & $\mathbf{X}$ & & RS- $N$ & pulmão, fígado, rim & 17-nov-00 \\
\hline GEM 0748 & P. blainvillei & fêmea & $\mathrm{ad}$ & $33,3 \mathrm{~kg}$ & $\mathbf{X}$ & & RS- $N$ & pulmão, fígado, rim & $17-$ nov-00 \\
\hline GEM 0749 & P. blainvillei & macho & $\mathrm{ad}$ & $29 \mathrm{~kg}$ & $\mathbf{X}$ & & RS- $N$ & pulmão, fígado, rim & 17-nov-00 \\
\hline GEM 0750 & P. blainvillei & macho & $\mathrm{ad}$ & $25 \mathrm{~kg}$ & $\mathbf{X}$ & & RS- $N$ & pulmão, fígado, rim & 23-nov-00 \\
\hline GEM 0751 & P. blainvillei & fêmea & N.R. & $22,5 \mathrm{~kg}$ & $\mathbf{X}$ & & RS- $N$ & pulmão, fígado, rim & N.R. \\
\hline GEM 0752 & P. blainvillei & fêmea & $\mathrm{ad}$ & $24 \mathrm{~kg}$ & $\mathrm{X}$ & & RS- $N$ & pulmão, fígado, rim & 23-nov-00 \\
\hline GEM 0753 & P. blainvillei & fêmea & $\mathrm{ad}$ & $29 \mathrm{~kg}$ & $\mathbf{X}$ & & RS- $N$ & pulmão, figado, rim & 23 -nov-00 \\
\hline GEM 0773 & P. blainvillei & N.R. & neonato & $5,9 \mathrm{~kg}$ & & vivo & RS- $N$ & coração, figado, intestino, pulmão, traquéia & N.R. \\
\hline GEM 0774 & P. blainvillei & macho & juv & $10,9 \mathrm{~kg}$ & & vivo & RS- $N$ & adrenal, coração, figado, intestino, língua, pele, pulmão, rim, vaso sanguíneo & N.R. \\
\hline GEM 0795 & Stenella clymene & fêmea & $\mathrm{ad}$ & $71,3 \mathrm{~kg}$ & & $\mathbf{X}$ & RS- $N$ & snc, coração, pulmão, traquéia, fígado, rim, bex, linfonodo, aorta, intest, língua, pâncreas, baço & 09-abr-01 \\
\hline GEM 0797 & P. blainvillei & macho & neonato & $4,5 \mathrm{~kg}$ & & vivo & RS- $N$ & coração, intestino, língua, medula, pele, rim & N.R. \\
\hline GEM 0805 & A. australis & fêmea & filhote & $7,7 \mathrm{~kg}$ & & $\mathrm{X}$ & RS- $N$ & pâncreas, pulmão & N.R. \\
\hline GEM 0807 & A. australis & macho & juv & $12,5 \mathrm{~kg}$ & & $\mathbf{X}$ & RS- $N$ & snc, língua, coração, pulmão, traq, fígado, rim, linfonodo, vaso sang, intest, baço, bex, adr, diaf & $27 / 05 / 01$ \\
\hline GEM 0808 & P. blainvillei & fêmea & N. R. & $21,6 \mathrm{~kg}$ & $\mathbf{X}$ & & RS- $N$ & baço, coração, esôfago, fígado, intestino, medula, pâncreas, pulmão, rim, traquéia & N.R. \\
\hline GEM 0811 & Eubalaena australis & macho & filhote & N.R. & & $\mathbf{X}$ & RS- $N$ & coração, pênis, parasitas & N.R. \\
\hline GEM 0812 & Otaria flavescens & macho & juv & $150 \mathrm{~kg}$ & & $\mathrm{X}$ & RS- $N$ & pele, olho, snc, língua, coração, traq, pulm, fíg, rim, linf, vaso sang, est, intest, baço, pâncr, diaf & 08-jan-02 \\
\hline GEM 0813 & Otaria flavescens & macho & juv & $25 \mathrm{~kg}$ & & $\mathbf{X}$ & RS- $N$ & coração, pulmão, esôfago, intestino, baço, rim, linfonodo, vaso sangüíneo, paras & 12-jan-02 \\
\hline GEM 0814 & P. blainvillei & fêmea & juv & N. R. & & $\mathbf{X}$ & RS- $N$ & adr, baço, cerebelo, coração, fíg, int, med cervical, pâncreas, pele, pulmão, rim, traq, vaso sg & N.R. \\
\hline GEM 0816 & Tursiops truncatus & macho & $\mathrm{ad}$ & N.R. & & $\mathbf{X}$ & RS- $N$ & pulmão & N.R. \\
\hline GEM 0818 & P. blainvillei & macho & $\mathrm{ad}$ & $26,3 \mathrm{~kg}$ & $\mathbf{X}$ & & RS- $N$ & bexiga, coração, fígado, intestino, medula, pâncreas, pulmão, rim & N.R. \\
\hline
\end{tabular}




\begin{tabular}{|c|c|c|c|c|c|c|c|c|c|}
\hline $\mathrm{N}^{0}$ de origem & Espécie & Sexo & Idade & Peso & Captura & Encalhe & Local & Órgãos & Data \\
\hline \multirow[t]{2}{*}{ GEM 0820} & Tursiops truncatus & macho & $\mathrm{ad}$ & N.R. & & $\mathrm{X}$ & RS- N & \multirow{2}{*}{$\begin{array}{c}\text { baço, cerebelo, coração, estômago, fígado, intest, linfonodo, medula, olho, pâncreas } \\
\text { pênis, pulmão, rim, parasitas }\end{array}$} & N.R. \\
\hline & & & & & & & & & N.R. \\
\hline GEM 0821 & M. novaeangliae & fêmea & filhote & N.R. & & $\mathrm{X}$ & RS- N & estômago, linfonodo, pele & N.R. \\
\hline GEM 0823 & Stenella frontalis & fêmea & $\mathrm{ad}$ & N.R. & & $\mathrm{x}$ & RS- N & coracão, intestino, pulmão, rim & N.R. \\
\hline
\end{tabular}

$\begin{array}{rr}\text { TOTAL } 197 & \text { Cetáceos } 152 \\ & \text { Pinípedes: } 45\end{array}$

\begin{tabular}{l} 
Legenda: \\
Ad: adulto \\
CT: comprimento total \\
Juv: juvenil \\
N. R.: não reportado/ não realizado \\
reabilit: reabilitação \\
\hline
\end{tabular}

\begin{tabular}{|l|}
\hline Abreviação dos locais de encalhe \\
e captura acidental em redes de pesca: \\
ANT: Antártica \\
AR- N: Litoral norte da Argentina \\
FN: Fernando de Noronha \\
PR: Litoral do Paraná \\
RS- N: Litoral norte do Rio Grande do Sul \\
RS- S: Litoral sul do Rio Grande do Sul \\
SP: São Paulo \\
SP- C: Litoral central de São Paulo \\
SP- N: Litoral norte de São Paulo \\
SP- S: Litoral sul de São Paulo \\
\hline
\end{tabular}

